Central Washington University

ScholarWorks@CWU

Spring 2019

\title{
Defining historical earthquake rupture parameters and proposed slip distributions through tsunami modeling in south-central Chile
}

Alexander Dolcimascolo

Central Washington University, adolcimascolo31@gmail.com

Follow this and additional works at: https://digitalcommons.cwu.edu/etd

Part of the Geology Commons, Geophysics and Seismology Commons, and the Numerical Analysis and Computation Commons

\section{Recommended Citation}

Dolcimascolo, Alexander, "Defining historical earthquake rupture parameters and proposed slip distributions through tsunami modeling in south-central Chile" (2019). All Master's Theses. 1200.

https://digitalcommons.cwu.edu/etd/1200

This Thesis is brought to you for free and open access by the Master's Theses at ScholarWorks@CWU. It has been accepted for inclusion in All Master's Theses by an authorized administrator of ScholarWorks@CWU. For more information, please contact scholarworks@cwu.edu. 


\title{
DEFINING HISTORICAL EARTHQUAKE RUPTURE PARAMETERS AND PROPOSED SLIP DISTRIBUTIONS THROUGH TSUNAMI MODELING IN SOUTH-CENTRAL CHILE
}

\author{
A Thesis \\ Presented to \\ The Graduate Faculty \\ Central Washington University
}

\author{
In Partial Fulfillment \\ of the Requirements for the Degree \\ Master of Science \\ Geological Sciences
}

by

Alexander Ryan Dolcimascolo

May 2019 


\title{
CENTRAL WASHINGTON UNIVERSITY
}

\author{
Graduate Studies
}

We hereby approve the thesis of

\section{Alexander Ryan Dolcimascolo}

Candidate for the degree of Master of Science

APPROVED FOR THE GRADUATE FACULTY

Dr. Breanyn MacInnes, Committee Chair

Dr. Lisa Ely

Dr. Walter Szeliga

Dean of Graduate Studies 


\begin{abstract}
DEFINING HISTORICAL EARTHQUAKE RUPTURE PARAMETERS AND PROPOSED SLIP DISTRIBUTIONS THROUGH TSUNAMI MODELING IN SOUTH-CENTRAL CHILE
\end{abstract}

by

Alexander Ryan Dolcimascolo

May 2019

Reliable tsunami early warning forecasts rely on accurate initial modeling conditions and interpretations of subduction zone behavior in a multi-century perspective. GPS and seismologic data were introduced this past century to study rupture dynamics in detail, however limited information is known about ruptures that pre-date the $20^{\text {th }}$ century. I propose a methodology that uses statistics to better understand these pre-20 $20^{\text {th }}$ century ruptures. This methodology applies the historical and geologic tsunami record as a means to select a suite of tsunami simulations from earthquake source solutions. I chose south-central Chile $\left(46^{\circ} \mathrm{S}\right.$ to $\left.30^{\circ} \mathrm{S}\right)$ to test this new methodology; it has an extensive earthquake historical record at 47 different coastal sites, some of which date to the $16^{\text {th }}$ century. Between 1570 and 1960, this region experienced at least 17 tsunamigenic earthquakes. In addition to evaluating possible source solutions for these earthquakes, my methodology also allows the test of whether subducted fracture zones, like the Mocha fracture zone (MFZ) in south-central Chile, controls rupture propagation (as previously hypothesized). For this research, I used GeoClaw, a numerical tsunami modeling code, to simulate 423 forward-modeled $\mathrm{M}_{\mathrm{w}}$ 
8.7 - 9.5 earthquake scenarios with stochastic, variable slip distributions. I used Akaike's Information Criterion (AIC) to identify significant earthquake parameters $\left(\mathrm{M}_{\mathrm{w}}\right.$ and slip location) of 17 events by statistically selecting source models that had similar simulated wave heights to known observations in the historic and geologic record. For example, I concluded from AIC that the 1960 event was a $M_{w} 9.3$ rupture with high slip concentration $(\sim 30 \mathrm{~m})$ at $\sim 39-40^{\circ} \mathrm{S}$, and the 1730 event was a $\mathrm{M}_{\mathrm{w}} 9.3$ rupture with shallow maximum slip at $\sim 36^{\circ} \mathrm{S}$; both solutions support the MFZ hypothesis. The AIC results generally agree with previously estimated magnitudes within the literature and were validated by using root mean square error RMSE values. I produced high resolution maps at three coastal sites with well-known tsunami observations for further refinement of potential rupture scenarios. Defining historical rupture characteristics gives insight regarding temporal and spatial variabilities of locking zones. This information may be useful for predicting future near-field tsunami wave heights for particularly vulnerable coastal regions. 


\section{ACKNOWLEDGMENTS}

Before I get into my more personal acknowledgments, I first want to acknowledge the Central Washington University School of Graduate Studies and Research for providing me with my graduate assistantships for the past two years. Also, I would like to acknowledge the National Science Foundation for providing funding to this research with grant EAR-1624542 awarded to Dr. Lisa Ely and Dr. Breanyn MacInnes.

Now, I would like to give a big thank you to my advisor, Bre, for her guidance during the process of completing this project. I especially would like to acknowledge her patience and encouragement when it came to teaching me how to model tsunamis this is a skill I am very grateful to have learned and one that I am very excited to apply towards my career. I could not have asked for a better advisor.

I would also like to thank my "co-advisor," Walter, for teaching me how to fish, rather than just giving me a fish. I now have an understanding of how to code in Python, which will prove to be useful when I enter the workforce. Also, thanks for talking sports with me whenever I needed a break from this project.

Additionally, my final committee member, Lisa, has been a tremendous help to me throughout this project - especially when it came to learning about the tsunami historical record of Chile. Traveling to Chile with you and the rest of the field team was a wonderful experience I will never forget. With that said, I'd also want to acknowledge Pachi for her absolutely extraordinary cooking during our field season. Those were an extra 10 pounds, I would be glad to get back. 
Also, thank you Craig Scrivner, Catherine Jeffries, and Ben Norford: Craig for your help setting me up on the Linux machines and walking me through many UNIX commands/error messages. Catherine for your Linux help and answering all my calls to help me troubleshoot GeoClaw when I would accidentally crash it. And Ben for helping me with making my fault model.

Shout out to "the Fellas" at $14^{\text {th }}$ Ave and the "Earthquakers" for all good times, memories, and making my CWU experience worthwhile. Lastly, thank you to Alec Melone for lending me your snowshoes that I used to summit Mt. St. Helens. Here is your acknowledgment that I promised. 


\section{TABLE OF CONTENTS}

Chapter

Page

I INTRODUCTION 1

II

BACKGROUND. 6

Geologic setting ................................................................6

History of occupation and settlement in south-central Chile .............. 13

Geologic paleotsunami field studies in south-central Chile................ 14

Historical earthquakes and tsunamis in south-central Chile .............. 15

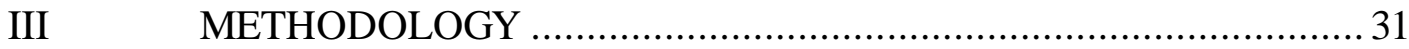

Compiling observational values ................................................. 31

GeoClaw simulations ............................................................. 31

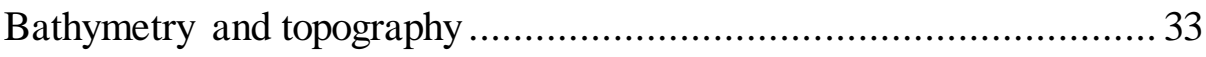

Seafloor deformation and earthquake generation .......................... 34

Simulated tide gauge locations ............................................ 38

AIC statistical analysis .......................................................... 41

Determining a "good-fit" .................................................... 43

Using seafloor deformation to refine "best-fit" model selection.......... 46

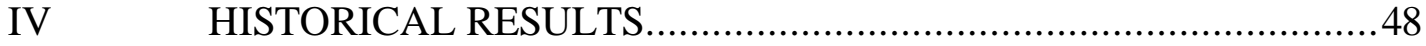

1570 tsunami simulations .....................................................49

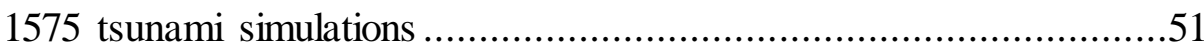

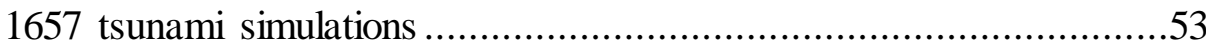

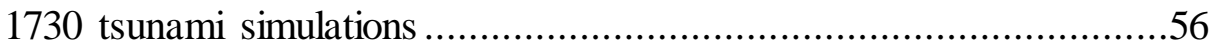

1751 tsunami simulations ..................................................58

1822 tsunami simulations ....................................................61

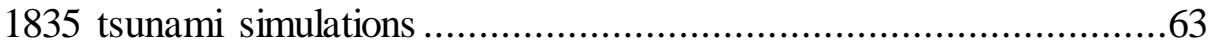

1837 tsunami simulations .........................................................67

1871 tsunami simulations ................................................... 70

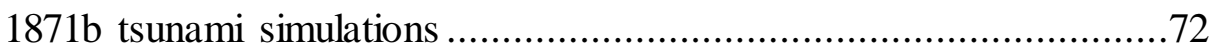

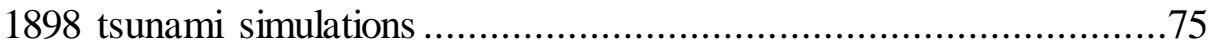

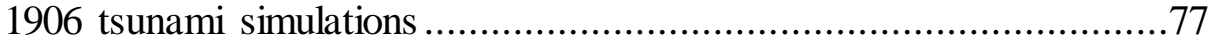

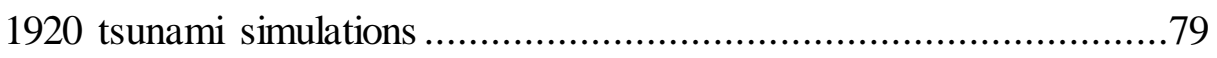

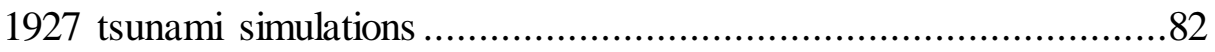

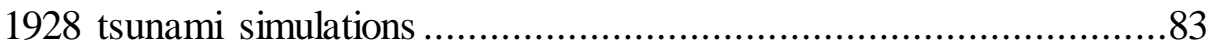

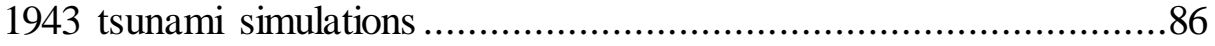




\section{TABLE OF CONTENTS (CONTINUED)}

$\begin{array}{lll}\text { Chapter Page } & \text { Pape }\end{array}$

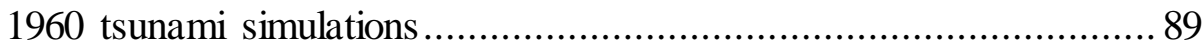

High resolution bathymetry for 1960 analysis ............................ 92

Total water displacement of "best-fitting" 1960 source models .........95

VI DISCUSSION .............................................................. 99

Variable slip models are better than uniform slip models ................. 99

AIC statistical analyses are effective........................................... 100

Historical magnitudes match simulated estimations......................... 105

Why do smaller earthquake solutions fit well for $1960 ? \ldots \ldots \ldots \ldots \ldots \ldots . . . . . .108$

The AIC ranges support the Mocha fracture zone hypothesis............ 113

Analysis of the 1960 event using high-resolution bathymetry ...........115

Model selection at Puerto Saavedra is the most constrained .............. 117

Similarities of the "Barrientos slip" to AIC selected models ..............119

VII $\quad$ SOURCES OF ERROR ..................................................... 121

The historic and geologic maximum wave height database............. 121

Subfault model.................................................................. 122

Numerical modeling........................................................... 123

Validation of models (through AIC) ........................................ 125

VIII SUMMARY AND CONCLUSIONS...................................... 127

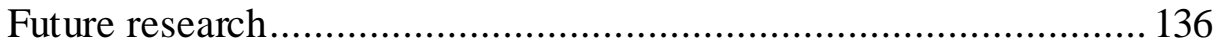

REFERENCES ................................................................. 138

APPENDICES ...................................................................... 151

Appendix A - Fault model........................................................ 151

Appendix B - Stochastic variable slips ....................................... 162

Appendix C - Setrun.py file for GeoClaw simulations .................... 181

Appendix D - Tide gauge observations for AIC analys is ................. 192

Appendix E - Statistical overviews for all events .......................... 205 


\section{LIST OF TABLES}

Table

1 Complete historical tsunami observation database between 1570 and 1960 in south-central Chile......................................................... 8

2 Characteristics of hypothetical earthquake simulations ........................ 38

3 Tide gauge location information for GeoClaw models. .........................39

4 Inundation comparison for three locations using earthquake source models that yielded a $\Delta_{i}$ value less than 4.0 for the 1960 event.....

5 The amount of total water displaced for all 1960 tsunami simulations with a $\Delta_{\mathrm{i}}<4$, the two best-fitting $\mathrm{M}_{\mathrm{w}} 9.5$ tsunami simulations, and the tsunami simulation derived from the Barrientos and Ward (1990) $\mathrm{M}_{\mathrm{w}} 9.0$ earthquake source model.

6 RMSE values (m) of the "best-fitting" earthquake solution for each historical event based on the AIC equations, in addition to the mean RMSE and standard deviation of all solutions for a given historical event

7 Estimated magnitudes in the historical record (from the literature) versus estimated magnitudes from simulations

8 RMSE values of source models ranked as statistically significant from the AIC equations 


\section{LIST OF FIGURES}

$\begin{array}{lll}\text { Figure Page } & \text { Pas }\end{array}$

1 Location of tsunami historical evidence between 1570 and $1960 \ldots \ldots \ldots \ldots . . .7$

2 Chile fault model.............................................................................. 35

3 Area of three locations where $1 / 3$ arc-second bathymetry was used to simulate inundation dynamics ................................................. 45

4 Statistically significant 1570 tsunami simulations............................. 49

$5 \quad$ Selected source models for the 1570 event..................................... 50

6 Statistically significant 1575 tsunami simulations............................... 52

$7 \quad$ Selected source models for the 1575 event..................................... 53

$8 \quad 1657$ statistical overview .............................................................. 54

$9 \quad$ Selected source models for the 1657 event...................................... 55

10 Statistically significant 1730 tsunami simulations............................ 57

11 Selected source model for the 1730 event .......................................58

12 Statistically significant 1751 tsunami simulations...............................5 59

13 Selected source models for the 1751 event.................................... 60

14 Statistically significant 1822 tsunami simulations............................ 62

15 Selected source models for the 1822 event ................................... 63

16 Statistically significant 1835 tsunami simulations............................ 65

17 Selected source models for the 1835 event................................... 66

18 Statistically significant 1837 tsunami simulations..............................6 68

19 Selected source models for the 1837 event.....................................6 69

20 Statistically significant 1871 tsunami simulations............................. 71 


\section{LIST OF FIGURES (CONTINUED)}

Figure

Page

21 Selected source models for the 1871 event................................... 72

22 Statistically significant $1871 b$ tsunami simulations ........................... 73

23 Selected source models for the $1871 \mathrm{~b}$ event ................................. 74

24 Statistically significant 1898 tsunami simulations............................. 76

25 Selected source model for the 1898 event ...................................... 77

26 Statistically significant 1906 tsunami simulations.............................. 78

27 Selected source models for the 1906 event....................................... 79

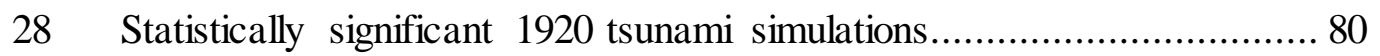

29 Selected source models for the 1920 event...................................... 81

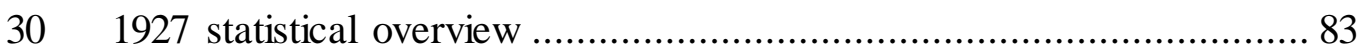

31 Statistically significant 1928 tsunami simulations............................ 84

32 Selected source models for the 1928 event................................... 85

33 Statistically significant 1943 tsunami simulations............................ 87

34 Selected source models for the 1943 event................................... 88

35 Statistically significant 1960 tsunami simulations............................ 90

36 Selected source models for the 1960 event.................................. 91

37 High-resolution tsunami inundation dynamics at three sites ................. 94

38 Slip distributions of models that correctly inundated all three

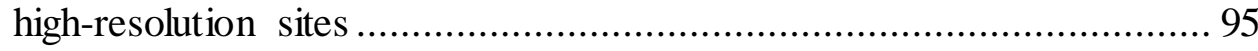

39 Total water displaced on land from top 36 "best-fitting" tsunami simulations to the 1960 event ..................................................... 98

$40 \quad$ Modeled residuals of the 1960 observations.................................... 112 


\section{LIST OF FIGURES (CONTINUED)}

Figure

Page

41 "Barrientos slip" earthquake source model derived from Barrientos and Ward (1990) 


\section{CHAPTER I}

\section{INTRODUCTION}

Reliable forecasts are a necessary component of accurate advisory and warning messages in the case of an impending tsunami. Models can predict flooding in highly vulnerable areas along the coast, but models rely on accurate initial conditions, including the rupture dynamics of tsunamigenic earthquakes. Currently, little is known about the rupture characteristics of most pre-20 th century events; the methods used today to study detailed rupture dynamics, such as GPS and seismologic data, are all inventions of the last century, and as such only work for modern events. To improve tsunami forecasts with a multi-century perspective of rupture dynamics, it is critical to understand how a subduction zone behaved during pre-20 $0^{\text {th }}$ century events. In some locations, written accounts provide enough evidence to estimate some earthquake details, such as magnitude $\left(\mathrm{M}_{\mathrm{w}}\right)$ and the area of rupture (Lagos 2000; Lomnitz, 2004; Udias et al., 2012). With the addition of paleotsunami geological studies, these estimates can be refined to include better precision of magnitude and location, and potentially also estimates of location of high slip (Hirata et al., 2003; Nanayama et al., 2003; Satake et al., 2003; Satake and Atwater, 2007; MacInnes et al., 2010; Atwater et al., 2016).

In this research I plan to use observed historic and geologic tsunami evidence as a benchmark to define the inundating properties of known tsunamis, which I will link to the rupture properties of the earthquake that produced these tsunamis (MacInnes et al., 2010). The initial water disturbance by a subduction zone earthquake that generates a tsunami directly reflects the seafloor deformation pattern produced by the earthquake's rupture pattern. Many of these details of original rupture characteristics are preserved in the 
tsunami as it propagates (Okal, 2009). For example, Geist (2002) suggests that tsunami flooding in the near-field is sensitive to the source parameters of an earthquake independent to seismic moment, such as the distribution of slip. Because a tsunami deposit on land is considered a good proxy for the horizontal distance of tsunami penetration (inundation) and the elevation above mean sea level (runup) (MacInnes et al., 2013), the overall deposit distribution in the near-field may preserve details of original rupture characteristics, such as details the earthquake's slip distribution (Satake et al., 2003; Satake et al., 2008; MacInnes et al., 2010; MacInnes et al., 2013).

The goal of my research was to create and evaluate a new methodology to statistically assess possible rupture parameters of known pre-instrumental earthquakes. First, I built a database of forward-modeled numerical tsunami simulations from hundreds of earthquake sources that defined realistic possible rupture patterns on a subduction zone. The earthquake sources had stochastic (i.e. randomly determined) variable finite-slip distributions. The detailed historical record and paleotsunami deposit database that I compiled provides a means identify a suite of earthquake source models and their associated simulated tsunamis that best replicate the known maximum wave heights from a specific historical event. Finally, I evaluated the suite of best earthquake models to estimate rupture characteristics for known earthquakes.

The method of statistically selecting earthquake models that I used for this study was Akaike's information criterion (AIC) statistical modeling (Burnham and Anderson, 2002). AIC provided a simple, effective, and objective way to analyze a large data set for the selection of an estimated "best approximating model" (Burnham and Anderson, 2002). AIC determined its model selection based on information theory and Bayesian 
methods (Burnham and Anderson, 2002). This newer paradigm in the statistical sciences is an extension to R.A. Fisher's maximum likelihood principle (Kullback, 1959; Akaike, 1974). The process of model selection has new philosophical and computational advantages, which is different from previous methods based on null hypothesis testing (Akaike, 1974; Anderson et al., 2000; Breihman, 2001; Burnham and Anderson, 2002). Chile was an excellent candidate for this new methodology because there is an extensive earthquake written record dating to the 1500 s with previously estimated slip distributions for specific earthquake events (e.g. 1960; Barrientos and Ward, 1990; Moreno et al., 2009; NGDC/WGS, 2018 ). Recovered writings from Spanish conquistadors' supports evidence of Chile having one of the world's most active interplate margins (Cisternas et al., 2005). In south-central Chile $\left(46^{\circ} \mathrm{S}\right.$ to $\left.30^{\circ} \mathrm{S}\right)$, at least 17 destructive tsunamigenic events occurred between AD 1570 and 1960; the 1960 earthquake $\left(\mathrm{M}_{\mathrm{w}} 9.5\right)$ was instrumentally recorded as the largest earthquake in modern history (NGDC/WDS, 2018). Additionally, south-central Chile has nine localities with good preservation of the tsunami record studied in detail to date. South-central Chile's warm and temperate climate, in addition to its coastal geomorphology (many marshes and beach swales) allow for this preservation of geologic tsunami evidence. These 17 events all have rough estimates of $\mathrm{M}_{\mathrm{w}}$ and general rupture position, but few solutions of rupture parameters have been defined with any confidence (Lagos, 2000; Lomnitz 2004; Udias et al., 2012; NGDC/WDS, 2018).

Although this study's goal is to interpret pre-20 $20^{\text {th }}$ century earthquakes, I include the 1960 earthquake as means to validate the statistical results of this new methodology. The 1960 event has two previously published slip distributions associated with it that 
hypothesize a long rupture extent along strike (Barrientos and Ward, 1990; Moreno et al., 2009). The 1960 tsunami also has $\sim 29$ nearshore locations over $\sim 1,120 \mathrm{~km}$ with historic or geologic tsunami evidence (Saint-Amand, 1963; Sievers et al., 1963; Weischet, 1963; Iida et al., 1967; Iida, 1984; Atwater et al., 1999; Lagos, 2000; Fritz et al., 2011; Atwater et al., 2013; Ely et al., 2014; Garrett et al, 2015; Carvajal et al., 2017; Cisternas et al. 2017; Dura et al., 2017; Hong et al. 2017; Kempf et al., 2017; L. Ely Pers. Comm., 2019; Matos-Llavona et al., 2019).

In addition to having a long record of known tsunamis, Chile's subduction zone also poses an interesting, yet simple test case to study whether this methodology can show subduction-zone dynamics over the centuries time scale. The south-central Chile subduction zone is proposed to be divided into two segments that rupture independently, separated by the Mocha fracture zone (MFZ; Contreras-Reyes and Carrizo, 2011). Because coastal marine terraces at this latitude reveal $\sim 200 \mathrm{~m}$ of relief and demonstrate zones of rapid coastal uplift, the MFZ is hypothesized to continue as a subducted fracture zone under the Isla Mocha region at $\sim 38.3^{\circ}$ S (Contreras-Reyes et al., 2008; Melnick et al., 2009; Jara-Munoz et al., 2015). Whether or not fracture zones such as the MFZ control rupture propagation is an open question. The statistical analysis of hundreds of modeled earthquake scenarios should be able to test whether the MFZ may have inhibited rupture propagation in the past 500 years. Specific suites of earthquakes with a "good-fit" arising on one side of the MFZ, but not crossing the MFZ boundary would support this claim.

Earthquake source models that generate tsunami simulations that best match the paleotsunami and historical observations of past south-central Chile tsunamigenic events 
have the potential to provide spatial and temporal information about the behavior of the Chilean subduction zone. The outcome of this research shows how current paleotsunami deposits can be used in the understanding of earthquake rupture characteristics from past events along the coast. This research may lead to applications for identifying coastal vulnerability, potential future tsunami forecasting, and hazard preparedness in coastal communities. 


\section{CHAPTER II}

\section{BACKGROUND}

\section{Geologic setting}

Recovered historical writing and geologic paleotsunami studies show that Chile is one of the most seismically active locations in the world. Chile's entire 4,270-km long coastline sits alongside the Chilean subduction zone. Here, the Nazca Plate is subducting at $\sim 15^{\circ}$ underneath the South American at $\sim 6.6 \mathrm{~cm} / \mathrm{yr}$ (Angermann et al., 1999). Because of the fast rate of subduction in south-central Chile, there have been as many as 17 historical tsunamigenic earthquakes from 1570 AD to 1960 AD in south-central Chile (Figure 1; Table 1), between $46.2^{\circ} \mathrm{S}$ (the Chile Triple Junction) and $30.57^{\circ} \mathrm{S}$ (the Limari Province; FitzRoy, 1839; Milne 1900a; Milne, 1911; Davidson, 1936; Berninghausen, 1962; Sievers et al., 1963; Weischet, 1963; Iida et al., 1967; Lomnitz, 1970; Soloviev and Go, 1975; Instituto Hidrografico de la Armada, 1982; Iida, 1984; Lockridge, 1985; Van Dorn, 1987; Lander and Lockridge, 1989; Monge 1993; Atwater et al., 1999; Lagos, 2000; Lomnitz, 2004; Cisternas et al., 2005; Fritz et al., 2011; Udias et al., 2012; Valenuela, 2012; Wang et al., 2012; Atwater et al., 2013; Ely et al., 2014; Garrett et 1., 2015; Urbina Carrasco et al., 2016; Carvajal et al., 2017; Cisternas et al., 2017; Dura et al., 2017; Hong et al., 2017; Kempf et al., 2017). Just within the last 60 years, two major earthquakes occurred in south-central Chile: the $1960 \mathrm{M}_{\mathrm{w}} 9.5$ earthquake off the coast of Valdivia (Weischet, 1963), and the $2010 \mathrm{M}_{\mathrm{w}} 8.8$ earthquake off the coast of Maule (Fritz et al., 2011). 


\section{Tsunami historical evidence}
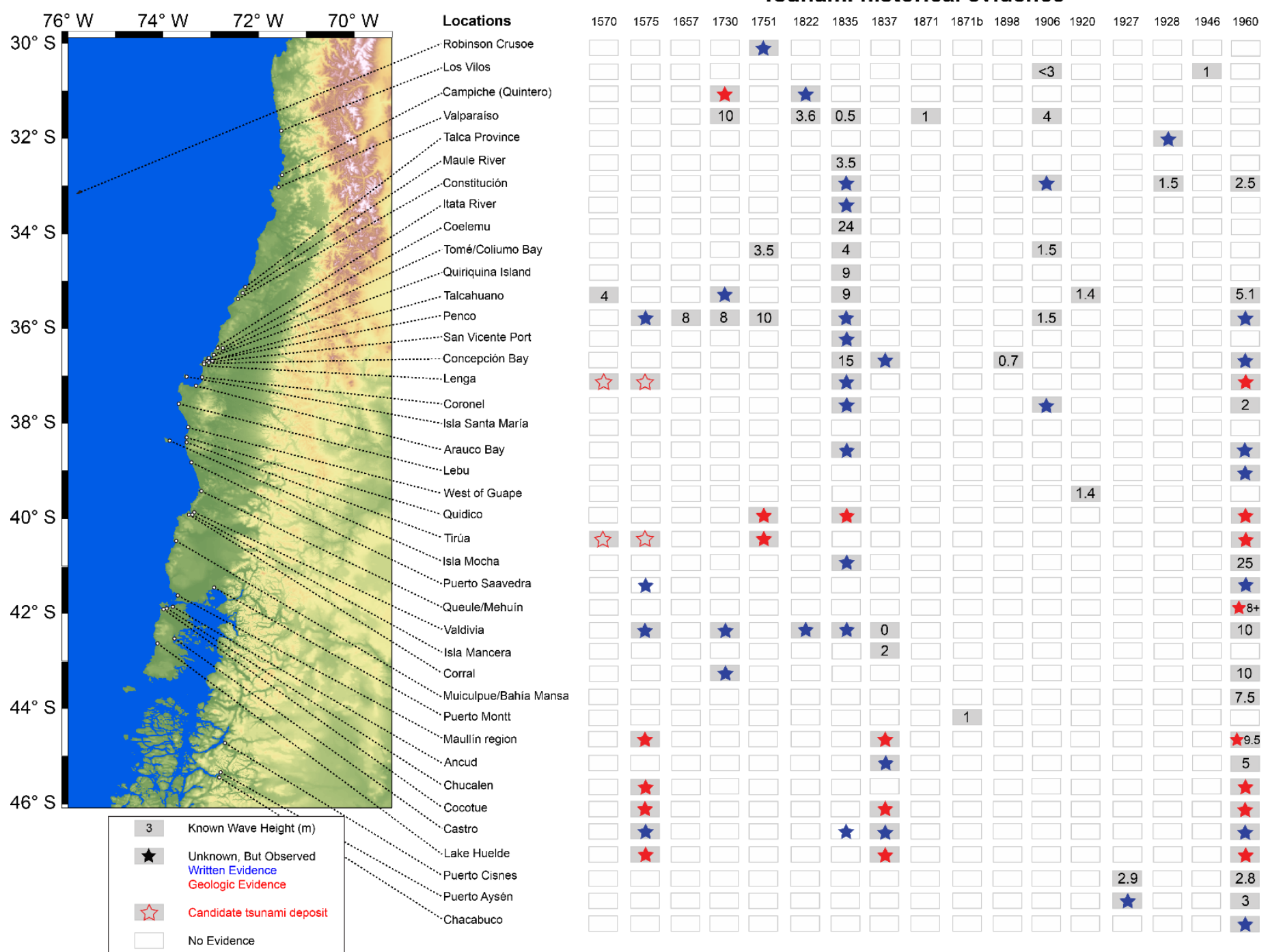

Figure 1: Location of tsunami historical evidence for 17 tsunamigenic earthquake events between 1570 and 1960 . Numbers indicate maximum wave heights (m) recorded ("0" refers to documentation of no tsunami recording). Stars indicate unspecified maximum wave heights within the geologic record ( $\mathrm{red}=$ geologic evidence, blue $=$ written evidence, open red $=$ candidate tsunami deposit) Refer to Table 1 for original sources of all data. 
Table 1: Complete historical tsunami observation database between 1570 and 1960 in south-central Chile. "O" indicates unspecified maximum wave height within the historical record. " $\mathrm{X}$ " indicates documentation of no tsunami recording.

\begin{tabular}{|c|c|c|c|c|c|c|c|c|}
\hline Year & Date & $\begin{array}{l}\text { Estimated } \\
\text { magnitude }\end{array}$ & $\begin{array}{l}\text { Latitude } \\
\quad\left({ }^{\circ} \mathbf{S}\right)\end{array}$ & $\begin{array}{l}\text { Longitude } \\
\left({ }^{\circ} \mathbf{W}\right)\end{array}$ & Location & $\begin{array}{l}\text { Maximum } \\
\text { wave } \\
\text { height }(m)\end{array}$ & $\begin{array}{c}\text { Type of } \\
\text { observation }\end{array}$ & $\begin{array}{l}\text { Maximum } \\
\text { wave height } \\
\text { citation }\end{array}$ \\
\hline \multirow{3}{*}{1570} & \multirow{3}{*}{$\begin{array}{l}8- \\
\text { Feb }\end{array}$} & \multirow{3}{*}{ M $8.0-8.5$} & 36.73617 & 72.99081 & Penco & 4 & Written & $\begin{array}{l}\text { Soloviev and } \\
\text { Go, } 1975\end{array}$ \\
\hline & & & 36.77093 & 73.16522 & Lenga & $\mathrm{O}^{* *}$ & Geologic & $\begin{array}{l}\text { L. Ely Pers } \\
\text { Comm., } 2018\end{array}$ \\
\hline & & & 38.34447 & 73.48758 & Tirúa & $\mathrm{O}^{* *}$ & Geologic & $\begin{array}{l}\text { L. Ely Pers. } \\
\text { Comm., } 2018\end{array}$ \\
\hline \multirow{11}{*}{1575} & \multirow{11}{*}{$\begin{array}{l}\text { 17- } \\
\text { Mar }\end{array}$} & \multirow{11}{*}{$\begin{array}{c}\text { Similar to } \\
1960 \mathrm{M}_{\mathrm{w}} \\
9.5\end{array}$} & 36.73617 & 72.99081 & Penco & $\mathrm{O}$ & Written & $\begin{array}{l}\text { Soloviev and } \\
\text { Go, } 1975\end{array}$ \\
\hline & & & 36.77093 & 73.16522 & Lenga & $\mathrm{O}^{* *}$ & Geologic & $\begin{array}{l}\text { L. Ely Pers } \\
\text { Comm., } 2018\end{array}$ \\
\hline & & & 38.32930 & 73.48824 & Tirúa & $\mathrm{O}$ & Geologic & Ely et al., 2014 \\
\hline & & & 38.34447 & 73.48758 & Tirúa & $\mathrm{O}^{* *}$ & Geologic & $\begin{array}{l}\text { L. Ely Pers } \\
\text { Comm., } 2018\end{array}$ \\
\hline & & & $38.78323 *$ & 73.40182 & $\begin{array}{l}\text { Puerto } \\
\text { Saavedra }\end{array}$ & $\mathrm{O}$ & Written & $\begin{array}{l}\text { Cisternas et al., } \\
2005\end{array}$ \\
\hline & & & 39.81743 & 73.26205 & Valdivia & $\mathrm{O}$ & Written & Lomnitz, 2004 \\
\hline & & & 41.63198 & 73.57816 & Maullín & $\mathrm{O}$ & Geologic & $\begin{array}{l}\text { Cisternas et al., } \\
2017\end{array}$ \\
\hline & & & 41.84600 & 74.00039 & Chucalen & $\mathrm{O}$ & Geologic & $\begin{array}{l}\text { Garrett et al., } \\
2015\end{array}$ \\
\hline & & & 41.92361 & 74.00299 & Cocotue & $\mathrm{O}$ & Geologic & $\begin{array}{l}\text { Cisternas et al., } \\
2017\end{array}$ \\
\hline & & & $42.48118^{*}$ & $73.75943^{*}$ & Castro & $\mathrm{O}$ & Written & Lomnitz, 2004 \\
\hline & & & 42.59949 & 74.11395 & Lake Huelde & $\mathrm{O}$ & Geologic & $\begin{array}{l}\text { Kempf et al., } \\
2017\end{array}$ \\
\hline 1657 & $\begin{array}{l}15- \\
\text { Mar }\end{array}$ & M 8.0 & 36.73617 & 72.99081 & Penco & 8 & Written & Lomnitz, 2004 \\
\hline \multirow{4}{*}{$\begin{array}{c}1730 \\
\text { (cont. } \\
\text { onto } \\
\text { next } \\
\text { page) }\end{array}$} & \multirow{4}{*}{ 8-Jul } & \multirow{4}{*}{ M $9.1-9.3$} & 32.75595 & 71.46517 & $\begin{array}{l}\text { Campiche } \\
\text { (Quintero) }\end{array}$ & $\mathrm{O}$ & Geologic & $\begin{array}{l}\text { M. Carvajal } \\
\text { Pers. Comm., } \\
2019 \\
\end{array}$ \\
\hline & & & 33.03948 & 71.62942 & Valparaíso & 10 & Written & $\begin{array}{l}\text { Carvajal et al., } \\
2017\end{array}$ \\
\hline & & & $36.72474 *$ & $73.10445^{*}$ & Talcahuano & $\mathrm{O}$ & Written & $\begin{array}{l}\text { Instituto } \\
\text { Hidrografico } \\
\text { de la Armada, } \\
1982\end{array}$ \\
\hline & & & 36.73617 & 72.99081 & Penco & 8 & Written & $\begin{array}{l}\text { Carvajal et al., } \\
2017\end{array}$ \\
\hline
\end{tabular}




\begin{tabular}{|c|c|c|c|c|c|c|c|c|}
\hline Year & Date & $\begin{array}{l}\text { Estimated } \\
\text { magnitude }\end{array}$ & $\begin{array}{l}\text { Latitude } \\
\quad\left({ }^{\circ} \mathbf{S}\right)\end{array}$ & $\begin{array}{c}\text { Longitude } \\
\left({ }^{\circ} \mathbf{W}\right)\end{array}$ & Location & $\begin{array}{l}\text { Maximum } \\
\text { wave } \\
\text { height }(\mathrm{m})\end{array}$ & $\begin{array}{c}\text { Type of } \\
\text { observation }\end{array}$ & $\begin{array}{c}\text { Maximum } \\
\text { wave height } \\
\text { citation }\end{array}$ \\
\hline & & & 39.81743 & 73.26206 & Valdivia & $\mathrm{O}$ & Written & $\begin{array}{l}\text { Soloviev and } \\
\text { Go, } 1975\end{array}$ \\
\hline & & & 39.88387 & 73.42598 & Corral & $\mathrm{O}$ & Written & $\begin{array}{l}\text { Instituto } \\
\text { Hidrografico de } \\
\text { la Armada, } \\
1982\end{array}$ \\
\hline \multirow{5}{*}{1751} & \multirow{5}{*}{$\begin{array}{l}25- \\
\text { Mar }\end{array}$} & \multirow{5}{*}{$\begin{array}{l}\text { Similar to } \\
2010 \mathrm{M}_{\mathrm{w}} \\
8.8\end{array}$} & $33.64150 *$ & 78.84610 & $\begin{array}{l}\text { Robinson } \\
\text { Crusoe; Juan } \\
\text { Fernandez } \\
\text { Islands }\end{array}$ & $\mathrm{O}$ & Written & $\begin{array}{l}\text { Lyell, 1875; } \\
\text { Udias, } 2012\end{array}$ \\
\hline & & & 36.54621 & 72.93624 & $\begin{array}{l}\text { Coliumo Bay } \\
\text { (Los Morros) }\end{array}$ & 3.5 & Written & Lagos, 2000 \\
\hline & & & 36.73617 & 72.99081 & Penco & 10 & Written & $\begin{array}{l}\text { Udias et al., } \\
2012\end{array}$ \\
\hline & & & 38.25070 & 73.49290 & Quidico & $\mathrm{O}$ & Geologic & $\begin{array}{l}\text { Hong et al., } \\
2017\end{array}$ \\
\hline & & & 38.32930 & 73.48824 & Tirúa & $\mathrm{O}$ & Geologic & Ely et al., 2014 \\
\hline \multirow{3}{*}{1822} & \multirow{3}{*}{$\begin{array}{l}19- \\
\text { Nov }\end{array}$} & \multirow{3}{*}{ M $8.0-8.5$} & 32.75595 & 71.46517 & Quintero & $\mathrm{O}$ & Written & $\begin{array}{l}\text { Soloviev and } \\
\text { Go, } 1975\end{array}$ \\
\hline & & & 33.04271 & 71.69600 & Valparaíso & 3.6 & Written & $\begin{array}{l}\text { Soloviev and } \\
\text { Go, 1975; } \\
\text { Lomnitz, } 2004\end{array}$ \\
\hline & & & 39.81743 & 73.26205 & Valdivia & $\mathrm{O}$ & Written & $\begin{array}{l}\text { Soloviev and } \\
\text { Go, } 1975\end{array}$ \\
\hline \multirow{9}{*}{$\begin{array}{l}1835 \\
\text { (cont. } \\
\text { onto } \\
\text { next } \\
\text { page) }\end{array}$} & \multirow{9}{*}{$\begin{array}{l}20- \\
\text { Feb }\end{array}$} & \multirow{9}{*}{ M $8.2-8.5$} & 33.04271 & 71.69600 & Valparaíso & 0.5 & Written & Lomnitz, 2004 \\
\hline & & & $35.31632 *$ & 72.41130 & Maule River & 3.5 & Written & $\begin{array}{l}\text { Soloviev and } \\
\text { Go, } 1975\end{array}$ \\
\hline & & & $35.32786^{*}$ & 72.42865 & Constitución & $\mathrm{O}$ & Written & $\begin{array}{l}\text { Soloviev and } \\
\text { Go, } 1975\end{array}$ \\
\hline & & & $36.47846^{*}$ & 72.69542 & Coelemu & 24 & Written & $\begin{array}{l}\text { Soloviev and } \\
\text { Go, } 1975\end{array}$ \\
\hline & & & 36.48430 & 72.90664 & Itata River & $\mathrm{O}$ & Written & $\begin{array}{l}\text { Soloviev and } \\
\text { Go, } 1975\end{array}$ \\
\hline & & & 36.54621 & $72.93624^{*}$ & $\begin{array}{l}\text { Coliumo Bay } \\
\text { (Los Morros) }\end{array}$ & 4 & Written & FitRoy, 1839 \\
\hline & & & 36.61774 & 72.96333 & Tomé & 4 & Written & $\begin{array}{l}\text { Soloviev and } \\
\text { Go, } 1975\end{array}$ \\
\hline & & & 36.63735 & 73.05999 & $\begin{array}{l}\text { Quiriquina } \\
\text { Island }\end{array}$ & 9 & Written & $\begin{array}{l}\text { Soloviev and } \\
\text { Go, } 1975\end{array}$ \\
\hline & & & $36.72474 *$ & $73.10445^{*}$ & Talcahuano & 9 & Written & $\begin{array}{l}\text { Soloviev and } \\
\text { Go, } 1975\end{array}$ \\
\hline
\end{tabular}




\begin{tabular}{|c|c|c|c|c|c|c|c|c|}
\hline Year & Date & $\begin{array}{l}\text { Estimated } \\
\text { magnitude }\end{array}$ & $\begin{array}{l}\text { Latitude } \\
\quad\left({ }^{\circ} \mathbf{S}\right)\end{array}$ & $\begin{array}{c}\text { Longitude } \\
\left({ }^{\circ} \mathbf{W}\right)\end{array}$ & Location & $\begin{array}{c}\text { Maximum } \\
\text { wave } \\
\text { height }(\mathrm{m})\end{array}$ & $\begin{array}{c}\text { Type of } \\
\text { observation }\end{array}$ & $\begin{array}{c}\text { Maximum } \\
\text { wave height } \\
\text { citation }\end{array}$ \\
\hline & & & 36.72917 & 73.13777 & $\begin{array}{l}\text { San Vicente } \\
\text { Port } \\
\text { (Concepción) }\end{array}$ & $\mathrm{O}$ & Written & $\begin{array}{l}\text { Soloviev and } \\
\text { Go, } 1975\end{array}$ \\
\hline & & & 36.73471 & 73.05561 & $\begin{array}{c}\text { Concepción } \\
\text { Bay }\end{array}$ & 15 & Written & Lomnitz, 2004 \\
\hline & & & 36.73617 & 72.99081 & Penco & $\mathrm{O}$ & Written & $\begin{array}{l}\text { Soloviev and } \\
\text { Go, } 1975\end{array}$ \\
\hline & & & 36.77093 & 73.16522 & Lenga & $\mathrm{O}$ & Written & FitzRoy, 1839 \\
\hline & & & 37.04550 & 73.51033 & $\begin{array}{l}\text { Isla Santa } \\
\text { María }\end{array}$ & $\mathrm{O}$ & Written & $\begin{array}{l}\text { FitzRoy, } 1839 \text {; } \\
\text { Wesson et al., } \\
2015\end{array}$ \\
\hline & & & 37.23680 & 73.30788 & Arauco & $\mathrm{O}$ & Written & $\begin{array}{l}\text { Soloviev and } \\
\text { Go, } 1975\end{array}$ \\
\hline & & & 38.25070 & 73.49290 & Quidico & $\mathrm{O}$ & Geologic & $\begin{array}{l}\text { Hong et al., } \\
2017\end{array}$ \\
\hline & & & 38.37465 & 73.86740 & Isla Mocha & $\mathrm{O}$ & Written & FitRoy, 1839 \\
\hline & & & 39.81743 & $73.262045^{*}$ & Valdivia & $\mathrm{O}$ & Written & FitRoy, 1839 \\
\hline & & & $42.481176 *$ & $73.75943^{*}$ & Castro & $\mathrm{O}$ & Written & $\begin{array}{l}\text { Soloviev and } \\
\text { Go, } 1975\end{array}$ \\
\hline \multirow{9}{*}{1837} & \multirow{9}{*}{$\begin{array}{l}7- \\
\text { Nov }\end{array}$} & \multirow{9}{*}{ M $8.0-8.5$} & 36.73471 & 73.05561 & $\begin{array}{c}\text { Concepción } \\
\text { Bay }\end{array}$ & $\mathrm{O}$ & Written & $\begin{array}{l}\text { Cisternas et al., } \\
2005\end{array}$ \\
\hline & & & 39.81743 & 73.26205 & Valdivia & $X$ & Written & Iida, 1984 \\
\hline & & & $39.89045^{*}$ & 73.39495 & Isla Mancera & 2 & Written & $\begin{array}{l}\text { Lockridge, } \\
1985\end{array}$ \\
\hline & & & 41.59498 & 73.59854 & $\begin{array}{l}\text { Western } \\
\text { Maullín }\end{array}$ & $\mathrm{O}$ & Geologic & $\begin{array}{l}\text { Cisternas et al., } \\
2005\end{array}$ \\
\hline & & & 41.63198 & 73.57816 & Maullín & $\mathrm{O}$ & Geologic & $\begin{array}{l}\text { Cisternas et al., } \\
2005\end{array}$ \\
\hline & & & 41.86663 & 73.82977 & Ancud & $\mathrm{O}$ & Written & $\begin{array}{l}\text { Soloviev and } \\
\text { Go, } 1975\end{array}$ \\
\hline & & & 41.92361 & 74.00299 & Cocotue & $\mathrm{O}$ & Geologic & $\begin{array}{l}\text { Cisternas et al., } \\
2017\end{array}$ \\
\hline & & & $42.48118^{*}$ & $73.75943^{*}$ & Castro & $\mathrm{O}$ & Written & $\begin{array}{l}\text { Berninghausen, } \\
1962\end{array}$ \\
\hline & & & 42.59949 & 74.11395 & Lake Huelde & $\mathrm{O}$ & Geologic & $\begin{array}{l}\text { Kempf et al., } \\
2017\end{array}$ \\
\hline 1871 & $\begin{array}{l}25- \\
\text { Mar }\end{array}$ & M 7.5 & 33.04271 & 71.69600 & Valparaíso & 1 & Written & $\begin{array}{l}\text { Lockridge, } \\
1985\end{array}$ \\
\hline $1871 b$ & $\begin{array}{l}28- \\
\text { Dec }\end{array}$ & $\mathrm{n} / \mathrm{a}$ & $41.486024 *$ & 72.96388 & Puerto Montt & 1 & Written & $\begin{array}{l}\text { Lockridge, } \\
1985\end{array}$ \\
\hline 1898 & $\begin{array}{l}23- \\
\text { Jul }\end{array}$ & M 6.5 & 36.73471 & 73.05561 & $\begin{array}{c}\text { Concepción } \\
\text { Bay }\end{array}$ & 0.7 & Written & $\begin{array}{l}\text { Milne, 1900a; } \\
\text { Lockridge, } \\
1985\end{array}$ \\
\hline
\end{tabular}




\begin{tabular}{|c|c|c|c|c|c|c|c|c|}
\hline Year & Date & $\begin{array}{l}\text { Estimated } \\
\text { magnitude }\end{array}$ & $\begin{array}{l}\text { Latitude } \\
\quad\left({ }^{\circ} \mathbf{S}\right)\end{array}$ & $\begin{array}{l}\text { Longitude } \\
\qquad\left({ }^{\circ} \mathbf{W}\right)\end{array}$ & Location & $\begin{array}{l}\text { Maximum } \\
\text { wave } \\
\text { height }(\mathbf{m})\end{array}$ & $\begin{array}{c}\text { Type of } \\
\text { observation }\end{array}$ & $\begin{array}{l}\text { Maximum } \\
\text { wave height } \\
\text { citation }\end{array}$ \\
\hline \multirow{6}{*}{1906} & \multirow{6}{*}{$\begin{array}{l}16- \\
\text { Aug }\end{array}$} & \multirow{6}{*}{ M $8.2-8.6$} & 31.90929 & $71.51158 *$ & Los Vilos & $<3$ & Written & Lagos, 2000 \\
\hline & & & 33.04271 & 71.69600 & Valparaíso & 4 & Written & Lagos, 2000 \\
\hline & & & $35.32786^{*}$ & 72.42865 & $\begin{array}{c}\text { Small } \\
\text { settlements } \\
\text { near } \\
\text { Constitución }\end{array}$ & $\mathrm{O}$ & Written & $\begin{array}{l}\text { Soloviev and } \\
\text { Go, } 1975\end{array}$ \\
\hline & & & 36.61774 & 72.96333 & Tomé & 1.5 & Written & $\begin{array}{l}\text { Soloviev and } \\
\text { Go, } 1975\end{array}$ \\
\hline & & & 36.73664 & 72.99600 & Penco & 1.5 & Written & $\begin{array}{l}\text { Soloviev and } \\
\text { Go, } 1975\end{array}$ \\
\hline & & & 37.03602 & $73.14661 *$ & Coronel & $\mathrm{O}$ & Written & $\begin{array}{l}\text { Soloviev and } \\
\text { Go, } 1975\end{array}$ \\
\hline \multirow{2}{*}{1920} & \multirow{2}{*}{$\begin{array}{l}20- \\
\text { Aug }\end{array}$} & \multirow{2}{*}{ M 7.0} & $36.72474 *$ & $73.10445^{*}$ & Talcahuano & 1.4 & Written & $\begin{array}{l}\text { Berninghausen, } \\
\text { 1962; Lockride, } \\
1985\end{array}$ \\
\hline & & & 37.99779 & 73.47869 & $\begin{array}{l}\text { West of } \\
\text { Guape }\end{array}$ & 1.4 & Written & Lagos, 2000 \\
\hline \multirow{2}{*}{1927} & \multirow{2}{*}{$\begin{array}{c}21- \\
\text { Nov }\end{array}$} & \multirow{2}{*}{ M 7.1} & 44.73059 & 72.68421 & $\begin{array}{c}\text { West of } \\
\text { Puerto Cisnes }\end{array}$ & 2.9 & Written & $\begin{array}{l}\text { lida et al., } \\
\text { 1967; Soloviev } \\
\text { and Go, } 1975\end{array}$ \\
\hline & & & 45.40257 & 72.82976 & Puerto Aysen & $\mathrm{O}$ & Written & $\begin{array}{l}\text { Lockridge, } \\
1985\end{array}$ \\
\hline \multirow[b]{2}{*}{1928} & \multirow[b]{2}{*}{$\begin{array}{c}1- \\
\text { Dec }\end{array}$} & \multirow{2}{*}{$\begin{array}{c}\text { M } 7.6 \text { to } \\
8.4\end{array}$} & $35.03805^{*}$ & 72.16394 & $\begin{array}{c}\text { Talca } \\
\text { Province }\end{array}$ & $\mathrm{O}$ & Written & $\begin{array}{l}\text { Soloviev and } \\
\text { Go, } 1975\end{array}$ \\
\hline & & & $35.32786^{*}$ & 72.42865 & Constitución & 1.5 & Written & $\begin{array}{l}\text { Lomnitz, 2004; } \\
\text { Soloviev and } \\
\text { Go, } 1975\end{array}$ \\
\hline 1943 & $\begin{array}{c}\text { 6- } \\
\text { Apr }\end{array}$ & M 8.3 & $31.90929 *$ & 71.51158 & Los Vilos & 1 & Written & $\begin{array}{l}\text { Lagos, 2000; } \\
\text { Lomnitz, } 2004\end{array}$ \\
\hline \multirow{7}{*}{$\begin{array}{l}1960 \\
\text { (cont. } \\
\text { onto } \\
\text { next } \\
\text { page) }\end{array}$} & & \multirow{7}{*}{$\mathrm{M}_{\mathrm{w}} 9.5$} & $35.32786^{*}$ & 72.42866 & Constitución & 2.5 & Written & Iida et al., 1967 \\
\hline & & & $36.72474^{*}$ & $73.10445^{*}$ & Talcahuano & 5.1 & Written & $\begin{array}{l}\text { Fritz et al., } \\
2011\end{array}$ \\
\hline & & & 36.73471 & 73.05561 & $\begin{array}{c}\text { Concepción } \\
\text { Bay }\end{array}$ & $\mathrm{O}$ & Written & Iida, 1967 \\
\hline & & & 36.73617 & 72.99081 & Penco & $\mathrm{O}$ & Written & $\begin{array}{l}\text { Carvajal et al., } \\
2017\end{array}$ \\
\hline & & & 36.77093 & 73.16522 & Lenga & $\mathrm{O}$ & Geologic & $\begin{array}{l}\text { L. Ely Pers. } \\
\text { Comm, } 2019\end{array}$ \\
\hline & & & 37.03602 & $73.14661^{*}$ & Coronel & 2 & Written & Iida et al., 1967 \\
\hline & & & 37.23680 & 73.30788 & Arauco & $\mathrm{O}$ & Written & Iida et al., 1967 \\
\hline
\end{tabular}




\begin{tabular}{|c|c|c|c|c|c|c|c|c|}
\hline Year & Date & $\begin{array}{l}\text { Estimated } \\
\text { magnitude }\end{array}$ & $\begin{array}{l}\text { Latitude } \\
\quad\left({ }^{\circ} \mathbf{S}\right)\end{array}$ & $\begin{array}{l}\text { Longitude } \\
\left({ }^{\circ} \mathbf{W}\right)\end{array}$ & Location & $\begin{array}{l}\text { Maximum } \\
\text { wave } \\
\text { height }(m)\end{array}$ & $\begin{array}{c}\text { Type of } \\
\text { observation }\end{array}$ & $\begin{array}{l}\text { Maximum } \\
\text { wave height } \\
\text { citation }\end{array}$ \\
\hline & & & 37.59129 & 73.64870 & Lebu & $\mathrm{O}$ & Written & Lagos, 2000 \\
\hline & & & 38.25070 & 73.49290 & Quidico & $\mathrm{O}$ & Geologic & $\begin{array}{l}\text { Dura et al., } \\
\text { 2017; Hong et } \\
\text { al. } 2017\end{array}$ \\
\hline & & & 38.32930 & 73.48824 & Tirúa & $\mathrm{O}$ & Geologic & Ely et al., 2014 \\
\hline & & & 38.37465 & 73.86740 & Isla Mocha & 25 & Written & Iida, 1984 \\
\hline & & & 38.78323 & 73.40182 & $\begin{array}{l}\text { Puerto } \\
\text { Saavedra }\end{array}$ & 11.5 & Written & Weischet, 1963 \\
\hline & & & 39.39792 & 73.21172 & Queule & $\mathrm{O}$ & Geologic & $\begin{array}{l}\text { Matos-Llavona } \\
\text { et al., } 2019\end{array}$ \\
\hline & & & 39.42997 & 73.21527 & Mehuín & 8 to 15 & Written & $\begin{array}{l}\text { Weischet, } \\
\text { 1963; Iida, } \\
1984 \\
\end{array}$ \\
\hline & & & 39.81743 & 73.26204 & Valdivia & 10 & Written & Iida, 1984 \\
\hline & & & 39.88387 & 73.42598 & Corral & 10 & Written & Iida, 1984 \\
\hline & & & 40.58421 & 73.73598 & $\begin{array}{l}\text { Muiculpue/ } \\
\text { Bahía Mansa }\end{array}$ & 7.5 & Written & Weischet, 1963 \\
\hline & & & 73.6782 & 41.57341 & $\begin{array}{l}\text { Maullín } \\
\text { region }\end{array}$ & 9.5 & Geologic & $\begin{array}{l}\text { Atwater et al., } \\
2013\end{array}$ \\
\hline & & & 41.84600 & 74.00039 & Chucalen & $\mathrm{O}$ & Geologic & $\begin{array}{l}\text { Garrett et al., } \\
2015\end{array}$ \\
\hline & & & 41.84618 & 74.00065 & Chucalen & $\mathrm{O}$ & Geologic & $\begin{array}{l}\text { Garrett et al., } \\
2015\end{array}$ \\
\hline & & & 41.86663 & 73.82977 & Ancud & 5 & Written & $\begin{array}{l}\text { Saint-Amand, } \\
\text { 1963; } \\
\text { Weischet, } 1963\end{array}$ \\
\hline & & & 41.92361 & 74.00299 & Cocotue & $\mathrm{O}$ & Geologic & $\begin{array}{l}\text { Cisternas et al., } \\
2017\end{array}$ \\
\hline & & & $42.48118^{*}$ & $73.75943 *$ & Castro & $\mathrm{O}$ & Written & $\begin{array}{l}\text { Lagos, 2000; } \\
\text { Lomnitz, 2004; } \\
\text { Cisternas et al., } \\
2005\end{array}$ \\
\hline & & & 42.59949 & 74.11395 & Lake Huelde & $\mathrm{O}$ & Geologic & $\begin{array}{l}\text { Kempf et al., } \\
2017\end{array}$ \\
\hline & & & 44.73059 & 72.68421 & $\begin{array}{c}\text { West of } \\
\text { Puerto Cisnes }\end{array}$ & 2.8 & Written & $\begin{array}{l}\text { Sievers et al., } \\
1963\end{array}$ \\
\hline & & & 45.40258 & 72.82976 & Puerto Aysen & 3 & Written & $\begin{array}{l}\text { Sievers et al., } \\
1963\end{array}$ \\
\hline & & & $45.45655^{*}$ & $72.83443^{*}$ & Chacabuco & $\mathrm{O}$ & Written & $\begin{array}{l}\text { Sievers et al., } \\
1963\end{array}$ \\
\hline
\end{tabular}




\section{History of occupation and settlement in south-central Chile}

The history and timeline of occupation by Spanish Conquistadors in south-central Chile may unfortunately bias the written tsunami historical record. Despite native Mapuche already settled in south-central Chile, only the Spanish kept a documented written record of tsunamigenic earthquake events, which were sent back to Spain in reports. Pre-1580, Spanish settlement was sparse, as there were only a few locations that were fortified and/or occupied. These locations within my study area were Concepción (referred to as Penco post-1843), Arauco, La Imperial (also known as Puerto Saavedra), Corral Bay (also known as Valdivia), and Castro (Guarda, 1970; Campos-Harriet, 1989; Burgos, 1990; Lane, 2015; Cisternas et al., 2012; Cisternas et al., 2017). By 1600, Spanish settlements occupied an outpost in Valparaíso as well, extending the written record to the north (Guarda, 1978). In the 17th century, native Huilliche and Mapuche joined the Dutch to attack the Spanish settlement at Castro and Valdivia, respectively (Lane, 2015). These forts were eventually overtaken, but abandoned by the Dutch due to financial burden. This sequence of events allowed native tribes to establish a stronghold in southern Chile and effectively block out new Spanish settlements between Valdivia and Castro (Lane, 2015). During the $18^{\text {th }}$ century, the Spanish Bourbon dynasty came to power, resettling forts at Valdivia and Castro, and the historical record spatially expanded to also include Spanish coastal fortifications at Talcahuano, Coliumo Bay (also called Dichato), Ancud, Robinson Crusoe Island, and Tenquehuen (in the Aysen region, however abandoned after a couple years; Saavedra Villegas, 1984; Rodríguez, 2006; 
Villanueva et al., 2010; Urbina Carrasco, 2014; Cisternas et al., 2017). Chile officially declared independence from Spain in 1818 and in this time of political changes leading up to the Parliamentary era at the end of the $19^{\text {th }}$ century, settlement continued to expand to locations such as Los Vilos, Constitución, Coronel, Lebu, and Puerto Montt (Collier and Sater, 1996). In the $20^{\text {th }}$ century, more settlements began to establish between the major cities, in addition to resettlement in the Puerto Aysen region, which expanded written records to the southern portion of Chile (Urbina Carrasco, 2014).

\section{Geologic pale otsunami field studies in south-central Chile}

Geologic paleostunami studies and dating methods in south-central Chile are helpful to limit bias in the historical record due to the lack of occupation and availability of writing. As of 2019, there are paleostunami field studies (Figure 1; Table 1) from Quintero (M. Carvajal Pers. Comm., 2019), Lenga (L. Ely Pers. Comm., 2019), Tirúa (Ely et al., 2014), Queule (Matos-Llavona et al., 2019), Quidico (Dura et al., 2017; Hong et al., 2017), Maullín (Cisternas et al., 2005; Atwater et al., 2013), Chucalen (Garrett et al., 2015), Cocotue (Cisternas et al., 2017), and Lake Huelde (on Chiloe Island; Kempf et al., 2017). These paleotsunami deposit studies generally consist of surveying a coastal landscape, identifying a potential tsunami deposit, mapping the extent of a tsunami deposit, and dating the deposit (Pinegina and Bourgeois, 2001; Ely et al., 2014). Tsunamis leave depositional sand layers on the landscape that get preserved with a sharp 
contact over the previous modern soil in certain conditions when deposited in beach swales and marshes (Brill et al, 2011; Nelson et al., 2015). Paleotsunami studies use methods in which tsunami depositional sand layers are identified through the techniques of gouge-coring, pit-digging, trench-digging, lake sediment coring, and augering (Cisternas et al., 2005; Atwater et al., 2013; Ely et al., 2014; Kempf et al., 2017). These sand layers can be used as a proxy for large earthquake events as they provide recurrence histories within the stratigraphy (Pinegina and Bourgeois, 2001). The distribution of a tsunami deposit provides a minimum estimate of inundation distances and runup heights in a specific location (Fujiwara et al., 2000; Scheffers et al., 2008; Peterson et al., 2011).

\section{Historical earthquakes and ts unamis in south-central Chile}

Written accounts and paleotsunami sand deposits document 17 known tsunamigenic earthquakes between 1570 AD and 1960 AD (Figure 1; Table 1). These earthquake events, from earliest to most recent, consist of the: 1570, 1575, 1657, 1730, 1751, 1822, 1835, 1837, 1871, 1871b, 1898, 1906, 1920, 1927, 1928, 1943, and 1960 AD events (FitzRoy, 1839; Milne 1900a; Milne, 1911; Davidson, 1936; Berninghausen, 1962; Sievers et al., 1963; Weischet, 1963; Iida et al., 1967; Lomnitz, 1970; Soloviev and Go, 1975; Instituto Hidrografico de la Armada, 1982; Iida, 1984; Lockridge, 1985; Van Dorn, 1987; Lander and Lockridge, 1989; Monge 1993; Atwater et al., 1999; Lagos, 2000; Lomnitz, 2004; Cisternas et al., 2005; Fritz et al., 2011; Udias et al., 2012; Valenuela, 2012; Wang et al., 2012; Atwater et al., 2013; Ely et al., 2014; Garrett et 1., 2015; Urbina Carrasco et al., 2016; Carvajal et al., 2017; Cisternas et al., 2017; Dura et 
al., 2017; Hong et al., 2017; Kempf et al., 2017). The rupture location of these earthquakes can be defined to varying degrees of accuracy (Lagos, 2000; Lomnitz, 2004; Cisternas et al., 2005; Udias et al., 2012). What follows is a description of what is known about each of these events.

\section{Event}

At 9:00 AM local time on February 8, 1570, an earthquake shook central Chile near from Concepción (present day location of Penco; Soloviev and Go, 1975). Based on the written record from Spanish conquistadors, this earthquake is associated with a major tsunami that was observed mainly in the Concepción Bay region. It was recorded that the ocean along the coast of present day Penco receded nearly ten kilometers before it completely inundated the town. Ships were transported onto dryland, settlements were completely washed away, and over 2000 people were killed in the tsunami (Soloviev and Go, 1975). Tsunami sand deposit candidates observed in Lenga and Tirúa have a radiocarbon age that is constrained within the time period of this earthquake; however, these deposits could be from the 1575 tsunami instead (Ely et al., 2014; Dura et al., 2017; L. Ely Pers. Comm., 2018). The magnitude of the earthquake was estimated to be between M 8.0 and 8.5, which is based on written reports of damages and shaking intensity (Lagos 2000; Lomnitz, 2004). Concepción Bay was the northernmost extent that was recorded as affected by the tsunami (Soloviev and Go, 1975). Tirúa may have been the southernmost extent based on a potential paleotsunami deposit; however, if the 
deposit observed in Tirúa is from the 1575 event (L. Ely Pers Comm., 2018), the tsunami historical record is constrained to the Concepción Bay region.

\section{Event}

At 10:00 AM local time on March 17, 1575, an earthquake caused a major tsunami that was recorded from Concepción (present day location of Penco) to Lake Huelde on Chiloe Island (Lagos, 2000; Lomnitz, 2004; Udias et al., 2012; Kempf et al., 2017). In Valdivia, the tsunami reversed the natural flow of the Valdivia River as it rushed in nearly $25 \mathrm{~km}$ from the mouth. This rise in water knocked down settlements and uprooted trees. In the Valdivia port, two galleon ships were sunk and washed onshore, and $\sim 1500$ deaths occurred, including $~ 100$ native fisherman that drowned near the mouth of the Imperial River (Lomnitz, 1970; Soloviev and Go, 1975). Although the tsunami was observed around the Concepción Bay region, there was no reported information of damage from the tsunami (Soloviev and Go, 1975). Tsunami deposits with radiocarbon ages corresponding to the 1575 event are widespread and found at Maullín, and Cocotue (Cisternas et al., 2017), with two potential tsunami candidates found at Lenga and Tirúa (same deposits noted in the 1570 Event section (L. Ely Pers Comm., 2018). Additionally, the lateral extent of shaking from this earthquake is interpreted as similar to the $M_{w} 9.51960$ earthquake off the coast of Valdivia (Cisternas et al., 2017). The large span of coastline that appears to have been inundated from both the 1575 and 
1960 tsunami suggests that 1575 may have also been an earthquake with a long rupture of great magnitude.

\section{Event}

On March 15, 1657 an earthquake occurred off the coast of Concepción around 8:00 PM local time (Berninghausen, 1962). A report written to Felipe IV in Spain on April $3^{\text {rd }}$, 1657, by Alonso de Solorzano y Velasco, the officer of the Royal Court of Santiago, regarding the state of the nation alludes to a large tsunami (Lomnitz, 2004). This report states that seawater had entered the streets and houses three times at Concepción (present day location of Penco; Lomnitz, 2004). Other written accounts from civilians in Concepción confirm that there were at least three large waves with the largest occurring at least two hours after the earthquake (Berninghausen, 1962; Soloviev and Go, 1975). Much of Concepción suffered heavy damage, especially areas along the river of the eastern part of the town, as there were fewer houses to protect the inner sections from the waves (Instituto Hidrografico de la Armada, 1982). The written documents also estimate the maximum wave height of this tsunami to be $\sim 8 \mathrm{~m}$ high in what is now Penco (Lockridge, 1985). The earthquake was estimated as a M 8.0 based on written reports of damages and shaking intensity (Lockridge, 1985; Lomnitz, 2004; Lagos, 2000). 


\section{Event}

On July 8, 1730, at 4:45 AM local time, an earthquake occurred near the Valparaíso area (Soloviev and Go, 1975). After the shaking, a disruptive tsunami quickly inundated the land with three large flows that "were said to have exceeded that of 1657 " (Lomnitz, 2004). Many towns and fields were reportedly affected. In Concepción (present day location of Penco), nearly two-thirds of the town was destroyed, which consisted of more than 200 houses and buildings (Soloviev and Go, 1975). Only two or three people were killed in this tsunami, "since inhabitants, on first noting the receding sea, ran for the hills from where they watched the destruction of their houses and their property" (Soloviev and Go, 1975). This was the third major tsunami since the town's founding. Recovered documents from an anonymous Jesuit Father also noted flow depth values of $\sim 8 \mathrm{~m}$ at the beach, $\sim 1 \mathrm{~m}$ at the Jesuit convent, $\sim 1.5 \mathrm{~m}$ at the Franciscan convent; unspecified flooding at the hospital, guard, plaza, palace, and cathedral; and that no flooding reached the Mercedarian convent that was situated on higher ground (Carvajal et al., 2017).

Other recovered religious records reported that the tsunami was $7 \mathrm{~m}$ high along the Valparaíso beach, and that flooding had occurred at the Valparaíso Augustinian convent, La Matriz Church, and the Mercedarian convent (Valenuela, 2012; Urbina et al., 2016; Carvajal et al., 2017). Carvajal et al. (2017) conducted a post-tsunami water mark survey three weeks after the 2010 M 8.8 Maule earthquake (which is assumed by Carvajal et al. (2017) to be smaller than 1730) in both Valparaíso and Penco. Correlating 
water heights from the 2010 tsunami, their survey concluded that in Valparaíso, for water to reach Augustinians, La Mariz, and Mercedarians in 1730, the water had to be $\sim 10 \mathrm{~m}$, $\sim 9 \mathrm{~m}$, and $\sim 9 \mathrm{~m}$ high, respectively. In Penco, the 1730 tsunami would be $\sim 3 \mathrm{~m}$ high at the Guard, $\sim 8 \mathrm{~m}$ high at the Jesuit and Mercedarian convents, $\sim 5 \mathrm{~m}$ high at the Fransican and Augustinian convents, $\sim 3 \mathrm{~m}$ high at the hospital, fort, and palace, and $\sim 7 \mathrm{~m}$ high at the cathedral (Carvajal et al., 2017). Written accounts also suggest that the tsunami affected Talcahuano, Corral, and Valdivia (Soloviev and Go, 1975; Instituto Hidrografico de la Armada, 1982; Urbina Carrasco et al., 2016). Tsunami modeling to match the observations noted in these religious texts suggest that this earthquake may have been around M 9.1 to M 9.3 in size (Carvajal et al., 2017).

\section{Event}

On March 25, a little after 1:00 AM local time, a large earthquake was felt near the Concepción area (Soloviev and Go, 1975). About 30 minutes following the shaking, Concepción experienced three large waves, occurring one after another "quite rapidly" (Soloviev and Go, 1975; Lomnitz, 2004). Historical accounts suggest that the main wave was $\sim 10 \mathrm{~m}$ high, and recovered Spanish reports suggest that this event was at least the fourth time that Old Concepción was affected by tsunamis in its history and, perhaps the third time in 20 years (Udias, 2012). As a result, Concepción was rebuilt farther inland from the coast and the old site became the town of Penco (Soloviev and Go, 1975). The tsunami was also observed in Valparaíso. Udias (2012) suggests that the 1751 earthquake 
was similar in size to the 2010 Maule $M_{w} 8.8$ earthquake based on the description of the damage, and the areal extent of the earthquake shaking and tsunami. The 1751 tsunami caused a total of 36 recorded deaths, including the governor of the Fernandez Islands (Udias, 2012). Radiocarbon dates constraining geologic tsunami deposit ages suggest this tsunami also inundated Quidico (Hong et al., 2017) and Tirúa (Ely et al., 2014).

\section{Event}

At 10:30 PM local time on November 19, 1822, the Valparaíso area felt a damaging earthquake with an epicenter about $\sim 15 \mathrm{~km}$ north of Valparaíso (Berninghausen, 1962). The subsequent tsunami in Valparaíso was estimated to be $\sim 3.6$ $\mathrm{m}$ high, based on wave height recordings compared to the ordinary high tide mark on the morning of November 20, 1882 (Soloviev and Go, 1975; Lagos, 2000; Lomnitz, 2004). The sea suddenly rose with the initial wave, which thrust the admiral's ship up to the same level as the customs house, $3.5 \mathrm{~m}$ above the high tide mark, and then suddenly receded, which stranded other small vessels from the harbor inland (Davidson, 1936; Soloviev and Go, 1975). Additional waves also occurred, but never reached the height of the first, and eventually became unnoticeable after 15 minutes (Soloviev and Go, 1975). Near-field tsunami inundation was reported from Quintero in the north to Valdivia in the south; however no inundation accounts were reported in between (Soloviev and Go, 1975). In Quintero, dunes were washed away by the tsunami, numerous rocks were reported to be placed above the water level, and a sunken vessel that could previously 
only be reached by boat (even in low tide) was now $\sim 0.5 \mathrm{~m}$ above the water level due to uplift of the seafloor (Soloviev and Go, 1975). The magnitude of this earthquake was estimated between an M 8.0 and M 8.5 based on shaking intensity and land-level changes (Lagos, 2000; Lomnitz, 2004).

\section{Event}

The February 20, 1835 earthquake occurred at 11:30 AM local time off the coast of Concepción (Soloviev and Go, 1975). Based on shaking intensities derived from written reports, this earthquake was estimated to be M 8.2-8.5 (Lomnitz, 2004). During this event, the water in Concepción Bay darkened and let off an odor of hydrogen sulfide (Soloviev and Go., 1975). About 30 minutes after the initial earthquake, the water in the bay receded leaving the rocks and reefs bare before flooding the bay and transporting vessels to dry land (Soloviev and Go, 1795). Based on written reports, the maximum water height in Concepción Bay at Talcahuano and Quiriquina Island was suggested to be 9 m high (Soloviev and Go., 1975; Lomnitz, 2004). The west shore of the bay experienced uprooted trees, shearing of houses, and movement of everything loose (Soloviev and Go, 1975). After this first wave, a second and third followed which were just as destructive as the first. The tsunami was noted as receding "suddenly" and carrying away many properties and belongings into the ocean (Soloviev and Go, 1975). The tsunami was reported for at least a 1000-km span in the written record from Valparaíso in the north to Castro on Chiloe Island in the south (Soloviev and Go, 1975). 
The Coelemu shore experienced the largest recorded waves, $\sim 24 \mathrm{~m}$, with six inundating waves noted (Soloviev and Go, 1975). Soloviev and Go (1975) collected written evidence of inundation at the Maule River ( $3.5 \mathrm{~m})$, Constitución, Itata River, Coliumo Bay $(\sim 4$ m), Tomé ( $4 \mathrm{~m}$ ), Penco, and Arauco, FitzRoy, (1839) noted inundation at Valdivia, San Vicente/Lenga, Coliumo, and Santa María (where uplift was 2.4-3 m (Wesson et al., 2015)). Inundation also occurred at Isla Mocha (Soloviev and Go., 1975; Lagos, 2000;

Lomnitz, 2004; Wang et al., 2012; Dura et al., 2017), and there is geological evidence of tsunami deposits preserved in coastal environments in Quidico (Hong et al., 2017).

During Charles Darwin's voyage on the Beagle, Darwin and his crew experienced the shaking of the 1835 earthquake on land at Valdivia (FitzRoy, 1839; Lomnitz, 2004). In Valdivia, the river swelled up, the land subsided; and the sea flooded the shore to the high tide mark during low-tide - two people were reported deceased (Soloviev and Go, 1975). Overall, the sea never receded below the low tide mark and the river never fell below its usual level, but flood tides recurred one to two times an hour (Soloviev and Go, 1975).

\section{Event}

In 1837, at 8:05 AM local time on November 7, a large earthquake occurred off Chiloe Island near Ancud and Castro (Soloviev and Go, 1975). The earthquake was estimated from shaking intensities written in the historical record to be between M 8-8.5 (Lagos, 2000; Lomnitz, 2004). Accounts at Ancud suggest that the subsequent tsunami 
caused both the Pudeto River and the strait that separates mainland Chile with Chiloe Island to experience large "tides" that migrated an "enormous" amount of seaweed and mollusks onto the shore (Soloviev and Go 1975). This tsunami largely affected the west side of Chiloe Island with no waves noted as inundating the east side, including at Castro (Berninghausen, 1962). Valdivia was also not affected by the tsunami, but was damaged from the earthquake (Iida, 1984). Additional written accounts in Chile indicate the tsunami inundated Concepción (Cisternas et al., 2005; Maullín (Cisternas et al., 2005), Cocotue (Cisternas et al., 2017), Lake Huelde (Kempf et al., 2017), and 2m in Isla Mercera (Lockridge, 1985). The tsunami was also recorded as damaging in Hawaii, Samoa, the Tonga Islands, and Japan (Iida, 1984). Geological evidence of this tsunami has been found in Cocotue (Cisternas et al., 2017) and Lake Huelde (Kempf et al., 2017).

\section{Event}

On March 25, 1871 at 11:00 AM local time, a strong earthquake occurred north of Constitución at $\sim 35^{\circ} \mathrm{S}$ (Soloviev and Go, 1975). At Valparaíso, the written accounts suggest a tsunami runup height of $1 \mathrm{~m}$ (Lockridge, 1985). This earthquake caused the sea off the coast of Valparaíso to also become "very agitated;" reports from ships in the Valparaíso harbor note they felt shaking (Soloviev and Go, 1975). The written accounts regarding shaking and the localized tsunami event in Valparaíso led to an estimate of $\mathrm{M}$ 7.5 for this earthquake (Lockridge, 1985). 


\section{$1871 b$ Event}

Shortly after midnight local time on December 28,1871 , an earthquake was felt in the Puerto Montt region (Soloviev and Go, 1975). Written accounts suggest that the shaking from the earthquake caused a tent frame to fall, the hillsides to collapse, and the sea to become "very agitated" (Soloviev and Ho, 1975). The tsunami from this earthquake had a 1-m high wave runup in Puerto Montt (Lockridge, 1985).

\section{Event}

At 10:30 PM on July 23, 1898, a relatively small earthquake occurred near Concepción with a noticeable foreshock (Soloviev and Go, 1975). The earthquake was inferred to be M 6.5 (based on the degree of damages, shaking intensity, and where it was felt-Talcahuano, Valparaíso, Santiago ( $100 \mathrm{~km} \mathrm{S-SE} \mathrm{inland} \mathrm{of} \mathrm{Valparaíso),} \mathrm{Coronel,}$ Arauco, Lebu, Concepción, and small settlements inland between Constitución and Lebu (Soloviev and Go, 1975; Milne, 1911; Figure 1). The most serious destruction occurred in Concepción and Talcahuano; about 50 homes suffered some damages from cracked and warped walls, collapsed partitions, and fallen corinces (Soloviev and Go, 1975). Additionally, there was some small damage (no collapses) in Tomé, but three homes completely destroyed in Rere (small settlement SE of Concepción; Soloviev and Go, 1975). A M 6.5 earthquake typically is not large enough to generate a tsunami capable of inundation (Soloviev and Go, 1975). However, there are two conflicting written reports: 
1) A report from the Mayor of Concepción at the time who mentions no activity in the sea and surrounding ports following the earthquake, and 2) a report from Milne (1900 a), suggesting the sea retreated off the coast of Concepción and Talcahuano, making inhabitants "terrified" of a tsunami (Soloviev and Go, 1975). Lockridge (1985) notes a tsunami $0.7 \mathrm{~m}$ high in the Concepción Bay area.

\section{Event}

On August 16, 1906 at 8:40 PM local time, an earthquake with very strong and sudden shaking occurred near Valparaíso (Soloviev and Go, 1975). This earthquake was instrumentally recorded to be M 8.2 (Di Giacomo et al., 2015a; 2018). The shaking from this event was felt in Tacna Peru, Buenos Aires, Argentina, Chiloe Island, and the San Fernandez Islands (Soloviev and Go, 1975). Written accounts record that immediately following the earthquake, there were "strong surges" in the wave current in the bay near Coronel, with "not the slightest wind" (Soloviev and Go, 1975). At Penco and Tomé, the sea retreated $50-60 \mathrm{~m}$ and then rose $\sim 1.5-\mathrm{m}$ high to inundate the coastline sometime between 15 minutes to one hour after the initial earthquake (Soloviev and Go, 1975). Three to four tsunami waves flooded the land (Soloviev and Go, 1975). Also, nearby small coastal settlements around Constitución (such as Buchupureo, Putu, and Llico) reported that "the sea began to seethe or boil," disturbing the wave generation process (Soloviev and Go, 1975). The largest tsunami was recorded farther north than the 
suggested source of the earthquake - written documents note a tsunami 3.6-m high west of Los Vilos (Lagos, 2000).

1920 Event

On August 20, 1920 at 11:30 AM local time, an earthquake occurred near $38.0{ }^{\circ} \mathrm{S}$, $73.5^{\circ} \mathrm{W}$ and was felt from the mouth of the Mataquito River in the north $\left(36.0^{\circ} \mathrm{S}\right)$ to Reloncavi Fjord in the south (41.1 ${ }^{\circ} \mathrm{S}$; Iida et al., 1967; Soloviev and Go, 1975). The size of this earthquake is estimated to be a M 7.0 based on the extent of where it was felt and tsunami generation (Lockridge, 1985; Lagos, 2000). Historical records suggest that this earthquake caused a $1.4 \mathrm{~m}$ wave to inundate the coast west of Guape and at Talcahuano (Lockridge, 1985; Lagos, 2000). At the harbor at Talcahuano, anchored vessels were "violently thrown" by the harsh waves (Berninghausen, 1962).

1927 Event

On November 21, 1927 an earthquake occurred in southern Chile near Puerto Cisnes (Soloviev and Go, 1975). This earthquake was instrumentally recorded to be M 7.2 (Di Giacomo et al., 2015a; 2018). Reports suggest that large waves up to $2.8 \mathrm{~m}$ high formed around $44.6^{\circ} \mathrm{S}, 73^{\circ} \mathrm{W}$ near Puerto Aysen (Lockridge, 1985). Additional reports suggest that water inundated $100-150 \mathrm{~m}$ inland along $45 \mathrm{~km}$ along the coast of the Puerto Aysen region (the number of observations was not listed; Soloviev and Go, 1975; Iida et 
al, 1967). One written account also suggests that a boat and crew were flung into the treetops from a large tsunami wave (Berninghausen, 1962).

1928 Event

At 12:07 AM local time on December 1, 1928 an earthquake sourced in central Chile nearly destroyed both Talca and Constitución: at Talca a fire broke out after the tsunami, which nearly burned down the town, causing 108 casualties, while many buildings collapsed at Constitución (and other neighboring settlements), causing 117 casualties (Soloviev and Go, 1975). This earthquake had an estimated magnitude of 7.7 (Di Giacomo et al., 2015a; 2018). This earthquake event caused waves up to $1.5 \mathrm{~m}$ above the diurnal high tide in Constitución (Soloviev and Go, 1975). Written accounts from sailors aboard the Santa Elisa and Poseidon steamships $\sim 11-13 \mathrm{~km}$ off shore at Constitución observed the waves from considerable distance on a moonlit night. The sailors reported that unusually large waves moved in all directions on the surface for "no more than 112 minutes" (Soloviev and Go, 1975).

\section{Event}

On April 6, 1943, a tsunamigenic earthquake, instrumentally recorded to be a M 8.1, occurred north of Los Vilos with an epicenter at $\sim 30.6^{\circ} \mathrm{S}$ (Lomnitz, 2004; Di Giacomo et al., 2015a; 2018; Figure 1). This earthquake was felt inland at Santiago, Chile and Buenos Aires, Argentina where dishes were reported to break and liquids reported to 
spill in tall buildings (Lomnitz, 2004). This earthquake caused a $1 \mathrm{~m}$ local tsunami at Los Vilos damaging fishing boats (Soloviev and Go, 1975; Lagos, 2000; Lomnitz, 2004;

Lagos, 2000). It was recorded that the tsunami arrived at the tide gauge at Valparaíso 22.3 minutes after the initial earthquake (height of oscillations was $80 \mathrm{~cm}$, average period was $10 \mathrm{~cm}$, duration of oscillations was $\sim 36$ hours). This tsunami also registered at tide gauges in the far-field at Hawaii, California, and Japan (Kushimoto, Hanasaki, and Shimosato). It took approximately 23 hours and 25 minutes for this tsunami to reach the gauge at Kushimoto, Japan (25-cm oscillation amplitude; Soloviev and Go, 1975).

1960 Event

On May 22, 1960, at 3:12 PM local time, the largest instrumentally recorded earthquake in the world to date $\left(M_{w} 9.5\right)$ ruptured in south-central Chile (Soloviev and Go., 1975; Van Dorn, 1987; Di Giacomo et al., 2015a; 2018). Written accounts from Maullín show that some citizens initially mistook the event for nuclear war (Atwater et al., 2013; Atwater et al., 1999). Both the earthquake and tsunami associated with this seismic event were catastrophic and devastated the land: Chile faced approximately $\$ 550$ million in material damages and 1000 deaths following this event (Instituto Hidrografico de la Armada, 1982; Lander and Lockridge, 1989). Also, the Hawaiian Islands, western U.S. coast, and Japan faced approximately \$24 million in damages, $\$ 500,000$ to $\$ 1,000,000$, and $\$ 50$ million in damages, respectively. There were 61 
casualties in Hawaii, and 199 in Japan, where the wave was more than $6 \mathrm{~m}$ high (Lander and Lockridge, 1989).

Locally in Chile, there are countless geological and historical records of the event. Sediment deposits from this event can be found in Tirúa (Ely et al., 2014), Quidico (Dura et al., 2017; Hong et al. 2017), Chucalen (Garrett et al, 2015), Maullín (Atwater et al., 2013; Cisternas et al. 2017), Cocotue (Cisternas et al., 2017), Chiloe Island at Lake Huelde (Kempf et al., 2017), Queule (Matos-Llavona et al., 2019), and Lenga (L. Ely Pers. Comm., 2019). Additionally, written accounts indicate the tsunami had a wave height of: $2.5 \mathrm{~m}$ at Constitución (Iida et al., 1967); Maule River, $5.1 \mathrm{~m}$ at Talcahuano (Fritz et al., 2011), $2 \mathrm{~m}$ at Coronel (Iida et al., 1967), $25 \mathrm{~m}$ at Isla Mocha (Iida, 1984), $11.5 \mathrm{~m}$ at Puerto Saavedra (Weischet, 1963), $8 \mathrm{~m}$ or $15 \mathrm{~m}$ at Mehuín/Missisipi (Weischet, 1963; Iida, 1984), $10 \mathrm{~m}$ at Valdivia (Iida, 1984), $10 \mathrm{~m}$ at Corral (Iida, 1984), $7.5 \mathrm{~m}$ at Muiculpue/Bahía Mansa (Weischet, 1963), 5 m at Ancud (Saint-Amand, 1963; Weischet, 1963), $2.8 \mathrm{~m}$ west of Puerto Cisnes, and $3 \mathrm{~m}$ at Puerto Aysen (Sievers et al., 1963). The tsunami was also reported at Concepción (Iida, 1967), Penco (Carvajal et al., 2017), Arauco (Iida et al., 1967), Lebu (Lagos, 2000), and Chacabuco (Sievers et al., 1963), but specific values of wave height were not defined. 


\section{CHAPTER III}

\section{METHODOLOGY}

\section{Compiling observational values}

To assess potential rupture scenarios, I first compiled a database of the tsunami historical record for my study area (Table 1) from a complete literature review of scientific papers and historical documents that described the effects from all 17 tsunamigenic earthquake events between 1570 and $1960 \mathrm{AD}$. The literature review is summarized in the Background chapter. The database of tsunami observations includes three types of data: 1) written observations of a tsunami with a known wave height recorded in historical documents, 2) written observations of a tsunami with no numerical value recorded in historical documents, and 3) geologic evidence of a buried tsunami sand deposit with no known wave height. How I used the database as a benchmark to compare against my simulated tsunami wave heights is described in more detail in the AIC statistical analysis section below.

\section{GeoClaw simulations}

I created earthquake and tsunami simulations with the open-source tsunami software, GeoClaw version 5.4.1 (http://www.clawpack.org/geoclaw). GeoClaw is a finite-difference model that solves the nonlinear shallow-water equations to calculate tsunami propagation and inundation given specific earthquake and bathymetric input

parameters (George and LeVeque, 2006; MacInnes et al., 2013; Clawpack Development 
Team, 2017). GeoClaw successfully predicts tsunami arrival times and runup heights and is approved by the US National Tsunami Hazard Mitigation Program (Gonzalez et al., 2011). GeoClaw utilizes the standard wave propagation algorithms of Clawpack for a rectangular grid with adaptive mesh refinement to increase the resolution of the simulation when the slope of the water surface exceeds a specific threshold (Berger and LeVeque, 1998; LeVeque et al., 2011). An explanation of the numerical and wave propagation algorithms used to solve the two-dimensional shallow-water equations can be found in LeVeque (2002) and Berger et al. (2011).

GeoClaw propagates a tsunami by solving for the nonlinear shallow water wave equations for a specific time step, while conserving mass and momentum in a Cartesian grid (LeVeque, 2002; LeVeque et al., 2011). Additionally, inundation in GeoClaw is determined by means of calculating water depth values for each cell per time step: dry land cells yield a value of zero, while wet cells yield positive values (LeVeque et al., 2011). In each time step, these water depth values may vary as radial momentum is also accounted for due to a radially symmetric ocean (LeVeque et al., 2011). The inputs necessary to initiate a tsunami in GeoClaw include a specific latitude and longitude domain used on a sphere (a pre-determined value), pre-loaded bathymetry of the coastal region with adjacent onshore topography (discussed in the Bathymetry and topography section below), and seafloor motion, such as from a generated earthquake (LeVeque et al., 2011), discussed in the Seafloor deformation and earthquake generation section below. 


\section{Bathymetry and topography}

For the combined bathymetry and topography of south-central Chile in this research, I used the 30 arc-second resolution from the General Bathymetric Chart of the Oceans (GEBCO; Intergovernmental Oceanographic Commission et al., 2014). Other 30 arc-second data sets were available, such the Scripps Institution of Oceanography Shuttle Radar Topography Mission (SRTM+), and the Estimated Seafloor Topography (ETOPO1), however the GEBCO bathymetry is the most realistic for the Chilean continental shelf (Becerra, 2018).

Additionally, Pan et al. (2010), MacInnes et al. (2013), and Gusman et al. (2014) give examples of how high-resolution bathymetry and topography affect nearshore wave behavior, inundation and runup. For this research, I also simulated the nearshore wave behavior and inundation dynamics at three sites where there is either geological data (Quidico and Tirúa) or well-defined runup in the written record (Puerto Saavedra) of specifically the 1960 tsunami. I used 1/3 arc-second topography grids merged in Arc-GIS to bathymetry based on the existing GEBCO bathymetry from Becerra (2018) for these high resolution simulations. In the case for Tirúa, I modified the merged topography to remove a newly built bridge that acted as a physical seawall rather than a bridge in the river just south of the town. On its own, the GEBCO 30 arc-second bathymetry used elsewhere along the coast is considered too coarse for recreating wave inundation dynamics (c.f. Tang et al., 2009) so only sites with high-resolution topography could be used for my detailed inundation dynamics modeling. 


\section{Seafloor deformation and earthquake generation}

Seafloor deformation is also a required input to initiate a tsunami in GeoClaw; in my study, this deformation is calculated from earthquake rupture scenarios. GeoClaw calculates seafloor motion from slip on discrete subfaults along a fault model of the Chilean subduction zone interface (from the USGS Slab 1.0 model (Hayes et al., 2012). GeoClaw applies the solutions of the Okada (1985) equations, which calculates the deformation of an elastic half-space due to dislocation of an internal rectangular fault element. The combined calculation of seafloor displacement is assumed to directly correspond to water displacement, and thus the initial tsunami (Borrero et al., 2015).

For my Chilean fault model, I created a grid of 76 along-strike by 5 down-dip subfaults, with each subfault corresponding to a $23 \times 23 \mathrm{~km}$ area (Figure 2). Subfault row \#1 is the southernmost subfault along strike and subfault row \#76 is the northernmost subfault along strike. I chose to use $23 \times 23 \mathrm{~km}$ subfaults to evenly subdivide the fault model between the boundaries of the Mocha Fracture Zone (MFZ) at $~ 38.3^{\circ} \mathrm{S}$ (between subfaults 39 and 40) and the Chile Triple Junction at subfault 1 . The subfault grid extended $\sim 900 \mathrm{~km}$ both north and south of the MFZ. The strike of each subfault changes abruptly at the MFZ from $12.5^{\circ}$ in the north to $4.7^{\circ}$ in the south. For each subfault, the rake was inferred to be $90^{\circ}$ to represent a standard thrusting tectonic event (Hayes et al., 2014; Gusman et al., 2014). The dip angle and depth value of each subfault was based from the USGS Slab 1.0 Chilean subduction zone interface (top-center locations of each subfault; Appendix A). 


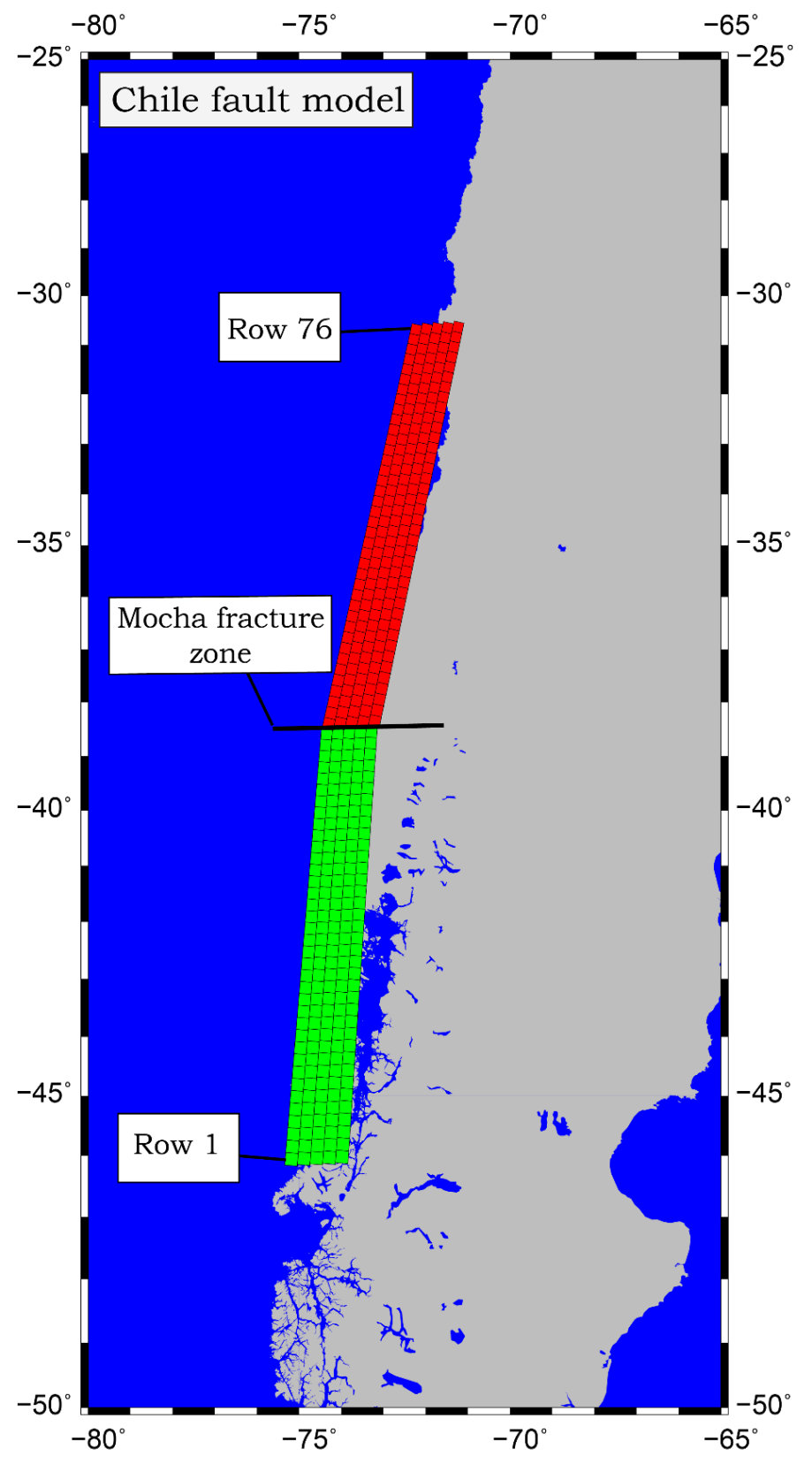

Figure 2: Chilean fault model consisting of $23 \times 23 \mathrm{~km}$ subfaults (76 along-strike subfaults and 5 down-dip subfaults). The change from red subfaults to green subfaults indicates the hypothesized MFZ segment divide along with the change in strike from the northern to southern segment of the fault model $\left(12.5^{\circ}\right.$ on the northern segment to $4.7^{\circ}$ on the southern segment). 
To generate a suite of hypothetical earthquake scenarios, I defined the width, length, and slip between source models, and changed the hypocenter location systematically from south to north. The width of all earthquake scenarios was kept constant at $115 \mathrm{~km}$ despite the full width of the seismogenic subduction zone being closer to 145-150 km (Comte et al., 1994; Haberland et al., 2009; Moreno et al., 2010). I chose this width because Leonard et al. (2010) inferred from the geodetic and thermal data that Chilean subduction zone ruptures are $\sim 25 \%$ less than the full width locked zone. Also, because a deeper part of the rupture zone does not significantly contribute to tsunami generation (Geist, 2002), a 25\% width decrease, representing the upper $~ 115 \mathrm{~km}$ rupture width, will not confine tsunami generation.

I chose values for length and slip of my earthquake scenarios to represent a range of earthquake magnitudes from $M_{w} 8.7, M_{w} 8.9, M_{w} 9.1, M_{w} 9.3$, and $M_{w} 9.5$ (Table 2). The range of earthquake magnitudes was chosen to focus on the largest events that would generate the most pervasive tsunami records (Gusiakov, 2007). I constrained the alongstrike length of rupture by limiting the stress drop to 10-100 bars, a typical stress drop for megathrust earthquakes (Kanamori, 1977). Realistic stochastic (or randomly determined) slip distributions were generated using the von Karman autocorrelation function (ACF) values from Mai and Beroza (2002) that model the stochastic characterizations of the distribution of slip as a spatial random field. I used 3 slip distributions for each $\mathrm{M}_{\mathrm{w}} 8.7$ and 8.9 earthquake location, and 10 variable slip distributions for each $\mathrm{M}_{\mathrm{w}} 9.1,9.3$, and 9.5 earthquake location (Appendix B). These slip distributions were shifted around the 
fault model systematically from south to north, which generated multiple earthquake scenarios at different segments along strike. It is important to note that the total distance in kilometers ruptured along strike for each earthquake size includes significant slip tapering from the areas of high slip.

By incrementally shifting the central subfault of each slip distribution latitudinally, I created 423 hypothetical earthquake source models. The naming scheme for these models contains three variables: 1) the along-strike subfault number of the central subfault, 2) the moment magnitude of the earthquake, and 3) the random slip distribution number (1-3 or 1-10). For example, earthquake model 09_87_1 represents a $M_{\mathrm{w}} 8.7$ earthquake corresponding with slip distribution \#1 with subfault row 9 at its center. Because $\mathrm{M}_{\mathrm{w}} 9.5$ earthquakes rupture the entire fault model area, all have a central subfault number of 38.

In addition to the random slip distributions, I created other earthquake models for comparison. These include centrally located uniform slip models for each earthquake magnitude (38_87_X, 38_89_X, 38_91_X, 38_93_X, and 38_95_X). I determined slip for these models by averaging the slip values for all rupturing subfaults within the fault model. I also created a source model from the solution for the 1960 earthquake event based off surface deformation from Barrientos and Ward (1990). Despite the Barrientos and Ward (1990) solution having a seismic moment equivalent to a $M_{w} 9.3$ earthquake, my "Barrientos slip" earthquake has a seismic moment equivalent to a $M_{w} 9.0$ event. This is because I determined slip for this source by contouring and scaling their values of 
proposed slip to my fault model. This method caused a portion of slip from the Barrientos and Ward (1990) solution to be omitted in my earthquake source since the proposed slip was situated too deep in the subduction zone, and beyond my fault model, to contribute to tsunami generation (Geist, 2002).

Table 2: Characteristics of hypothetical earthquake simulations.

\begin{tabular}{|l|l|l|l|l|l|l|}
\hline Magnitude & $\begin{array}{l}\text { Subfaults } \\
\text { ruptured } \\
\text { along } \\
\text { strike }\end{array}$ & $\begin{array}{l}\text { Subfaults } \\
\text { ruptured } \\
\text { along dip }\end{array}$ & $\begin{array}{l}\text { Total } \\
\text { subfaults } \\
\text { ruptured }\end{array}$ & $\begin{array}{l}\text { Distance } \\
\text { along } \\
\text { strike } \\
\text { ruptured } \\
(\mathbf{k m})\end{array}$ & $\begin{array}{l}\text { Distance } \\
\text { ruptured } \\
\text { down dip } \\
(\mathbf{k m})\end{array}$ & $\begin{array}{l}\text { Stress } \\
\text { drop } \\
(\mathbf{b a r s})\end{array}$ \\
\hline 8.7 & 18 & 5 & 90 & 414 & 115 & 15.33 \\
\hline 8.9 & 36 & 5 & 180 & 828 & 115 & 15.29 \\
\hline 9.1 & 72 & 5 & 360 & 1656 & 115 & 15.25 \\
\hline 9.3 & 72 & 5 & 360 & 1656 & 115 & 30.43 \\
\hline 9.5 & 76 & 5 & 380 & 1748 & 115 & 57.53 \\
\hline
\end{tabular}

\section{Simulated tide gauge locations}

Using my literature review of all historical tsunami-producing earthquakes between 1570 and 1960, I created 47 tide gauges as locations to record waveforms in tsunami simulations (Table 3). Each tide gauge position corresponds to either observations in the historical record or geologic deposits of buried sands, although tide gauges are located offshore of those points, near the shoreline, at a water depth of 0 to $10 \mathrm{~m}$. Because the resolution of the GEBCO bathymetry/topography was only 30 arcseconds, I placed all tide gauges in the ocean for three reasons: (1) the oversimplification (i.e. averaging) of topography to 30 arc-second resolution meant that many observation sites were higher elevation in the simulations than reality and rivers or valleys narrower 
than 30" were often missing from simulations, (2) a gauge on land could not record a simulated wave height lower than the gauge elevation, and (3) 30 arc-second resolution is considered too coarse for reliable modeling of coastal inundation processes (Pan et al., 2010). To insure the bathymetric/topographic grid resolution stayed consistent at each tide gauge over the duration of the simulation, I used 15 arc-second boxes of refinement around clusters of gauges ( 20 boxes total), subdivided from the 30 arc-second GEBCO bathymetry (Appendix C).

Table 3: Tide gauge location information for GeoClaw models. Shoreline longitude/latitude is the position used in simulations.

\begin{tabular}{|c|c|c|c|c|c|}
\hline $\begin{array}{c}\text { Gauge } \\
\text { number }\end{array}$ & $\begin{array}{c}\text { General } \\
\text { location }\end{array}$ & $\begin{array}{c}\text { Observation } \\
\text { longitude }\end{array}$ & $\begin{array}{c}\text { Observation } \\
\text { latitude }\end{array}$ & $\begin{array}{c}\text { Shoreline } \\
\text { longitude }\end{array}$ & $\begin{array}{c}\text { Shoreline } \\
\text { latitude }\end{array}$ \\
\hline 1000 & $\begin{array}{c}\text { Valparaíso } \\
\text { Region }\end{array}$ & -71.63205 & -33.03631 & -33.04365 & -33.03631 \\
\hline 1001 & $\begin{array}{c}\text { Valparaíso } \\
\text { Region }\end{array}$ & -71.62942 & -33.03948 & -71.62859 & -33.04365 \\
\hline 1002 & $\begin{array}{c}\text { Valparaíso } \\
\text { Region }\end{array}$ & -71.61034 & -33.04254 & -71.61034 & -33.04254 \\
\hline 1003 & $\begin{array}{c}\text { Valparaíso } \\
\text { Region }\end{array}$ & -71.60727 & -33.04879 & -71.59477 & -33.03254 \\
\hline 1004 & $\begin{array}{c}\text { N of } \\
\text { Constitución }\end{array}$ & -72.21120 & -35.10968 & -72.21120 & -35.10968 \\
\hline 1005 & $\begin{array}{c}\text { Maule River } \\
\text { Mouth }\end{array}$ & -72.42500 & -35.31588 & -72.42500 & -35.31588 \\
\hline 1006 & Constitución & -72.41130 & -35.31632 & -72.41963 & -35.31215 \\
\hline 1008 & $\begin{array}{c}\text { Dichato/ } \\
\text { Coliumu Bay }\end{array}$ & -72.93624 & -36.54621 & -72.94457 & -36.53788 \\
\hline 1009 & Tomé & -72.96333 & -36.61774 & -72.96708 & -36.63024 \\
\hline 1010 & S of Tomé & -73.05999 & -36.63735 & -73.05687 & -36.63735 \\
\hline 1011 & Talcahuano & -73.10445 & -36.72474 & -73.10445 & -36.72057 \\
\hline 1012 & $\begin{array}{c}\text { Concepción } \\
\text { Bay }\end{array}$ & -73.05561 & -36.73471 & -73.05561 & -36.73054 \\
\hline 1013 & $\begin{array}{c}\text { San Vicente } \\
\text { Bay }\end{array}$ & -73.16166 & -36.73471 & -73.15708 & -36.72638 \\
\hline
\end{tabular}




\begin{tabular}{|c|c|c|c|c|c|}
\hline $\begin{array}{c}\text { Gauge } \\
\text { number }\end{array}$ & $\begin{array}{l}\text { General } \\
\text { location }\end{array}$ & $\begin{array}{c}\text { Observation } \\
\text { longitude }\end{array}$ & $\begin{array}{c}\text { Observation } \\
\text { latitude }\end{array}$ & $\begin{array}{l}\text { Shoreline } \\
\text { longitude }\end{array}$ & $\begin{array}{c}\text { Shoreline } \\
\text { latitude }\end{array}$ \\
\hline 1014 & Penco & -72.99081 & -36.73617 & -72.99914 & -36.72784 \\
\hline 1015 & Lenga & -73.17249 & -36.76566 & -73.16522 & -36.77093 \\
\hline 1022 & Coronel & -73.14661 & -37.03602 & -73.15494 & -37.03602 \\
\hline 1023 & Arauco Bay & -73.42752 & -37.23425 & -73.42335 & -37.23425 \\
\hline 1024 & $\begin{array}{c}\text { Arauco } \\
\text { Province }\end{array}$ & -73.54026 & -37.89854 & -73.54026 & -37.89854 \\
\hline 1025 & $\begin{array}{c}\text { Arauco } \\
\text { Province }\end{array}$ & -73.47869 & -37.99779 & -73.48369 & -37.99779 \\
\hline 1026 & $\begin{array}{c}\text { Arauco } \\
\text { Province }\end{array}$ & -73.48082 & -38.01159 & -73.48082 & -38.01159 \\
\hline 1027 & $\begin{array}{c}\text { Arauco } \\
\text { Province }\end{array}$ & -73.46170 & -38.08409 & -73.46170 & -38.08409 \\
\hline 1028 & Quidico & -73.47727 & -38.22961 & -73.47727 & -38.23294 \\
\hline 1029 & Quidico & -73.49290 & -38.25070 & -73.49290 & -38.24237 \\
\hline 1052 & Quidico & -73.49333 & -38.25364 & -73.49333 & -38.24531 \\
\hline 1053 & Tirúa & -73.53700 & -38.32806 & -73.53908 & -38.32806 \\
\hline 1054 & Tirúa & -73.48758 & -38.34447 & -73.54591 & -38.34447 \\
\hline 1055 & Isla Mocha & -73.86740 & -38.37465 & -73.87052 & -38.37882 \\
\hline 1056 & Puerto Saavedra & -73.47045 & -38.71792 & -73.46712 & -38.71792 \\
\hline 1058 & Puerto Saavedra & -73.42675 & -38.78532 & -73.42258 & -38.78532 \\
\hline 1059 & North of Tolten & -73.28660 & -39.12751 & -73.28660 & -39.12751 \\
\hline 1060 & Tolten & -73.24019 & -39.28183 & -73.23603 & -39.28183 \\
\hline 1061 & Queule & -73.23197 & -39.35852 & -73.22780 & -39.35852 \\
\hline 1062 & Mehuín & -73.24635 & -39.42700 & -73.24635 & -39.42700 \\
\hline 1066 & Valdivia Region & -73.42598 & -39.88387 & -73.41765 & -39.88387 \\
\hline 1067 & Valdivia Region & -73.39495 & -39.89045 & -73.39912 & -39.89045 \\
\hline 1068 & Valdivia Region & -73.59558 & -39.94386 & -73.59558 & -39.94386 \\
\hline 1069 & Bahía Mansa & -73.71390 & -40.53544 & -73.74307 & -40.53544 \\
\hline 1070 & Puerto Montt & -72.96388 & -41.48602 & -72.95222 & -41.48602 \\
\hline 1072 & Maullín & -73.67817 & -41.57341 & -73.67817 & -41.53591 \\
\hline 1100 & Cocotue Region & -74.00065 & -41.84618 & -74.01731 & -41.88785 \\
\hline 1101 & N Chiloe Island & -74.04832 & -42.06002 & -74.04832 & -42.06002 \\
\hline 1102 & Lake Huelde & -74.12694 & -42.63499 & -74.12694 & -42.63499 \\
\hline 1103 & S Chiloe Island & -74.19680 & -42.86273 & -74.19680 & -42.86273 \\
\hline 1104 & $\begin{array}{c}\text { West of Puerto } \\
\text { Cisnes }\end{array}$ & -72.68421 & -44.73059 & -72.70921 & -44.72976 \\
\hline 1105 & Puerto Aysen & -72.82976 & -45.40258 & -72.84226 & -45.40258 \\
\hline 1106 & Campiche & -71.49623 & -32.75048 & -71.46517 & -32.75595 \\
\hline
\end{tabular}




\begin{tabular}{|c|c|c|c|c|c|}
\hline $\begin{array}{c}\text { Gauge } \\
\text { number }\end{array}$ & $\begin{array}{c}\text { General } \\
\text { location }\end{array}$ & $\begin{array}{c}\text { Observation } \\
\text { longitude }\end{array}$ & $\begin{array}{c}\text { Observation } \\
\text { latitude }\end{array}$ & $\begin{array}{c}\text { Shoreline } \\
\text { longitude }\end{array}$ & $\begin{array}{c}\text { Shoreline } \\
\text { latitude }\end{array}$ \\
\hline 1107 & Los Vilos & -71.51217 & -31.91211 & -71.51158 & -31.90929 \\
\hline
\end{tabular}

\section{AIC statistical analys is}

To determine how well each simulation matched observed historical tsunamis, I compared the maximum wave heights simulated at each tide gauge with my tsunami observation database using the Akaike Information Criterion (AIC) statistical equations (Burnham and Anderson, 2002). This analytical method uses the known historical observation and paleotsunami deposit database to select tsunami simulations that correlate better with what is known in the historical record. AIC allows for the comparison between simulations by analyzing the residual sum of squares (RSS) between the modeled and observed wave heights for each simulation at every tide gauge (Burnham and Anderson, 2002). Earthquake source models that have different rupture characteristics (e.g. position along strike and distribution of slip) will generate different waveform data with varying RSS. The AIC equations enable me to identify a suite of statistically significant simulations based on how closely modeled wave heights match the inputted known wave heights at all locations (Burnham and Anderson, 2002). AIC provides an effective, yet simple method for selecting an estimated best approximating model and set of "good models" through this concept of variable selection and marrying information theory with mathematical statistics, as opposed to hypothesis testing (Burnham and Anderson, 2002). 
The equations used in the analysis are after Burnham and Anderson (2002):

$$
\begin{aligned}
& \sigma^{2} \frac{\Sigma \epsilon i^{2}}{n}(\mathrm{RSS}, \text { Residual sum of Squares) } \\
& A I C=n * \log _{10}\left(\sigma^{2}\right)+2 \mathrm{k}
\end{aligned}
$$

where $n$ is the number of observations and $k$ is the number of subfaults plus one (total number of estimated regression parameters). The AIC equation accounts for the differences in rupture lengths $(\mathrm{k})$ in the different earthquake source models (e.g. $\mathrm{M}_{\mathrm{w}} 8.7$ source models rupture 90 subfaults while $\mathrm{M}_{\mathrm{w}} 9.5$ rupture 380 subfaults). However, to account for the small sample sizes of observations, a second order correction to the AIC formula, $\mathrm{AIC}_{\mathrm{c}}$, is needed:

$$
\mathrm{AIC}_{\mathrm{c}}=A I C+\frac{2 k(k+1)}{n-k-1}
$$

The AIC equations require definitive wave height values from the historical and geologic record to be used for comparison of simulated wave heights. This requirement poses a problem when conclusive wave height data are absent within the written record. Thus, to solve the AIC equations, I interpolated probable wave heights for coastal sites with undefined wave heights (defined in Appendix D) by averaging the range of potential wave heights to that could produce observation records. These wave heights were defined on a site-specific and event-specific basis. I used a combination of strategies to estimate the minimum and maximum wave height needed for a tsunami to be observed at a site before the observation description would have likely changed how the tsunami was described: 1) elevation profiles from Google Earth, 2) previous literature on paleotsunami studies, which told me locations that should have been inundated (Ely et al., 2014; 
Garrett et al., 2015; Cisternas et al., 2017; Dura et al., 2017; Hong et al., 2017; Kempf et al., 2017; Carvajal Pers. Comm., 2019; Matos-Llavona et al., 2019), 3) written reports of damages (and locations) associated with each respective event, and 4) comparisons to other recorded wave heights that occurred at the relatively same location in other historical tsunamis. The resulting range of inferred average wave heights are uncertain, but I accounted for this by calculating the standard deviation between the possible maximum and minimum wave heights and weighting the averages by each respective standard deviation. For example, coastal sites with large differences between a possible maximum and minimum wave height have less weight in the RSS calculation than sites that have smaller ranges. To make sure that coastal sites with documented wave heights were weighted the strongest in the statistical analysis, I considered these heights to have the minimum amount of uncertainty (standard deviation of $0.5 \mathrm{~m}$ ) of all observations.

\section{Determining a "good fit"}

$\mathrm{AIC}_{\mathrm{c}}$ values are typically positive, although can range from large negative numbers (due to computing AIC from regression statistics) to numbers as high as 340,000 (Burnham and Anderson, 2002). In this statistical analysis, the $\mathrm{AIC}_{\mathrm{c}}$ values can be shifted negative depending on the number of observations present for each earthquake scenario. However, to assess whether a model is fits well or not, it is not the absolute size of the $\mathrm{AIC}$ value, but rather the difference between the relative $\mathrm{AIC}_{\mathrm{c}}$ values from the $\mathrm{AIC}_{\mathrm{c} \text { min }}$, known as $\Delta_{\mathrm{i}}\left(\Delta_{\mathrm{i}}=\mathrm{AIC}_{\mathrm{c} i}-\mathrm{AIC}_{\mathrm{c} \text { min }}\right)$, that is important (Burnham and Anderson, 2002). 
Therefore, $\mathrm{AIC}_{\mathrm{c}}$ values are only comparable relative to other $\mathrm{AIC}_{\mathrm{c}}$ values in the same model set. An individual $\mathrm{AIC}_{\mathrm{c}}$ value is not interpretable or useful; Burnham and Anderson (2002) suggest that following levels of empirical support based on the $\Delta_{\mathrm{i}}$ for $A I C_{\mathrm{c} i}$ :

- $0-2=$ Substantial

- $\quad 4-7$ = Considerably less

- $\quad>10=$ Essentially none

Because models with $\Delta_{\mathrm{i}}>10$ fail to describe substantial explainable variation within the wave height data, I can omit source models that have $\Delta_{\mathrm{i}}$ values greater than 10 as not being a reasonable solution for the rupture characteristics of a historically observed event.

The accuracy of the AIC statistical analysis is evaluated through calculating the root mean square error (RMSE) value of the statistically significant earthquake solutions. The RMSE value uses the same weighted values from the RSS and AIC equations and declares an absolute measure of fit with lower values indicating better fit (e.g. a RMSE value of $1 \mathrm{~m}$ indicates that the mean modeled wave height is either $1 \mathrm{~m}$ higher or lower than the observed wave height in the historical record). This RMSE equation acts as a validity check within the AIC model selection process:

$$
R M S E=\sqrt{\frac{\sum_{i=1}^{n}(X \mathrm{obs}, i-X m o, i)^{2}}{n}}
$$

where Xobs is the observed wave height, Xmo is the modeled wave height, and $n$ is the number of tide gauges. Theoretically, the spread of $\mathrm{AIC}_{\mathrm{c}}$ values should yield both low and high RMSE values. Therefore, the RMSE values validate the overall pool of 
earthquake source models and define both "good-fitting" and "poor-fitting" solutions in the AIC analysis.

For a tsunami simulation to be listed as properly matching 1960 tsunami inundation at Tirúa, Quidico, and Puerto Saavedra, I required simulated inundation to match previously documented inundated areas (Figure 3). The inundated areas at Quidico were based on Hong et al. (2017), and those at Tirúa were based on Ely et al. (2014). Since no geologic evidence has been measured to date at Puerto Saavedra, wave height accounts recorded in the historical record were used to match tsunami simulations: maximum tsunami height inundating the village was measured to be 7-8 $\mathrm{m}$ (Sievers et al., 1963) and $11.5 \mathrm{~m}$ was recorded at the southern corner of the bay (Weischet, 1963).
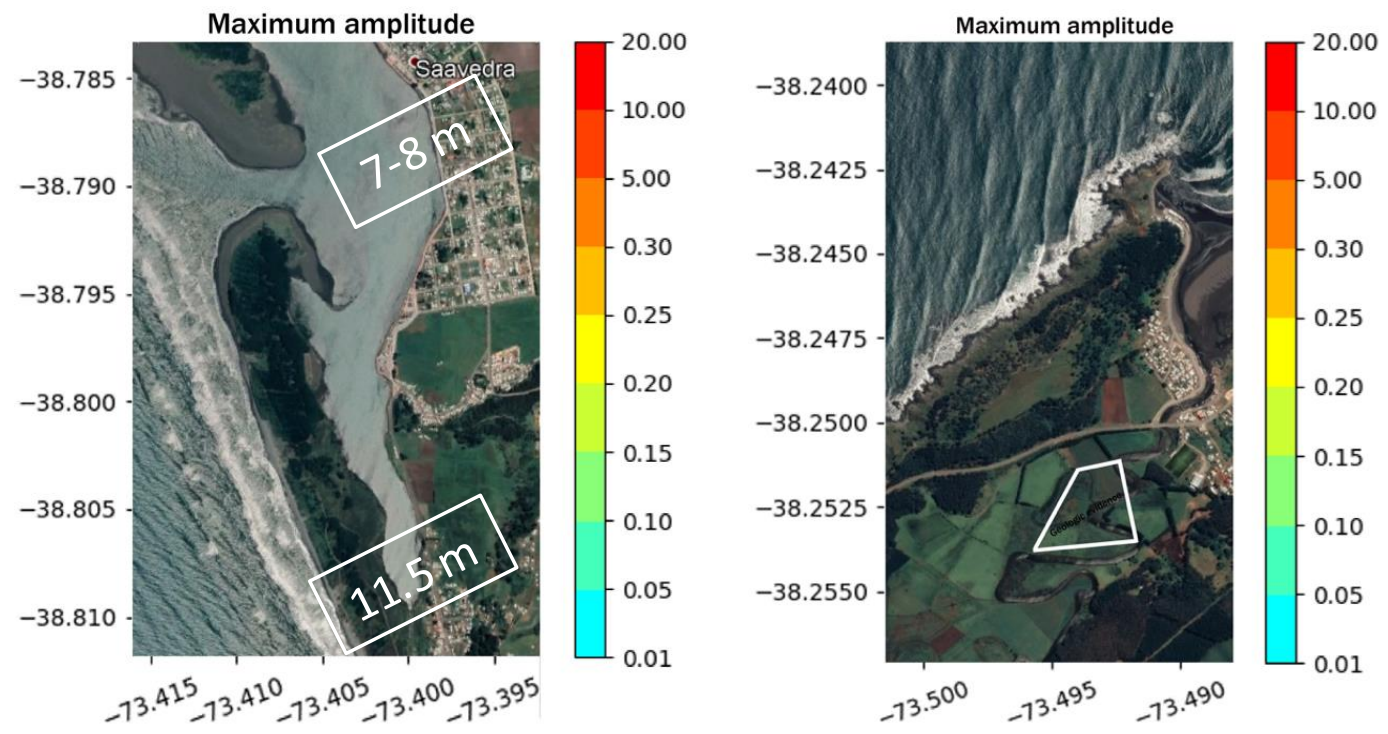

Figure 3: The three locations where $1 / 3$ arc-second bathymetry was used to simulate inundation dynamics: left) Puerto Saavedra, right) Quidico, and bottom) Tirúa. White boxes indicate areas where geologic evidence was found for the 1960 tsunami. No geologic evidence has been studied at Puerto Saavedra. 


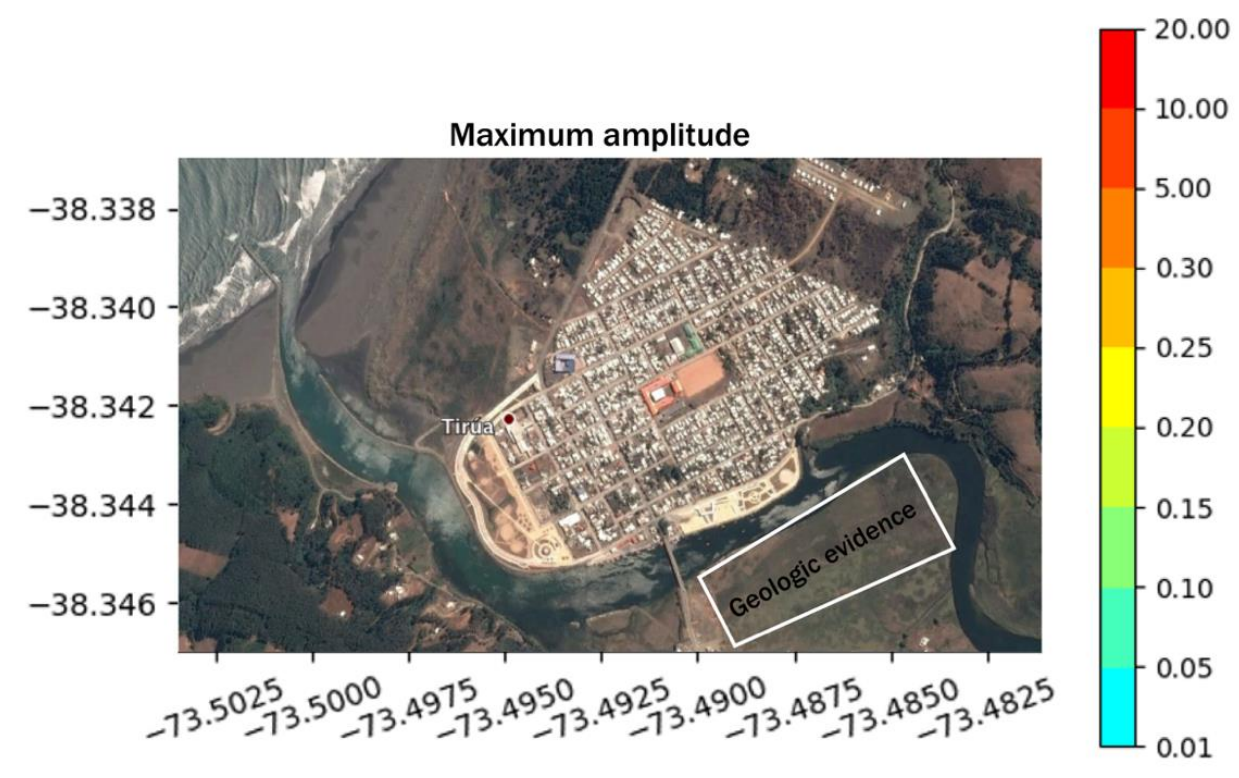

Figure 3: Continued.

\section{Using seafloor de formation to refine "best-fit" model selection}

The AIC equations can be used as a great method for eliminating source models, however additional methods are needed to improve the suite of models to determine more geologically probable fits. One of these methods available is the seafloor deformation data. Because we assume that the water column moves as an incompressible fluid based on Newtonian physics (Berger et al., 2011), seafloor deformation correlates directly to displaced water. Therefore, the absolute values of seafloor deformation for each cell in the subfault model equals the volume of water displaced. I calculated the area of water displacement in degrees from the seafloor deformation of all earthquakes with $\mathrm{AIC}_{\mathrm{c}}$ values <10 for the 1960 earthquake, then converted degrees to meters using Haversine 
equations. I then determined the total volume displaced by multiplying this value $\left(\mathrm{m}^{2}\right)$ by the water displacement each cell in the source model. Knowing the volume of displaced water in each source model allows for greater insight towards how each slip distribution influences different waveform and inundation patterns. 


\section{CHAPTER IV \\ HISTORICAL RESULTS \\ 1570 tsunami simulations}

The 1570 event $\mathrm{AIC}_{\mathrm{c}}$ analysis used three tide gauges (Appendix D); one correlating to an observation in the written record (Penco), and two possible accounts within the geologic record that cannot be ruled out, but either correspond to the tsunami from this event or the 1575 event (Tirúa and Lenga; Table 1). Based on the $\mathrm{AIC}_{\mathrm{c}}$ statistical analysis of the three gauges, the $\Delta_{\mathrm{i}}$ of all ranged from 0 to 29.23 values and 39 models yielded a $\Delta_{\mathrm{i}}$ value less than 7 (Appendix $\mathrm{E}_{1}$ ). Of these 39 earthquake models, four yielded a $\Delta_{\mathrm{i}}$ value less than 2.0, indicating "substantial fits" (Figure 4). Better fitting earthquake source models for the 1570 event appear to rupture a greater area on the northern segment of the Chilean subduction zone (e.g. 46_87_3). The top four earthquake source models, 38_91_3, 39_91_3, 43_89_3, and 46_87_3, all had an average root mean square error (RMSE) value less than $0.31 \mathrm{~m}$. The $\mathrm{M}_{\mathrm{w}} 9.3$ and $\mathrm{M}_{\mathrm{w}} 9.1$ earthquake source models showed similar concentrations of high slip located at $\sim 36^{\circ} \mathrm{S}$ and $\sim 40^{\circ} \mathrm{S}$, while the smaller $\mathrm{M}_{\mathrm{w}} 8.7$ source model showed a single high slip concentration at $\sim 37.5^{\circ} \mathrm{S}$ (Figure 5). 


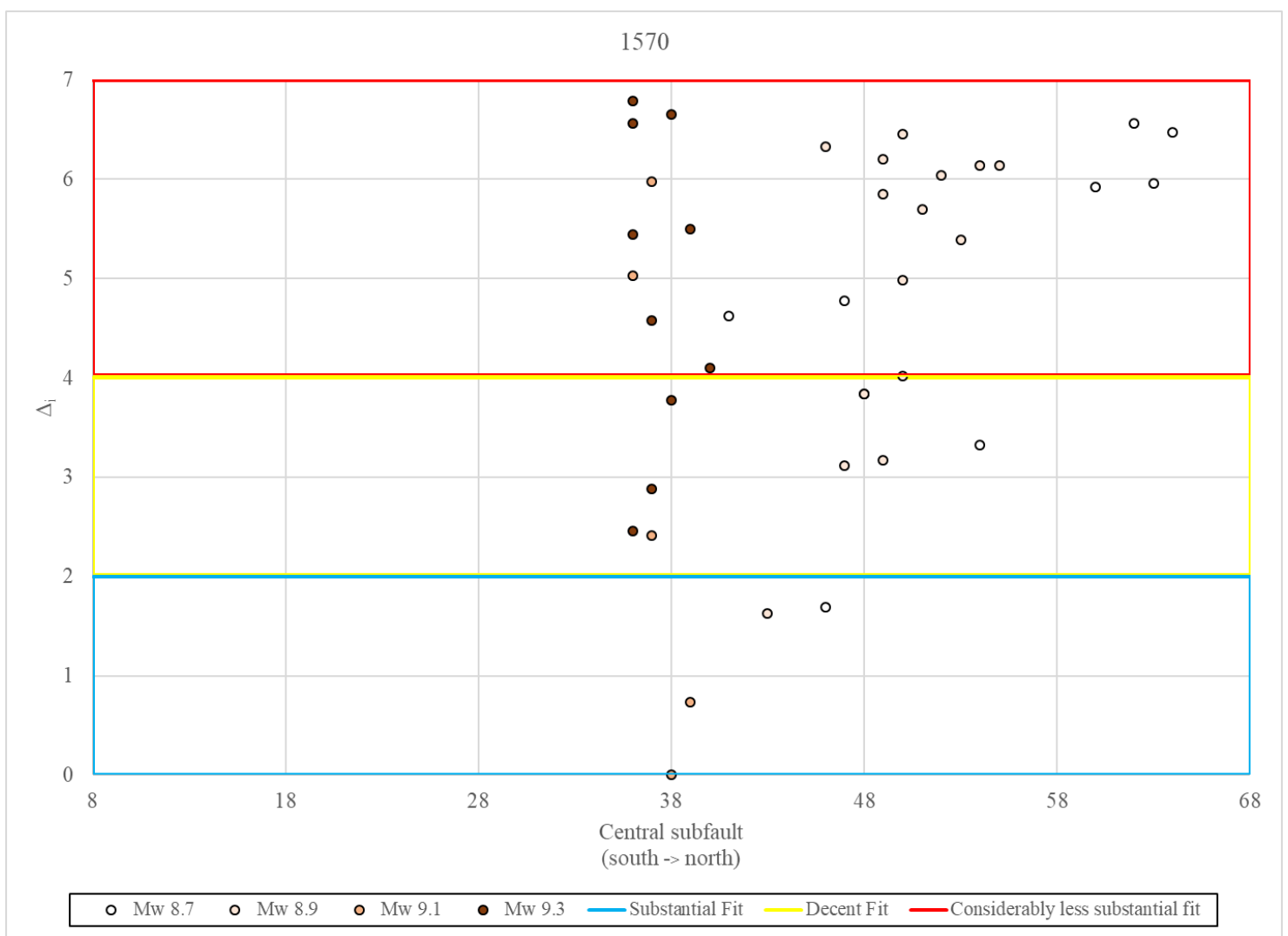

Figure 4: The 39 earthquake source models that yielded a $\Delta_{\mathrm{i}}<7.0$ when compared against the 1570 historical data. Tsunami simulations from the earthquake source models 38_91_3, 39_91_3, 43_89_3, and 46_87_3 represent a statistically substantial fit based on the historical tsunami data available for the 1570 event. 

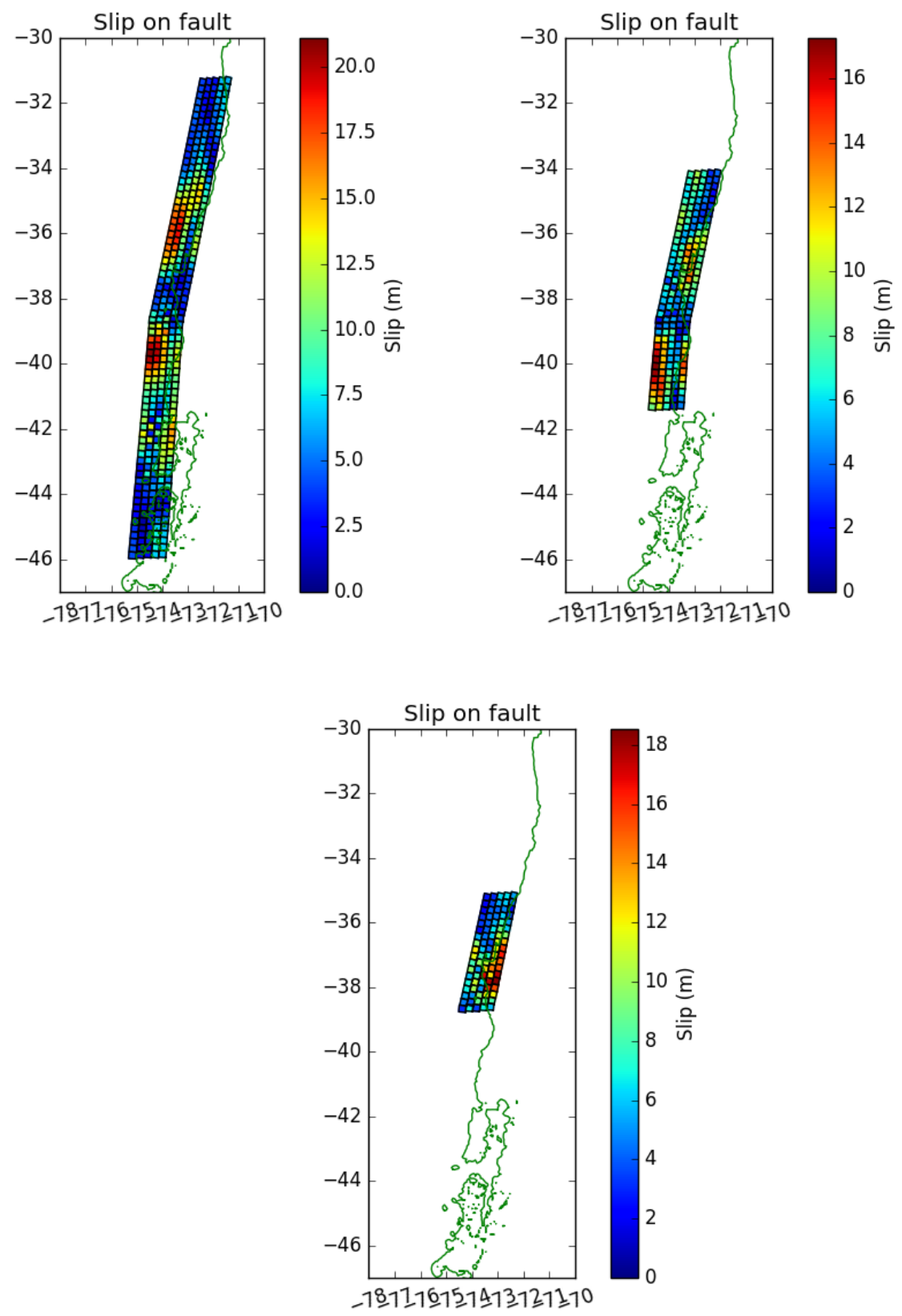

Figure 5: Potential rupture scenarios of three statistically significant source models, which yielded $\Delta_{\mathrm{i}}$ values that suggest a substantial fit based on the AIC equations for the 1570 event: left) model 38_91_3, right) 43_89_3, and bottom) model 46_87_3. 


\section{5 tsunami simulations}

The $1575 \mathrm{AIC}_{\mathrm{c}}$ analysis used 12 tide gauges (Appendix D). Five tide gauges correlated to observations in the written record (Penco, two around Puerto Saavedra, Valdivia, Chucalen), while the other seven gauges correlated to accounts within the geologic record (Lenga, two around Tirúa, Maullín, Cocotue, Castro, and Lake Huelde; Table 1). Similar to 1570, the gauges at Lenga and Tirúa are included in this analysis as they cannot be ruled out for this event. Based on the $\mathrm{AIC}_{\mathrm{c}}$ statistical analysis with these gauges, the $\Delta_{\mathrm{i}}$ of all earthquake source models ranged from 0 to 72.36 and two yielded a $\Delta_{\mathrm{i}}$ value less than 7 (Appendix $\mathrm{E}_{2}$ ). These models were 39_93_8 and 40_93_8 and both yielded a "substantially" significant $\Delta_{\mathrm{i}}$ value (less than 2.0; Figure 6). These top two models also had a RMSE value less than $0.12 \mathrm{~m}$, however, all models had a RMSE within $1.83 \mathrm{~m}$. The region of high slip concentration for the top two models were similar as they were only offset by $23 \mathrm{~km}$. Both models had a maximum, deep slip at $\sim 39^{\circ} \mathrm{S}$ (Figure 7). 


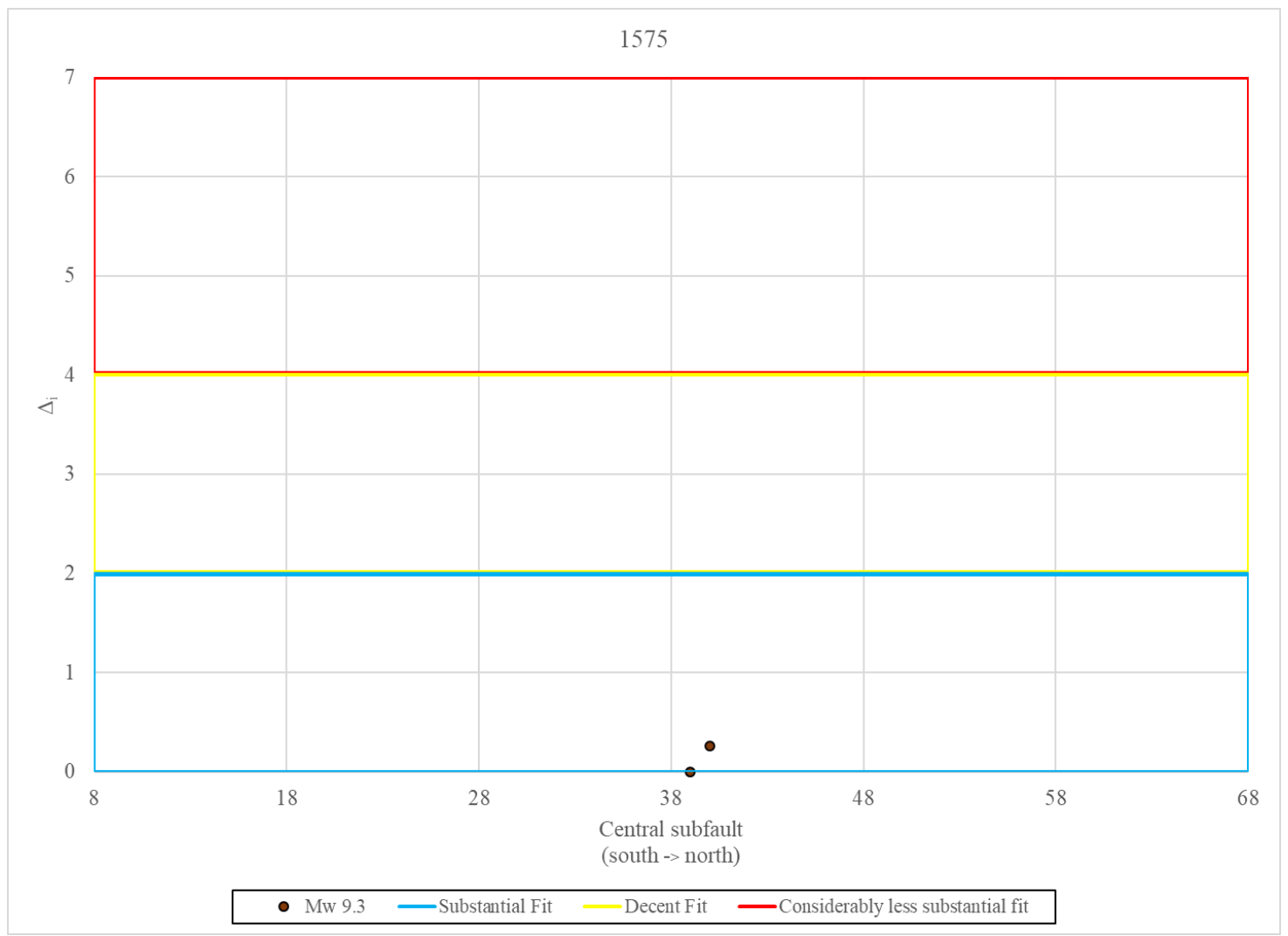

Figure 6: The two earthquake source models that yielded a $\Delta_{\mathrm{i}}<7.0$ when compared against the 1575 historical data. Tsunami simulations from the earthquake source model 39_93_8 and 40_93_8 represent statistically substantial fits based on the historical tsunami data available for the 1575 event. 

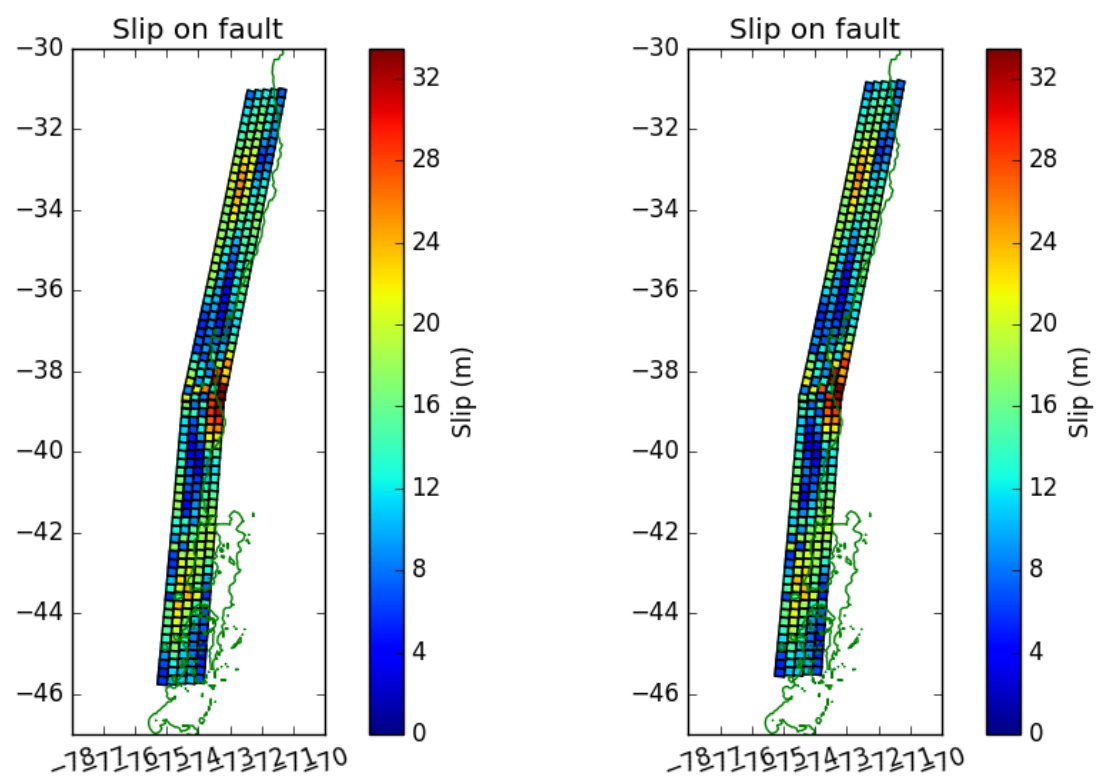

Figure 7: Potential rupture scenarios that were statistically significant, which yielded $\Delta_{\mathrm{i}}$ values that suggest a substantial fit based on the AIC equations for the 1575 event: left) model 39_93_8, right) model 40_93_8.

\section{7 tsunami simulations}

There was only one observation for the 1657 event (a written record in Penco), therefore only one tide gauge could be used for the $\mathrm{AIC}_{\mathrm{c}}$ statistical analysis (Appendix D; Table 1). The $\Delta_{\mathrm{i}}$ of all 423 earthquake source models at this one gauge ranged from 0 to 5.61. Thus, all 423 earthquake source models yielded a $\Delta_{\mathrm{i}}$ value less than 7 (Figure 8; Appendix $E_{3}$ ), 11 of which gave a $\Delta_{i}$ value less than 2.0, indicating "substantial fits". These models were 36_93_3, 40_93_10,40_93_9, 38_95_1, 37_93_3, 39_93_10, 39_93_9, 51_87_1, 38_95_4, 36_93_10, and 38_93_9. The earthquake source models with a $\Delta_{\mathrm{i}}$ value less than 2.0 had RMSE values that ranged from $1.84 \mathrm{~m}$ to $4.95 \mathrm{~m}$. The 
region of high slip for these models vary greatly (Figure 9). See the Discussion chapter for the interpretation of all results having such close $\Delta_{\mathrm{i}}$ values and only using one tide gauge.

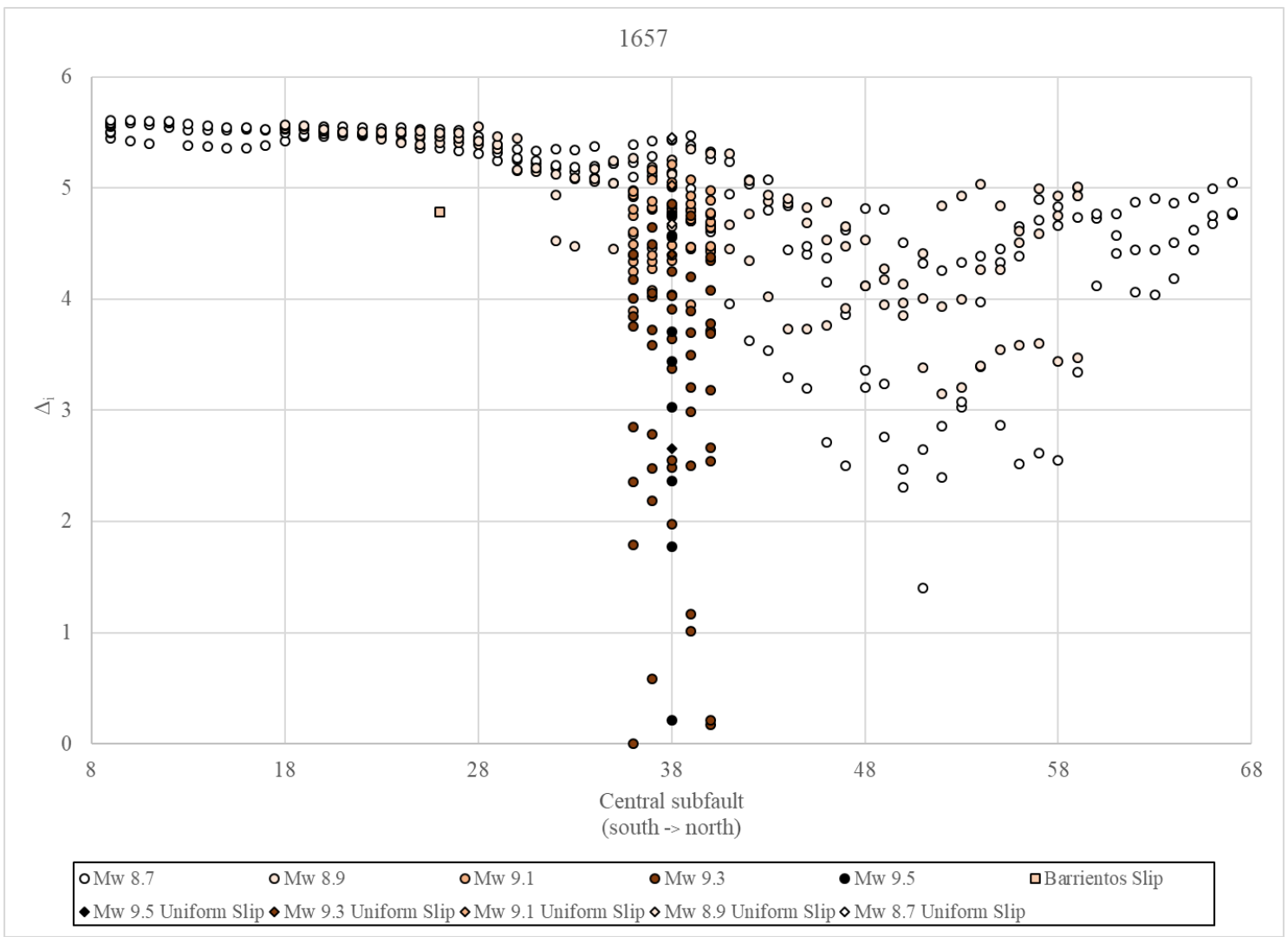

Figure 8: The $\Delta_{\mathrm{i}}$ versus central subfault of rupture for all tsunami simulations relative to the lowest AIC value calculated from observations of the 1657 historical tsunami. Earthquake magnitude positively correlates to darker colored data points. 

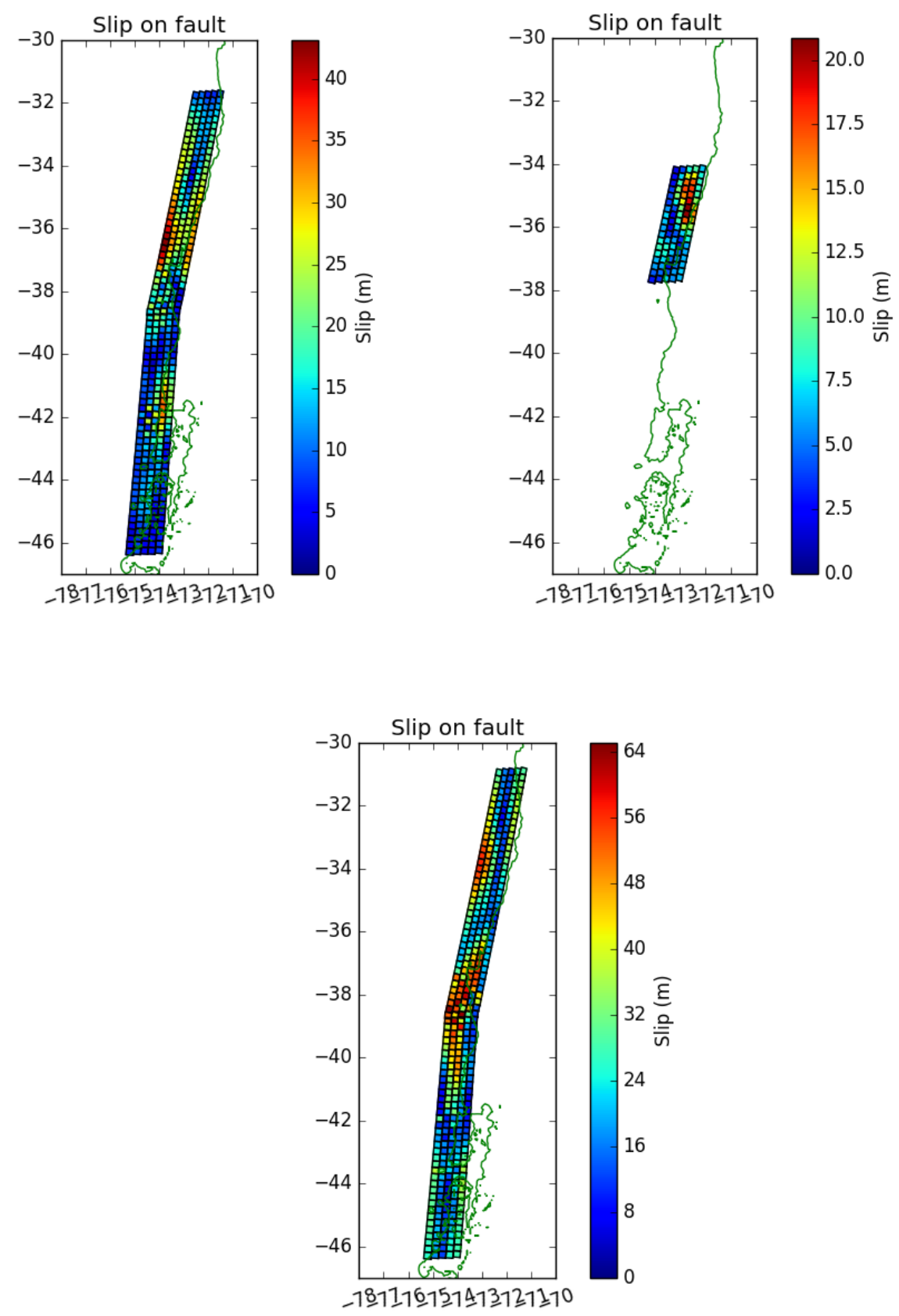

Figure 9: Potential rupture scenarios that were statistically significant, which yielded $\Delta_{\mathrm{i}}$ values that suggest a substantial fit based on the AIC equations for the 1657 event: left) model 36_93_3 and right) model 51_87_1, and bottom) model 38_95_1. 


\section{0 tsunami simulations}

The $1730 \mathrm{AIC}_{\mathrm{c}}$ analysis used seven tide gauges (Appendix D). Six tide gauges correlated to observations in the written record (Penco, Talcahuano, three around Valparaíso, and Valdivia), while the other one gauge correlated to an account within the geologic record at Campiche (Table 1). Based on the $\mathrm{AIC}_{\mathrm{c}}$ statistical analysis with these gauges, the $\Delta_{\mathrm{i}}$ of all 423 earthquake source models ranged from 0 to 58.60 and five yielded a $\Delta_{\mathrm{i}}$ value less than 7 (Appendix $\mathrm{E}_{4}$ ). These five earthquake source models had a RMSE value between $0.72 \mathrm{~m}$ and $1.18 \mathrm{~m}$, with four being a $\mathrm{M}_{\mathrm{w}} 9.3$ in size. Model 39_93_10 was the only "substantial fit" as no other solutions had a $\Delta_{\mathrm{i}}$ value less than 2.0 (Figure 10). The region of high slip concentration for this lone "substantially" significant model was located on the northern segment of the fault model at $\sim 34^{\circ} \mathrm{S}$ (Figure 11). Additionally, although not statistically significant, the $\mathrm{M}_{\mathrm{w}} 8.9$ and $\mathrm{M}_{\mathrm{w}} 8.7$ earthquake source models that ruptured the northern segment of the Chilean subduction zone had lower $\Delta_{\mathrm{i}}$ values than the earthquake source models that ruptured the southern segment (Appendix $\mathrm{E}_{4}$ ). 


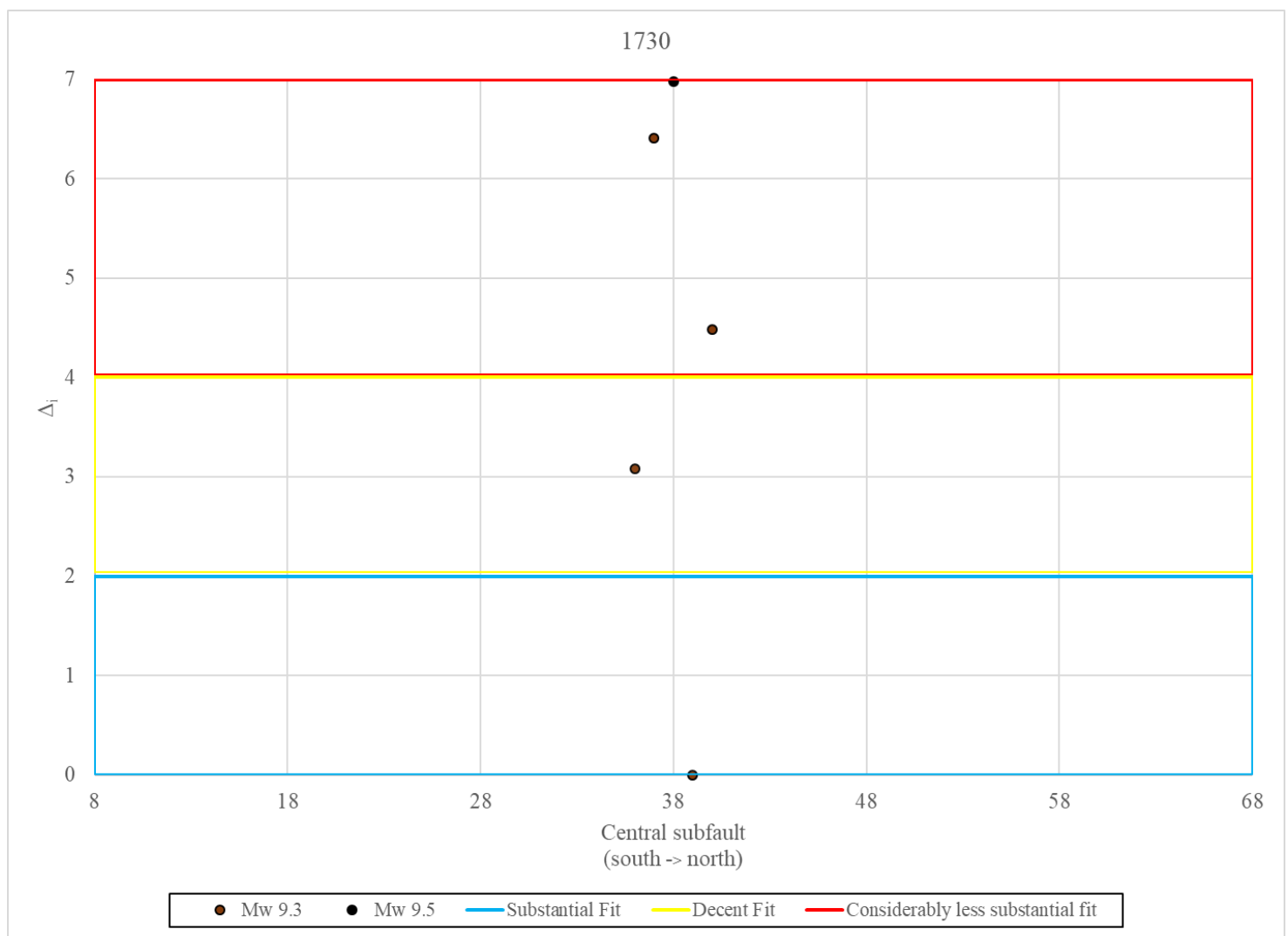

Figure 10: The five earthquake source models that yielded a $\Delta_{\mathrm{i}}<7.0$ when compared against the 1730 historical data. The tsunami simulations from earthquake source model 39_93_10 represents a statistically substantial fit based on the historical tsunami data available for the 1730 event. 


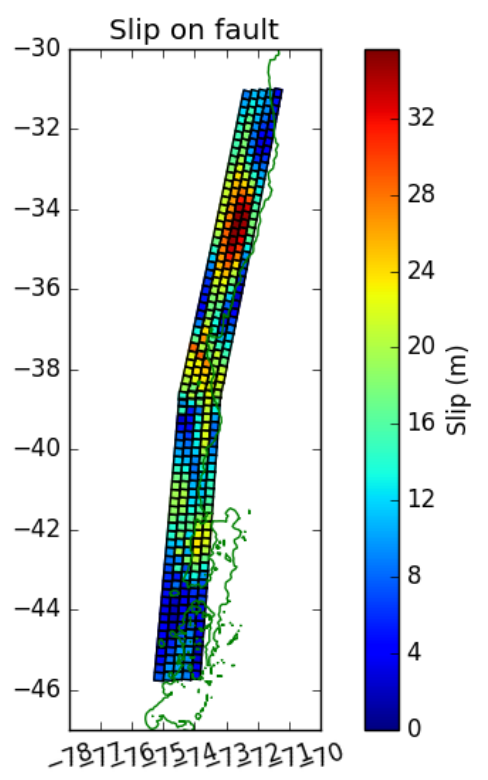

Figure 11: Potential rupture scenario that was a statistically significant, which yielded a $\Delta_{\mathrm{i}}$ value that suggests a substantial fit based on the AIC equations for the 1730 event: model 39_93_10.

\section{1 tsunami simulations}

The 1751 event used seven tide gauges in the $\mathrm{AIC}_{\mathrm{c}}$ analysis (Appendix D). Two tide gauges correlated to observations in the written record (Los Morros/Coliumu Bay), while five gauges correlated to accounts within the geologic record (three around Quidico and two around Tirúa; Table 1). Based on the $\mathrm{AIC}_{\mathrm{c}}$ statistical analysis with these gauges, the $\Delta_{\mathrm{i}}$ of all 423 earthquake source models ranged from 0 to 33.75, with 96 solutions yielding a $\Delta_{\mathrm{i}}$ value less than 7 (Appendix $\mathrm{E}_{5}$ ). Ten of these 96 earthquake models were "substantial fits" with $\Delta_{i}$ values less than 2.0 (Figure 12). These models, 57_87_3, 56_87_3, 58_87_3, 52_87_3, 52_89_2, 51_87_3, 49_87_3, 53_89_2, 40_93_5, and 
51_87_1, had RMSE values ranging from $2.24 \mathrm{~m}$ to $2.57 \mathrm{~m}$. The region of high slip concentration for the $\mathrm{M}_{\mathrm{w}} 8.7$ and $\mathrm{M}_{\mathrm{w}} 8.9$ earthquake source models was generally located at $\sim 35^{\circ} \mathrm{S}$ and $\sim 37^{\circ} \mathrm{S}$, respectively, while the statistically significant-fitting $\mathrm{M}_{\mathrm{w}} 9.3$ model, 40_93_5, suggests that the region of high slip was at $\sim 40{ }^{\circ} \mathrm{S}$ to $\sim 43^{\circ} \mathrm{S}$ (Figure $13)$.

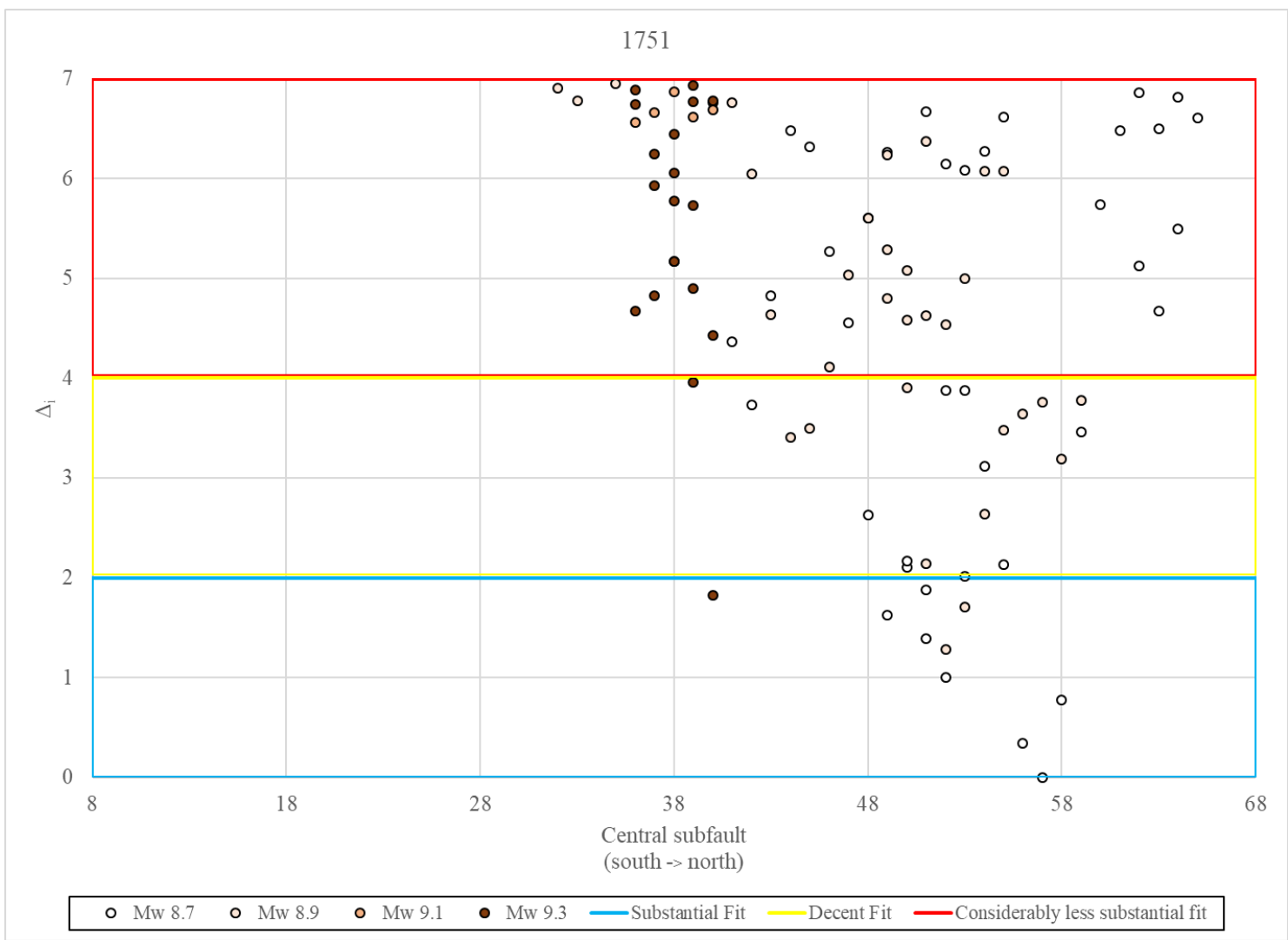

Figure 12: The 96 earthquake source models that yielded a $\Delta_{\mathrm{i}}<7.0$ when compared against the 1751 historical data. The tsunami simulations from earthquake source models 57_87_3, 56_87_3, 58_87_3, 52_87_3, 52_89_2, 51_87_3, 49_87_3, 53_89_2, 40_93_5, and 51_87_1 represent statistically substantial fits based on the historical tsunami data available for the 1751 event. 

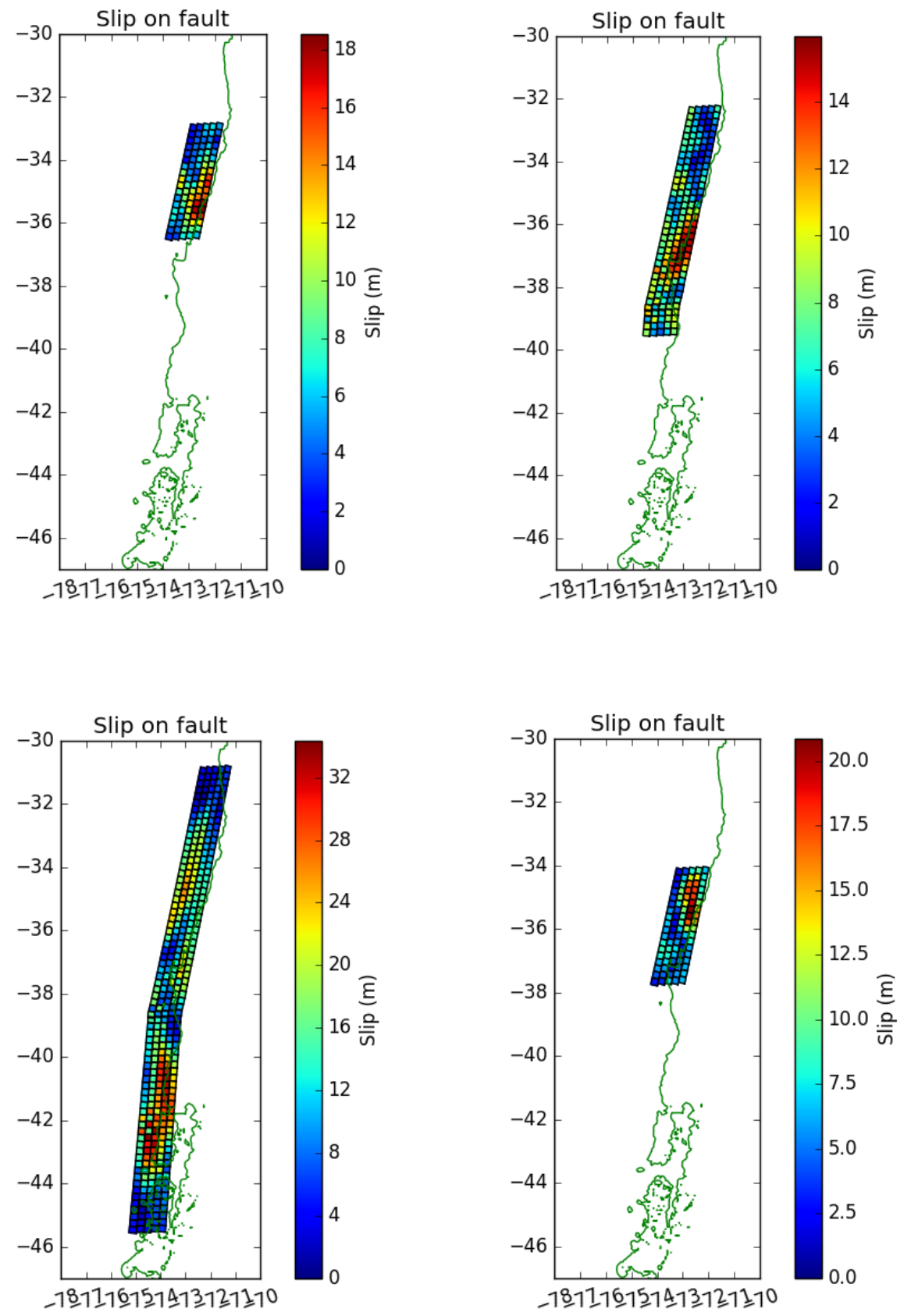

Figure 13: Potential rupture scenarios that were statistically significant, which yielded $\Delta_{\mathrm{i}}$ values that suggest a substantial fit based on the AIC equations for the 1751 event: top left) model 57_87_3, top right) 52_89_2, bottom left) model 40_93_5, bottom right 51_87_1. 


\section{2 tsunami simulations}

Three tide gauges used for the 1822 event analysis correlated to observations in the written record (Campiche, Valparaíso, and the Valdivia region; Appendix D; Table 1). The $\Delta_{\mathrm{i}}$ of all 423 earthquake source models within this statistical analysis ranged from 0 to 31.01 and 35 yielded a $\Delta_{\mathrm{i}}$ value less than 7 (Appendix $\mathrm{E}_{6}$ ). Four of these 35 earthquake models had a $\Delta_{\mathrm{i}}$ value less than 2.0, indicating "substantial fits" (Figure 14). These models, 59_87_2, 51_89_2, 52_89_2, and 56_89_2, had RMSE values that ranged between $0.72 \mathrm{~m}$ and $1.00 \mathrm{~m}$. The region of high slip concentration for these model was either shallow at $\sim 34^{\circ} \mathrm{S}$ to $\sim 35^{\circ} \mathrm{S}\left(\mathrm{M}_{\mathrm{w}} 8.7\right.$ source models $)$ or deep at $\sim 37^{\circ} \mathrm{S}\left(\mathrm{M}_{\mathrm{w}} 8.9\right.$ source models; Figure 15). 


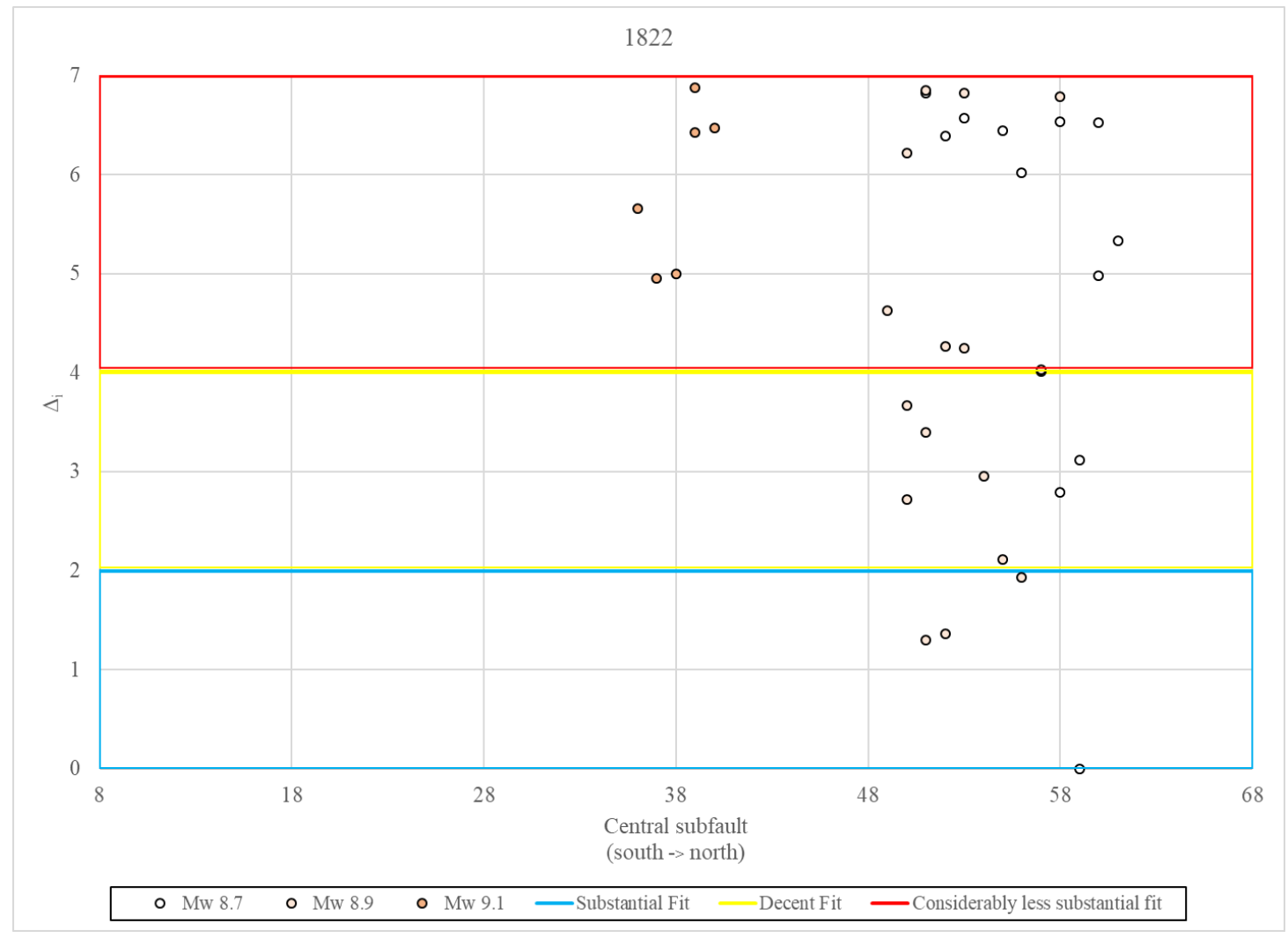

Figure 14: The 35 earthquake source models that yielded a $\Delta_{\mathrm{i}}<7.0$ when compared against the 1822 historical data. The tsunami simulations from earthquake source models 59_87_2, 51_89_2, 52_89_2, and 56_89_2 represent statistically substantial fits based on the historical tsunami data available for the 1822 event. 

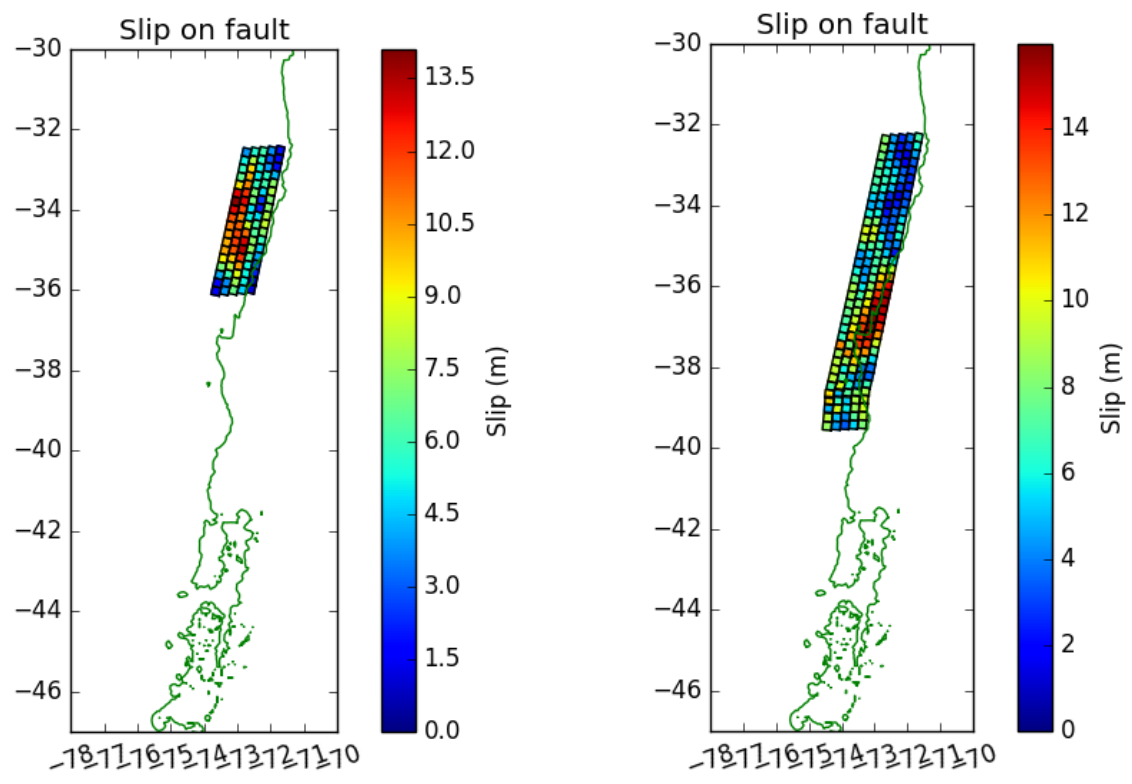

Figure 15: Potential rupture scenarios that were statistically significant, which yielded $\Delta_{\mathrm{i}}$ values that suggest a substantial fit based on the AIC equations for the 1822 event: left) model 59_87_2 and right) model 52_89_2.

\section{5 tsunami simulations}

Of the 17 tide gauges used for the 1835 event analysis (Appendix D), 14 gauges were from observations in the written record (Valparaíso, two north of Constitución, Tomé, south of Tomé, Talcahuano, Concepción Bay, San Vicente Bay, Penco, Coronel, Arauco Bay, Isla Mocha, Valdivia region, and northern Chiloe Island), and three from the geologic record (three around Quidico; Table 1). Based on the $\mathrm{AIC}_{\mathrm{c}}$ statistical analysis with these gauges, the $\Delta_{\mathrm{i}}$ of all 423 earthquake source models ranged from 0 to 66.54 and eight yielded a $\Delta_{\mathrm{i}}$ value less than 7 (Appendix $\mathrm{E}_{7}$ ). Two of these eight earthquake models were "substantial fits" with $\Delta_{i}$ values less than 2.0 (Figure 17). These models, 46_87_1 
and 45_87_1, had RMSE values of $3.59 \mathrm{~m}$ and $3.77 \mathrm{~m}$. The area of high slip concentration for these $\mathrm{M}_{\mathrm{w}} 8.7$ source models were located on the northern segment of the fault model at $\sim 36.5^{\circ} \mathrm{S}$ (Figure 16). However, the $\mathrm{M}_{\mathrm{w}} 9.3$ and $\mathrm{M}_{\mathrm{w}} 9.5$ source models with $\Delta_{\mathrm{i}}$ values less than 7 (40_93_9, 39_93_9, and 38_95_8) yielded slightly lower RMSE values ( 3.52 to $3.57 \mathrm{~m}$ ) than the $\mathrm{M}_{\mathrm{w}} 8.7$ source models. The main concentrations of slip for the larger source models are different from the smaller $\mathrm{M}_{\mathrm{w}} 8.7$ source models: the high slip for the two $M_{w} 9.3$ source models occurred at $~ 39^{\circ} S$, and the $M_{w} 9.5$ source model had high slip between $\sim 40^{\circ} \mathrm{S}$ to $\sim 44^{\circ} \mathrm{S}$ in the deeper portion of the fault model (Figure 17). 


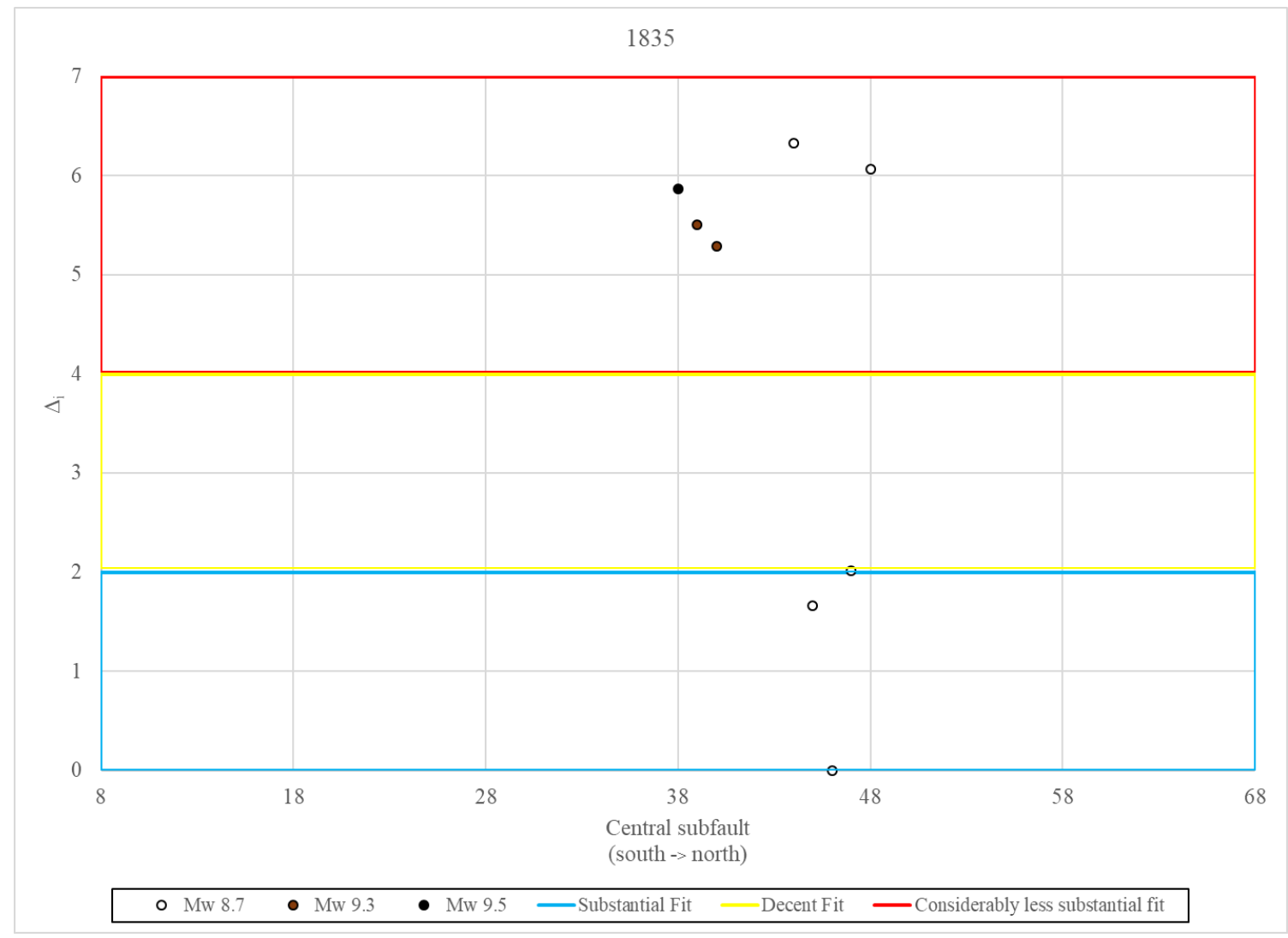

Figure 16: The eight earthquake source models that yielded a $\Delta_{\mathrm{i}}<7.0$ when compared against the 1835 historical data. The tsunami simulations from earthquake source models 46_87_1 and 45_87_1 represent statistically substantial fits based on the historical tsunami data available for the 1835 event. 

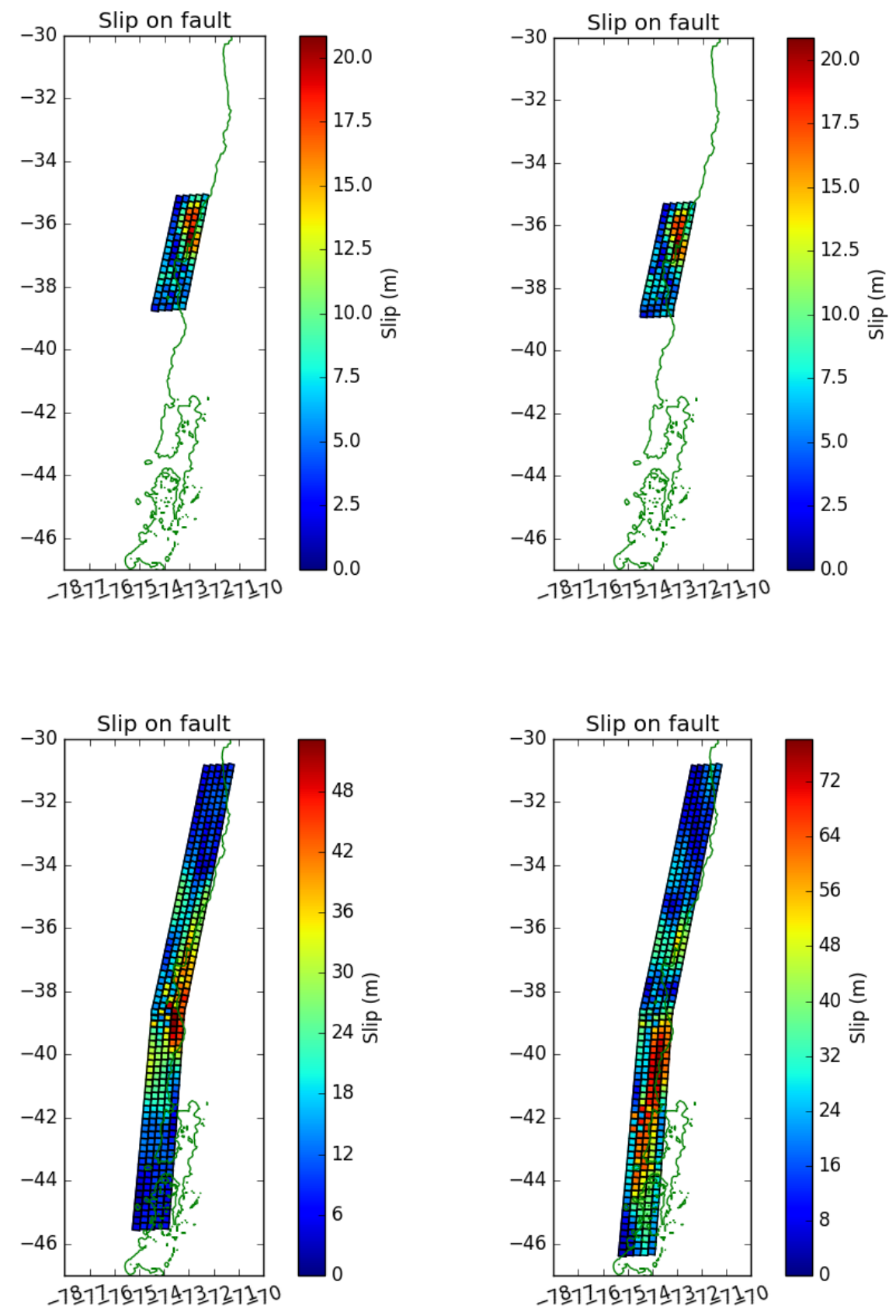

Figure 17: Potential rupture scenario that was statistically significant, which yielded $\Delta_{\mathrm{i}}$ values that suggest a substantial fit based on the AIC equations for the 1835 event: top left) model 46_87_1, top right right) model 45_87_1, bottom left) 40_93_9, and bottom right) 38_95_8. 


\section{7 tsunami simulations}

Of the eight tide gauges used for the 1837 event analysis (Appendix D), six tide gauges correlated to observations in the written record (Valparaíso, Concepción Bay, the Valdivia region, Maullín, and north Chiloe Island), while the two gauges correlated to accounts within the geologic record (Cocotue and Lake Huelde; Table 1). Based on the $\mathrm{AIC}_{\mathrm{c}}$ statistical analysis with these gauges, the $\Delta_{\mathrm{i}}$ of all 423 earthquake source models ranged from 0 to 64.88 (Appendix $\mathrm{E}_{8}$ ) and 55 yielded a $\Delta_{\mathrm{i}}$ value less than 7 (Figure 18). All 56 earthquake source models with a $\Delta_{\mathrm{i}}$ less than 7 had a RMSE value between $0.84 \mathrm{~m}$ and $1.29 \mathrm{~m}$. The position of these earthquake source models varied significantly along strike, with a cluster of models with high slip on the southern segment of the fault model (e.g. 11_87_3) and a cluster of models with high slip on the northern segment (e.g. 52_87_2 and 50_87_3; Figure 19). Fifteen of these 56 earthquake models yielded a $\Delta_{\mathrm{i}}$ value less than 2.0, indicating "substantial fits" (Figure 18). These "substantial fits" corresponded to having high slip on the northern segment of the fault model, as opposed to the southern segment. 


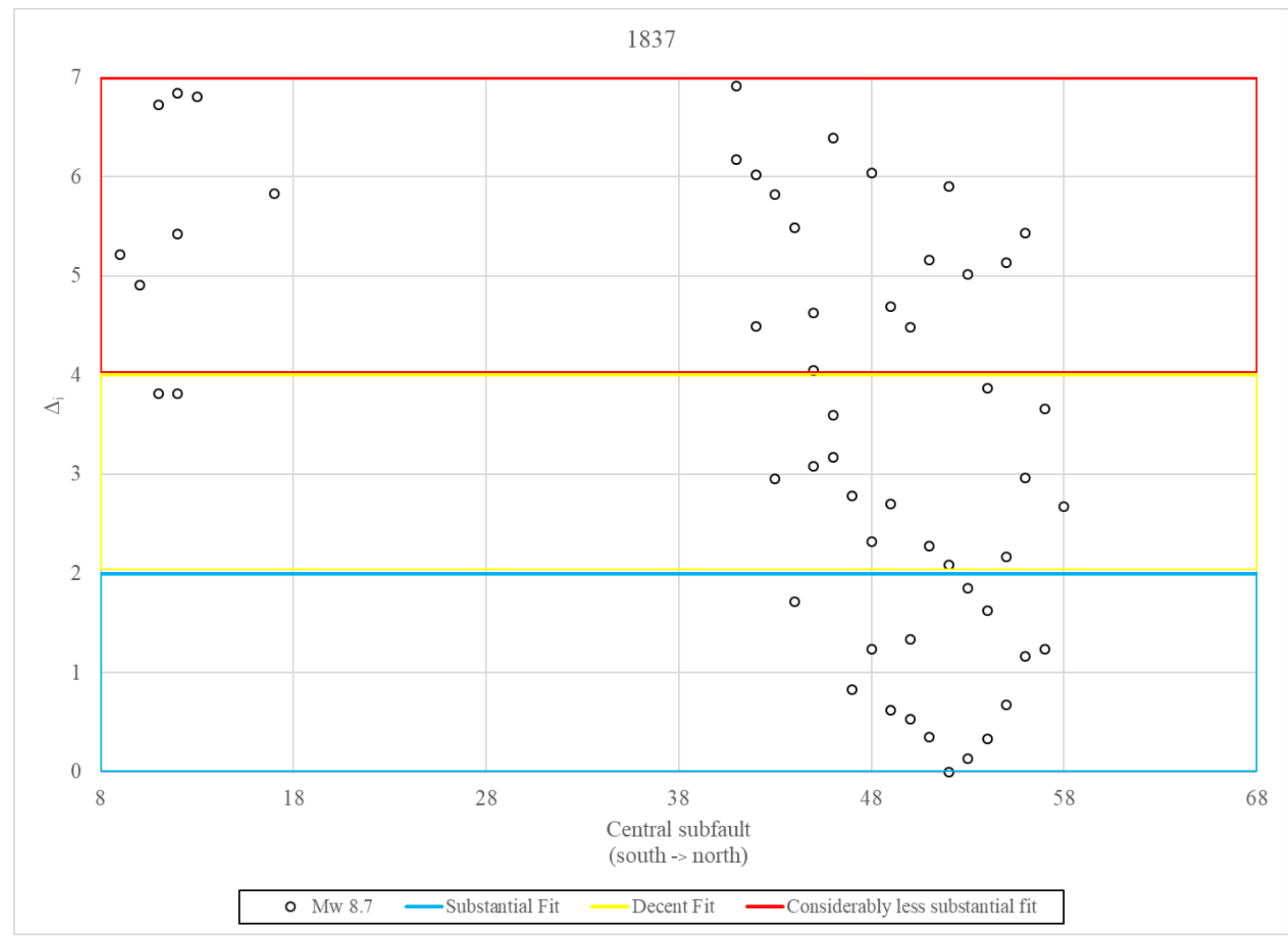

Figure 18: The 56 earthquake source models that yielded a $\Delta_{\mathrm{i}}<7.0$ when compared against the 1837 historical data. There were two spatial clusters of earthquake point source models in the south and north. These clusters may be a result from tsunami simulations over fitting two regions of spatially adjacent wave height data in the south and north that was data available for the 1837 event. 

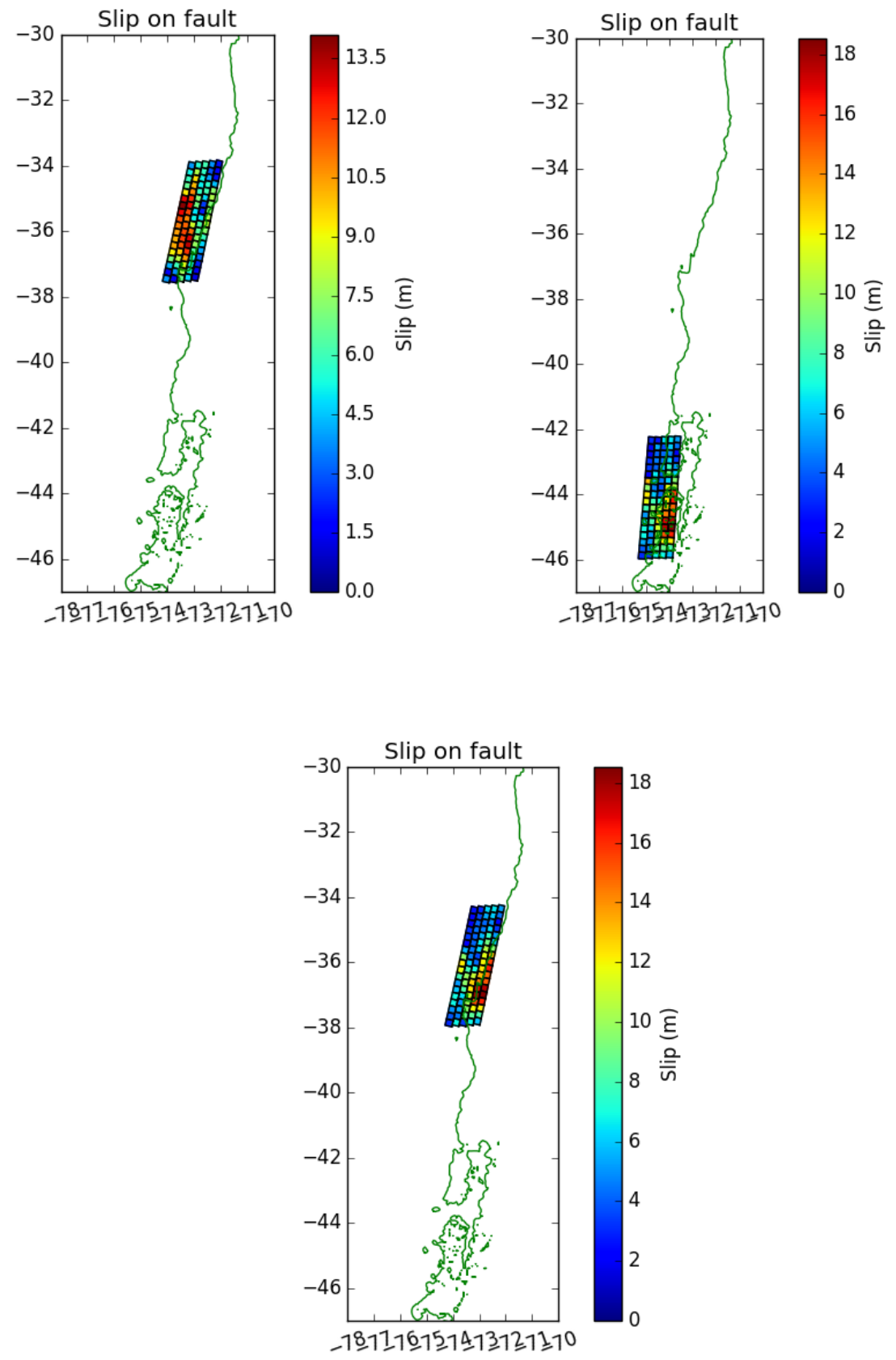

Figure 19: Potential rupture scenarios that were statistically significant, which yielded $\Delta_{\mathrm{i}}$ values that suggest a substantial fit based on the AIC equations for the 1837 event: left) model 52_87_2, right) model 11_87_3, and bottom) 50_87_3. 


\section{1 tsunami simulations}

There was only one observation for 1871 event (a written record in Valparaíso), therefore only one tide gauge was used for the $\mathrm{AIC}_{\mathrm{c}}$ statistical analysis (Appendix D; Table 1). The $\Delta_{\mathrm{i}}$ of all 423 earthquake source models at this one tide gauge ranged from 0 to 16.08 with 29 yielding a $\Delta_{\mathrm{i}}$ value less than 7 (Appendix $\mathrm{E}_{9}$ ). Five of these 29 earthquake models had a $\Delta_{\mathrm{i}}$ value less than 2.0, indicating "substantial fits" (Figure 20). These models, 52_87_2, 53_87_2, 56_87_3, 54_87_3, and 51_87_3, had an RMSE value between $0.02 \mathrm{~m}$ and $0.07 \mathrm{~m}$. The region of high slip for all of these models was either located on deeper or shallower portion of the northern segment of the fault model at $35.5^{\circ} \mathrm{S}$ (Figure 21). 


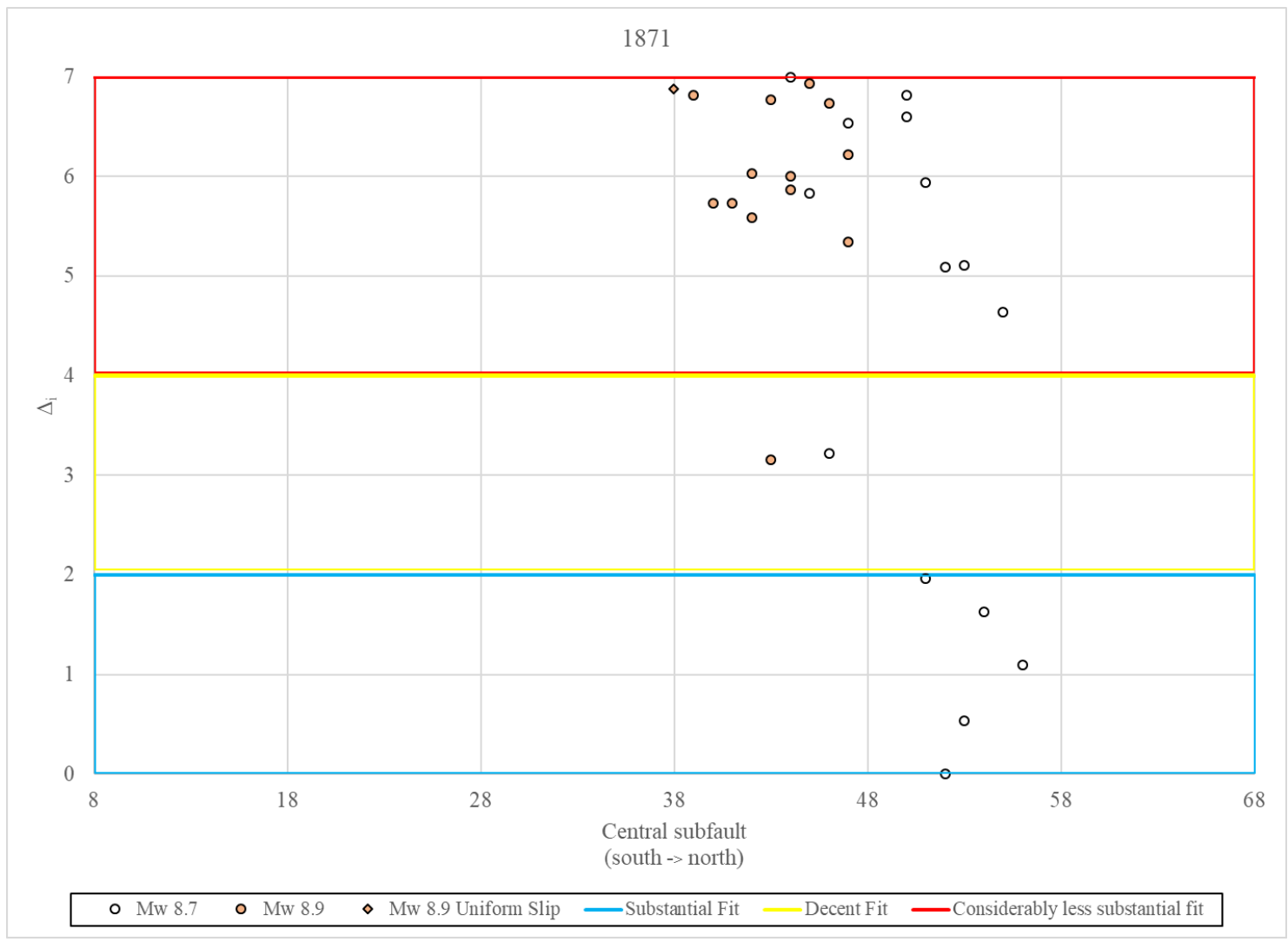

Figure 20: The 29 earthquake source models that yielded a $\Delta_{\mathrm{i}}<7.0$ when compared against the 1871 historical data. The tsunami simulations from earthquake source models 52_87_2, 53_87_2, 56_87_3, 54_87_3, and 51_87_3 represent statistically substantial fits based on the historical tsunami data available for the 1871 event. 

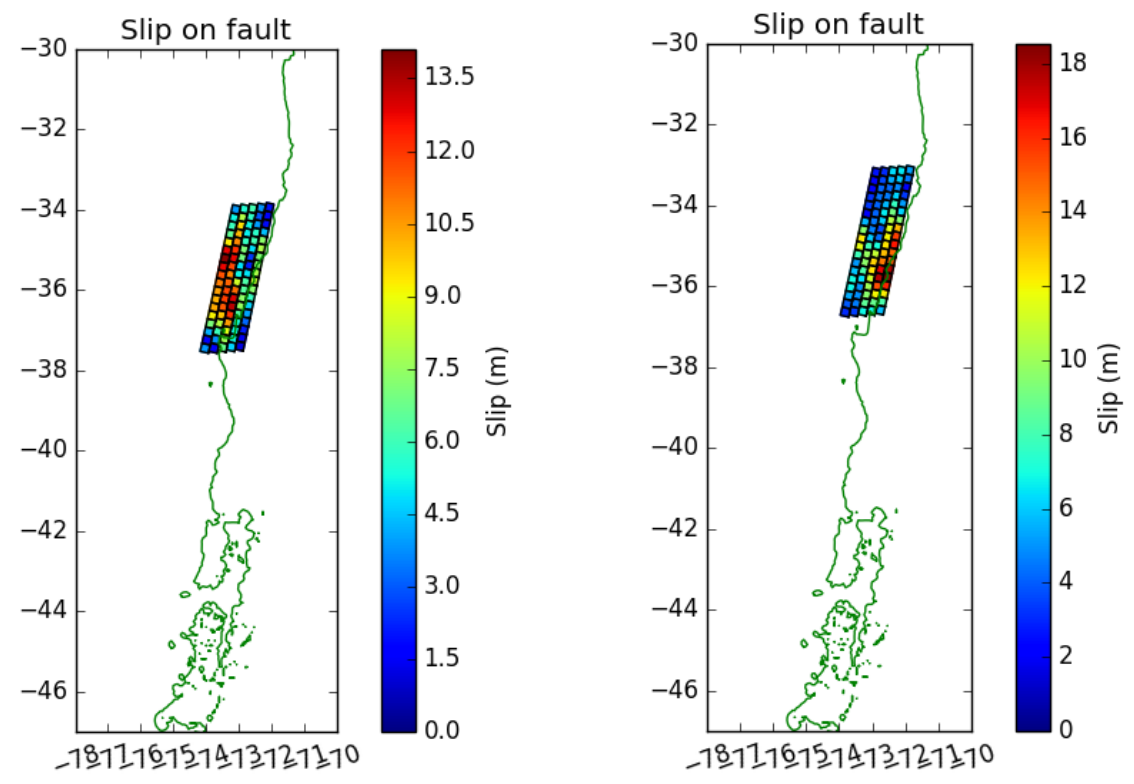

Figure 21: Potential rupture scenarios that were statistically significant, which yielded $\Delta_{\mathrm{i}}$ values that suggest a substantial fit based on the AIC equations for the 1871 event: left) model 52_87_2 and right) model 56_87_3.

\section{1b tsunami simulations}

The $1871 \mathrm{~b}$ event was associated with one tsunami observation (at Puerto Montt), and therefore only tide gauge was used for the $\mathrm{AIC}_{\mathrm{c}}$ statistical analysis (Appendix D; Table 1). The $\Delta_{\mathrm{i}}$ of all 423 earthquake source models from the gauge at Puerto Montt ranged from 0 to 12.31 and 42 yielded a $\Delta_{\mathrm{i}}$ value less than 7 (Appendix $\mathrm{E}_{10}$ ). Of these 42 earthquake models, three had a $\Delta_{\mathrm{i}}$ value less than 2.0, indicating "substantial fits" (Figure 22). These models, 37_93_9, 36_91_3, and 40_93_10, had a RMSE value between 0.02 $\mathrm{m}$ and $0.03 \mathrm{~m}$. Additionally, some $\mathrm{M}_{\mathrm{w}} 8.7$ earthquakes that ruptured on the southern segment should be considered as potential fits as well (e.g. model 15_87_3 with $\Delta_{\mathrm{i}}$ value 
of 2.88; see Discussion chapter regarding localized tsunami accounts with only one observation). The region of maximum of slip for these earthquake source models were either located at $\sim 40^{\circ} \mathrm{S}$ or $\sim 34^{\circ} \mathrm{S}$ for the $\mathrm{M}_{\mathrm{w}} 9.3$ models, $\sim 40^{\circ} \mathrm{S}$ and $\sim 36^{\circ} \mathrm{S}$ for the $\mathrm{M}_{\mathrm{w}}$ 9.1 model, and at $\sim 44^{\circ} \mathrm{S}$ for the smaller $\mathrm{M}_{\mathrm{w}} 8.7$ models (Figure 23).

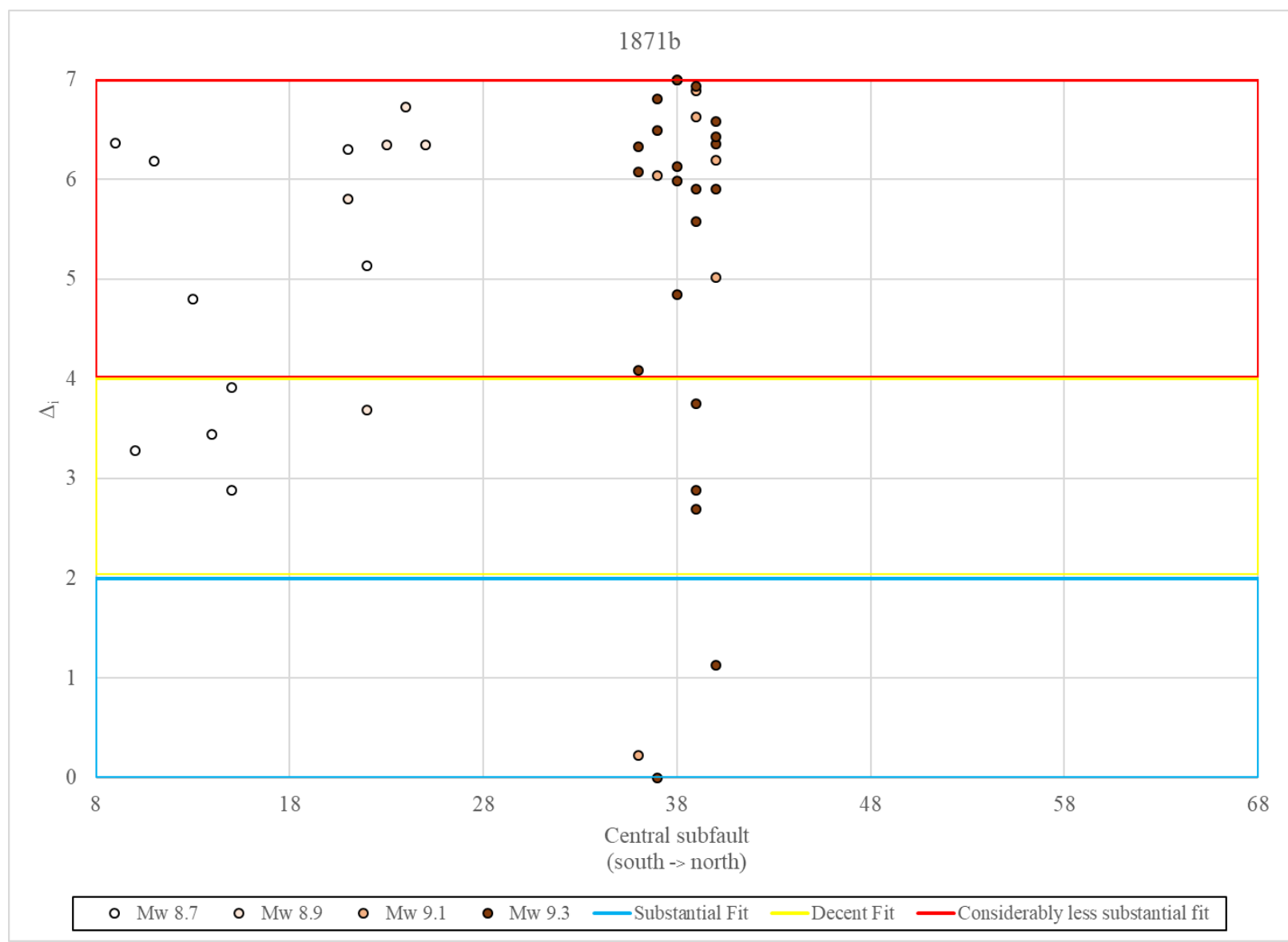

Figure 22: The 42 earthquake source models that yielded a $\Delta_{\mathrm{i}}<7.0$ when compared against the $1871 \mathrm{~b}$ historical data. The tsunami simulations from earthquake source models 37_93_9, 36_91_3, and 40_93_10 represent statistically substantial fits based on the historical tsunami data available for the $1871 \mathrm{~b}$ event. 

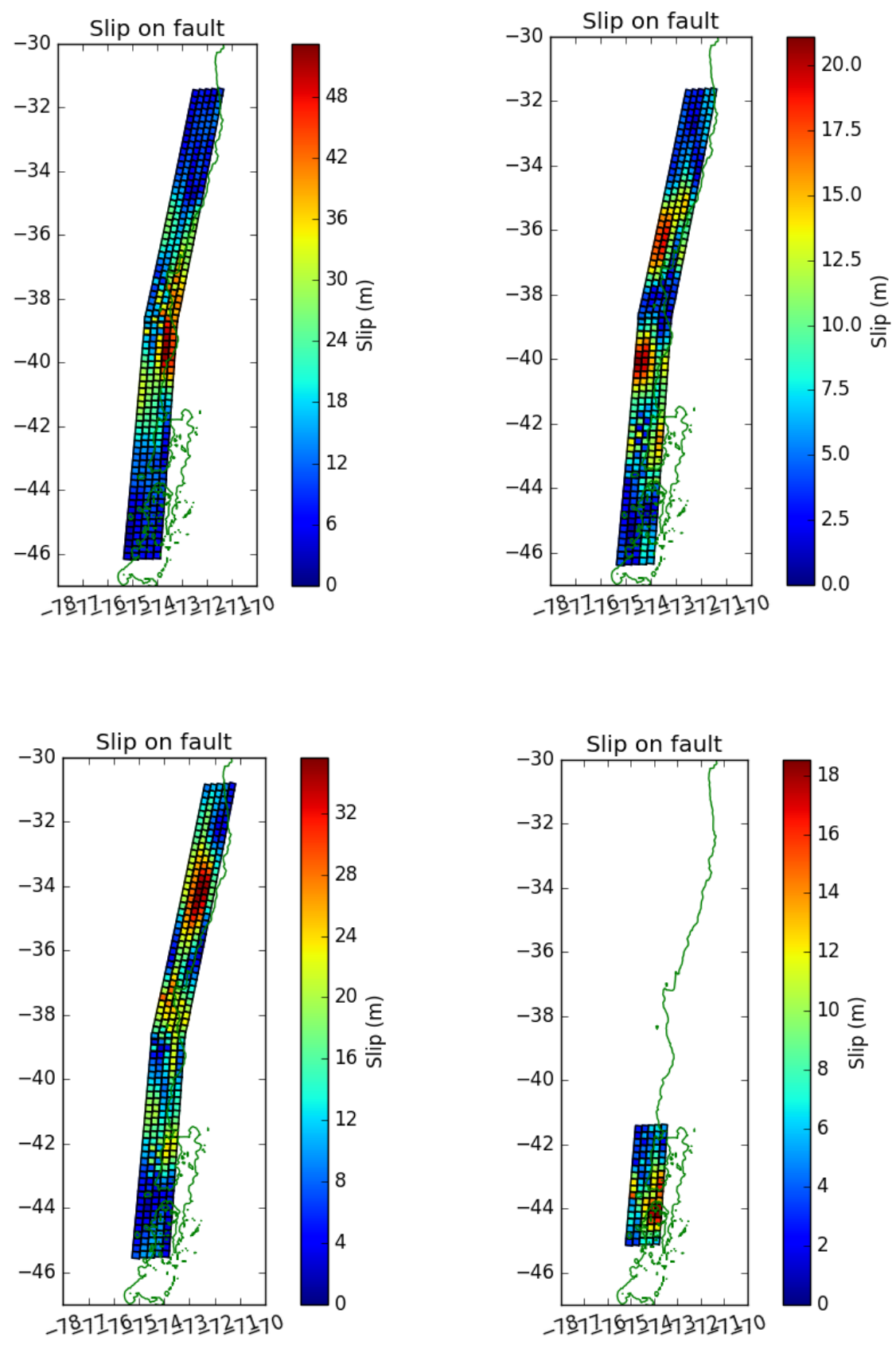

Figure 23: Potential rupture scenarios that were statistically significant for the $1871 \mathrm{~b}$ event: top left) model 37_93_9, top right) 36_91_3, bottom left) model 40_93_10, and bottom right) model 15_87_3. 


\section{8 ts unami simulations}

The $1898 \mathrm{AIC}_{\mathrm{c}}$ analysis used only one tide gauge to account for the individual observation in the written record at Concepción Bay (Appendix D; Table 1). The $\Delta_{\mathrm{i}}$ of all 423 earthquake source models ranged from 0 to 18.48 and 15 yielded a $\Delta_{\mathrm{i}}$ value less than 7. All 15 of these statistically significant solutions ruptured on the southern segment of the Chilean subduction zone (Appendix $E_{11}$ ). However, none of these 15 earthquake models were within a $\Delta_{\mathrm{i}}$ value of 2.0 from the best model, 17_87_2 (Figure 24). Model 17_87_2 had a RMSE of $0.01 \mathrm{~m}$ and a region of high slip located in the shallow part of the fault model between $\sim 42.5^{\circ} \mathrm{S}$ and $\sim 43.5^{\circ} \mathrm{S}$ (Figure 25). 


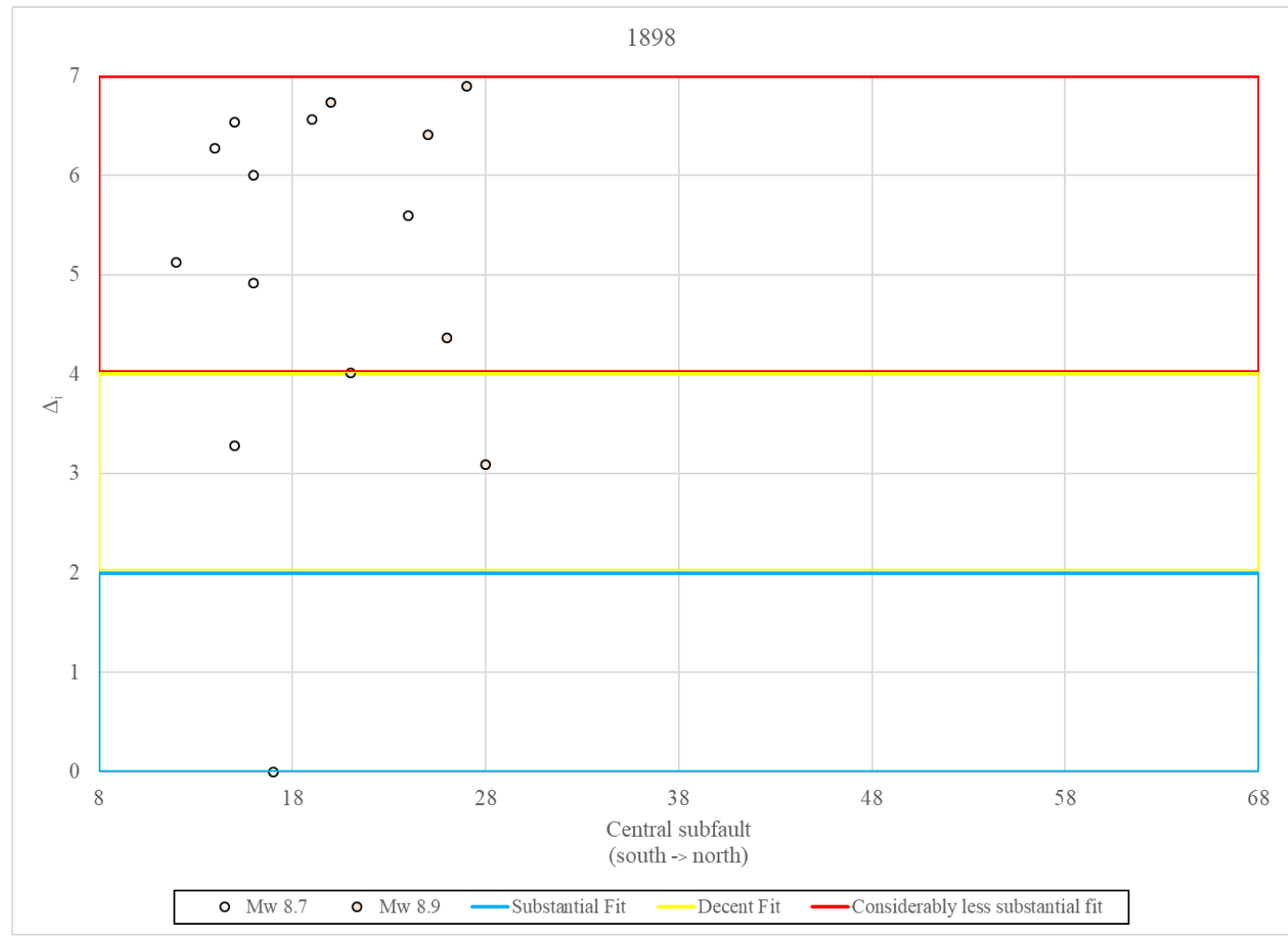

Figure 24: The 15 earthquake source models that yielded a $\Delta_{\mathrm{i}}<7.0$ when compared against the 1898 historical data. The tsunami simulation from earthquake source models 17_87_2 represents a statistically substantial fits based on the historical tsunami data available for the 1898 event. 


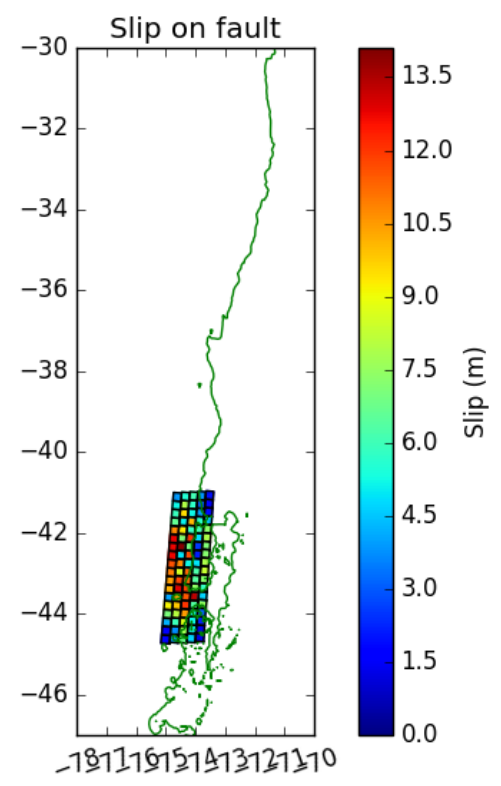

Figure 25: Potential rupture scenario that was statistically significant, which yielded a $\Delta_{\mathrm{i}}$ value that suggests a substantial fit based on the AIC equations for the 1898 event: model 17_87_2.

\section{6 tsunami simulations}

Nine tide gauges were used for the $1906 \mathrm{AIC}_{\mathrm{c}}$ analysis to account for all observations within the written record (Los Vilos, Valparaíso, three north of Constitución, Tomé, south of Tomé, Talcahuano, Penco, and Coronel; Appendix D; Table 1). The $\Delta_{\mathrm{i}}$ of all 423 earthquake source models in this analysis ranged from 0 to 59.37 and 175 yielded a $\Delta_{i}$ value less than 7 (Appendix $E_{12}$ ). 68 of these 175 earthquake models, had a $\Delta_{\mathrm{i}}$ value less than 2.0, indicating "substantial fits" (Figure 26). These 68 earthquake source models have a small range in RMSE with values from $1.45 \mathrm{~m}$ to 1.62 m. The majority of these top 68 models were $M_{w} 8.7$ in size and ruptured the south- 
central area of the Chilean subduction zone. The region of high slip for these models was located near the Mocha fracture zone at 39 $\mathrm{S}$ (Figure 27).

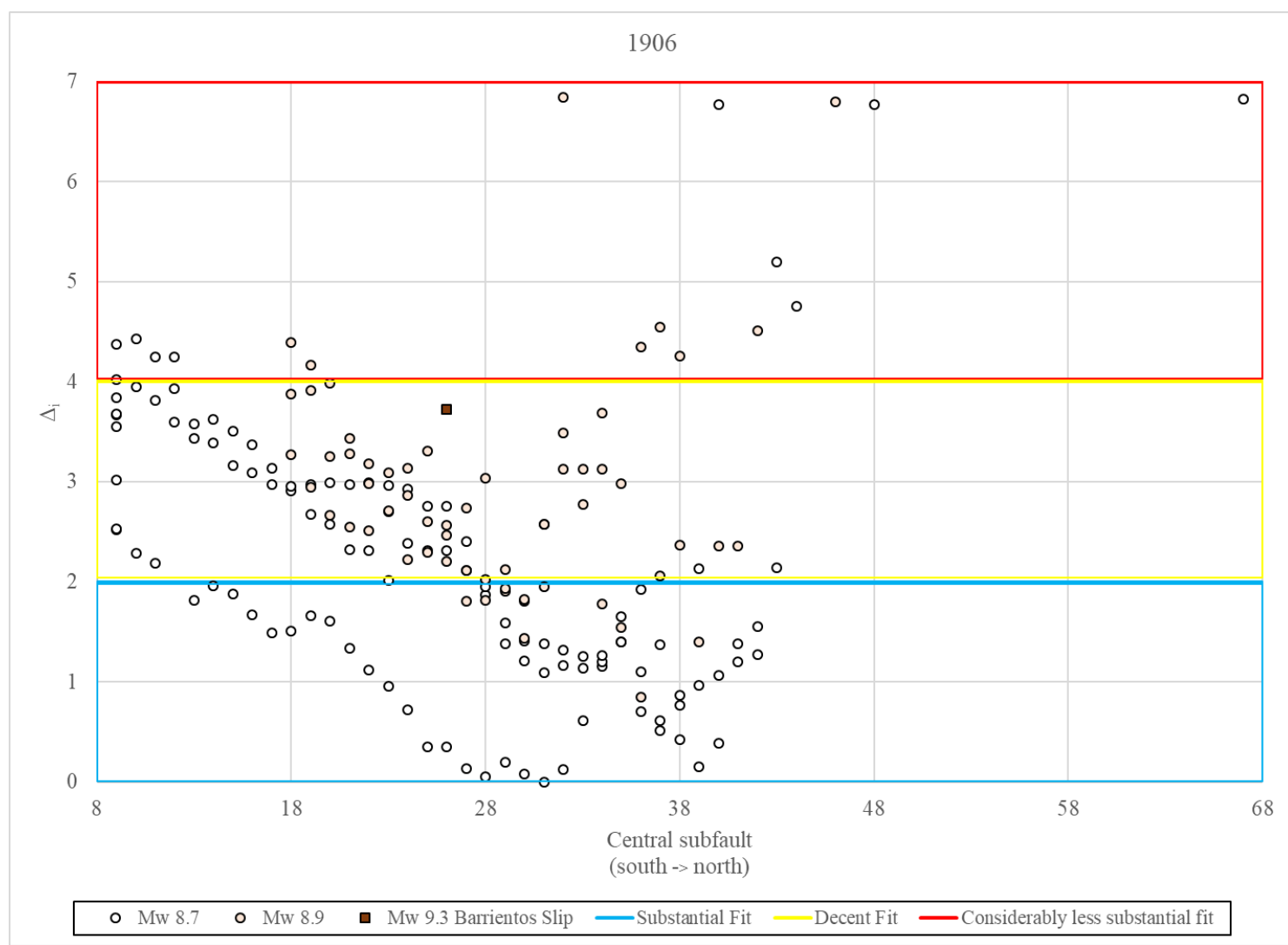

Figure 26: The 175 earthquake source models that yielded a $\Delta_{\mathrm{i}}<7.0$ when compared against the 1906 historical data. The statistically substantial fit tsunami simulations were generally derived from $\mathrm{M}_{\mathrm{w}} 8.7$ earthquake source models that ruptured the south-central segment of the subduction zone. 

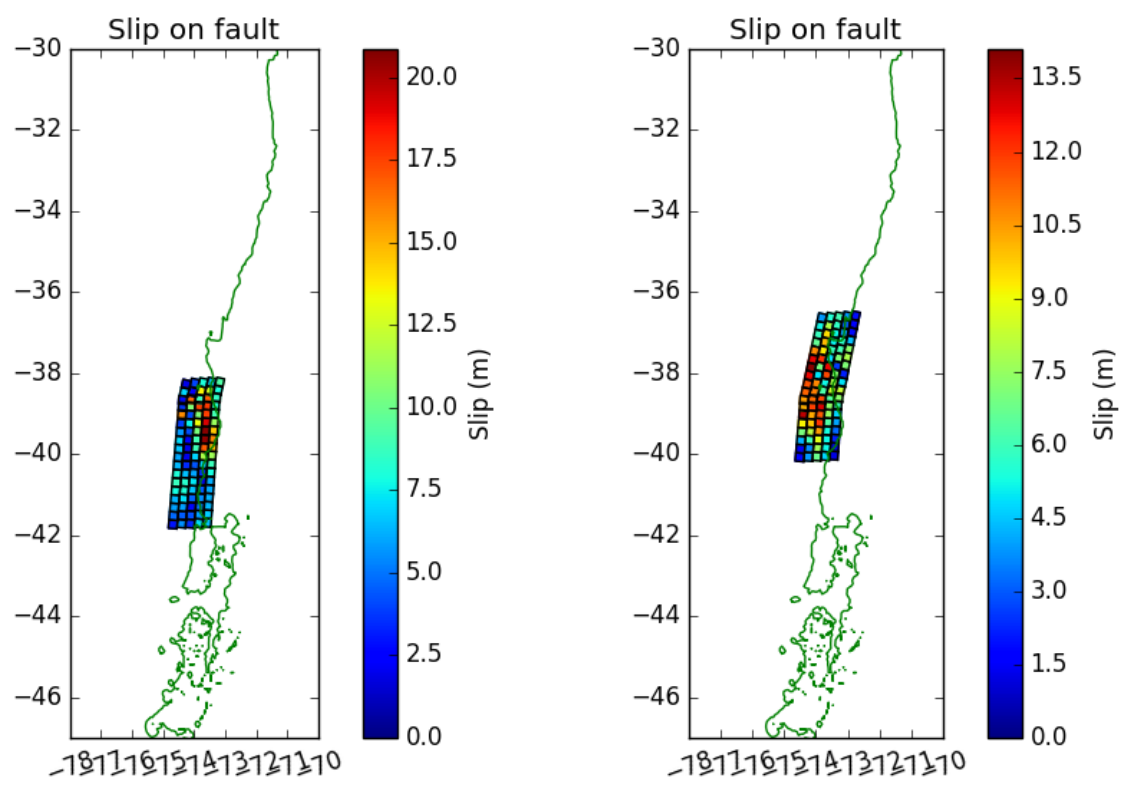

Figure 27: Potential rupture scenarios that were statistically significant, which yielded a $\Delta_{\mathrm{i}}$ value that suggests a substantial fit based on the AIC equations for the 1906 event: left) model 31_87_1 and right) model 39_87_2.

\section{0 tsunami simulations}

The $1920 \mathrm{AIC}_{\mathrm{c}}$ analysis used four tide gauges that corresponded to four observations within the written record (one at Talcahuano and three from the Arauco Province; Appendix D; Table 1). Based on the $\mathrm{AIC}_{\mathrm{c}}$ statistical analysis with these gauges, the $\Delta_{\mathrm{i}}$ of all 423 earthquake source models ranged from 0 to 57.05 and 17 yielded a $\Delta_{\mathrm{i}}$ value less than 7 (Appendix $\mathrm{E}_{13}$ ). Three of these 17 earthquake models, had a $\Delta_{\mathrm{i}}$ value less than 2.0, indicating "substantial fits" (Figure 28). These models, 24_87_1, 29_87_2, and 23_87_1, had RMSE values that ranged from $0.29 \mathrm{~m}$ to $0.36 \mathrm{~m}$. The region of high 
slip for these models was located on the southern segment of the fault model between $40^{\circ} \mathrm{S}$ and $\sim 41^{\circ} \mathrm{S}$ (Figure 29 ).

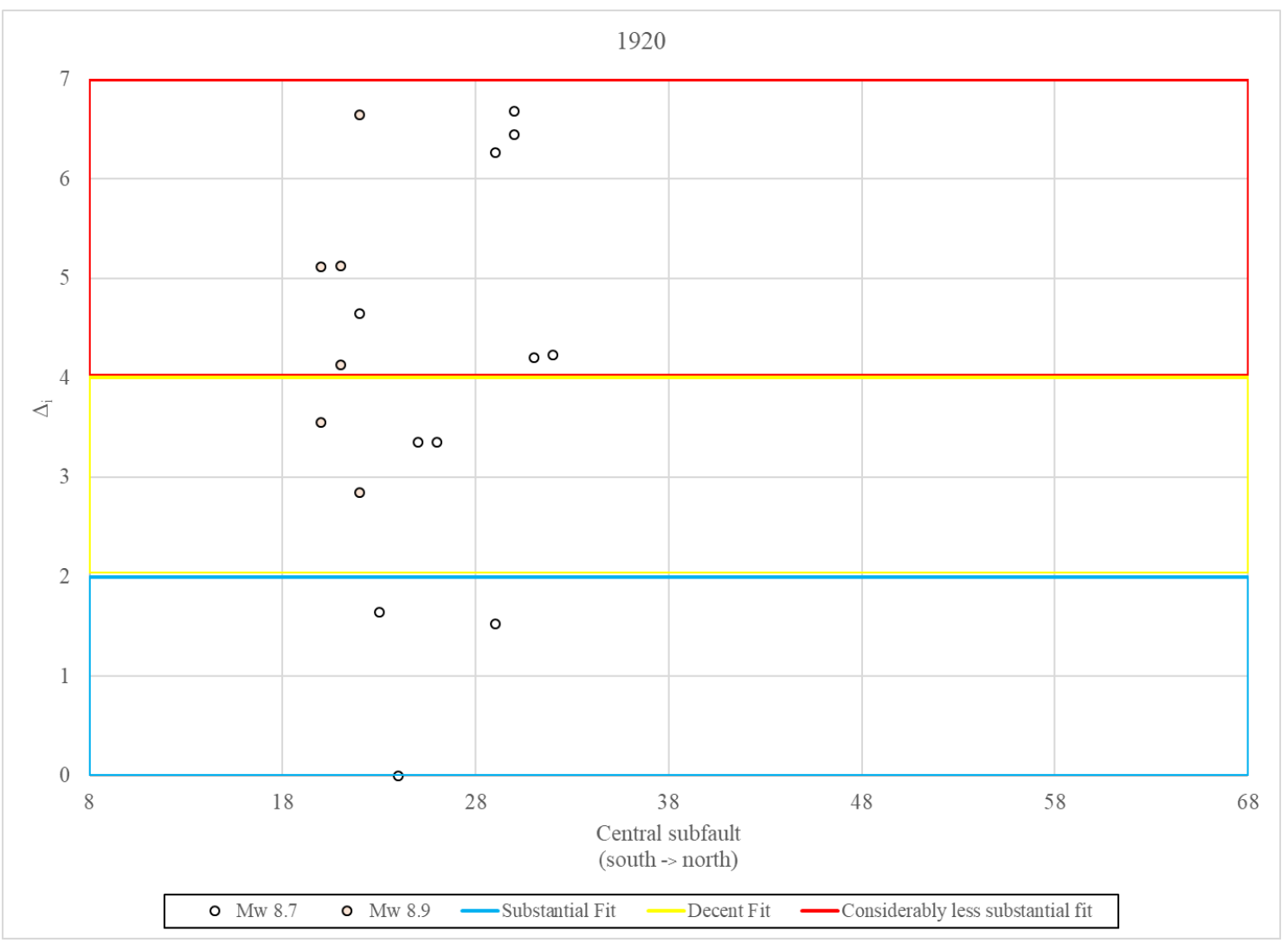

Figure 28: The 17 earthquake source models that yielded a $\Delta_{\mathrm{i}}<7.0$ when compared against the 1920 historical data. The tsunami simulations from earthquake source models 24_87_1, 29_87_2, and 23_87_1 represent statistically substantial fits based on the historical tsunami data available for the 1920 event. 

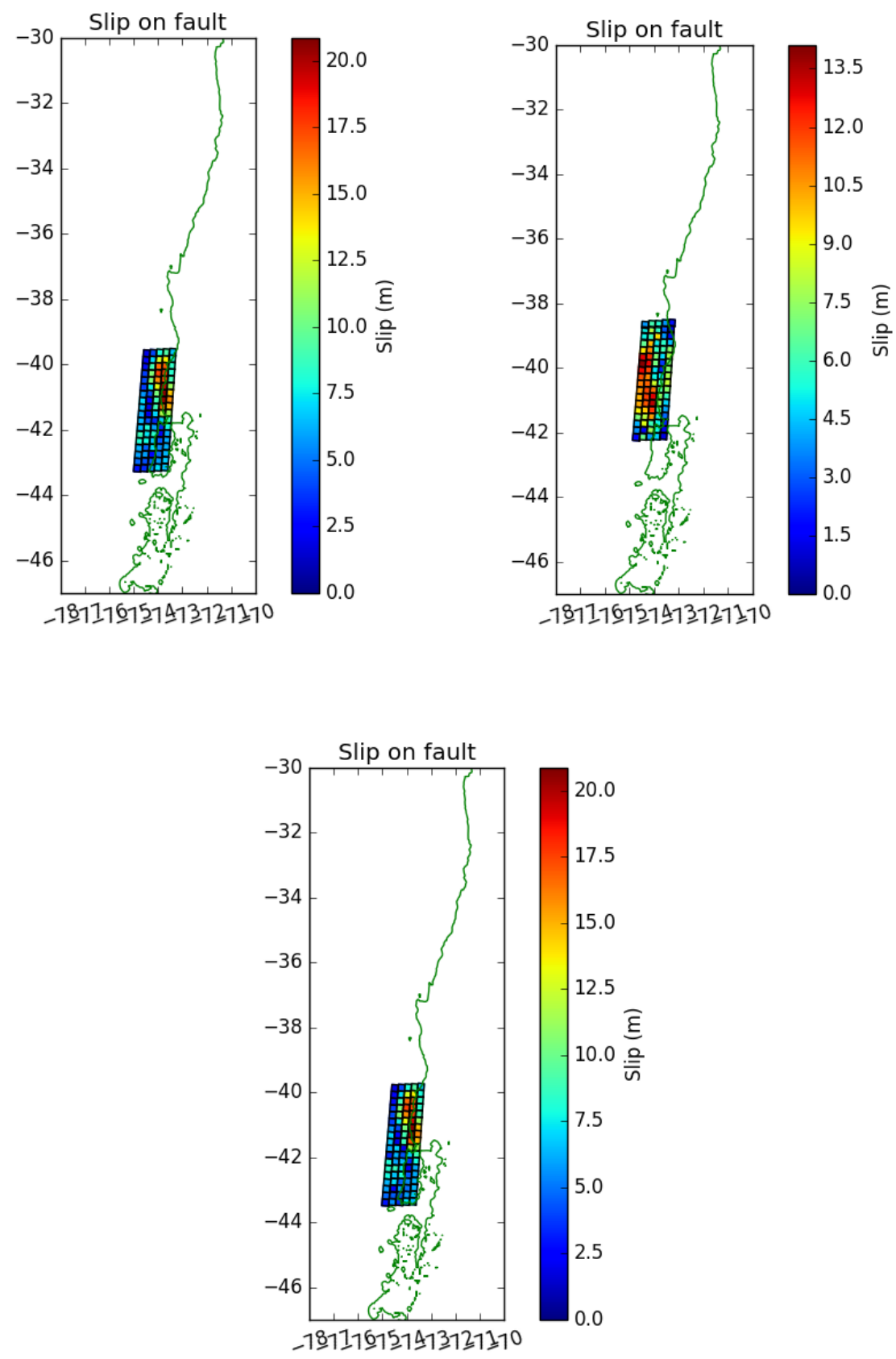

Figure 29: Potential rupture scenarios that were statistically significant, which yielded a $\Delta_{\mathrm{i}}$ value that suggests a substantial fit based on the AIC equations for the 1920 event: left) model 24_87_1, right) model 29_87_2, and bottom) model 23_87_1. 


\section{7 tsunami simulations}

The $1927 \mathrm{AIC}_{\mathrm{c}}$ analysis used two tide gauges corresponding to observations in the written record at Puerto Aysen and Puerto Cisnes (Appendix D; Table 1). Based on the $\mathrm{AIC}_{\mathrm{c}}$ statistical analysis with these gauges, the $\Delta_{\mathrm{i}}$ of all 423 earthquake source models all appear to have the same result (Figure 30; Appendix $E_{14}$ ). By definition of the AIC equations, one model must receive a $\Delta_{\mathrm{i}}$ of 0 . However, all models had an RMSE value of $5.95 \mathrm{~m}$, which confirms that water did not reach the tide gauges in any models. Puerto Asyen and Puerto Cisnes are located in southern Chile within fjords $\sim 140 \mathrm{~km}$ from the open ocean. 


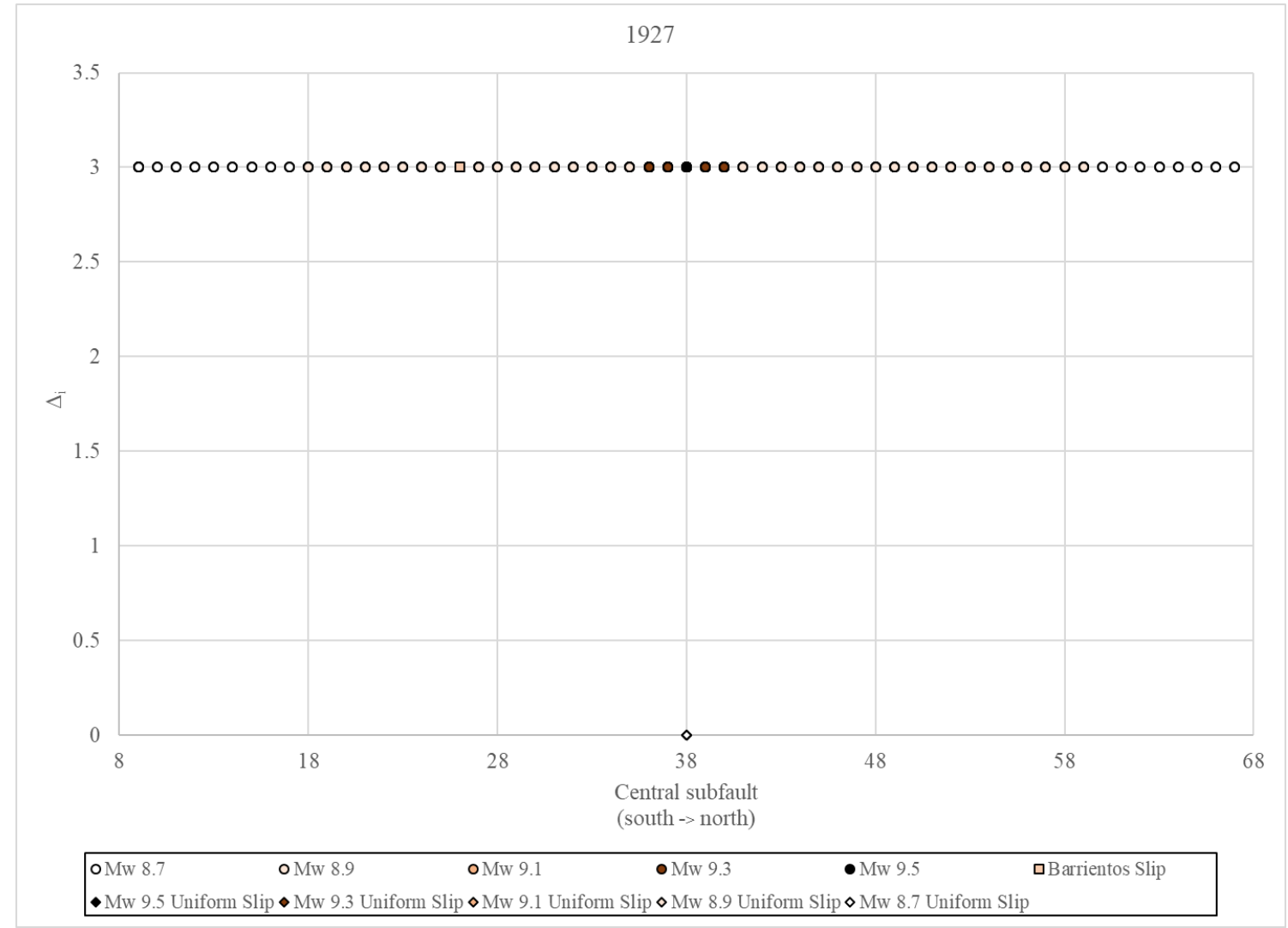

Figure 30: The $\Delta_{\mathrm{i}}$ versus central subfault of rupture for all tsunami simulations relative to the lowest AIC value calculated from observations of the 1927 historical tsunami. Earthquake magnitude positively correlates to darker colored data points.

\section{8 tsunami simulations}

The $1928 \mathrm{AIC}_{\mathrm{c}}$ analysis used two tide gauges that corresponded to observations in the written record just north of Constitución (Appendix D; Table 1). The $\Delta_{\mathrm{i}}$ of all 423 earthquake source models ranged from 0 to 22.77 and 33 yielded a $\Delta_{\mathrm{i}}$ value less than 7 (Appendix $E_{15}$ ). Four of these 33 earthquake models had a $\Delta_{i}$ value less than 2.0, indicating "substantial fits" (Figure 31). These models, 39_87_1, 44_87_2, 43_87_1, and 32_89_3, had RMSE values ranging from $0.11 \mathrm{~m}$ to $0.14 \mathrm{~m}$. The region of high slip for 
39_87_1, 44_87_2, and 43_87_1 were generally located on the northern segment of the fault model at $\sim 37^{\circ} \mathrm{S}$ to $\sim 38^{\circ} \mathrm{S}$ just north of the Mocha fracture zone at $\sim 38^{\circ} \mathrm{S}$ to $\sim$ $38.5^{\circ} \mathrm{S}$ (Figure 32). Earthquake source model 39_89_3 was a rupture on the southern segment of the fault model with high slip occurring at $\sim 42^{\circ} \mathrm{S}$ (Figure 32).

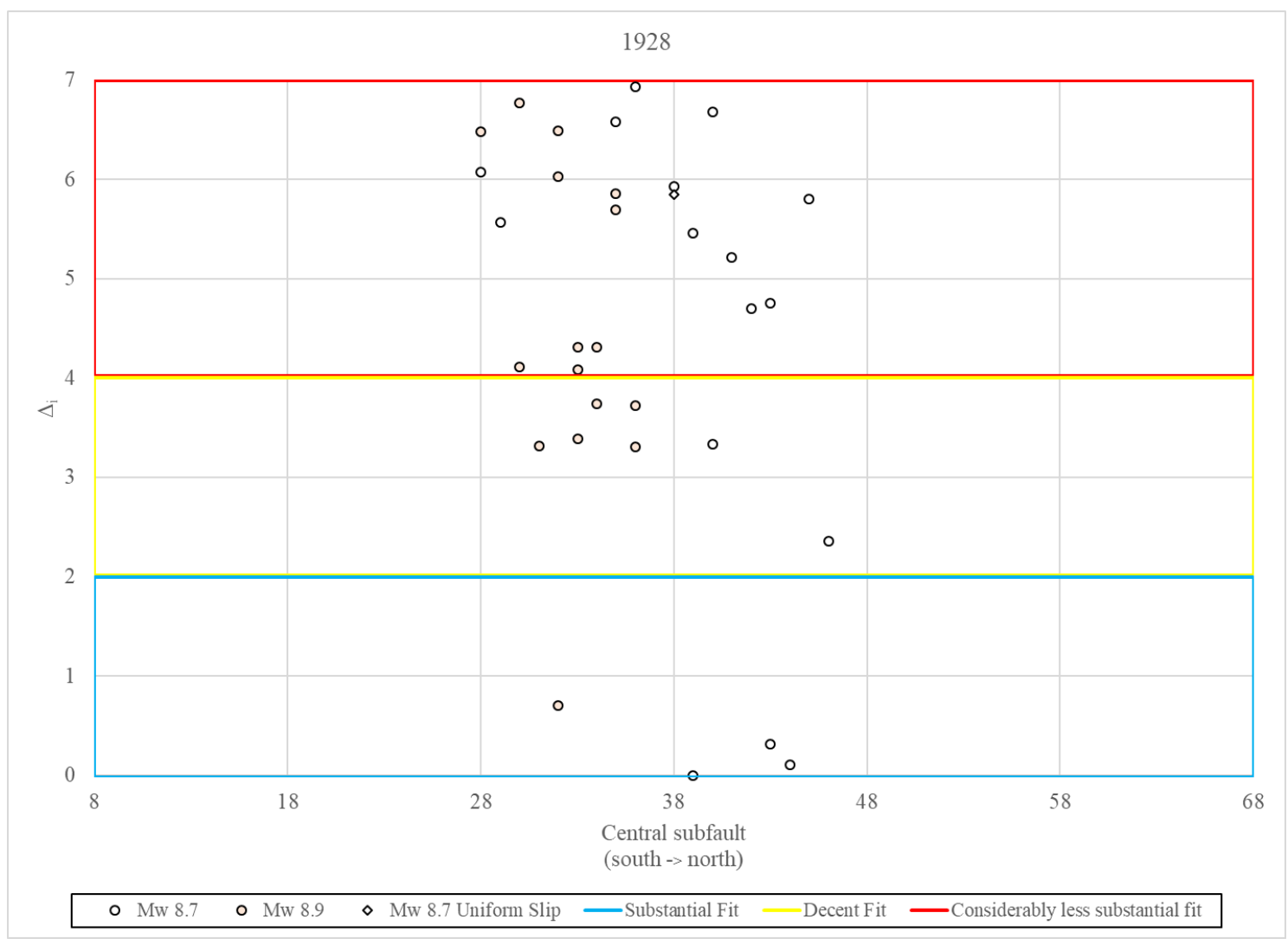

Figure 31: The 33 earthquake source models that yielded a $\Delta_{\mathrm{i}}<7.0$ when compared against the 1928 historical data. The tsunami simulations from earthquake source models 39_87_1, 44_87_2, 43_87_1, and 32_89_3 represent statistically substantial fits based on the historical tsunami data available for the 1928 event. 

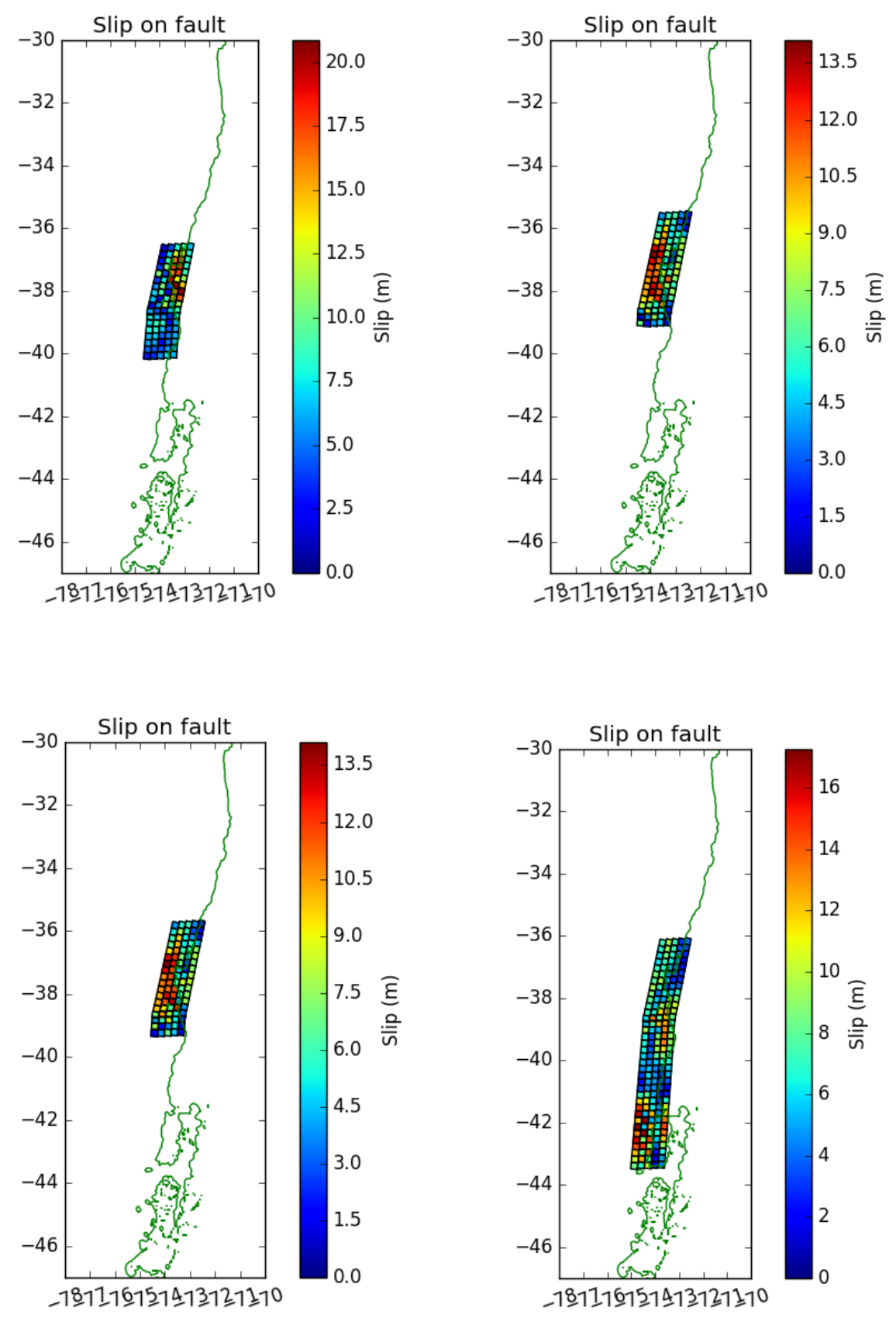

Figure 32: Potential rupture scenarios that were statistically significant, which yielded a $\Delta_{\mathrm{i}}$ value that suggests a substantial fit based on the AIC equations for the 1928 event: top left) model 39_87_1, top right) model 44_87_2, bottom left) 43_87_2, and bottom right) 32_89_3. 


\section{3 ts unami simulations}

The $1943 \mathrm{AIC}_{\mathrm{c}}$ analysis used only one tide gauge based on a single observation in the written record at Los Vilos (Appendix D; Table 1). The $\Delta_{\mathrm{i}}$ of all 423 earthquake source models ranged from 0 to 15.87 and 26 yielded a $\Delta_{\mathrm{i}}$ value less than 7 (Appendix $\left.\mathrm{E}_{16}\right)$. Three of these 26 earthquake models, had a $\Delta_{\mathrm{i}}$ value less than 2.0, indicating "substantial fits" (Figure 33). These models, 44_87_1, 40_89_3, and 41_89_3, had an RMSE value ranging between $0.03 \mathrm{~m}$ to $0.08 \mathrm{~m}$. The region of high slip for all three models are in the deeper part of the southern segment of the fault model at $\sim 37^{\circ} \mathrm{S}$, despite them varying in magnitudes. However, the $M_{w} 8.9$ source models also showed a region of greater shallow slip farther south between $\sim 40^{\circ} \mathrm{S}$ and $\sim 41^{\circ} \mathrm{S}$ (Figure 34). 


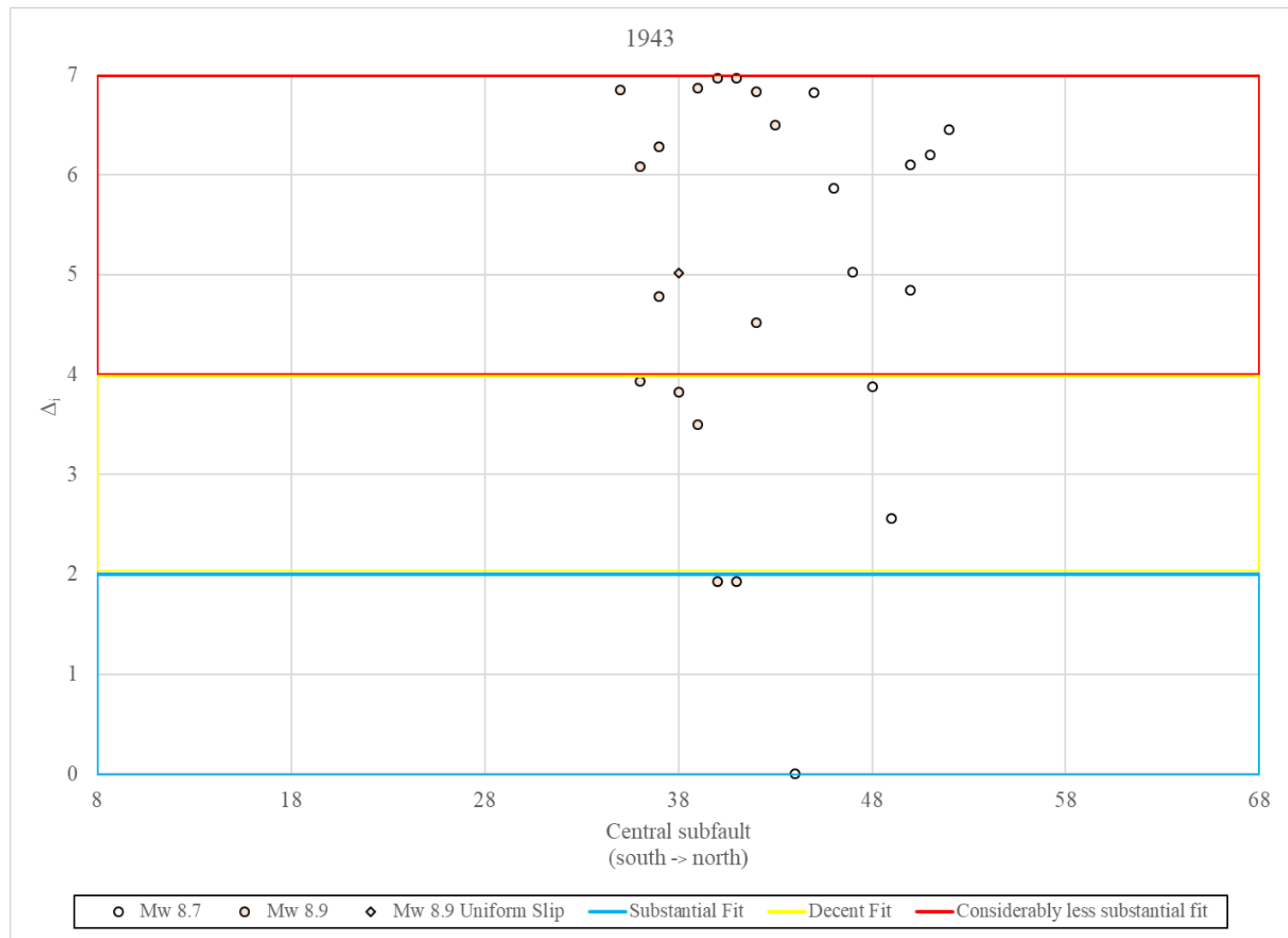

Figure 33: The 26 earthquake source models that yielded a $\Delta_{\mathrm{i}}<7.0$ when compared against the 1943 historical data. The tsunami simulations from earthquake source models 44_87_1, 40_89_3, and 41_89_3 represent statistically substantial fits based on the historical tsunami data available for the 1943 event. 

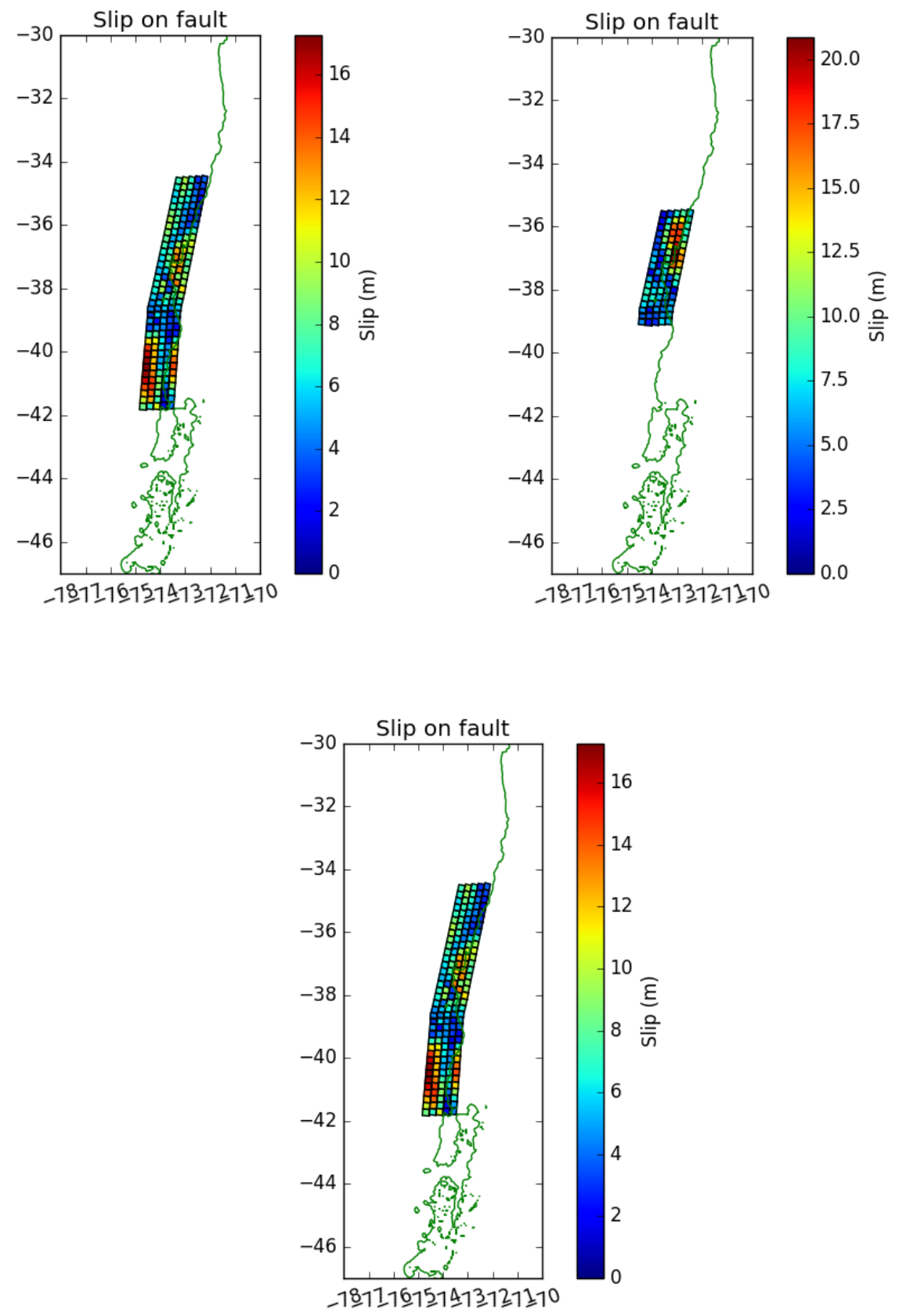

Figure 34: Potential rupture scenarios that were statistically significant, which yielded a $\Delta_{\mathrm{i}}$ value that suggests a substantial fit based on the AIC equations for the 1943 event: left) model 44_87_1, right) model 40_89_3, and bottom) model 41_89_3 


\section{CHAPTER V \\ 1960 RESULTS}

\section{Ts unami Simulations}

The $1960 \mathrm{AIC}_{\mathrm{c}}$ analysis used 30 tide gauges (Appendix D), of which 19 gauges were based on observations in the written record, while 11 gauges correlated to accounts within the geologic record (Table 1). The $\Delta_{\mathrm{i}}$ of all 423 earthquake source models ranged from 0 to 102.86 and 58 yielded a $\Delta_{\mathrm{i}}$ value less than 7 (Appendix $\mathrm{E}_{17}$ ). 16 out of the 58 statistically significant models had a $\Delta_{\mathrm{i}}$ value less than 2.0 , indicating "substantial fits" (Figure 35). Two of these 16 substantial fits were from $M_{w} 9.3$ earthquake source models (39_93_1 and 37_93_1), while 14 were from $\mathrm{M}_{\mathrm{w}} 8.7$ earthquake source models. The center of rupture for the $M_{w} 8.7$ earthquakes varied $299 \mathrm{~km}$ along strike and included slip distributions \#1, \#2, and \#3. The RMSE values of these 16 substantial fits ranged from $2.54 \mathrm{~m}$ to $3.84 \mathrm{~m}$, with the $\mathrm{M}_{\mathrm{w}} 9.3$ earthquake source numbers being more than a meter less than the $M_{w} 8.7$ earthquake source models. The main region of high slip for the $M_{w}$ 9.3 source models and the majority of $\mathrm{M}_{\mathrm{w}} 8.7$ models were located similarly at $\sim 39^{\circ} \mathrm{S}$. However, the $M_{w} 9.3$ earthquake source models also suggested there was shallow, high slip in the north or south at $\sim 33^{\circ} \mathrm{S}$ and $\sim 41^{\circ} \mathrm{S}$, respectively (Figure 36). The published earthquake source model by Barrientos and Ward (1990) (refer to Similarities of the "Barrientos slip" to AIC selected models in the Discussion chapter) had a $\Delta_{\mathrm{i}}$ value of 17.25, suggesting that this model had essentially no statistical significance. 


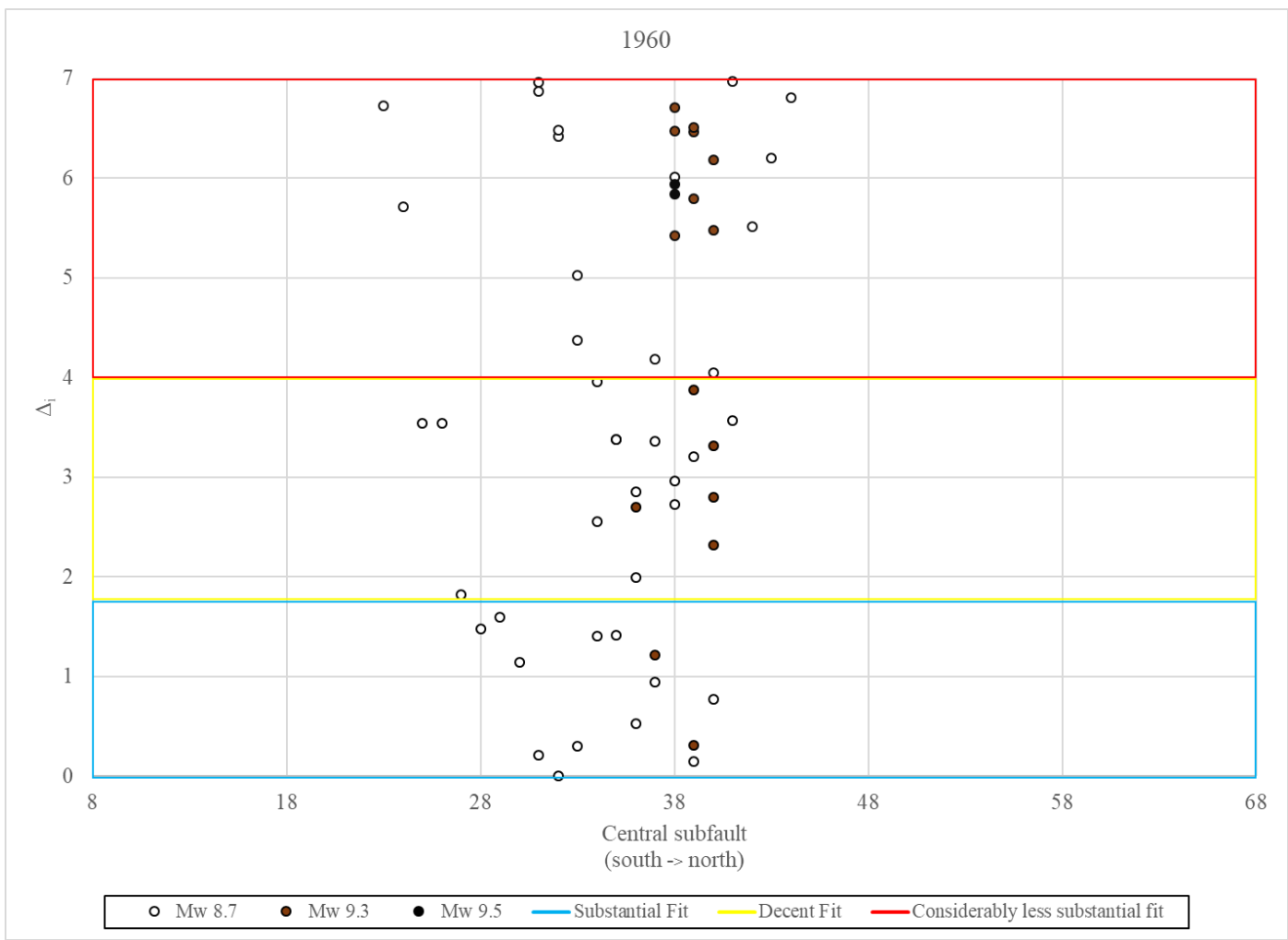

Figure 35: The 58 earthquake source models that yielded a $\Delta_{\mathrm{i}}<7.0$ when compared against the 1960 historical data. The two tsunami simulations from $M_{w} 9.3$ earthquake source models and 14 tsunami simulations from $M_{w} 8.7$ earthquake source models represent statistically substantial fits based on the historical tsunami data available for the 1960 event. 

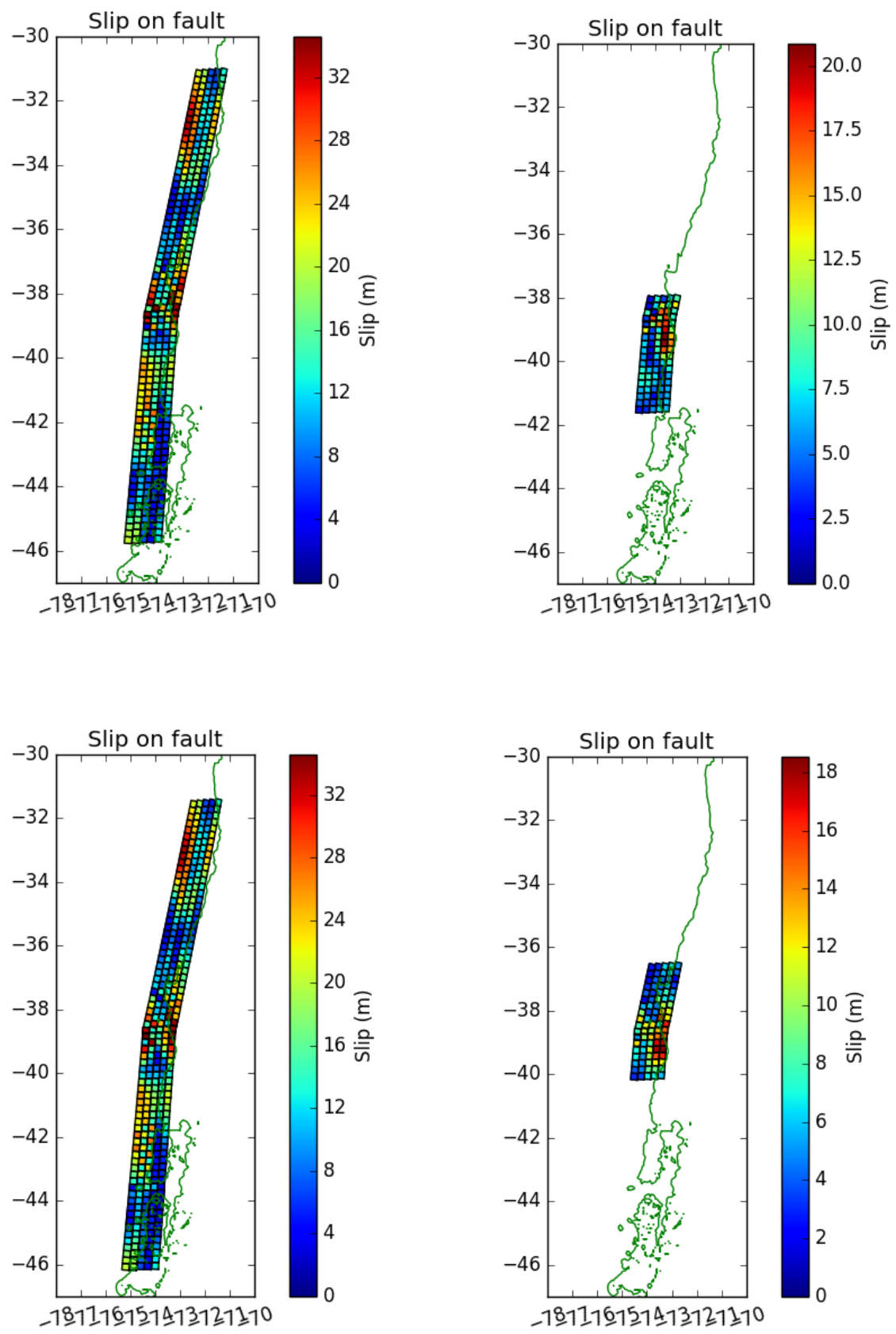

Figure 36: Potential rupture scenarios that were statistically significant, which yielded a $\Delta_{\mathrm{i}}$ value that suggests a substantial fit based on the AIC equations for the 1960 event: top left) model 39_93_1, top right) 32_87_1, bottom left) model 37_93_1, and bottom right) model 39_87_3. 


\section{High-re solution bathymetry for 1960 analysis}

The 1960 AIC analysis showed that 33 earthquake source models had a $\Delta_{\mathrm{i}}$ less than 4.0, which can be narrowed down further using high resolution bathymetry by simulating on-land inundation using $1 / 3$ arc-second high resolution topography at three locations (Tirúa, Quidico, and Puerto Saavedra). Out of the top 33 models determined by the AIC analysis, 16 simulations successfully inundated Tirúa, 21 in Quidico, and 2 in Puerto Saavedra. The two models that matched the data from Puerto Saavedra (40_93_7 and 39_93_7; Table 4) were both in the group of models that matched observations at Tirúa and Quidico. These two source models are of the same slip distribution only offset by $23 \mathrm{~km}$ along strike (Figure 37; Figure 38).

Table 4: Inundation comparison for three locations using earthquake source models that yielded a $\Delta_{\mathrm{i}}$ value less than 4.0 for the 1960 event. 'O' shows models with inundation at tsunami observation/deposit sites, while an ' $\mathrm{X}$ ' shows water stopping short of those sites.

\begin{tabular}{|l|c|c|c|c|}
\hline Source model & $\boldsymbol{\Delta}_{\mathbf{i}}$ & Tirúa & Quidico & $\begin{array}{c}\text { Puerto } \\
\text { Saavedra }\end{array}$ \\
\hline 32_87_1 & $<2$ & $\mathrm{X}$ & $\mathrm{O}$ & $\mathrm{X}$ \\
\hline 39_87_3 & $<2$ & $\mathrm{X}$ & $\mathrm{X}$ & $\mathrm{X}$ \\
\hline 31_87_1 & $<2$ & $\mathrm{X}$ & $\mathrm{O}$ & $\mathrm{X}$ \\
\hline 33_87_1 & $<2$ & $\mathrm{O}$ & $\mathrm{O}$ & $\mathrm{X}$ \\
\hline 39_93_1 & $<2$ & $\mathrm{X}$ & $\mathrm{O}$ & $\mathrm{X}$ \\
\hline 36_87_2 & $<2$ & $\mathrm{O}$ & $\mathrm{O}$ & $\mathrm{X}$ \\
\hline 40_87_3 & $<2$ & $\mathrm{X}$ & $\mathrm{X}$ & $\mathrm{X}$ \\
\hline 37_87_2 & $<2$ & $\mathrm{O}$ & $\mathrm{O}$ & $\mathrm{X}$ \\
\hline 30_87_1 & $<2$ & $\mathrm{X}$ & $\mathrm{O}$ & $\mathrm{X}$ \\
\hline 37_93_1 & $<2$ & $\mathrm{X}$ & $\mathrm{X}$ & $\mathrm{X}$ \\
\hline 34_87_1 & $<2$ & $\mathrm{O}$ & $\mathrm{O}$ & $\mathrm{X}$ \\
\hline 35_87_1 & $<2$ & $\mathrm{O}$ & $\mathrm{O}$ & $\mathrm{X}$ \\
\hline
\end{tabular}




\begin{tabular}{|l|c|c|c|c|}
\hline Model & $\boldsymbol{\Delta}_{\mathbf{i}}$ & $\boldsymbol{\Delta}_{\mathbf{i}}$ Rank & RMSE $(\mathbf{m})$ & RMSE Rank \\
\hline 29_87_1 & $<2$ & $\mathrm{O}$ & $\mathrm{O}$ & $\mathrm{X}$ \\
\hline 27_87_1 & $<2$ & $\mathrm{O}$ & $\mathrm{O}$ & $\mathrm{X}$ \\
\hline 36_87_1 & $<2$ & $\mathrm{O}$ & $\mathrm{O}$ & $\mathrm{X}$ \\
\hline 40_93_1 & $<4$ & $\mathrm{O}$ & $\mathrm{O}$ & $\mathrm{X}$ \\
\hline 34_87_2 & $<4$ & $\mathrm{O}$ & $\mathrm{O}$ & $\mathrm{X}$ \\
\hline 36_93_1 & $<4$ & $\mathrm{X}$ & $\mathrm{O}$ & $\mathrm{X}$ \\
\hline 38_87_3 & $<4$ & $\mathrm{X}$ & $\mathrm{X}$ & $\mathrm{X}$ \\
\hline 40_93_2 & $<4$ & $\mathrm{O}$ & $\mathrm{O}$ & $\mathrm{X}$ \\
\hline 36_87_3 & $<4$ & $\mathrm{X}$ & $\mathrm{O}$ & $\mathrm{X}$ \\
\hline 38_87_2 & $<4$ & $\mathrm{O}$ & $\mathrm{O}$ & $\mathrm{X}$ \\
\hline 39_87_2 & $<4$ & $\mathrm{O}$ & $\mathrm{X}$ & $\mathrm{X}$ \\
\hline 40_93_7 & $<4$ & $\mathbf{O}$ & $\mathbf{O}$ & $\mathbf{O}$ \\
\hline 37_87_3 & $<4$ & $\mathrm{X}$ & $\mathrm{X}$ & $\mathrm{X}$ \\
\hline 35_87_3 & $<4$ & $\mathrm{X}$ & $\mathrm{X}$ & $\mathrm{X}$ \\
\hline 35_87_2 & $<4$ & $\mathrm{X}$ & $\mathrm{X}$ & $\mathrm{X}$ \\
\hline 25_87_1 & $<4$ & $\mathrm{X}$ & $\mathrm{X}$ & $\mathrm{X}$ \\
\hline 26_87_1 & $<4$ & $\mathrm{X}$ & $\mathrm{X}$ & $\mathrm{X}$ \\
\hline 41_87_3 & $<4$ & $\mathrm{X}$ & $\mathrm{X}$ & $\mathrm{X}$ \\
\hline 39_93_7 & $<4$ & $\mathbf{O}$ & $\mathbf{O}$ & $\mathbf{O}$ \\
\hline 34_87_3 & $<4$ & $\mathrm{X}$ & $\mathrm{X}$ & $\mathrm{X}$ \\
\hline Total & - & $\mathbf{1 6}$ & $\mathbf{2 1}$ & $\mathbf{2}$ \\
\hline
\end{tabular}



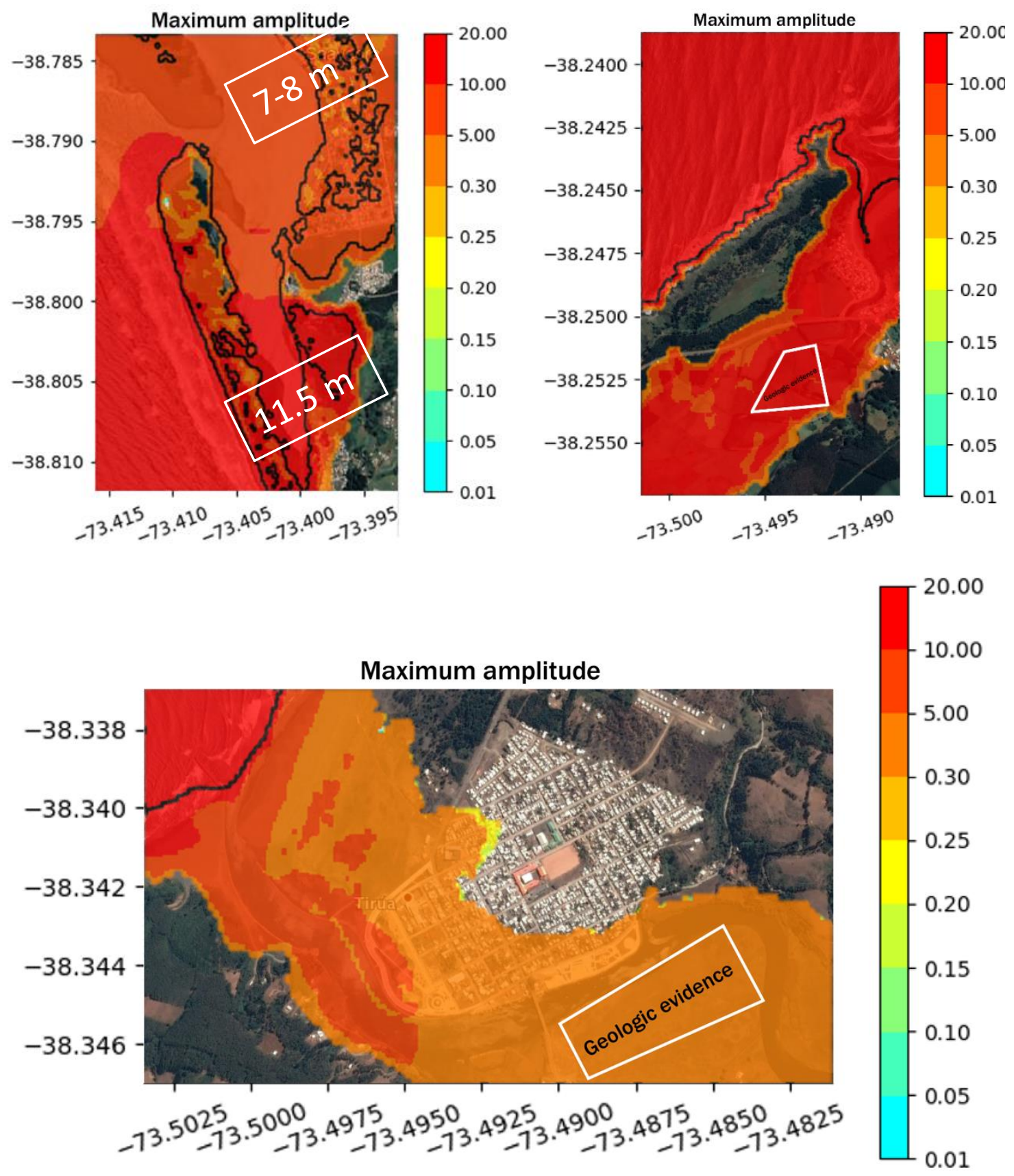

Figure 37: Maximum tsunami elevationat Puerto Saavedra (left), Quidico (right), and Tirúa (bottom) from earthquake source model 40_93_7. The scale bar is in meters. The tsunami simulation from this source model matched the geologic evidence recorded at Quidico and Tirúa, in addition to matching the 7-8 $\mathrm{m}$ wave height in the village of Puerto Saavedra and an $11.5 \mathrm{~m}$ wave height in the southern portion of the bay. 

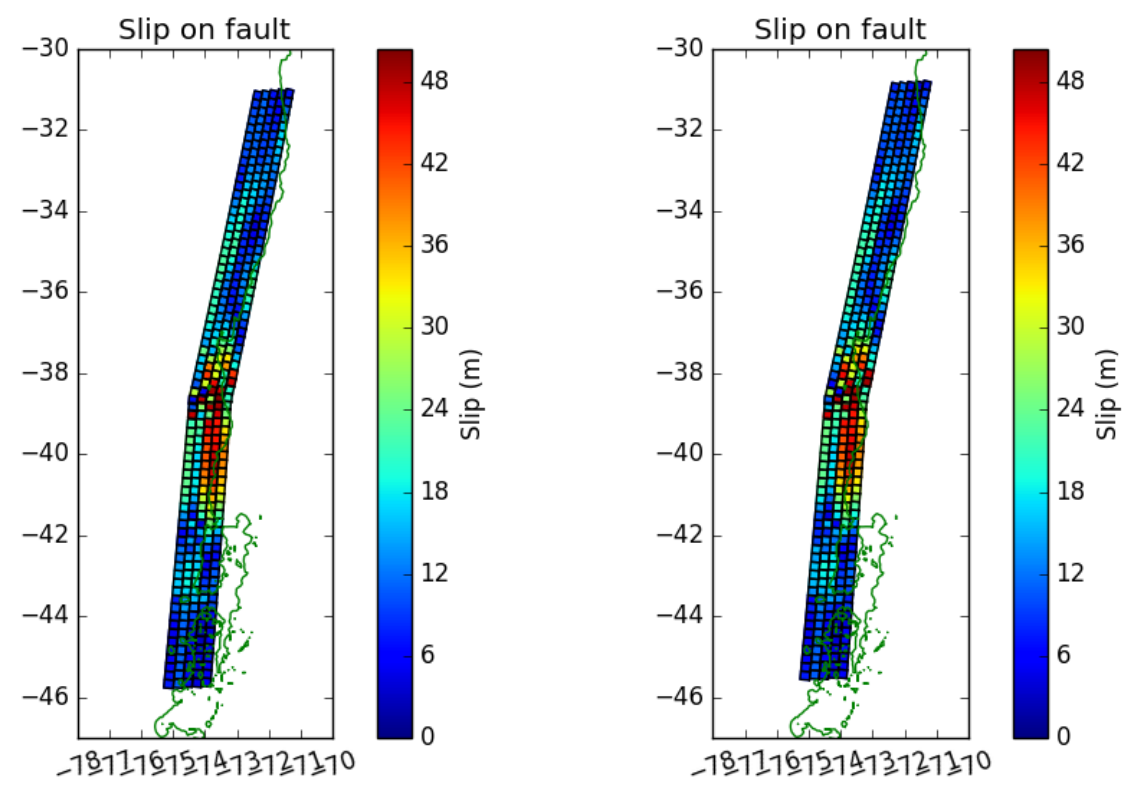

Figure 38: Potential rupture scenarios for earthquake source models 39_93_7 (left) and 40_93_7 (right), which successfully matched the inundation dynamics at Puerto Saavedra, Quidico, and Tirúa.

\section{Total water displacement of "best-fitting" 1960 models}

The total volume of water displaced from a tsunami was correlative to the magnitude of the earthquake source model. Out of the top 33 best-fitting earthquake source models for the 1960 event and the top two $\mathrm{M}_{\mathrm{w}} 9.5$ source models $\left(\mathrm{AIC}_{\mathrm{c}}\right.$ ranks \#43 and \#44), the tsunami simulations derived from the $\mathrm{M}_{\mathrm{w}} 9.5$ source models displaced the most amount of water (Table 5). Following the $M_{w} 9.5$ tsunami simulations, the $M_{w} 9.3$ tsunami simulations all displaced a greater volume of water than the $M_{w} 8.7$ tsunami simulations by an order of magnitude, and the $\left(M_{w} 9.0\right)$ Barrientos and Ward (1990) source model (Table 5). 
Table 5: The amount of total water displaced for all 1960 tsunami simulations with a $\Delta_{\mathrm{i}}$ $<4$, the two best-fitting $\mathrm{M}_{\mathrm{w}} 9.5$ tsunami simulations, and the tsunami simulation derived from the Barrientos and Ward (1990) $\mathrm{M}_{\mathrm{w}} 9.0$ earthquake source model.

\begin{tabular}{|c|c|c|c|c|}
\hline $\begin{array}{c}\text { Dis placed water } \\
\text { rank }\end{array}$ & $\begin{array}{l}\text { Earthquake } \\
\text { model }\end{array}$ & $\begin{array}{c}\text { Volume of } \\
\text { total water } \\
\text { displaced } \\
\left(\mathrm{m}^{3}\right)\end{array}$ & $\Delta_{\mathbf{i}}$ & $\begin{array}{l}\mathrm{AIC}_{\mathbf{c}} \\
\text { rank }\end{array}$ \\
\hline 1 & 38_95_3 & $2.34 \times 10^{15}$ & 5.94 & 44 \\
\hline 2 & 38_95_7 & $2.07 \times 10^{15}$ & 5.84 & 43 \\
\hline 3 & 39_93_7 & $1.27 \times 10^{15}$ & 3.87 & 32 \\
\hline 4 & 40_93_7 & $1.27 \times 10^{15}$ & 2.80 & 25 \\
\hline 5 & 40_93_2 & $1.03 \times 10^{15}$ & 2.32 & 21 \\
\hline 6 & 36_93_1 & $1.02 \times 10^{15}$ & 2.70 & 19 \\
\hline 7 & 37_93_1 & $1.02 \times 10^{15}$ & 1.21 & 10 \\
\hline 8 & 39_93_1 & $1.01 \times 10^{15}$ & 0.31 & 5 \\
\hline 9 & 40_93_1 & $1.01 \times 10^{15}$ & 2.32 & 17 \\
\hline 10 & Barrientos_Slip & $5.79 \times 10^{14}$ & 15.37 & 155 \\
\hline 11 & 27_87_1 & $2.05 \times 10^{14}$ & 1.82 & 15 \\
\hline 12 & 28_87_1 & $2.05 \times 10^{14}$ & 1.48 & 13 \\
\hline 13 & 29_87_1 & $2.03 \times 10^{14}$ & 1.60 & 14 \\
\hline 14 & 30_87_1 & $2.02 \times 10^{14}$ & 1.14 & 9 \\
\hline 15 & $32 \_87 \_1$ & $2.01 \times 10^{14}$ & 0.00 & 1 \\
\hline 16 & 31_87_1 & $2.01 \times 10^{14}$ & 0.21 & 3 \\
\hline 17 & 34_87_3 & $2.01 \times 10^{14}$ & 3.95 & 33 \\
\hline 18 & $33 \_87 \_1$ & $2.00 \times 10^{14}$ & 0.30 & 4 \\
\hline 19 & 36_87_3 & $2.00 \times 10^{14}$ & 2.85 & 22 \\
\hline 20 & $35 \_87 \_3$ & $2.00 \times 10^{14}$ & 3.38 & 27 \\
\hline 21 & 35_87_2 & $2.00 \times 10^{14}$ & 3.38 & 28 \\
\hline 22 & 37_87_3 & $2.00 \times 10^{14}$ & 3.35 & 26 \\
\hline 23 & 34_87_1 & $2.00 \times 10^{14}$ & 1.41 & 11 \\
\hline 24 & $40 \_87 \_3$ & $1.99 \times 10^{14}$ & 0.77 & 7 \\
\hline 25 & 38_87_3 & $1.98 \times 10^{14}$ & 2.73 & 20 \\
\hline 26 & 39_87_3 & $1.98 \times 10^{14}$ & 0.15 & 2 \\
\hline 27 & 41_87_3 & $1.98 \times 10^{14}$ & 3.57 & 31 \\
\hline 28 & 35_87_1 & $1.97 \times 10^{14}$ & 1.42 & 12 \\
\hline 29 & 36_87_1 & $1.97 \times 10^{14}$ & 1.99 & 16 \\
\hline
\end{tabular}




\begin{tabular}{|c|c|c|c|c|}
\hline $\begin{array}{c}\text { Displaced water } \\
\text { rank }\end{array}$ & $\begin{array}{c}\text { Earthquake } \\
\text { model }\end{array}$ & $\begin{array}{c}\text { Volume of } \\
\text { total water } \\
\text { displaced } \\
\left(\mathbf{m}^{\mathbf{3}}\right)\end{array}$ & $\boldsymbol{\Delta}_{\mathbf{i}}$ & $\begin{array}{c}\mathbf{A I C}_{\mathbf{c}} \\
\text { rank }\end{array}$ \\
\hline 30 & $34 \_87 \_2$ & $1.39 \times 10^{14}$ & 2.56 & 18 \\
\hline 31 & $36 \_87 \_2$ & $1.38 \times 10^{14}$ & 0.52 & 6 \\
\hline 32 & 39_87_2 & $1.37 \times 10^{14}$ & 3.21 & 24 \\
\hline 33 & 37_87_2 & $1.37 \times 10^{14}$ & 0.94 & 8 \\
\hline 34 & 38_87_2 & $1.36 \times 10^{14}$ & 2.96 & 23 \\
\hline 35 & 25_87_1 & $1.20 \times 10^{14}$ & 3.54 & 29 \\
\hline 36 & 26_87_1 & $1.20 \times 10^{14}$ & 3.54 & 30 \\
\hline
\end{tabular}

In general, tsunami simulations derived from the same magnitudes displace a similar volume of water. Within the top $\mathrm{AIC}_{\mathrm{c}}$ source models for the 1960 event, the $\mathrm{M}_{\mathrm{w}}$ 8.7 and $\mathrm{M}_{\mathrm{w}} 9.3$ tsunami simulations can each be grouped into two clusters of total volume of water displaced (Figure 39). Models 40_93_7 and 39_93_7— the only simulations within the top $\mathrm{AIC}_{\mathrm{c}} 33$ that generated large enough waves to match the wave heights at Puerto Saavedra — stand out as having a greater volume of displaced water than the rest of the $M_{w} 9.3$ source models as they fit into a higher cluster (Figure 39). 


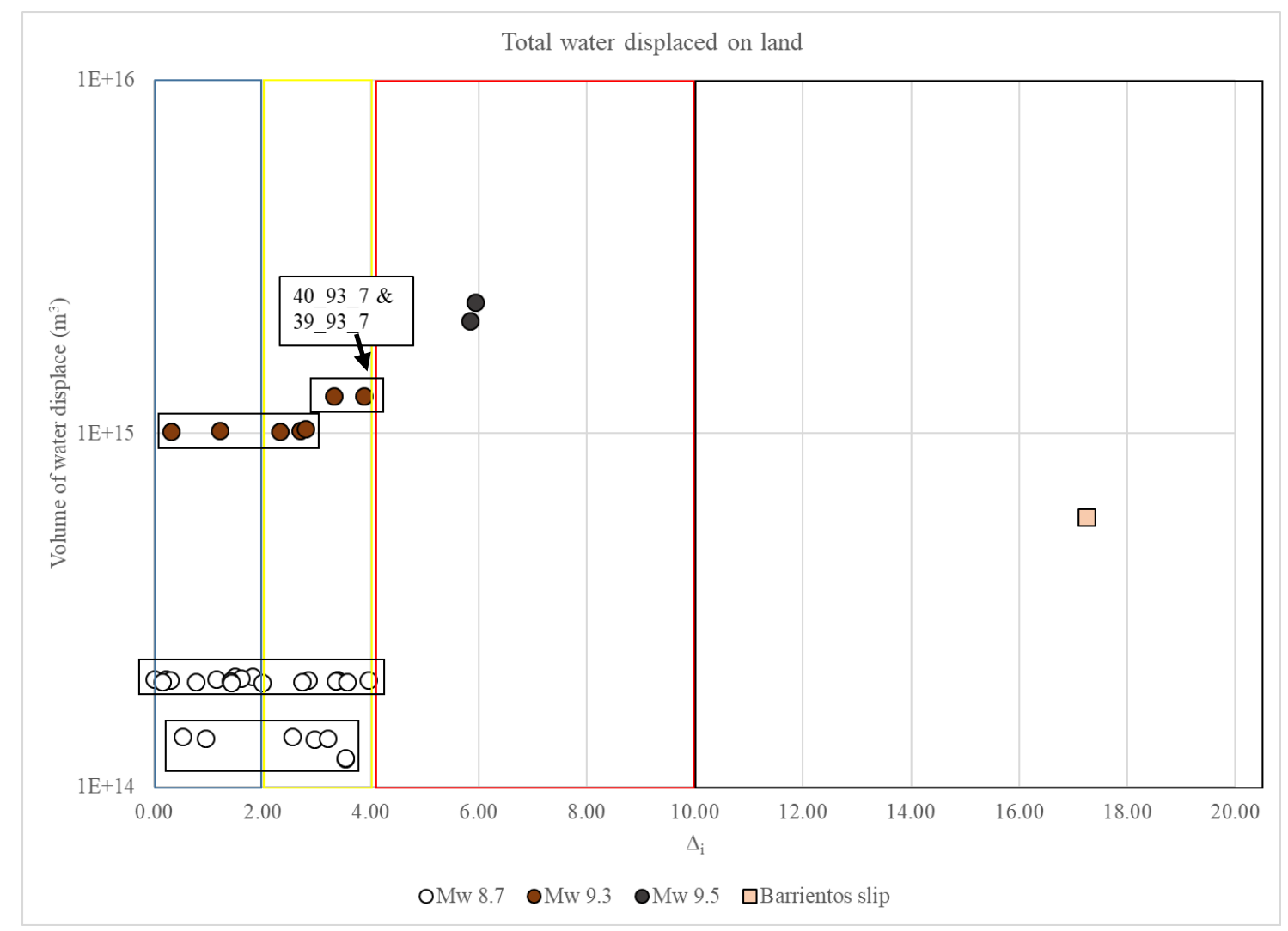

Figure 39: The volume of water displaced from the top 33 "best-fitting" tsunami simulations to the 1960 event, in addition to two $M_{w} 9.5$ tsunami simulations and the tsunami simulation derived from the Barrientos and Ward (1990) $\mathrm{M}_{\mathrm{w}} 9.3$ earthquake source model. The colored boxes represent the $\Delta_{\mathrm{i}}$ zones of significance $(0-2=$ substantial significance, 3-4 = decent significance, 4-6 = considerably less significance, $>10=$ essentially no significance). 


\section{CHAPTER VI}

\section{DISCUSSION}

\section{Variable slip models are better than uniform slip models}

The earthquake source models in this research use stochastic variable slip

solutions. However, to test whether stochastic variable slip solutions were more valuable than other solutions, a few centrally located uniform slip solutions on the same fault model as the variable slip solutions were also analyzed. In almost all earthquake analyses, the uniform slip scenarios plotted in the $\Delta_{\mathrm{i}}$ category of having "essentially no" statistical significance and typically the uniform slip sources plotted worse than the variable earthquake source models that ruptured the same areas (Appendix E). Some exceptions include the 1657 analysis where all earthquake sources yielded $\Delta_{\mathrm{i}}$ values less than 6.0, both 1871 and 1943 where the $\mathrm{M}_{\mathrm{w}} 8.9$ uniform slip source was one of those in the "considerably less substantial fit" category, and the 1928 event where the $M_{w} 8.7$ uniform slip source was one of the "considerably less substantial fit" sources. The last exception was the 1927 analysis, which showed all earthquake source models having the same result (this special case is addressed in the following section, AIC statistical analyses are effective). These results are not surprising considering that earthquakes are known to not rupture uniformly across a fault area (Mikumo and Miyatake, 1978; Mai and Beroza, 2002; Moreno et al., 2010; Wang et al., 2013). Thus, when evaluating potential rupture characteristics for historical events, earthquakes with uniform slip are too simple and if possible, should not be considered. 


\section{AIC statis tical analyses are effective}

To evaluate the accuracy of using $\mathrm{AIC}_{\mathrm{c}}$ as a method to determine "good-fitting" earthquake source models for a given earthquake event, I also analyzed the weighted root mean square error (RMSE) average of all tide gauges for each earthquake source model. The RMSE value declares an absolute measure of fit with lower values indicating better fit (e.g. a RMSE value of $1 \mathrm{~m}$ indicates that the modeled wave height is on average either $1 \mathrm{~m}$ higher or lower than the observed wave height in the historical record). The mean RMSE value in all model solutions, with the exception to $1570,1575,1837,1871 \mathrm{~b}$, and 1906, was above $4.00 \mathrm{~m}$ with a standard deviation between $0.59 \mathrm{~m}$ to $16.01 \mathrm{~m}$. This indicates that the majority of models have a range of "good-fitting" solutions as well as "poor fitting" solutions (Table 6). In the case of the listed exceptions, other than 1575, the locations of observations are not sensitive (yield too similar simulated values) enough to differentiate the majority of the earthquake source solutions. Disregarding the unusual 1927 earthquake event (Table 6), the RMSE value of the lowest $\Delta_{\mathrm{i}}$ earthquake source model is small, which supports that the AIC analysis is valid in ranking models out of the dataset with "good-fitting" and "poor-fitting" models. This agreement between both low RMSE and $\Delta_{\mathrm{i}}$ values suggests that the models that correspond to the best absolute measure of fit for all observations is being selected. However, in two earthquake analyses, the source model with the lowest $\Delta_{\mathrm{i}}$ value was not the same model with the lowest RMSE value. In those two cases, 1835 and 1960 earthquakes, the larger $\mathrm{M}_{\mathrm{w}} 9.3$ and $\mathrm{M}_{\mathrm{w}} 9.5$ earthquake source model had a worse $\Delta_{\mathrm{i}}$ value, but better RMSE value than 
the smaller $M_{w} 8.7$ models. This discrepancy may either have to do with these smaller earthquake source models overfitting the main bulk of historical wave height data for each respective analysis (this issue is discussed further in the Why do smaller earthquake solutions fit well for 1960? section of this chapter), or because the larger earthquake source models rupture a greater number of subfaults. Larger source models that rupture a greater number of subfaults have more sensitively associated with its $\Delta_{\mathrm{i}}$ value than the smaller source models as there are more parameters (number of subfaults) being analyzed in the AIC equations (Burnham and Anderson, 2002). 
Table 6: RMSE values (m) of the "best-fitting" earthquake solution for each historical event based on the AIC equations, in addition to the mean RMSE and standard deviation of all solutions for a given historical event.

\begin{tabular}{|c|c|c|c|}
\hline Earthquake event & Top $\boldsymbol{\Delta}_{\mathbf{i} \text { model }}$ & $\begin{array}{c}\text { Top RMSE } \\
\text { value (m) }\end{array}$ & $\begin{array}{c}\text { Mean RMSE } \\
\text { standard } \\
\text { de viation (m) }\end{array}$ \\
\hline 1570 & 38_90_3 & 0.23 & $2.96 \pm 1.88$ \\
\hline 1575 & 39_93_8 & 0.12 & $0.59 \pm 0.19$ \\
\hline 1657 & 36_93_3 & 1.84 & $19.97 \pm 7.34$ \\
\hline 1730 & 39_93_10 & 0.72 & $7.48 \pm 2.68$ \\
\hline 1751 & 57_87_3 & 2.24 & $4.46 \pm 1.08$ \\
\hline 1822 & 59_87_2 & 0.72 & $5.28 \pm 3.54$ \\
\hline 1835 & 46_87_1 & 3.59 & $6.04 \pm 0.82$ \\
\hline 1837 & 52_87_2 & 0.84 & $3.43 \pm 2.89$ \\
\hline 1871 & 52_87_2 & 0.02 & $11.75 \pm 14.63$ \\
\hline $1871 b$ & 37_93_9 & 0.02 & $2.49 \pm 1.37$ \\
\hline 1898 & 17_87_2 & 0.01 & $10.21 \pm 9.07$ \\
\hline 1906 & 31_87_1 & 1.45 & $3.11 \pm 2.01$ \\
\hline 1920 & 24_87_1 & 0.29 & $5.48 \pm 5.22$ \\
\hline 1927 & 89_uniform_slip & 5.95 & $5.95 \pm 7.95 \times 10-07$ \\
\hline 1928 & 39_87_1 & 0.11 & $5.82 \pm 5.29$ \\
\hline 1943 & 44_87_1 & 0.03 & $12.31 \pm 16.01$ \\
\hline 1960 & 32_87_1 & 3.71 & $4.13 \pm 0.59$ \\
\hline
\end{tabular}

Overall, many of the earthquakes have few $(<3)$ historical wave height observations (e.g. 1657, 1871, 1871b, 1898, 1927, 1928, and 1943), which inherently biases the RMSE value because wave heights are compared against fewer data points. This becomes evident when analyzing the standard deviation of values; events with less than three observations have higher standard deviations than events with greater than three observations. Additionally, for events with only one observation (e.g. 1657, 1871, 1871b, 1898, and 1943), it does not make sense to analyze a weighted RMSE analysis. 
For example, the mean RMSE and standard deviation for the 1657 event was $19.97 \pm$ $7.34 \mathrm{~m}$. These values disagree with the range of $\Delta_{\mathrm{i}}$ values and suggests that there were large differences in maximum wave heights from varying source models. This inconsistency between the ranges of the $\Delta_{\mathrm{i}}$ and RMSE values is partly a result of the scaling factor in the $\mathrm{AIC}_{\mathrm{c}}$ equation (the $\mathrm{AIC}_{\mathrm{c}}$ result may be indicating that RMSE is not a good method to use when only one observation is available). Another issue resides with using a weighted RMSE values for analyses with one gauge. The original weighted values from the residual sum of squares (RSS) in the AIC equations are not standardized to 1.0 when only one observation is involved. Thus, the large RMSE and standard deviation values, such as $19.97 \pm 7.34 \mathrm{~m}$, are not representing an absolute measure of fit in these cases. Instead, it is necessary to analyze other factors, like residuals or the range of $\Delta_{\mathrm{i}}$ values when only one observation is used for an event.

Analyzing the $\Delta_{\mathrm{i}}$ values in detail helps to test the validity of these models results. Events with higher statistical analyses confidence should have an overall $\Delta_{\mathrm{i}}$ range that is greater than 10.0 and few simulations yielding a $\Delta_{\mathrm{i}}$ less than 2.0. The $\Delta_{\mathrm{i}}$ value is dependent upon the lowest $\mathrm{AIC}_{\mathrm{c}}$ model within the set of simulated earthquake source models. A $\Delta_{\mathrm{i}}$ value cannot be intrinsically evaluated for goodness of fit within the AIC equations alone. However, if the range in overall $\Delta_{\mathrm{i}}$ is too small $(<10.0)$, it suggests that all earthquake source models are too similar to be selected as truly substantially significant. 
As such, two earthquakes, 1657 and 1927 can therefore be ruled out as having invalid results. The small range of $\Delta_{\mathrm{i}}$ values for the 1657 and 1927 events suggest that the corresponding wave heights at the relevant tide gauges in each tsunami simulation were too similar to truly select statistically significant earthquake source scenarios. In part, the statistical failure of 1927 has to do with the resolution of bathymetry and topography. The 1927 event relied on placed tide gauges near Puerto Aysen and Puerto Cisnes. The 30 arc-second bathymetry used in these simulations interpreted the narrow fjords of the Puerto Aysen region as land, which restricted any tsunami propagation. Therefore, no tsunami simulation could inundate these tide gauges; if a finer bathymetric grid was available and used, inundation could be possible to properly evaluate the observations from these fjords.

The 1657 event's failure is due to the lack of historical data available; only one wave height at Penco was used in the AIC statistical analysis. However, the 1871, 1871b, 1898, and 1943 events also had only one historical data point at other tide gauge locations. Therefore, I assume that the tide gauge location at Penco (eastern part of Concepción Bay) is less sensitive to different rupture characteristics within the earthquake source models than other gauges (located at Valparaíso, Puerto Montt, the southern end of Concepción Bay, and Los Vilos, respectively). The geometry of eastern part of Concepción Bay, which is adjacent to Penco, may play a role in limiting the ability to differentiate waves from various tsunami simulations. However, out of all the earthquake events with one data point, the 1898 event also was analyzed with a gauge 
placed in a portion of this bay. The $1898 \Delta_{\mathrm{i}}$ range was 18.48 , perhaps indicating a greater sensitivity at the southern portion of Concepción Bay than the eastern portion adjacent to Penco.

\section{Historical magnitudes match simulated es timations}

The AIC equations identified suites of earthquake source models, compared to all source models in this study, that most-closely match observations of 17 known earthquake events. An important caveat is that the selected earthquake source models do not directly determine earthquake magnitude. This is because only localized historical tsunami wave heights were used as a variable in the selection process within this method. An accurate moment magnitude interpreted from only tsunami observations requires modeling additional data that this research does not address (e.g. observed land level changes and shaking intensities). There are also many tsunami modeling assumptions in these calculations, such as the process of correlating slip to seafloor deformation and whether horizontal deformation plays a role in tsunami generation. Instead, the suite of best source models defined probable locations of greatest sea surface disturbance during an earthquake responsible for producing accurate tsunami runup and inundation observations along the coast. Because water moves as an incompressible fluid, seafloor deformation within the fault model directly influences generation of a tsunami (Berger et al., 2011). 
Model selection from the AIC statistical equations have made it apparent that slip distribution matters greatly. Earthquake sources of the same magnitude rupturing the same subfault area, but with different slip distributions showed wide $\mathrm{AIC}_{\mathrm{c}}$ ranges. For example, when evaluating the validity of the source models for the 1960 event, model 39_93_1 yielded a $\Delta_{\mathrm{i}}$ value of 0.31 , suggesting a statistically substantial fit, while model 39_93_10, a different slip distribution, yielded a $\Delta_{\mathrm{i}}$ value of 22.66, suggesting no statistical significance, despite rupturing the same area. Therefore, the position of where slip concentrations occur along the subduction zone appears to be the most critical factor for determining potential matches to historic ruptures.

That being said, the estimated magnitudes for these events in the literature still generally match well with the earthquake source model magnitudes chosen in the AIC model selection process (Table 7: Comparison table). For instance, the earthquake source simulations of the 1575, 1730,1751, and 1960 events agree with the previously estimated magnitudes. For the cases where the estimated magnitude of an event was less than a M 8.7 rupture, it would make sense that a $\mathrm{M}_{\mathrm{w}} 8.7$ source model would most-closely match as they were the smallest models simulated (e.g. 1835, 1837, 1871, 1898, 1906, 1920, and 1928). However, the results of these events are inherently overestimates and smaller earthquake source models should be analyzed. 
Table 7: Estimated magnitudes in the historical record (from the literature) versus estimated magnitudes from simulations.

\begin{tabular}{|c|c|c|}
\hline Event & $\begin{array}{c}\text { Historical record } \\
\text { estimation of magnitude } \\
(\mathrm{M})\end{array}$ & $\begin{array}{l}\text { Estimated magnitude } \\
\text { from simulations }\left(M_{w}\right)\end{array}$ \\
\hline 1570 & $8.0-8.5$ & 8.9 and 9.1 \\
\hline 1575 & Similar to 1960 & 9.3 \\
\hline 1657 & 8.0 & 8.7 and 9.3 \\
\hline 1730 & $9.1-9.3$ & 9.3 \\
\hline 1751 & 8.8 & $8.7,8.9$, and 9.3 \\
\hline 1822 & $8.0-8.5$ & 8.7 and 8.9 \\
\hline 1835 & $8.2-8.5$ & 8.7 \\
\hline 1837 & $8.0-8.5$ & 8.7 \\
\hline 1871 & 7.5 & 8.7 \\
\hline $1871 \mathrm{~b}$ & $\mathrm{n} / \mathrm{a}$ & $8.7,9.1$, and 9.3 \\
\hline 1898 & 6.5 & 8.7 \\
\hline 1906 & 8.2 & 8.7 \\
\hline 1920 & 7.0 & 8.7 \\
\hline 1927 & 7.2 & $\mathrm{n} / \mathrm{a}$ \\
\hline 1928 & 7.7 & 8.7 \\
\hline 1943 & 8.1 & 8.7 and 8.9 \\
\hline 1960 & 9.5 & 9.3 and 8.7 \\
\hline
\end{tabular}

For the 1570 1822, 1871b, and 1943 events, the AIC analysis overestimates the magnitudes relative to the historical estimations (Table 7: Comparison table), likely because these earthquakes have a large wave height in a localized region. The AIC analysis does not include gauges in locations with no observed wave height. However, a quick analysis of including " 0 's" for wave heights at tide gauges with no observations in all four of these analyses showed the $M_{w} 8.7$ earthquake source models yielded the best $\Delta_{\mathrm{i}}$. This result more closely resembles the estimated magnitudes from the historical 
record. Additionally, earthquakes larger than $M_{w} 8.7$ should have observed wave heights at multiple locations along the coast in the historical record because the tsunamis would cover a broad area. The largest historical tsunami events in Chile (e.g. 1575, 1730, 1835, and 1960) all had observed tsunami runup in multiple areas along the coast or paleotsunami evidence as opposed to runup in one localized region. Therefore, earthquakes $>M_{w} 8.7$ should be unlikely fits for tsunami events with only one observation of runup. Because the 1570, 1822, 1871b, and 1943 events only have localized recorded wave heights in the historical record (< 3 observations; although 1570 may be limited due to settlement history), any source model greater than $M_{w} 8.7$ seems unlikely. The earthquake source models assume "standard" large subduction zone earthquakes and do not account for more complex scenarios in smaller magnitude events that could potentially mimic locations of high runup (e.g. earthquakes with co-seismic submarine landslides, or "tsunami earthquakes;" Kanamori, 1972; Kanamori and Kikuchi, 1993; Papadopoulos and Kortekaas, 2003). Thus, analyses for the events with limited wave heights at few $(<3)$ regional tide gauges may not be reliable, especially if the $\mathrm{AIC}_{\mathrm{c}}$ analysis results in a solution $>\mathrm{M}_{\mathrm{w}} 8.7$.

\section{Why do smaller earthquake solutions fit well for 1960?}

The AIC analysis for the 1960 earthquake event shows that a $\mathrm{M}_{\mathrm{w}} 8.7$ source model is the best fit (32_87_1). This result disagrees with the literature, which interprets the 1960 earthquake as $\mathrm{M}_{\mathrm{w}} 9.5$ from instrumental records (Soloviev and Go., 1975; Dorn, 
1987). However, according to the RMSE of the 1960 tsunami simulations, the statistically significant $\mathrm{M}_{\mathrm{w}} 8.7$ source models do not best match the maximum wave heights recorded at all tide gauges on average. Instead, the $M_{w} 9.3$ and $M_{w} 9.5$ have the lowest RMSE values (Table 81960 RMSE), better agreeing with the literature.

Table 8: RMSE values of source models ranked as statistically significant from the AIC equations.

\begin{tabular}{|c|c|c|c|c|}
\hline Model & $\boldsymbol{\Delta}_{\mathbf{i}}$ & $\boldsymbol{\Delta}_{\mathbf{i}}$ Rank & RMSE (m) & $\begin{array}{c}\text { RMSE } \\
\text { Rank }\end{array}$ \\
\hline 39_93_1 & 0.31 & 5 & 2.54 & 1 \\
\hline 37_93_1 & 1.21 & 10 & 2.58 & 2 \\
\hline 40_93_1 & 2.32 & 17 & 2.63 & 3 \\
\hline 36_93_1 & 2.70 & 19 & 2.65 & 4 \\
\hline 40_93_2 & 2.80 & 21 & 2.65 & 5 \\
\hline 40_93_7 & 3.32 & 25 & 2.68 & 6 \\
\hline 39_93_7 & 3.87 & 32 & 2.70 & 7 \\
\hline 38_95_7 & 5.84 & 43 & 2.74 & 8 \\
\hline 38_95_3 & 5.94 & 44 & 2.75 & 9 \\
\hline 38_93_1 & 5.43 & 38 & 2.77 & 10 \\
\hline 40_93_8 & 5.48 & 39 & 2.77 & 11 \\
\hline 39_93_8 & 5.79 & 42 & 2.79 & 12 \\
\hline 40_93_9 & 6.18 & 46 & 2.81 & 13 \\
\hline 39_93_9 & 6.46 & 49 & 2.82 & 14 \\
\hline 38_93_7 & 6.47 & 50 & 2.82 & 15 \\
\hline 39_93_2 & 6.50 & 52 & 2.82 & 16 \\
\hline 38_93_9 & 6.71 & 53 & 2.83 & 17 \\
\hline 32_87_1 & 0.00 & 1 & 3.71 & 18 \\
\hline 39_87_3 & 0.15 & 2 & 3.72 & 19 \\
\hline 31_87_1 & 0.21 & 3 & 3.73 & 20 \\
\hline 33_87_1 & 0.30 & 4 & 3.73 & 21 \\
\hline 36_87_2 & 0.52 & 6 & 3.75 & 22 \\
\hline 40_87_3 & 0.77 & 7 & 3.76 & 23 \\
\hline 37_87_2 & 0.94 & 8 & 3.77 & 24 \\
\hline
\end{tabular}




\begin{tabular}{|c|c|c|c|c|}
\hline Model & $\boldsymbol{\Delta}_{\mathbf{i}}$ & $\boldsymbol{\Delta}_{\mathbf{i}}$ Rank & $\mathbf{R M S E}(\mathbf{m})$ & $\begin{array}{c}\text { RMSE } \\
\text { Rank }\end{array}$ \\
\hline 30_87_1 & 1.14 & 9 & 3.79 & 25 \\
\hline 34_87_1 & 1.41 & 11 & 3.80 & 26 \\
\hline 35_87_1 & 1.42 & 12 & 3.80 & 27 \\
\hline 28_87_1 & 1.48 & 13 & 3.81 & 28 \\
\hline 29_87_1 & 1.60 & 14 & 3.82 & 29 \\
\hline 27_87_1 & 1.82 & 15 & 3.83 & 30 \\
\hline 36_87_1 & 1.99 & 16 & 3.84 & 31 \\
\hline 34_87_2 & 2.56 & 18 & 3.88 & 32 \\
\hline 38_87_3 & 2.73 & 20 & 3.89 & 33 \\
\hline 36_87_3 & 2.85 & 22 & 3.90 & 34 \\
\hline 38_87_2 & 2.96 & 23 & 3.90 & 35 \\
\hline 39_87_2 & 3.21 & 24 & 3.92 & 36 \\
\hline 37_87_3 & 3.35 & 26 & 3.93 & 37 \\
\hline 35_87_3 & 3.38 & 27 & 3.93 & 38 \\
\hline 35_87_2 & 3.38 & 28 & 3.93 & 39 \\
\hline 25_87_1 & 3.54 & 29 & 3.94 & 40 \\
\hline 26_87_1 & 3.54 & 30 & 3.94 & 41 \\
\hline 41_87_3 & 3.57 & 31 & 3.94 & 42 \\
\hline 34_87_3 & 3.95 & 33 & 3.97 & 43 \\
\hline 40_87_2 & 4.05 & 34 & 3.97 & 44 \\
\hline 37_87_1 & 4.19 & 35 & 3.98 & 45 \\
\hline 33_87_2 & 4.37 & 36 & 4.00 & 46 \\
\hline 33_87_3 & 5.02 & 37 & 4.04 & 47 \\
\hline 42_87_3 & 5.51 & 40 & 4.07 & 48 \\
\hline 24_87_1 & 5.72 & 41 & 4.09 & 49 \\
\hline 38_87_1 & 6.01 & 45 & 4.11 & 50 \\
\hline 43_87_3 & 6.20 & 47 & 4.12 & 51 \\
\hline 32_87_2 & 6.42 & 48 & 4.13 & 52 \\
\hline 32_87_3 & 6.48 & 51 & 4.14 & 53 \\
\hline 23_87_1 & 6.72 & 54 & 4.16 & 54 \\
\hline 44_87_3 & 6.80 & 55 & 4.16 & 55 \\
\hline 31_87_2 & 6.87 & 56 & 4.17 & 56 \\
\hline 31_87_3 & 6.96 & 57 & 4.17 & 57 \\
\hline 41_87_2 & 6.97 & 58 & 4.17 & 58 \\
\hline & & & & \\
\hline
\end{tabular}


Conceptually, it is at first puzzling to see that the $\mathrm{AIC}_{\mathrm{c}}$ analysis selects some of the $M_{w} 8.7$ source models as more statistically significant than the $M_{w} 9.3$ and $M_{w} 9.5$ source models, despite the $M_{w} 8.7$ ruptures not being long enough along strike to match the entirety of observed wave heights in the historical record. However, these $M_{w} 8.7$ source models perform well in the AIC analysis because they overfit (i.e. fitting the bulk of the data more closely) the main concentration of historical wave height data between $38.5^{\circ} \mathrm{S}$ and $39.5^{\circ} \mathrm{S}$ (Figure 40). The rupture positions of the better-fitting $\mathrm{M}_{\mathrm{w}} 8.7$ events are nearly parallel along strike to the main concentration of historical data (Figure 40). This overfitting of the bulk of the observed data in the "significant" $\mathrm{M}_{\mathrm{w}} 8.7$ source models offset the underestimation of large observational wave heights at more distal tide gauges from the historical record that match more closely with the $M_{w} 9.3$ (and $M_{w}$ 9.5) source models (Figure 40). 


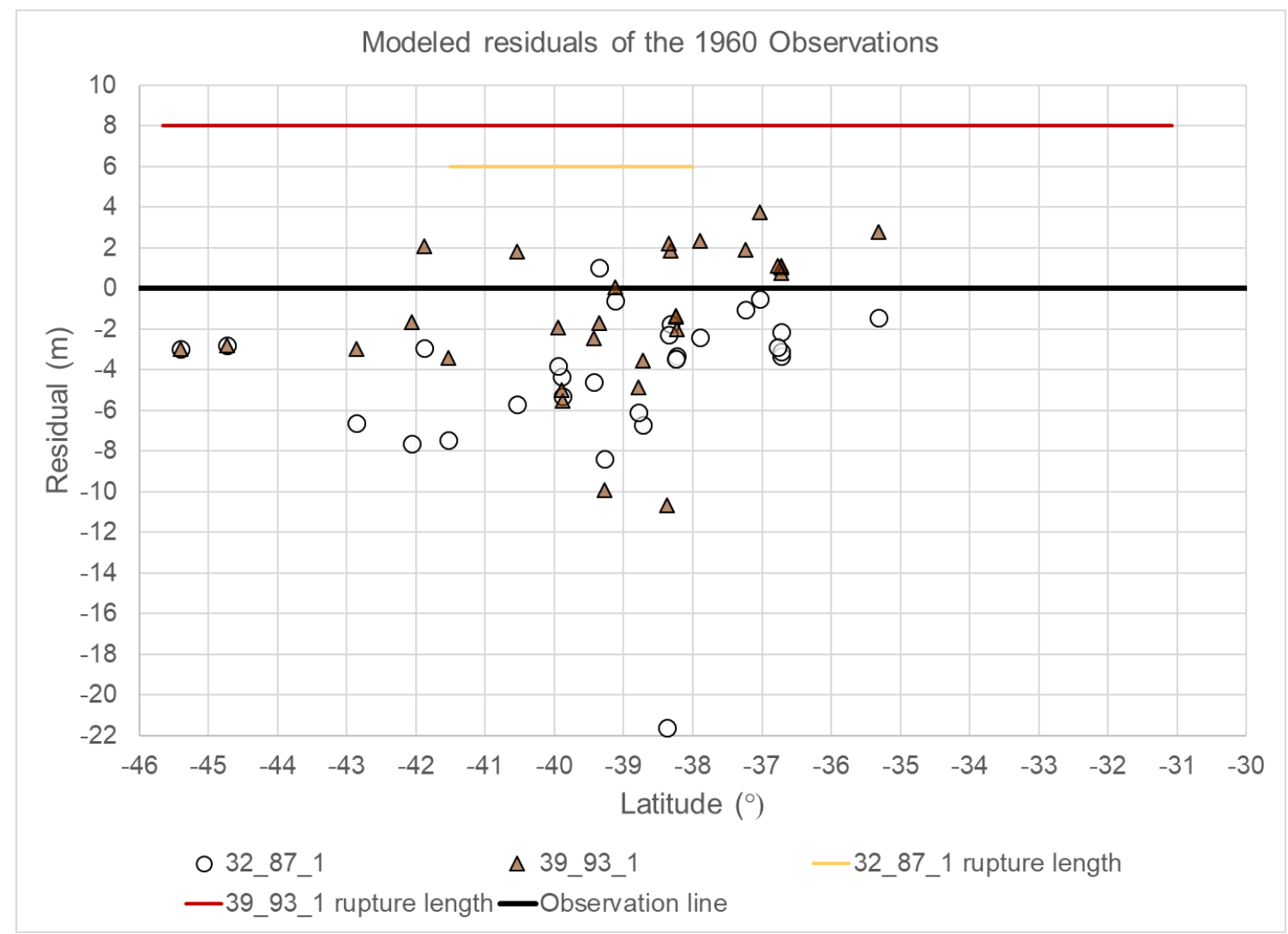

Figure 40: Residuals (simulated wave heights - observed wave heights) and rupture positions of two statistically significant earthquake source models for the 1960 event: 32_87_1 and 39_93_1. Calculated residual points closest to 0 indicate better agreement with the historical record; residual $>0$ overestimates the observed wave height while $<0$ underestimates the wave height.

The 1960 source model solutions support the interpretation that the $\mathrm{AIC}_{\mathrm{c}}$ analysis does not necessarily suggest a potential magnitude of an historical event, but rather propose where the main concentration of seafloor deformation occurred in the fault model. For example, the $M_{w} 9.3$ and $M_{w} 8.7$ earthquake source models that were deemed statistically significant fits by the AIC methods share a commonality, despite the large difference in rupture lengths. This commonality is that the region of maximum seafloor deformation occurred at $\sim 39^{\circ} \mathrm{S}$. The lack of consistent and evenly spaced wave height 
data along the coastline in the historical record within the area of study poses an uncertainty for identifying magnitudes, which was seen with the 1960 results. However, the $\mathrm{AIC}_{\mathrm{c}}$ analysis was able to suggest the area of where the majority of the seafloor deformation would have occurred to match the historical wave height data in lieu of overall rupture lengths. This outcome was supported with multiple historical events. For instance, the 1570, 1657, 1752, 1822, 1871, 1871b, 1906, 1920, 1928, and 1943 events are all examples where differently sized earthquakes shared a common region of high slip in spite of varying rupture lengths and positions along strike.

\section{The AIC range support the Mocha Fracture Zone hypothesis}

Previous studies have hypothesized that the buoyancy of subducting high oceanic features (like the MFZ) caused by crustal thickening and mantle serpentinization is the reason for the increase in normal stress at the subduction interface, which has a strong relation to earthquake rupture segmentation along the Chile-Peru margin (ContrerasReyes and Carrizo, 2011). However, other megathrust earthquake rupture propagations around the world, perhaps, cross segments that are similar to the MFZ in a subduction zone (Udias et al., 2012; Briggs et al., 2014). In this research, the smaller $M_{w} 8.7$ and $M_{w}$ 8.9 earthquake source models allow me to assess the hypothesis of whether the Mocha fracture zone (MFZ) acts as a boundary at $38.3^{\circ} \mathrm{S}$ between southern and northern ruptures. This is because the rupture lengths for these sized events are able to be bounded by the MFZ on one end of the rupture extent. Solutions that support the MFZ hypothesis 
must either correspond to a substantially significant rupture based on the AIC equations that was bounded by the MFZ, or had a high concentration of slip that taper to the MFZ.

The AIC overview graphs from Appendix E generally support the hypothesis that the MFZ controls earthquake rupture propagation and segmentation. The analyses of the $1575,1871 b, 1898,1906,1920$, and 1960 events show that the $M_{w} 8.7$ and $M_{w} 8.9$ earthquake source models are statistically significant on the southern side of the MFZ (i.e. south of central subfault \#38), but not on the northern side of the MFZ (Appendix E). On the other hand, the 1570,1657, 1730, 1751, 1822, 1835, 1871, and 1943 events show that $\mathrm{M}_{\mathrm{w}} 8.7$ and $\mathrm{M}_{\mathrm{w}} 8.9$ earthquake source models are statistically significant on the northern side of the MFZ, but not the southern side (Appendix E). With the exception of the 1927 event, which was not modeled accurately due to coarse bathymetry, only the 1837 and 1928 events have the potential to cross the MFZ. However, the 1837 analysis could be interpreted that ruptures on either side of the MFZ are better than ruptures that cross the MFZ (Appendix E). In the 1928 analysis, the "good-fitting" $\mathrm{M}_{\mathrm{w}} 8.7$ earthquake source models display an area of high slip on the northern segment, which then terminates to the south at approximately the MFZ. Since these statistically significant models that best match the nearshore tsunami historical data had a termination of slip at the MFZ, the two segments within the Chilean subduction zone may rupture independently.

In some cases, the hypothesis that the MFZ is a barrier to rupture also appears to be supported with the larger statistically significant "good-fitting" $M_{w} 9.1$ and $M_{w} 9.3$ 
earthquake source models. Despite the rupture of these higher magnitude models extending beyond the boundary of the MFZ, many of the statistically significant source models had evident tapering of slip occurring at the MFZ in some of the statistical analyses. For example, source model 38_91_3 within the 1570 statistical analysis had high slip on the southern segment near the MFZ that then tapers to the north. Source models 30_93_10 for the 1730 analysis and 51_89_2 for the 1928 analysis also depict this tapering at the MFZ, but from north to south. Although the tapering of slip that is present in these models is just a reflection of the stochastic slip models and not proof of the existence of the MFZ, the models that have this tapering appear to be better matches to the historical record than models that do not. Thus, the hypothesis of the MFZ has some validity based on the analysis of these events. However, to further assess the legitimacy of the proposed MFZ hypothesis, tsunami simulations derived from smaller earthquake source models $\left(\mathrm{M}_{\mathrm{w}} 8.0\right.$ to $\left.\mathrm{M}_{\mathrm{w}} 8.7\right)$ with additional variations of slip should be simulated to evaluate the historical earthquakes that appear to have high amounts of slip near the MFZ.

\section{Analys is of the 1960 event using high-resolution bathymetry}

The high resolution inundation maps generated at Tirúa, Quidico, and Puerto Saavedra were helpful to further refine the suite of best-fitting source models for the 1960 event. Out of the 33 earthquake source models that corresponded to a $\Delta_{\mathrm{i}}$ less than 4.0 from the $\mathrm{AIC}_{\mathrm{c}}$ analysis, two models, 40_93_7, and 39_93_7, matched the historic 
inundation dynamics at Tirúa, Quidico, and Puerto Saavedra. These models are similar, only offset by $23 \mathrm{~km}$ along strike, and show a high concentration of slip around $\sim 38.5^{\circ} \mathrm{S}$ to $40^{\circ} \mathrm{S}$, as do many other "good-fitting" $\mathrm{M}_{\mathrm{w}} 9.3$ and $\mathrm{M}_{\mathrm{w}} 8.7$ source models from the AIC analysis.

Despite the 40_93_7 and 39_93_7 earthquake source models not having the lowest $\Delta_{\mathrm{i}}$ values from the statistical analysis $\left(\Delta_{\mathrm{i}}\right.$ values between $\left.3.0-4.0\right)$, they did have low RMSE values ranked in the top eight for the 1960 analysis $(2.70-2.74 \mathrm{~m})$. Thus, earthquake source models 40_93_7 and 39_93_7 should be considered as part of the suite of most-likely slip scenarios for the 1960 event because of the high-resolution modeling results and RMSE values. A possible explanation for why these models did not yield the absolute lowest $\mathrm{AIC}_{\mathrm{c}}$ and $\Delta_{\mathrm{i}}$ values could be due to testing only a subset of the complete observation record. These solutions may only match the historic and geologic tsunami evidence the best at the three locations where higher resolution bathymetry is available, and not the other locations along the coast (main concentration of high slip for these models is adjacent to Puerto Saavedra; refer to Figure 38). Also, it is possible that this difference in the $\Delta_{\mathrm{i}}$ ranking is because the higher resolution and lower resolution source models are not simulated in the same model-space. If all source models were simulated with the high-resolution bathymetry, the AIC distribution may have varied.

When the AIC equations are calculated with just wave height data from Tirúa, Quidico, and Puerto Saavedra, earthquake source models 40_93_7 and 39_93_7 move up in the $\Delta_{\mathrm{i}}$ ranking from \#25 and \#32 to \#6 and \#4, respectively. Additionally, the RMSE of 
these earthquake source models were $1.07 \mathrm{~m}$ and $1.03 \mathrm{~m}$ when just comparing to the tide gauges at Tirúa, Quidico, and Puerto Saavedra. When evaluating just these tide gauges, models 40_93_9, 39_93_9, and 38_93_9 yielded the three lowest $\Delta_{\mathrm{i}}$ values and are the best fits, followed by 39_93_7 and then 40_93_7. However, when the all of the tide gauges are evaluated in the 1960 data set, models 40_93_9, 39_93_9, and 38_93_9 showed worse results with $\Delta_{\mathrm{i}}$ rankings of \#46, \#49, and \#50, respectively, and fall into the "considerably less substantial fit" category. Thus, despite models 40_93_9, 39_93_9, and 38_93_9 fitting Tirúa, Quidico, and Puerto Saavedra the best, they should not be considered in the statistical analysis, whereas 40_93_7 and 39_93_7 still should. Thus, using high-resolution bathymetry to match known inundation dynamics in the written record has demonstrated to be a useful tool to further refine "good-fitting" source models from the initial AIC model selection process with the lower resolution bathymetry.

\section{Model selection at Puerto Saave dra is the most constrained}

The high-resolution inundation maps allowed for testing model selection constraints at three sites (Tirúa, Quidico, and Puerto Saavedra). At Tirúa 16 out of the top 33 earthquake source models for the 1960 event generated a tsunami that matched estimated inundation dynamics, while 21 matched at Quidico and only 2 at Puerto Saavedra. Although many of the top 33 earthquake source models had solutions that inundated the correct areas at Puerto Saavedra, the majority did not have large enough wave heights at the village $(7-8 \mathrm{~m})$ and at the southern end of the bay $(11.5 \mathrm{~m})$. 
Therefore, Puerto Saavedra yielded the most constrained model selectivity of the three, followed by Tirúa and Quidico. This is partly because the bay of Puerto Saavedra is situated behind two large spits, and partly because of biases in the modeling dynamics. The inlet between the spits in front of Puerto Saavedra is narrow ( 170 m). GeoClaw does not account for erosional bathymetric/topographic change during simulations, thus the inlet cannot be widened by the tsunami. The 1960 tsunami most likely did widen the opening, although these kinds of details are not preserved in the written record. The two source models that matched inundation patterns in Puerto Saavedra (40_93_7 and 39_93_7) both had deep slip, which created 1 - $2 \mathrm{~m}$ of subsidence at the site, therefore artificially widening the inlet prior to tsunami inundation. Therefore, due to the geometry of this bay, results favor the selection of larger earthquake solutions with high, deep slip concentration near Puerto Saavedra that can induce land level changes.

Additionally, analyzing the total volume of displaced water also supports the conclusion that Puerto Saavedra requires precise seafloor deformation as opposed to solutions with broader regions of slip. The two best-fitting earthquake source models at Puerto Saavedra in the top 33 AIC analysis (40_93_7 and 39_93_7) had concentrated areas of highest slip compared to slightly broader slip along the fault plane in other $\mathrm{M}_{\mathrm{w}}$ 9.3 solutions, and therefore displaced a greater volume of water than the rest of the $\mathrm{M}_{\mathrm{w}}$ 9.3 earthquake solutions adjacent to Puerto Saavedra. This additional volume of displaced water in the source models 40_93_7 and 39_93_7 is also an important contributing factor in addition to the land-level change at Puerto Saavedra to help match 
observations there. Likewise, it should also be noted that the $M_{w} 9.5$ solutions of the sample slip model $\left(\Delta_{\mathrm{i}}<7\right)$ displaced even more water than the solutions from models 40_93_7 and 39_93_7, and also accurately inundated Puerto Saavedra.

\section{Similarities of the "Barrientos slip" to AIC selected models}

The "Barrientos slip" source model derived from the published earthquake slip solution by Barrientos and Ward (1990) did not produce a statistically significant solution for the 1960 event. However, their high concentration of slip at $\sim 39^{\circ} \mathrm{S}$ to $40^{\circ} \mathrm{S}$ is in the same location as the "good-fitting" earthquake source solutions from the AIC analyses, except deeper in the subduction zone (Figure 41). This general location of high slip at $39^{\circ} \mathrm{S}$ to $40^{\circ} \mathrm{S}$ also agrees with the published slip distribution by Moreno et al. (2009). The Barrientos and Ward (1990) earthquake slip solution was equivalent to a $\mathrm{M}_{\mathrm{w}} 9.3$ event and was derived from coastal land-level changes. However, because deeper portions of a subduction zone do not significantly contribute to tsunami generation (Geist, 2002), the tsunami simulated from the "Barrientos slip" solution was equivalent to a $\mathrm{M}_{\mathrm{w}} 9.0$, because slip that was too deep for this fault model was trimmed. Still the "Barrientos slip" solution had a main concentration of slip in the deepest part of the fault model, closest to land, suggesting smaller contribution to tsunami generation (Geist, 2002). This deeper slip suggested by Barrientos and Ward (1990) may be a product of simplified, planar fault geometry (Moreno et al., 2009). The total volume of displaced water from the "Barrientos slip" source model was not large enough to correctly inundate the three 
locations where high-resolution bathymetry was available (Tirúa, Quidico, and Puerto Saavedra). Similarly, the "Barrientos slip" source model displaced a lesser volume of water than all $M_{w} 9.3$ source models within my top $33 \Delta_{i}$ (refer to Figure 39). Therefore, the tsunami solution derived from the Barrientos and Ward (1990) earthquake source model was not large enough to match the tsunami record.

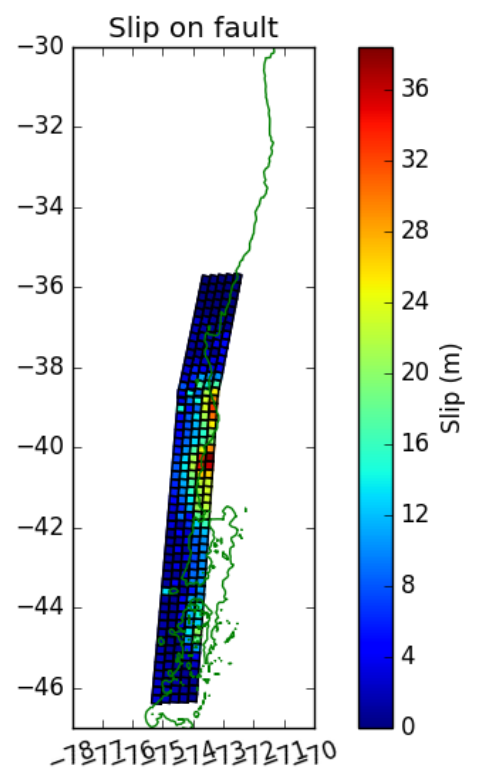

Figure 41: The $\mathrm{M}_{\mathrm{w}} 9.0$ earthquake source model based on land level changes from Barrientos and Ward (1990) 


\section{CHAPTER VII \\ SOURCES OF ERROR}

Each step within the methodology of this research involves uncertainties, which can lead to error within the modeled results. The following sections will explain implications of the assumptions and sources of error for all interpretations.

\section{The historic and geologic maximum wave height database}

The historical observation database only included the average maximum wave height value that occurred in a specific location. Only focusing on the maximum wave heights oversimplifies the complex inundation dynamics that actually occurred at a location. For example, in Penco and Valparaíso during the 1730 event, Carvajal et al. (2010) noted a range of water heights at different historical buildings. Similarly during the 1960 event, Maullín experienced a range of maximum wave heights across different parts of the estuary (Cisternas et al., 2005; Atwater et al., 2013). However, because the bathymetry used in this study is itself quite simplified (only 30" resolution), using an average singular maximum wave height to represent an entire location could allow the modeling space and results to be equally a generalization of wave dynamics. However, if the absolute overall maximum wave height was used for a larger simplified location, such as Maullín, instead of the average maximum wave height, the modeled results in the AIC analysis are expected to be typically underfit. Additionally, highest wave runup can reflect amplification from small-scale local bathymetric or topographic features or wave dynamics that are not accounted for using the coarse bathymetry available. 


\section{Subfault model}

The fault model had a consistent width rupture, independent of magnitude, from north to south for all simulated earthquakes. However, earthquakes are known to have variable rupture width along strike or with magnitude (Cande et al., 1987; Wang et al 2007). According to GPS data, the width of the Chilean seismogenic zone narrows to the south by $\sim 1^{\circ}$ in longitude, while retaining the same dipping angle (Wang et al., 2007). By not accounting for this narrowing and maintaining a constant width in the fault model for this research, the cosesimic slip on the southern segment within my earthquake source models may be smaller than what is realistic.

The dip values used for this fault model are derived from the USGS Slab 1.0 model; using slightly different depths and dip angles of subfaults would affect the tsunami simulations. For example, a more shallowly dipping fault model would widen the wavelength of a tsunami and result in less seafloor deformation for the same amount of slip. Vice-versa, a steeper dipping fault model would lead to shorter wavelengths and an increase in maximum wave heights in the near-field (Melnick et al., 2012). However, all tsunami simulations are exposed to the same kind of error associated with the fault model. Thus, I assume that this fault model error has a lesser impact in the overall variation of results. 


\section{Numerical modeling}

The primary sources of error associated with the numerical modeling methods can be categorized into 1) bathymetry and topography or 2) mathematical approximations in GeoClaw. Errors regarding the coarseness of the 30 arc-second bathymetric resolution has been previously discussed in the Methodology chapter. In addition, because the 30 arc-second GEBCO bathymetry and topography focuses on the deep ocean, the quality of coverage on the shallow shelf is highly variable (Intergovernmental Oceanographic Commission, 2014). The potential lack of detailed bathymetry can cause many aspects of waveform propagation, such as wave diffraction, refraction, resonance, and shoaling, to be less accurate in shallow water regions. Because these kinds of propagation properties play a significant role in affecting overall wave heights and wave velocities (Pan et al., 2010), high resolution bathymetry ( $1 / 3$ arc-second) is necessary to model coastal inundation (MacInnes et al., 2013). If more high-resolution bathymetry grids were used at different locations along the coast, inundation characteristics would be better assessed when comparing to historic tsunami events. Having higher resolution bathymetry could eliminate a greater number of earthquake source models from being a "good-fit," in the AIC analyses.

An additional bathymetric/topographic issue in this study was the lack of accounting for bathymetric/topographic changes throughout the historical record between 1570 and 1960 (except for removing a post-1960 bridge in the high-resolution topography for Tirúa). Some of these bathymetric and topographic differences that 
change over time include beach progradation, estuary filling, spit-growth, and relative sea-level rise. A specific tsunami waveform that may have been able to inundate a certain area in 1570 may not be able to inundate that same area in the present because of these dynamic coastal processes. By not using historic coastlines when modeling maximum wave heights at each tide gauge, there is uncertainty regarding the accuracy of the "goodfitting" source models for historical earthquakes.

Within the category of mathematical approximations in GeoClaw, there are many complex processes that are numerically simplified when simulating a tsunami. For instance, the steps from converting slip on the fault model from seafloor deformation to sea-surface deformation and the generation of a tsunami are overgeneralized when compared to reality (Tanioka and Satake, 1996). GeoClaw converts slip to seafloor deformation with the Okada (1985) equations and approximations. These equations and approximations assume a two-dimensional flat seafloor made up of homogeneous elastic material for each subfault within the fault model, which is used to calculate only the vertical component of slip, assuming an instantaneous rupture. However, in real life examples, megathrust earthquake ruptures are three-dimensional and tend to propagate slip in all directions along the fault plane, releasing most of the energy over a 90 -second period (Yamazaki, and Cheung, 2011). Seafloor deformation occurring on a steep slope with large horizontal displacement relative to vertical displacement is also an important contribution to sea-surface deformation and tsunami generation (Tanioka and Satake, 1996). The simplifications regarding the role of rise time, rupture velocity, and horizontal 
motion within the GeoClaw application are an inherent source of error that affect the timing of tsunami generation, and therefore wave propagation, and maximum runup (Fuentes et al., 2018).

\section{Validation of models (through AIC)}

There are a considerable amount of uncertainties within the AIC statistical analysis in terms of selecting a "good-fitting" approximating model (Burnham and Anderson, 2003). Through the mathematical equations, by definition, one earthquake source model will automatically be considered the "best-fitting model" (with a $\Delta_{\mathrm{i}} 0$ ) relative to the others. Despite this selection, the "best-fitting model" may not be best when evaluated in context. For example, in the 1960 analysis, a $M_{w} 8.7$ earthquake source model was chosen by the AIC analysis as "best-fitting", yet it was instrumentally recorded that the 1960 event was a $\mathrm{M}_{\mathrm{w}} 9.5$ event. Knowing the context of the historical rupture, such as extent of destruction and damages, should be used as a qualitative validity check. Thus, understanding the data set prior to the analysis will help identify any biases within the model selection process, like the results of the 1960 analysis. Once a biased source model is established as a "good-fitting" model, other analyses, such as the method used in this research of evaluating the root mean square error (RMSE), can help in explaining the initial selection process. Also, examining the data before the formal AIC analysis allows for the detection of obvious outliers and outright errors (Burnham and Anderson, 2003). Burnham and Anderson (2003) claim that the model selection 
within AIC has a tendency to select models that are too simple (underfitted). This claim is seen in many of my results, especially the 1960 event where the $M_{w} 8.7$ earthquake source models appeared significant. To deal with this bias, one method is to examine the residuals from the modeled and observed data to potentially uncover any patterns in the candidate models during the selection process.

There are additional computer-intensive resampling methods that may improve the AIC assessment, such as the bootstrap method (a type of Monte Carlo method; Efron, 1979; Efron and Tibshirani, 1993; Mooney and Duval, 1993). A major purpose of the bootstrap method deals with robust estimation of sampling variances (standard errors) and confidence intervals in model selection applications (Burnham and Anderson, 2003). To limit model selection uncertainty, 1,000 bootstrap samples may be needed, which would consist of systematically removing different tide gauge data points to estimate confidence intervals, sampling variances (or standard errors), and potentially single out any data point outliers (Burnham and Anderson, 2003). Also 10,000 earthquake source models for the model selection may be needed to limit selection uncertainty (Burnham and Anderson, 2003). 


\section{CHAPTER VII}

\section{SUMMARY AND CONCLUSIONS}

The purpose of this research was to define a new methodology to characterize the unknown rupture parameters of known pre-instrumental earthquakes. If successful, this methodology can be implemented for all subduction zones with either a geologic and/or historical record. South-central Chile was an excellent candidate for this research because of its well documented tsunami record. Portions of south-central Chile have been inundated by destructive tsunamis from at least 17 near-field sources between 1570 and 1960. These earthquakes have been documented at localized regions within the historical record and through limited paleotsunami studies. Thus, the rupture dynamics of these preinstrumental earthquakes are not well constrained and pose a major problem in terms of reliable forecasting. To improve tsunami forecasting in the future, it is crucial to understand how the Chilean subduction zone behaved during these 17 earthquake events.

To define the historical earthquake rupture parameters of south-central Chile, I forward modeled tsunami simulations from 423 different ruptures source models. These source models ranged from $\mathrm{M}_{\mathrm{w}} 8.7$ to $\mathrm{M}_{\mathrm{w}} 9.5$ and had stochastic slip distributions. I evaluated the validity of these tsunami simulations by comparing the maximum wave heights at 47 strategically placed tide gauges along the coast to the recorded wave heights from each tsunami event from historical record and tsunami field observations. Through this analysis, my goal was to suggest a suite of possible earthquake rupture scenarios that 
may have been similar to each past event in the Chilean historical record. The following summarizes the key results and interpretations of each earthquake:

\section{0 earthquake}

- Four "substantial fit" source models that range from $\mathrm{M}_{\mathrm{w}} 8.7$ to $\mathrm{M}_{\mathrm{w}} 9.1$ and rupture the northern segment of the fault model.

- High slip located at $\sim 36^{\circ} \mathrm{S}$ and/or $\sim 40^{\circ} \mathrm{S}\left(\mathrm{M}_{\mathrm{w}} 8.7\right.$ solutions had high slip only at $\left.\sim 37.5^{\circ} \mathrm{S}\right)$.

- Supports Mocha fracture zone (MFZ) segmentation; northern rupture if smaller earthquake, both southern and northern ruptures if larger earthquake.

\section{5 earthquake}

- Two $\mathrm{M}_{\mathrm{w}} 9.3$ "substantial fit" source models that ruptured the deepest portion of the fault model at $\sim 39^{\circ} \mathrm{S}$.

- Supports MFZ segmentation; southern rupture.

\section{7 earthquake}

- All 423 models calculate as being statistically significant, so conclusions below are not robust.

- Eleven "substantially fitting" models consisting of $M_{w} 8.7$ (one), $M_{w} 9.3$ (nine), and $\mathrm{M}_{\mathrm{w}} 9.5$ (one). 
- Larger "substantially fitting" models $\left(\mathrm{M}_{\mathrm{w}} 9.3\right.$ and $\left.\mathrm{M}_{\mathrm{w}} 9.5\right)$ most likely a result from a few observations of high wave heights

- Smaller "substantially fitting" source model $\left(\mathrm{M}_{\mathrm{w}} 8.7\right)$ most likely a result of limited observations in the historical record in 1657.

- Supports MFZ segmentation; northern rupture.

1730 earthquake

- Five statistically significant $\mathrm{M}_{\mathrm{w}} 9.3$ (four) to $\mathrm{M}_{\mathrm{w}} 9.5$ (one) source models with one $\mathrm{M}_{\mathrm{w}} 9.3$ "substantial fit" better than the rest.

- High slip located at $\sim 34^{\circ} \mathrm{S}$.

- Supports MFZ segmentation; northern rupture.

\section{1 earthquake}

- Ten "substantially fitting" models consisting of $\mathrm{M}_{\mathrm{w}} 8.7$ (seven), $\mathrm{M}_{\mathrm{w}} 8.9$ (one) and $\mathrm{M}_{\mathrm{w}} 9.3$ (one).

- High slip of $\mathrm{M}_{\mathrm{w}} 8.7$ and 8.9 at $\sim 35^{\circ} \mathrm{S}$ and $\sim 37{ }^{\circ} \mathrm{S}$, while high slip for $\mathrm{M}_{\mathrm{w}} 9.3$ at $40^{\circ} \mathrm{S}$ to $\sim 43^{\circ} \mathrm{S}$.

- Supports MFZ segmentation; could be northern or southern rupture.

\section{2 earthquake}

- Four "substantial fit" source models that range from $M_{w} 8.7$ to $M_{w} 8.9$.

- High shallow slip at $\sim 34^{\circ} \mathrm{S}$ to $\sim 35^{\circ} \mathrm{S}\left(\mathrm{M}_{\mathrm{w}} 8.7\right)$ or high deep slip at $\sim 37^{\circ} \mathrm{S}\left(\mathrm{M}_{\mathrm{w}}\right.$ 8.9).

- Supports MFZ segmentation; northern rupture. 


\section{5 earthquake}

- Two $\mathrm{M}_{\mathrm{w}} 8.7$ "substantial fit" source models with high slip at $\sim 36.5^{\circ} \mathrm{S}$.

- RMSE analysis suggests that two "considerably less significant" $\mathrm{M}_{\mathrm{w}} 9.3$ solutions and one "considerably less significant" $\mathrm{M}_{\mathrm{w}} 9.5$ solution match mean maximum wave heights for all gauges better than the selected "substantial fit" solutions.

- The larger "considerably less significant" solutions rupture the deeper portion of the southern segment within the fault model between $\sim 39^{\circ} \mathrm{S}$ to $\sim 44^{\circ} \mathrm{S}$.

- Supports MFZ segmentation; northern rupture if smaller; southern if larger.

\section{7 earthquake}

- $\quad 15 \mathrm{M}_{\mathrm{w}} 8.7$ "substantial fit" source models that ruptured on the northern segment of the fault model.

- Nine other less statistically significant source models that ruptured on the southern segment of the fault model.

- Rupture may cross MFZ segmentation or ruptures on either side of the MFZ are better fits than ruptures that cross the MFZ.

\section{1 earthquake}

- Five $\mathrm{M}_{\mathrm{w}} 8.7$ "substantial fit" source models with high slip either deep or shallow at $\sim 35.5{ }^{\circ} \mathrm{S}$.

- Supports MFZ segmentation; northern rupture

1871 b earthquake 
- Three "substantially fitting" models, $\mathrm{M}_{\mathrm{w}} 9.1$ (one) and $\mathrm{M}_{\mathrm{w}} 9.3$ (two), in addition to some smaller statistically significant $\mathrm{Mw} 8.7$ source models

- High slip at $\sim 40^{\circ} \mathrm{S}$ or $\sim 34^{\circ} \mathrm{S}$ for the $\mathrm{M}_{\mathrm{w}} 9.3$ models, $40^{\circ} \mathrm{S}$ and $36^{\circ} \mathrm{S}$ for the $\mathrm{M}_{\mathrm{w}}$ 9.1 model, and $\sim 44^{\circ} \mathrm{S}$ for the smaller $\mathrm{M}_{\mathrm{w}} 8.7$ models

- Larger "substantially fitting" models $\left(\mathrm{M}_{\mathrm{w}}\right.$ 9.3) most-likely a result from a high localized observed wave height

- $\mathrm{M}_{\mathrm{w}} 8.7$ are more plausible due to lack of observations in the historical record.

- Supports MFZ segmentation; northern if small, either northern or southern if larger earthquake.

1898 earthquake

- 15 statistically significant $\mathrm{M}_{\mathrm{w}} 8.7$ (nine) to $\mathrm{M}_{\mathrm{w}} 8.9$ ( (six) source models with one $\mathrm{M}_{\mathrm{w}} 8.7$ "substantial fit" better than the rest.

- High slip on the shallow portion of the fault model between $\sim 42.5^{\circ} \mathrm{S}$ and $\sim 43.5^{\circ} \mathrm{S}$.

- Supports MFZ segmentation; southern rupture.

\section{6 earthquake}

- 68 "substantially fitting" models consisting of $\mathrm{M}_{\mathrm{w}} 8.7$ (58) and $\mathrm{M}_{\mathrm{w}} 8.9$ (ten) that ruptured on the south-central segment of the fault model.

- Majority had high slip near the MFZ at $\sim 39^{\circ} \mathrm{S}$.

- Supports MFZ segmentation; southern rupture.

1920 earthquake 
- Three $\mathrm{M}_{\mathrm{w}} 8.7$ "substantial fit" source models with high slip between $\sim 40^{\circ} \mathrm{S}$ and $\sim 41^{\circ} \mathrm{S}$.

- Supports MFZ segmentation; southern rupture.

1927 earthquake

- All earthquake source models had approximately the same $\Delta_{\mathrm{i}}$ value.

- Bathymetry was too coarse for water to inundate tide gauges at Puerto Asyen and Puerto Cisnes (located within fjords $\sim 140 \mathrm{~km}$ from the open ocean).

- Insufficient model results.

1928 earthquake

- Four "substantially fitting" models consisting of $\mathrm{M}_{\mathrm{w}} 8.7$ (three rupturing on northern segment) and $\mathrm{M}_{\mathrm{w}} 8.9$ (one rupturing on southern segment).

- High slip in both the north and south at $\sim 38^{\circ} \mathrm{S}$ to $\sim 38.5^{\circ} \mathrm{S}$ and $\sim 42^{\circ} \mathrm{S}$, respectively.

- Rupture may cross MFZ segmentation.

1943 earthquake

- Three "substantially fitting" models consisting of $\mathrm{M}_{\mathrm{w}} 8.7$ (one) and $\mathrm{M}_{\mathrm{w}} 8.9$ (two) with high slip between $\sim 40^{\circ} \mathrm{S}$ and $\sim 41^{\circ} \mathrm{S}$ in the deeper portion of the fault model.

- Supports MFZ segmentation; southern rupture.

1960 earthquake

- 16 "substantially fitting" source models consisting of $M_{w} 8.7$ (14) and $M_{w} 9.3$ (two). 
- High slip at $\sim 39^{\circ} \mathrm{S} . \mathrm{M}_{\mathrm{w}} 9.3$ solutions also had shallow high slip in the north or south at either $\sim 33^{\circ} \mathrm{S}$ or $\sim 41^{\circ} \mathrm{S}$.

- RMSE analysis and high-resolution bathymetric inundation at Tirúa, Quidico, and Puerto Saavedra support that the larger $M_{w} 9.3$ solutions are better fits than the smaller $\mathrm{M}_{\mathrm{w}} 8.7$ solutions.

- Published slip model "Barrientos slip" derived from Barrientos and Ward (1990) was not statistically significant, however had similar location of high slip at $\sim 39^{\circ} \mathrm{S}$ to $40^{\circ} \mathrm{S}$ (except in the deepest portion of the fault model). The slip distribution published by Moreno et al. (2009) agrees with high shallow slip at $\sim 39^{\circ} \mathrm{S}$ to $40^{\circ} \mathrm{S}$.

- Supports MFZ segmentation; southern rupture.

Through using the AIC statistical application, it appears that variable slip patterns play a crucial part in matching good-fitting rupture models. All earthquake statistical analyses suggest that significant source-models are derived from the models with variable slip rather than uniform slip. Often times, the uniform slip models yielded $\Delta_{\mathrm{i}}$ values amongst the worst of all earthquake source model solutions. This supports the widespread understanding that earthquakes do not rupture uniformly along strike (Mikumo and Miyatake, 1978; Mai and Beroza, 2002; Moreno et al., 2010; Wang et al., 2013). Future modeling applications should not use uniform slip solutions when assessing potential rupture parameters. 
Similarly, the location of high sea surface deformation in the slip distribution is also a critical parameter for model selection, rather than overall magnitude. This is seen in the 1960 statistical analysis where the AIC application showed that $\mathrm{M}_{\mathrm{w}} 8.7$ source models were just as significant at $\mathrm{M}_{\mathrm{w}} 9.3$ source models. This result is due to an uneven distribution of sampling along strike, thus signifying the importance of additional geologic studies where possible. The currently available tsunami historic record is unevenly distributed and concentrated in the major populated areas. In terms of the 1960 statistical analysis, the "good-fitting" $\mathrm{M}_{\mathrm{w}} 8.7$ earthquake source models appeared to match the bulk of the recorded wave heights in a specific area where there were many spatially-close observations, but underestimated the recorded maximum wave heights. This differs from the $M_{w} 9.3$ statistically significant earthquake source models that matched the maximum recorded wave height extents better, but overestimated the bulk of the recorded wave heights in the regions with a high concentration of placed tide gauges. However, the commonality between these statistically significant models of different sizes is the location of the concentration of maximum slip in each respective fault model.

The $1 / 3$ arc-second high-resolution bathymetry was a helpful tool to further analyze some of the statistically significant source models and as an overall check of the AIC application. By having previous knowledge of the inundation dynamics that occurred at specific locations during the 1960 tsunami (e.g. Tirúa, Quidicio, and Puerto Saavedra), I was able to pinpoint a rupture along strike, specific magnitude, and slip distribution within the top $\Delta_{\mathrm{i}}$ models that best match the known inundation dynamics at 
these three sites. According to the models, the source model that best matched the inundation dynamics for where we had data (Tirúa, Quidico, and Puerto Saavedra) were models 40_93_7, and 39_93_7 (offset by $23 \mathrm{~km}$ along strike).

Using the known inundation dynamics for further model selection refinement also allowed me to hypothesize which locations have greater model selection constraints to different modeling inputs. For example, Tirúa appears to have more model selection constraints than Quidico as 16 of the top $33 \Delta_{\mathrm{i}}$ source models for the 1960 analysis correctly inundated Tirúa, while 22 source models correctly inundated Quidico. Additionally, Puerto Saavedra may have the most constrained model selectivity as 40_93_7, and 39_93_7 were the only two out of the top 33 source models for the 1960 analysis that correctly matched inundation. However, the few correct matches at Puerto Saavedra is more likely the result of the geomorphology around Puerto Saavedra limiting inundation in GeoClaw; the code does not change the bathymetry due to erosion from the tsunami. Puerto Saavedra is situated behind two spits with a narrow inlet to a bay that most likely widened during the 1960 tsunami. Therefore, favorable source models at Puerto Saavedra required high deep slip to create subsidence and artificially widen the inlet to allow for full tsunami inundation. Earthquake source models 40_93_7 and 39_93_7 both had a slip distribution pattern (relating to seafloor deformation) that caused land level change to generate enough water to inundate this coastal site.

Supplementary evaluations of validity, like inundation matching with highresolution bathymetry, is useful in refining potential suites of best-fitting solutions, 
especially when the overall bathymetry used in the tsunami simulations is too coarse to be considered useful for modeling inundation dynamics (e.g. 30 arc-second resolution). Other useful evaluations of validity include root mean square error (RMSE) analysis. RMSE evaluates the mean differences in wave heights at all tide gauges for a given earthquake source model. In almost all cases, the model with the best $\Delta_{\mathrm{i}}$ value also had the lowest RMSE value.

This research provides a new methodology, which applies tsunami modeling in regions with a long historical record and paleotsunami histories, to learn about past earthquake rupture characteristics and tsunami behavior. The tsunami historical record is a valid dataset for revealing suites of most-likely earthquake parameters, such as region of high slip and potential magnitudes for these pre-instrumental earthquakes. Therefore, this methodology can be applied to better understand rupture dynamics of other subduction zones as well.

\section{Future Research}

Future studies in south-central Chile should prioritize finding new geologic tsunami evidence to allow for a more even distribution of sampling for tsunami modeling comparisons. Additionally, using far-field deposits (e.g. Japan) may also be helpful to refine the rupture characteristics of a given earthquake. For example, the far-field tsunami records may eliminate the $M_{w} 8.7$ earthquake source solutions as "good-fitting" scenarios 
for the 1960 event as they probably are not large enough to displace enough water to correctly inundate Japan.

From a modeling standpoint, more models with additional stochastic slip distributions should be simulated to increase the model selection space. The validity of the AIC statistical analysis is correlative to the number of models inputted into the analysis (Burnham and Anderson, 2003) and will be improved with more models. However, assessments should not solely rely on the outputs from the AIC application. Additional methods like simulating the inundation dynamics at more locations with high-resolution bathymetry (e.g. Maullín) will be useful in assessing the validity of the AIC statistical analyses. It should likewise be prioritized to simulate smaller earthquake source models $\left(\mathrm{M}_{\mathrm{w}} 8.7\right.$ and smaller). Assessing the slip distributions of these shorter rupture events will be required to assess some of the smaller historical earthquakes in this study with magnitude estimations less than M 8.7. By analyzing smaller source models, a greater understanding regarding the important question of segmentation at the Mocha fracture zone is also possible. Simulating more earthquake source models will ultimately allow for greater insight in relation to the spatial variability of locking zones through time and provide clues to the recurrence of locations with high slip. 


\section{REFERENCES}

Akaike, H., 1974, A new look at the statistical model identification: Institute of Electrical and Electronic Engineers, Transactions on Automatic Control, Vol. 19 No. 6, p. 716-723.

Anderson, D.R., Burnham, K.P., and Thompson, W.L., 2000, Null hypothesis testing: problems, prevalence, and an alternative: Journal of Wildlife Management 64, p. 912-923.

Angermann, D., Klotz, J., \& Reigber, C., 1999, Space-geodetic estimation of the NazcaSouth America Euler vector: Earth and Planetary Science Letters, Vol. 171, No. 3, p. 329-334.

Atwater, B. F., 1999, Surviving a tsunami--lessons from Chile, Hawaii, and Japan (No. 1187): Geological Survey (USGS).

Atwater, B. F., Cisternas, M., Yulianto, E., Prendergast, A. L., Jankaew, K., Eipert, A. A., Starin-Fernando, W.I., Tejakusuma, I., Schiappacasse, I., \& Sawai, Y., 2013, The 1960 tsunami on beach-ridge plains near Maullín, Chile: Landward descent, renewed breaches, aggraded fans, multiple predecessors: Andean Geology, Vol. 40, No. 3, p. 393-418.

Atwater, B. F., Musumi-Rokkaku, S., Satake, K., Tsuji, Y., Ueda, K., \& Yamaguchi, D. K., 2016, The orphan tsunami of 1700: Japanese clues to a parent earthquake in North America: University of Washington Press, p. 144.

Barrientos, S. E., \& Ward, S. N., 1990, The 1960 Chile earthquake: inversion for slip distribution from surface deformation: Geophysical Journal International, Vol. 103, No.3, p. 589-598.

Becerra, R., 2018, Assessing the use of tsunami simulations as a tool to predict source magnitudes and locations of paleoearthquakes in chile, [Master's thesis]: Central Washington University, p. 130. 
Berger, M. J., \& LeVeque, R. J., 1998, Adaptive mesh refinement using wavepropagation algorithms for hyperbolic systems: SIAM Journal on Numerical Analysis, Vol. 35, No. 6, p. 2298-2316.

Berger, M. J., D. L. George, R. J. LeVeque, and K. T. Mandli, 2011, The GeoClaw software for depth-averaged flows with adaptive refinement, Adv: Water Resour. Vol. 34, p. 1195-1206.

Berninghausen, W. H., 1962, Tsunamis reported from the west coast of South America 1562-1960: Bulletin of the Seismological Society of America, Vol. 52, No.4, p. 915-921.

Borrero, J.C., LeVeque R.J., Greer, S.D., O’Neill, S., and Davis, B.N., 2015, Observations and modelling of tsunami currents at the port of Tauranga, New Zealand: Australasian Coasts and Ports Conference 2015: 22 ${ }^{\text {nd }}$ Australasian Coastal and Engineering Conference and the $15^{\text {th }}$ Australasian Port and Harbour Conference, p. 90.

Breiman, L., 2001, Statistical modeling: the two cultures (with discussion): Statistical Science, Vol. 16, p. 199-231.

Briggs, R. W., Engelhart, S. E., Nelson, A. R., Dura, T., Kemp, A. C., Haeussler, P. J., Corbett, D.R., Angster, S.J., \& Bradley, L. A., 2014, Uplift and subsidence reveal a nonpersistent megathrust rupture boundary (Sitkinak Island, Alaska): Geophysical Research Letters, Vol. 41, No. 7, p. 2289-2296.

Brill, D., Brückner, H., Jankaew, K., Kelletat, D., Scheffers, A., \& Scheffers, S., 2011, Potential predecessors of the 2004 Indian Ocean Tsunami-Sedimentary evidence of extreme wave events at Ban Bang Sak, SW Thailand: Sedimentary Geology, Vol. 239, No. 3-4, p. 146-161.

Burgos, R. U., 1990, La rebelión indígena de 1712: los tributarios de Chiloé contra la encomienda. Tiempo y espacio, (1), 73-86.Urbina Carrasco, M. X., 2014, El frustrado fuerte de Tenquehuén en el archipiélago de los Chonos, 1750: dimensión chilota de un conflicto hispano-británico: Historia (Santiago), Vol. 47, No. 1, p. 133-155. 
Burnham, K. P., \& Anderson, D. R., 2002, Model selection and multimodel inference 2nd ed.: A practical information-theoretic approach: New York, NY, Springerverlag New York pp. 488.

Campos-Harriet, F., 1989, Historia de Concepción 1550-1988: Editorial Universitaria, Santiago, pp. 438.

Cande, S. C., Leslie, R. B., Parra, J. C., \& Hobart, M., 1987, Interaction between the Chile Ridge and Chile Trench: geophysical and geothermal evidence: Journal of Geophysical Research: Solid Earth, Vol. 92, No. B1, p. 495-520.

Carvajal, M., Cisternas, M., \& Catalán, P. A., 2017, Source of the 1730 Chilean earthquake from historical records: Implications for the future tsunami hazard on the coast of Metropolitan Chile: Journal of Geophysical Research: Solid Earth, Vol. 122, No.5, p. 3648-3660.

Cisternas, M., Atwater, B.F., Torrejón, F., Sawai, Y., Machuca, G., Lagos, M., Eipert, A., Youlton, C., Salgado, I., Kamataki, T., Shishikura, M., Rajendran, C.P., Malik, J.K., Rizal, Y., and Husni, M., 2005, Predecessors of the giant 1960 Chile earthquake: Nature, Vol. 437, p. 404-407.

Cisternas, M., Torrejón, F., \& Gorigoitía, N., 2012, Amending and complicating Chile's seismic catalog with the Santiago earthquake of 7 August 1580: Journal of South American Earth Sciences, Vol. 33, No. 1, p. 102-109.

Cisternas, M., Garrett, E., Wesson, R., Dura, T., \& Ely, L. L., 2017, Unusual geologic evidence of coeval seismic shaking and tsunamis shows variability in earthquake size and recurrence in the area of the giant 1960 Chile earthquake: Marine Geology, Vol. 385, p. 101-113.

Clawpack Development Team, 2017, Clawpack Version 5.4.1: http://www.clawpack.org (assessed 2018), doi:10.5281/zenodo.262111.

Collier, S., \& Sater, W. F., 1996, A history of Chile, 1808-1994: Cambridge Latin American Studies, Vol. 82, Cambridge, New York, University Press. 
Comte, D., \& Suárez, G., 1994, An inverted double seismic zone in Chile: Evidence of phase transformation in the subducted slab: Science, Vol. 263 No. 5144, p. $212-$ 215.

Contreras-Reyes, E., Grevemeyer, I., Flueh, E. R., \& Reichert, C., 2008, Upper lithospheric structure of the subduction zone offshore of southern Arauco peninsula, Chile, at 38 S: Journal of Geophysical Research: Solid Earth, Vol. 113, No. B07303.

Contreras-Reyes, E., \& Carrizo, D., 2011, Control of high oceanic features and subduction channel on earthquake ruptures along the Chile-Peru subduction zone: Physics of the Earth and Planetary Interiors, Vol. 186, No. 1-2, p. 49-58.

Davidson, C. 1936. Great Earthquakes: T. Hurby and Co.: Myrby, London pp. 286.

Di Giacomo, D., I. Bondár, D.A. Storchak, E.R. Engdahl, P. Bormann and J. Harris, 2015a, ISC-GEM: Global Instrumental Earthquake Catalogue (1900-2009): III. Re-computed MS and mb, proxy MW, final magnitude composition and completeness assessment: Phys. Earth Planet. Int., Vol. 239, p. 33-47.

Di Giacomo, D., E.R. Engdahl and D.A. Storchak, 2018, The ISC-GEM Earthquake Catalogue (1904-2014): status after the Extension Project: Earth System Science Data, Vol. 10, p. 1877-1899.

Dura, T., Horton, B. P., Cisternas, M., Ely, L. L., Hong, I., Nelson, A. R., Wesson, R.L., Pilarczyk, J.E., Parnell, A.C., \& Nikitina, D., 2017, Subduction zone slip variability during the last millennium, south-central Chile: Quaternary Science Reviews, Vol. 175, p. 112-137.

Efron, B., 1979, Computers and the theory of statistics: thinking the unthinkable: Society for Industrial and Applied Mathematics review, Vol. 21, No. 4, p. 460-480.

Efron, B. and Tibshirani, R.J., 1993, An Introduction to the Bootstrap: Monographs on Statistics and Applied Probability, Vol. 57, Chapman \& Hall, New York, New York, pp. 456. 
Ely, L. L., Cisternas, M., Wesson, R. L., \& Dura, T., 2014, Five centuries of tsunamis and land-level changes in the overlapping rupture area of the 1960 and 2010 Chilean earthquakes: Geology, Vol. 42, No. 11, p. 995-998.

FitzRoy, R., 1839, Narrative of the Surveying Voyages of His Majesty's Ships Adventure and Beagle, between the Years 1826 and 1836: Describing Their Examination of the Southern Shores of South America, and the Beagle's Circumnavigation of the Globe, Vol. 2: Proceedings of the Second Expedition, 1831-1836, under the Command of Captain Robert FitzRoy, R.N., with Appendix, London: Henry Colbum, Great Marlborough Street, pp. 693.

Fritz, H.M., Petroff, C.M., Catalán, P.A., Cienfuegos, R., Winckler, P., Kalligeris, N., Weiss, R., Barrientos, S.E., Meneses, G., Valderas-Bermejo, C., Ebeling, C., Papadopoulos, A., Contreras, M., Almar, R., Dominguez, J.C., and Synolakis, C.E., 2011, Field Survey of the 27 February 2010 Chile Tsunami: Pure and Applied Geophysics, Vol. 168, p. 1989-2010.

Fuentes, M., Riquelme, S., Ruiz, J., \& Campos, J., 2018, Implications on 1+ 1 D Tsunami runup modeling due to time features of the earthquake source: Pure and Applied Geophysics, Vol. 175, No.4, p. 1393-1404.

Fujiwara, O., Masuda, F., Sakai, T., Irizuki, T., Fuse, K., Daiyoni, K., 1999, Holocene tsunami deposits detected by drilling in drowned valleys of Boso and Miura peninsulas: Quaternary Research, Vol. 38, p. 41-58.

Garrett, E., Shennan, I., Woodroffe, S. A., Cisternas, M., Hocking, E. P., \& Gulliver, P., 2015, Reconstructing paleoseismic deformation, 2: 1000 years of great earthquakes at Chucalén, south central Chile: Quaternary Science Reviews, Vol. 113, p. 112-122.

Geist, E.L., 2002, Complex earthquake rupture and local tsunamis: Journal of Geophysical Research, Vol. 107, p. 1-6.

George, D. L., \& LeVeque, R. J., 2006, Finite volume methods and adaptive refinement for global tsunami propagation and local inundation. Science of Tsunami Hazards, Vol. 24, No.5, p. 319-328, 2006. 
Gonzalez, F., R. J. LeVeque, P. Chamberlain, B. Hirai, J. Varkovitzky, and D.L. George, 2011, GeoClaw Results for the NTHMP Tsunami Benchmark Problems, [NTHMP] National Tsunami Hazard Mitigation Program: Proceedings and Results of the 2011 NTHMP Model Benchmarking Workshop, Boulder: U.S. Department of Commerce/NOAA/NTHMP (NOAA Special Report), pp. 436.

Guarda, G, 1978, Historia urbana del Reino de Chile: Editorial Andrés Bello, Santiago, Chile, pp. 509.

Gusiakov, V. K., 2007, Tsunami as a destructive aftermath of oceanic impacts: In Comet/asteroid impacts and human society, Springer, Berlin, Heidelberg, p. $247-263$.

Gusman, A. R., Tanioka, Y., MacInnes, B. T., \& Tsushima, H., 2014, A methodology for near-field tsunami inundation forecasting: Application to the 2011 Tohoku tsunami: Journal of Geophysical Research: Solid Earth, Vol. 119, No. 11, p. 81868206.

Haberland, C., Rietbrock, A., Lange, D., Bataille, K., \& Dahm, T., 2009, Structure of the seismogenic zone of the southcentral Chilean margin revealed by local earthquake traveltime tomography: Journal of Geophysical Research: Solid Earth, Vol. 114, No. B01317.

Hayes, G. P., Wald, D. J., \& Johnson, R. L., 2012, Slab1.0: A three-dimensional model of global subduction zone geometries: Journal of Geophysical Research: Solid Earth, Vol. 117, No. B01302.

Hirata, K., Geist, E., Satake, K., Tanioka, Y., \& Yamaki, S., 2003, Slip distribution of the 1952 Tokachi-Oki earthquake (M 8.1) along the Kuril trench deduced from tsunami waveform inversion: Journal of Geophysical Research: Solid Earth, Vol. 108, No. 101029/2002JB001976.

Hong, I., Dura, T., Ely, L. L., Horton, B. P., Nelson, A. R., Cisternas, M., Nikitina, D., \& Wesson, R. L., 2017, A 600-year-long stratigraphic record of tsunamis in southcentral Chile: The Holocene, Vol. 27, No. 1, p. 39-51. 
Iida, K., Cox, D. C., \& Pararas-Carayannis, G., 1967, Preliminary catalog of tsunamis occurring in the Pacific Ocean: Data Repository, Vol 5, No. HIG-67-10, Hawaii Institute of Geophysics, University of Hawaii, Honolulu, pp. 131.

Iida, K., 1984, Catalog of tsunamis in Japan and its neighboring countries: Department of Civil Engineering, Aichi Institute of Technology, Special Report, Japan pp. 52.

Instituto Hidrográfico de la Armada, 1982, Atlas Hidrográfico de Chile: Derrotero de la Costa de Chile Volumen III, El Instituto, Mapoteca/SHOA, Valparaiso, Chile.

Intergovernmental Oceanographic Commission, 2014, The GEBCO_2014 Grid: International Hydrographic Organization and Intergovernmental Oceanic Commission of UNESCO, [Accessed: 2014].

Jara-Munoz, J., Melnick, D., Brill, D., \& Strecker, M. R., 2015, Segmentation of the 2010 Maule Chile earthquake rupture from a joint analysis of uplifted marine terraces and seismic-cycle deformation patterns: Quaternary Science Reviews, Vol. 113, p. 171-192.

Kanamori, H, 1972, Mechanism of tsunami earthquakes: Physics of the earth and planetary interiors, Vol. 6, No. 5, p. 346-359.

Kanamori, H., 1977, The energy release in great earthquakes: Journal of geophysical research, Vol. 82, No. 20, p. 2981-2987.

Kanamori, H., \& Kikuchi, M, 1993, The 1992 Nicaragua earthquake: a slow tsunami earthquake associated with subducted sediments: Nature, Vol. 361, No. 6414, p. 714.

Kempf, P., Moernaut, J., Van Daele, M., Vandoorne, W., Pino, M., Urrutia, R., \& De Batist, M., 2017, Coastal lake sediments reveal 5500 years of tsunami history in south central Chile: Quaternary Science Reviews, Vol. 161, p. 99-116.

Kullback, S., 1959, Information theory and statistics: John Wiley and Sons, New York, New York. 
Lagos, M., 2000, Near-source-generated tsunamis at the coasts of Chile (Tsunamis de origen cercano a las costas de Chile), Revista de Geografia Norte Grande, Vol. 27, p. 93-102.

Lander, J. F., \& Lockridge, P. A., 1989, United States Tsunamis (including United States Possessions): 1690-1988: US Department of Commerce, National Oceanic and Atmospheric Administration, National Environmental Satellite, Data, and Information Service, National Geophysical Data Center, Vol 41, No. 2, Boulder, Colorado.

Lane, K. E., \& Levine, R. M., 2015, Pillaging the Empire: Piracy in the Americas, 15001750: Routledge, p. 88-92.

Leonard, L. J., Currie, C. A., Mazzotti, S., \& Hyndman, R. D., 2010, Rupture area and displacement of past Cascadia great earthquakes from coastal coseismic subsidence: Bulletin, Vol. 122, No. 11-12, p. 2079-2096.

LeVeque, R. J., 2002, Finite volume methods for hyperbolic problems, Vol. 31, Cambridge university press, pp 558.

LeVeque, R. J., George, D. L., \& Berger, M. J., 2011, Tsunami modelling with adaptively refined finite volume methods: Acta Numerica, Vol. 20, p. 211-289.

Lockridge, P. A., 1985, Tsunamis in Peru-Chile, Report SE-39: World Data Center for Solid Earth Geophysics, Boulder, CO, pp. 97.

Lomnitz, C., 2004, Major earthquakes of Chile: a historical survey, 15351960: Seismological Research Letters, Vol. 75, No., 3, 368-378.

MacInnes, B. T., Weiss, R., Bourgeois, J., \& Pinegina, T. K., 2010, Slip distribution of the 1952 Kamchatka great earthquake based on near-field tsunami deposits and historical records: Bulletin of the Seismological Society of America, Vol. 100, No. 4, p. 1695-1709. 
MacInnes, B. T., Gusman, A. R., LeVeque, R. J., \& Tanioka, Y., 2013, Comparison of earthquake source models for the 2011 Tohoku event using tsunami simulations and near-field observations: Bulletin of the Seismological Society of America, Vol. 103, No. 2B, p. 1256-1274.

Mai, P. M., \& Beroza, G. C., 2002, A spatial random field model to characterize complexity in earthquake slip: Journal of Geophysical Research: Solid Earth, Vol. 107, No. B11, 2308, ESE-10, p. 1-27.

Matos-Llavona, P., Ely L.L., MacInnes, B., Dura, T., Cisternas, M., Tang, H., Dolcimascolo, A., Bruce, D., 2019, Mapping and reconstructing the paleostunami record in a new site in Queule, South-central Chile, Geological Society of America Abstracts with Programs. Vol. 41, No. 4, p. 28.

Melnick, D., Bookhagen, B., Strecker, M. R., \& Echtler, H. P., 2009, Segmentation of megathrust rupture zones from fore-arc deformation patterns over hundreds to millions of years, Arauco peninsula, Chile: Journal of Geophysical Research: Solid Earth, Vol. 114, No. B01407.

Melnick, D., Moreno, M., Motagh, M., Cisternas, M., \& Wesson, R. L., 2012, Splay fault slip during the Mw 8.82010 Maule Chile earthquake: Geology, Vol 40, No.3, p. 251-254.

Mikumo, T., \& Miyatake, T., 1978, Dynamical rupture process on a three-dimensional fault with non-uniform frictions and near-field seismic waves: Geophysical Journal International, Vol. 54, No. 2, p. 417-438.

Milne, J., 1900a, Discussion of the preceding registers, Seismological investigations: Fourth report CSI, p. 161-238: Report 69 $9^{\text {th }}$ Meeting. British Association for the Advancement of Science, held at Dover in 1899, p. 203.

Milne, J., 1911. Catalogue of destructive earthquakes: Report of the 81st meeting of the British Association for the Advancement of Science, Portsmouth, London, United Kingdom, p. 649-740.

Monge, J., 1993, Estudios de riesgo de tsunami en costas chilenas: Santiago, Chile. Jornadas chilenas de Sismología en ingeniería antisísmica, Vol. 2, p. 3-22. 
Mooney, C. Z., Duval, R. D., \& Duvall, R., 1993, Bootstrapping: A nonparametric approach to statistical inference: Sage Publications, No. 95, Newbury Park, California.

Moreno, M. S., Bolte, J., Klotz, J., \& Melnick, D., 2009, Impact of megathrust geometry on inversion of coseismic slip from geodetic data: Application to the 1960 Chile earthquake: Geophysical Research Letters, Vol. 36, No. L16310, doi: 10.1029/2009GL039276.

Moreno, M., Rosenau, M., \& Oncken, O., 2010, 2010 Maule earthquake slip correlates with pre-seismic locking of Andean subduction zone: Nature, Vol. 467, No. 7312, p. 198.

Morton, R. A., Gelfenbaum, G., \& Jaffe, B. E., 2007, Physical criteria for distinguishing sandy tsunami and storm deposits using modern examples: Sedimentary Geology, Vol. 200, No. 3-4, p. 184-207.

Nanayama, F., Satake, K., Furukawa, R., Shimokawa, K., Atwater, B. F., Shigeno, K., \& Yamaki, S., 2003, Unusually large earthquakes inferred from tsunami deposits along the Kuril trench: Nature, Vol. 424, No. 6949, p. 660.

National Geophysical Data Center / World Data Service (NGDC/WDS), 2018, Global Historical Tsunami Database: National Geophysical Data Center, NOAA, doi:10.7289/V 5PN93H7 [Accessed: 2018].

Nelson, A. R., Briggs, R. W., Dura, T., Engelhart, S. E., Gelfenbaum, G., Bradley, L. A., Forman, S.L., Vane, C.H., \& Kelley, K. A., 2015, Tsunami recurrence in the eastern Alaska-Aleutian arc: A Holocene stratigraphic record from Chirikof Island, Alaska: Geosphere, Vol. 11, No. 4, p. 1172-1203.

Okada, Y., 1985, Surface deformation due to shear and tensile faults in a halfspace: Bulletin of the seismological society of America, Vol. 75, No. 4, p. 11351154.

Okal, E. A., 2009, Excitation of tsunamis by earthquakes, in The Sea: Tsunamis E. N. Bernard and A. R. Robinson (Editors), Harvard University Press, Cambridge, Massachusetts, Vol. 15, p. 137-177. 
Pan, W., Wang, S. A., \& Cai, S., 2010, Numerical simulations of the coastal effects of tsunami waves caused by the 1993 Hokkaido-Nansei-Oki earthquake: Chinese Journal of Oceanology and Limnology, Vol. 28, No. 5, p. 1029-1039.

Papadopoulos, G. A., \& Kortekaas, S., 2003, Characteristics of landslide generated tsunamis from observational data: In Submarine Mass Movements and Their Consequences, Springer, Dordrecht. p. 367-374.

Peterson, C.D., Carver, G.A., Cruikshank, K.M., Abramson, H.F., Garrison-Laney, C.E., Dengler, L.A., 2011, Evaluation of the use of paleotsunami deposits to reconstruct inundation distance and runup heights associated with prehistoric inundation events, Crescent City, southern Cascadia margin: Earth Surface Processes and Landforms, Vol. 36, p. 967-980.

Pinegina, T. K., \& Bourgeois, J., 2001, Historical and paleo-tsunami deposits on Kamchatka, Russia: long-term chronologies and long-distance correlations: Natural Hazards and Earth System Sciences, Vol. 1, No. 4, p. 177185 .

Rodríguez, J. A. S., 2006, La defensa hispana del Reino de Chile: Tiempo y espacio, No. 16. SSN 0716-9671.

Saint-Amand, P., 1963, Special issue: Oceanographic, geologic, and engineering studies of the Chilean earthquakes of May 1960: Seismological Society of America Bulletin, Vol. 53, No. 6, Special issue, p. 1123-1436.

Satake, K., Wang, K., \& Atwater, B. F., 2003, Fault slip and seismic moment of the 1700 Cascadia earthquake inferred from Japanese tsunami descriptions: Journal of Geophysical Research: Solid Earth, Vol. 108, No. 2545.

Satake, K., \& Atwater, B. F., 2007, Long-term perspectives on giant earthquakes and tsunamis at subduction zones: Annual. Reviews of Earth and Planetary Sciences, Vol. 35, p. 349-374.

Satake, K., F. Nanayama, and S. Yamaki, 2008, Fault models of unusual tsunamis in the 17th century: Earth Planets Space, Vol. 60, p. 925-935. 
Saavedra Villegas, R, 1984, Panorama histórico de Tomé. Siglos XVI a XIX: Antecedentes geográficos y miscelánea communal: Ediciones Perpelén, pp. 69.

Scheffers, A., Kelletat, D., Vött, A., May, S. M., \& Scheffers, S., 2008, Late Holocene tsunami traces on the western and southern coastlines of the Peloponnesus (Greece): Earth and Planetary Science Letters, Vol. 269, No. 1-2, p. 271-279.

Sievers, H., Villegas, G., \& Barros, G, 1963, The seismic sea wave of 22 May 1960 along the Chilean Coast: Seismological Society of America, Bulletin, Vol. 53, p. 11251190 .

Soloviev, S. L., and Go, C. N., 1975, A Catalogue of Tsunamis on the Eastern Shore of the Pacific Ocean [Dates Include 1513-1968]. Moscow: Academy of Sciences of the USSR, Nauka Publishing House, pp. 204. (Canadian Translation of Fisheries and Aquatic Sciences No. 5078, 1984).

Tang, L., Titov, V.V., and Chamberlin, C.D., 2009, Development, testing, and applications of site-specific tsunami inundation models for real-time forecasting: Journal of Geophysical Research, Vol. 114, p. 1-22.

Tanioka, Y., \& Satake, K., 1996, Tsunami generation by horizontal displacement of ocean bottom: Geophysical Research Letters, Vol. 23, No. 8, p. 861-864.

Udías, A., Madariaga, R., Buforn, E., Muñoz, D., \& Ros, M., 2012, The large Chilean historical earthquakes of 1647, 1657, 1730, and 1751 from contemporary documents: Bulletin of the Seismological Society of America, Vol. 102, No. 4, p. 1639-1653.

Urbina Carrasco, M.X., 2014, El frustrado fuerte de Tenquehuén en el archipiélago de los Chonos, 1750: dimensión chilota de un conflicto hispano-británico. Historia (Santiago), Vol. 47, No. 1, p. 133-155.

Urbina Carrasco, M. X., Abbott, N. G., \& Vega, M. C., 2016, Aportes a la historia sísmica de Chile: el caso del gran terremoto de 1730: Anuario de Estudios Americanos, Vol. 73, No. 2, p. 657-687. 
Valenzuela, J., 2012, Relaciones jesuitas del terremoto de 1730: Santiago, Valparaíso y Concepción: Cuadernos de Historia, Vol. 37, Santiago, p. 195-224.

Van Dorn, W. G., 1987, Tide gage response to tsunamis. Part II: Other oceans and smaller seas: Journal of physical oceanography, Vol. 17, No. 9, p. 1507-1516.

Villanueva, A. S., Sánchez, J. B., \& Rubio, C. Q., 2010, Flandes Indiano Chiloense: un patrimonio invencible en el tiempo: Revista de Urbanismo, No. 23, pp. 27.

Wang, K., Hu, Y., Bevis, M., Kendrick, E., Smalley Jr, R., Vargas, R. B., \& Lauría, E., 2007, Crustal motion in the zone of the 1960 Chile earthquake: Detangling earthquake-cycle deformation and forearc-sliver translation: Geochemistry, Geophysics, Geosystems, Vol. 8, No. 10.

Weischet, W., 1963, Further observations of geologic and geomorphic changes resulting from the catastrophic earthquake of May 1960, in Chile: Bulletin of the Seismological Society of America, Vol. 53, No. 6, p. 1237-1257.

Yamazaki, Y., Cheung, K. F., \& Kowalik, Z., 2011, Depth-integrated, non-hydrostatic model with grid nesting for tsunami generation, propagation, and run-up: International Journal for Numerical Methods in Fluids, Vol. 67, No. 12, p. 20812107 


\section{APPENDICES}

\section{APPENDIX A}

\section{Fault model}

Table A1: Fault model template used to create earthquake source models. Row 1 at depth A corresponds to the southwest corner of the fault model. Stochastic variable slip distributions were inputted into the "slip" column to generate each individual source model.

\begin{tabular}{|c|c|c|c|c|c|c|c|c|c|c|}
\hline Row & Depth & $\begin{array}{c}\text { Longitude } \\
\left({ }^{\circ} \mathbf{S}\right)\end{array}$ & $\begin{array}{c}\text { Latitude } \\
\left({ }^{\circ} \mathbf{W}\right)\end{array}$ & $\begin{array}{c}\text { Depth } \\
\mathbf{2}\end{array}$ & Dip & Strike & Rake & Length & Width & Slip \\
\hline 1 & A & 75.35808 & 46.28350 & 6.00 & 6 & 4.68 & 90 & 23 & 23 & \\
\hline 1 & B & 75.05473 & 46.25957 & 8.40 & 10 & 4.68 & 90 & 23 & 23 & \\
\hline 1 & C & 74.75450 & 46.24952 & 12.40 & 14 & 4.68 & 90 & 23 & 23 & \\
\hline 1 & D & 74.45740 & 46.25334 & 17.96 & 18 & 4.68 & 90 & 23 & 23 & \\
\hline 1 & E & 74.15421 & 46.22942 & 25.07 & 22 & 4.68 & 90 & 23 & 23 & \\
\hline 2 & A & 75.32980 & 46.06232 & 6.00 & 6 & 4.68 & 90 & 23 & 23 & \\
\hline 2 & B & 75.03371 & 46.06614 & 8.40 & 10 & 4.68 & 90 & 23 & 23 & \\
\hline 2 & C & 74.73154 & 46.04221 & 12.40 & 14 & 4.68 & 90 & 23 & 23 & \\
\hline 2 & D & 74.43555 & 46.04603 & 17.96 & 18 & 4.68 & 90 & 23 & 23 & \\
\hline 2 & E & 74.13655 & 46.03598 & 25.07 & 22 & 4.68 & 90 & 23 & 23 & \\
\hline 3 & A & 75.30775 & 45.86888 & 6.00 & 6 & 4.68 & 90 & 23 & 23 & \\
\hline 3 & B & 75.00665 & 45.84495 & 8.40 & 10 & 4.68 & 90 & 23 & 23 & \\
\hline 3 & C & 74.70866 & 45.83490 & 12.40 & 14 & 4.68 & 90 & 23 & 23 & \\
\hline 3 & D & 74.41377 & 45.83872 & 17.96 & 18 & 4.68 & 90 & 23 & 23 & \\
\hline 3 & E & 74.11588 & 45.82867 & 25.07 & 22 & 4.68 & 90 & 23 & 23 & \\
\hline 4 & A & 75.28273 & 45.66157 & 6.00 & 6 & 4.68 & 90 & 23 & 23 & \\
\hline 4 & B & 74.98579 & 45.65152 & 8.40 & 10 & 4.68 & 90 & 23 & 23 & \\
\hline 4 & C & 74.68585 & 45.62759 & 12.40 & 14 & 4.68 & 90 & 23 & 23 & \\
\hline 4 & D & 74.39205 & 45.63141 & 17.96 & 18 & 4.68 & 90 & 23 & 23 & \\
\hline 4 & E & 74.09526 & 45.62136 & 25.07 & 22 & 4.68 & 90 & 23 & 23 & \\
\hline 5 & A & 75.25781 & 45.45426 & 6.00 & 6 & 4.68 & 90 & 23 & 23 & \\
\hline 5 & B & 74.95893 & 45.43033 & 8.40 & 10 & 4.68 & 90 & 23 & 23 & \\
\hline 5 & C & 74.66615 & 45.43416 & 12.40 & 14 & 4.68 & 90 & 23 & 23 & \\
\hline 5 & D & 74.36736 & 45.41023 & 17.96 & 18 & 4.68 & 90 & 23 & 23 & \\
\hline 5 & E & 74.07469 & 45.41405 & 25.07 & 22 & 4.68 & 90 & 23 & 23 & \\
\hline 6 & A & 75.23299 & 45.24695 & 6.00 & 6 & 4.68 & 90 & 23 & 23 & \\
\hline 6 & B & 74.93519 & 45.22302 & 8.40 & 10 & 4.68 & 90 & 23 & 23 & \\
\hline
\end{tabular}




\begin{tabular}{|c|c|c|c|c|c|c|c|c|c|c|}
\hline Row & Depth & $\begin{array}{c}\text { Longitude } \\
\left({ }^{\circ} \mathrm{S}\right)\end{array}$ & $\begin{array}{c}\text { Latitude } \\
\left({ }^{\circ} \mathbf{W}\right)\end{array}$ & $\begin{array}{c}\text { Depth } \\
2\end{array}$ & Dip & Strike & Rake & Length & Width & Slip \\
\hline 6 & $\mathrm{C}$ & 74.64348 & 45.22685 & 12.40 & 14 & 4.68 & 90 & 23 & 23 & \\
\hline 6 & $\mathrm{D}$ & 74.34880 & 45.21679 & 17.96 & 18 & 4.68 & 90 & 23 & 23 & \\
\hline 6 & $\mathrm{E}$ & 74.05417 & 45.20674 & 25.07 & 22 & 4.68 & 90 & 23 & 23 & \\
\hline 7 & A & 75.20827 & 45.03964 & 6.00 & 6 & 4.68 & 90 & 23 & 23 & \\
\hline 7 & $\mathrm{~B}$ & 74.91455 & 45.02959 & 8.40 & 10 & 4.68 & 90 & 23 & 23 & \\
\hline 7 & $\mathrm{C}$ & 74.61788 & 45.00566 & 12.40 & 14 & 4.68 & 90 & 23 & 23 & \\
\hline 7 & $\mathrm{D}$ & 74.32726 & 45.00948 & 17.96 & 18 & 4.68 & 90 & 23 & 23 & \\
\hline 7 & $\mathrm{E}$ & 74.03370 & 44.99943 & 25.07 & 22 & 4.68 & 90 & 23 & 23 & \\
\hline 8 & A & 75.18364 & 44.83233 & 6.00 & 6 & 4.68 & 90 & 23 & 23 & \\
\hline 8 & B & 74.89097 & 44.82228 & 8.40 & 10 & 4.68 & 90 & 23 & 23 & \\
\hline 8 & $\mathrm{C}$ & 74.59836 & 44.81223 & 12.40 & 14 & 4.68 & 90 & 23 & 23 & \\
\hline 8 & $\mathrm{D}$ & 74.30579 & 44.80217 & 17.96 & 18 & 4.68 & 90 & 23 & 23 & \\
\hline 8 & $\mathrm{E}$ & 74.01028 & 44.77825 & 25.07 & 22 & 4.68 & 90 & 23 & 23 & \\
\hline 9 & A & 75.15910 & 44.62502 & 6.00 & 6 & 4.68 & 90 & 23 & 23 & \\
\hline 9 & B & 74.86450 & 44.60109 & 8.40 & 10 & 4.68 & 90 & 23 & 23 & \\
\hline 9 & $\mathrm{C}$ & 74.57590 & 44.60492 & 12.40 & 14 & 4.68 & 90 & 23 & 23 & \\
\hline 9 & $\mathrm{D}$ & 74.28438 & 44.59486 & 17.96 & 18 & 4.68 & 90 & 23 & 23 & \\
\hline 9 & $\mathrm{E}$ & 73.98992 & 44.57094 & 25.07 & 22 & 4.68 & 90 & 23 & 23 & \\
\hline 10 & A & 75.13466 & 44.41771 & 6.00 & 6 & 4.68 & 90 & 23 & 23 & \\
\hline 10 & B & 74.84407 & 44.40766 & 8.40 & 10 & 4.68 & 90 & 23 & 23 & \\
\hline 10 & $\mathrm{C}$ & 74.55352 & 44.39761 & 12.40 & 14 & 4.68 & 90 & 23 & 23 & \\
\hline 10 & $\mathrm{D}$ & 74.26005 & 44.37368 & 17.96 & 18 & 4.68 & 90 & 23 & 23 & \\
\hline 10 & $E$ & 73.97258 & 44.37750 & 25.07 & 22 & 4.68 & 90 & 23 & 23 & \\
\hline 11 & A & 75.10735 & 44.19653 & 6.00 & 6 & 4.68 & 90 & 23 & 23 & \\
\hline 11 & B & 74.82074 & 44.20035 & 8.40 & 10 & 4.68 & 90 & 23 & 23 & \\
\hline 11 & $\mathrm{C}$ & 74.53121 & 44.19030 & 12.40 & 14 & 4.68 & 90 & 23 & 23 & \\
\hline 11 & $\mathrm{D}$ & 74.23877 & 44.16637 & 17.96 & 18 & 4.68 & 90 & 23 & 23 & \\
\hline 11 & $E$ & 73.95230 & 44.17019 & 25.07 & 22 & 4.68 & 90 & 23 & 23 & \\
\hline 12 & $\mathrm{~A}$ & 75.08605 & 44.00309 & 6.00 & 6 & 4.68 & 90 & 23 & 23 & \\
\hline 12 & B & 74.79748 & 43.99304 & 8.40 & 10 & 4.68 & 90 & 23 & 23 & \\
\hline 12 & $\mathrm{C}$ & 74.50896 & 43.98299 & 12.40 & 14 & 4.68 & 90 & 23 & 23 & \\
\hline 12 & $\mathrm{D}$ & 74.21754 & 43.95906 & 17.96 & 18 & 4.68 & 90 & 23 & 23 & \\
\hline 12 & $\mathrm{E}$ & 73.93207 & 43.96288 & 25.07 & 22 & 4.68 & 90 & 23 & 23 & \\
\hline 13 & $\bar{A}$ & 75.05894 & 43.78191 & 6.00 & 6 & 4.68 & 90 & 23 & 23 & \\
\hline 13 & B & 74.77431 & 43.78573 & 8.40 & 10 & 4.68 & 90 & 23 & 23 & \\
\hline 13 & $\mathrm{C}$ & 74.48385 & 43.76180 & 12.40 & 14 & 4.68 & 90 & 23 & 23 & \\
\hline
\end{tabular}




\begin{tabular}{|c|c|c|c|c|c|c|c|c|c|c|}
\hline Row & Depth & $\begin{array}{c}\text { Longitude } \\
\left({ }^{\circ} \mathbf{S}\right)\end{array}$ & $\begin{array}{c}\text { Latitude } \\
\left({ }^{\circ} \mathbf{W}\right)\end{array}$ & $\begin{array}{c}\text { Depth } \\
2 \\
\end{array}$ & Dip & Strike & Rake & Length & Width & Slip \\
\hline 13 & $\mathrm{D}$ & 74.19931 & 43.76562 & 17.96 & 18 & 4.68 & 90 & 23 & 23 & \\
\hline 13 & $\mathrm{E}$ & 75.03487 & 43.57460 & 25.07 & 22 & 4.68 & 90 & 23 & 23 & \\
\hline 14 & A & 74.75122 & 43.57842 & 6.00 & 6 & 4.68 & 90 & 23 & 23 & \\
\hline 14 & B & 74.46468 & 43.56837 & 8.40 & 10 & 4.68 & 90 & 23 & 23 & \\
\hline 14 & $\mathrm{C}$ & 74.17819 & 43.55831 & 12.40 & 14 & 4.68 & 90 & 23 & 23 & \\
\hline 14 & $\mathrm{D}$ & 73.90895 & 43.74170 & 17.96 & 18 & 4.68 & 90 & 23 & 23 & \\
\hline 14 & $\mathrm{E}$ & 73.89175 & 43.54826 & 25.07 & 22 & 4.68 & 90 & 23 & 23 & \\
\hline 15 & A & 75.01381 & 43.38116 & 6.00 & 6 & 4.68 & 90 & 23 & 23 & \\
\hline 15 & B & 74.44264 & 43.36106 & 8.40 & 10 & 4.68 & 90 & 23 & 23 & \\
\hline 15 & $\mathrm{C}$ & 74.72528 & 43.35723 & 12.40 & 14 & 4.68 & 90 & 23 & 23 & \\
\hline 15 & $\mathrm{D}$ & 74.15713 & 43.35100 & 17.96 & 18 & 4.68 & 90 & 23 & 23 & \\
\hline 15 & $\mathrm{E}$ & 73.87166 & 43.34095 & 25.07 & 22 & 4.68 & 90 & 23 & 23 & \\
\hline 16 & A & 74.98991 & 43.17385 & 6.00 & 6 & 4.68 & 90 & 23 & 23 & \\
\hline 16 & B & 74.70527 & 43.16380 & 8.40 & 10 & 4.68 & 90 & 23 & 23 & \\
\hline 16 & $\mathrm{C}$ & 74.42067 & 43.15375 & 12.40 & 14 & 4.68 & 90 & 23 & 23 & \\
\hline 16 & $\mathrm{D}$ & 74.13612 & 43.14369 & 17.96 & 18 & 4.68 & 90 & 23 & 23 & \\
\hline 16 & $\mathrm{E}$ & 73.85162 & 43.13364 & 25.07 & 22 & 4.68 & 90 & 23 & 23 & \\
\hline 17 & A & 74.96609 & 42.96654 & 6.00 & 6 & 4.68 & 90 & 23 & 23 & \\
\hline 17 & B & 74.39876 & 42.94644 & 8.40 & 10 & 4.68 & 90 & 23 & 23 & \\
\hline 17 & $\mathrm{C}$ & 74.67950 & 42.94261 & 12.40 & 14 & 4.68 & 90 & 23 & 23 & \\
\hline 17 & $\mathrm{D}$ & 74.11517 & 42.93638 & 17.96 & 18 & 4.68 & 90 & 23 & 23 & \\
\hline 17 & $\mathrm{E}$ & 73.82872 & 42.91246 & 25.07 & 22 & 4.68 & 90 & 23 & 23 & \\
\hline 18 & A & 74.94236 & 42.75923 & 6.00 & 6 & 4.68 & 90 & 23 & 23 & \\
\hline 18 & B & 74.65962 & 42.74918 & 8.40 & 10 & 4.68 & 90 & 23 & 23 & \\
\hline 18 & $\mathrm{C}$ & 74.37692 & 42.73913 & 12.40 & 14 & 4.68 & 90 & 23 & 23 & \\
\hline 18 & $\mathrm{D}$ & 74.09427 & 42.72907 & 17.96 & 18 & 4.68 & 90 & 23 & 23 & \\
\hline 18 & $\mathrm{E}$ & 73.81167 & 42.71902 & 25.07 & 22 & 4.68 & 90 & 23 & 23 & \\
\hline 19 & A & 74.91871 & 42.55192 & 6.00 & 6 & 4.68 & 90 & 23 & 23 & \\
\hline 19 & B & 74.35514 & 42.53182 & 8.40 & 10 & 4.68 & 90 & 23 & 23 & \\
\hline 19 & $\mathrm{C}$ & 74.63402 & 42.52799 & 12.40 & 14 & 4.68 & 90 & 23 & 23 & \\
\hline 19 & $\mathrm{D}$ & 74.07343 & 42.52176 & 17.96 & 18 & 4.68 & 90 & 23 & 23 & \\
\hline 19 & E & 73.78888 & 42.49784 & 25.07 & 22 & 4.68 & 90 & 23 & 23 & \\
\hline 20 & A & 74.61427 & 42.33456 & 6.00 & 6 & 4.68 & 90 & 23 & 23 & \\
\hline 20 & B & 74.89227 & 42.33074 & 8.40 & 10 & 4.68 & 90 & 23 & 23 & \\
\hline 20 & $\mathrm{C}$ & 74.33343 & 42.32451 & 12.40 & 14 & 4.68 & 90 & 23 & 23 & \\
\hline 20 & $\mathrm{D}$ & 74.05264 & 42.31445 & 17.96 & 18 & 4.68 & 90 & 23 & 23 & \\
\hline
\end{tabular}




\begin{tabular}{|c|c|c|c|c|c|c|c|c|c|c|}
\hline Row & Depth & $\begin{array}{c}\text { Longitude } \\
\left({ }^{\circ} \mathbf{S}\right)\end{array}$ & $\begin{array}{c}\text { Latitude } \\
\left({ }^{\circ} \mathbf{W}\right)\end{array}$ & $\begin{array}{c}\text { Depth } \\
2 \\
\end{array}$ & Dip & Strike & Rake & Length & Width & Slip \\
\hline 20 & $\mathrm{E}$ & 73.77190 & 42.30440 & 25.07 & 22 & 4.68 & 90 & 23 & 23 & \\
\hline 21 & $\mathrm{~A}$ & 74.87166 & 42.13730 & 6.00 & 6 & 4.68 & 90 & 23 & 23 & \\
\hline 21 & B & 74.31178 & 42.11720 & 8.40 & 10 & 4.68 & 90 & 23 & 23 & \\
\hline 21 & $\mathrm{C}$ & 74.58884 & 42.11337 & 12.40 & 14 & 4.68 & 90 & 23 & 23 & \\
\hline 21 & $\mathrm{D}$ & 74.03191 & 42.10714 & 17.96 & 18 & 4.68 & 90 & 23 & 23 & \\
\hline 21 & $\mathrm{E}$ & 73.75208 & 42.09709 & 25.07 & 22 & 4.68 & 90 & 23 & 23 & \\
\hline 22 & A & 74.56920 & 41.91994 & 6.00 & 6 & 4.68 & 90 & 23 & 23 & \\
\hline 22 & B & 74.84541 & 41.91612 & 8.40 & 10 & 4.68 & 90 & 23 & 23 & \\
\hline 22 & $\mathrm{C}$ & 74.29019 & 41.90989 & 12.40 & 14 & 4.68 & 90 & 23 & 23 & \\
\hline 22 & $\mathrm{D}$ & 74.01122 & 41.89983 & 17.96 & 18 & 4.68 & 90 & 23 & 23 & \\
\hline 22 & $\mathrm{E}$ & 73.73230 & 41.88978 & 25.07 & 22 & 4.68 & 90 & 23 & 23 & \\
\hline 23 & A & 74.82494 & 41.72268 & 6.00 & 6 & 4.68 & 90 & 23 & 23 & \\
\hline 23 & $\mathrm{~B}$ & 74.26867 & 41.70258 & 8.40 & 10 & 4.68 & 90 & 23 & 23 & \\
\hline 23 & $\mathrm{C}$ & 74.54394 & 41.69875 & 12.40 & 14 & 4.68 & 90 & 23 & 23 & \\
\hline 23 & $\mathrm{D}$ & 73.99059 & 41.69252 & 17.96 & 18 & 4.68 & 90 & 23 & 23 & \\
\hline 23 & $\mathrm{E}$ & 73.71256 & 41.68247 & 25.07 & 22 & 4.68 & 90 & 23 & 23 & \\
\hline 24 & A & 74.80170 & 41.51537 & 6.00 & 6 & 4.68 & 90 & 23 & 23 & \\
\hline 24 & B & 74.52443 & 41.50532 & 8.40 & 10 & 4.68 & 90 & 23 & 23 & \\
\hline 24 & $\mathrm{C}$ & 74.24720 & 41.49527 & 12.40 & 14 & 4.68 & 90 & 23 & 23 & \\
\hline 24 & $\mathrm{D}$ & 73.97002 & 41.48521 & 17.96 & 18 & 4.68 & 90 & 23 & 23 & \\
\hline 24 & E & 73.69287 & 41.47516 & 25.07 & 22 & 4.68 & 90 & 23 & 23 & \\
\hline 25 & A & 74.77854 & 41.30806 & 6.00 & 6 & 4.68 & 90 & 23 & 23 & \\
\hline 25 & B & 74.50215 & 41.29801 & 8.40 & 10 & 4.68 & 90 & 23 & 23 & \\
\hline 25 & $\mathrm{C}$ & 74.22580 & 41.28796 & 12.40 & 14 & 4.68 & 90 & 23 & 23 & \\
\hline 25 & $\mathrm{D}$ & 73.94949 & 41.27790 & 17.96 & 18 & 4.68 & 90 & 23 & 23 & \\
\hline 25 & $\mathrm{E}$ & 73.67322 & 41.26785 & 25.07 & 22 & 4.68 & 90 & 23 & 23 & \\
\hline 26 & A & 74.75546 & 41.10075 & 6.00 & 6 & 4.68 & 90 & 23 & 23 & \\
\hline 26 & B & 74.47993 & 41.09070 & 8.40 & 10 & 4.68 & 90 & 23 & 23 & \\
\hline 26 & $\mathrm{C}$ & 74.20445 & 41.08065 & 12.40 & 14 & 4.68 & 90 & 23 & 23 & \\
\hline 26 & $\mathrm{D}$ & 73.92901 & 41.07059 & 17.96 & 18 & 4.68 & 90 & 23 & 23 & \\
\hline 26 & $\mathrm{E}$ & 73.65362 & 41.06054 & 25.07 & 22 & 4.68 & 90 & 23 & 23 & \\
\hline 27 & $\mathrm{~A}$ & 74.73245 & 40.89344 & 6.00 & 6 & 4.68 & 90 & 23 & 23 & \\
\hline 27 & B & 74.45779 & 40.88339 & 8.40 & 10 & 4.68 & 90 & 23 & 23 & \\
\hline 27 & $\mathrm{C}$ & 74.18317 & 40.87334 & 12.40 & 14 & 4.68 & 90 & 23 & 23 & \\
\hline 27 & $\mathrm{D}$ & 73.90859 & 40.86328 & 17.96 & 18 & 4.68 & 90 & 23 & 23 & \\
\hline 27 & $\mathrm{E}$ & 73.63405 & 40.85323 & 25.07 & 22 & 4.68 & 90 & 23 & 23 & \\
\hline
\end{tabular}




\begin{tabular}{|c|c|c|c|c|c|c|c|c|c|c|}
\hline Row & Depth & $\begin{array}{c}\text { Longitude } \\
\left({ }^{\circ} \mathbf{S}\right)\end{array}$ & $\begin{array}{c}\text { Latitude } \\
\left({ }^{\circ} \mathbf{W}\right)\end{array}$ & $\begin{array}{c}\text { Depth } \\
2\end{array}$ & Dip & Strike & Rake & Length & Width & Slip \\
\hline 28 & A & 74.70952 & 40.68613 & 6.00 & 6 & 4.68 & 90 & 23 & 23 & \\
\hline 28 & B & 74.43571 & 40.67608 & 8.40 & 10 & 4.68 & 90 & 23 & 23 & \\
\hline 28 & $\mathrm{C}$ & 74.16194 & 40.66603 & 12.40 & 14 & 4.68 & 90 & 23 & 23 & \\
\hline 28 & $\mathrm{D}$ & 73.88821 & 40.65597 & 17.96 & 18 & 4.68 & 90 & 23 & 23 & \\
\hline 28 & $\mathrm{E}$ & 73.61453 & 40.64592 & 25.07 & 22 & 4.68 & 90 & 23 & 23 & \\
\hline 29 & A & 74.68667 & 40.47882 & 6.00 & 6 & 4.68 & 90 & 23 & 23 & \\
\hline 29 & B & 74.41370 & 40.46877 & 8.40 & 10 & 4.68 & 90 & 23 & 23 & \\
\hline 29 & $\mathrm{C}$ & 74.14078 & 40.45872 & 12.40 & 14 & 4.68 & 90 & 23 & 23 & \\
\hline 29 & $\mathrm{D}$ & 73.86789 & 40.44866 & 17.96 & 18 & 4.68 & 90 & 23 & 23 & \\
\hline 29 & $\mathrm{E}$ & 73.59504 & 40.43861 & 25.07 & 22 & 4.68 & 90 & 23 & 23 & \\
\hline 30 & A & 74.66390 & 40.27151 & 6.00 & 6 & 4.68 & 90 & 23 & 23 & \\
\hline 30 & B & 74.39176 & 40.26146 & 8.40 & 10 & 4.68 & 90 & 23 & 23 & \\
\hline 30 & $\mathrm{C}$ & 74.11967 & 40.25141 & 12.40 & 14 & 4.68 & 90 & 23 & 23 & \\
\hline 30 & $\mathrm{D}$ & 73.84761 & 40.24135 & 17.96 & 18 & 4.68 & 90 & 23 & 23 & \\
\hline 30 & $\mathrm{E}$ & 73.57560 & 40.23130 & 25.07 & 22 & 4.68 & 90 & 23 & 23 & \\
\hline 31 & A & 74.64119 & 40.06420 & 6.00 & 6 & 4.68 & 90 & 23 & 23 & \\
\hline 31 & B & 74.36988 & 40.05415 & 8.40 & 10 & 4.68 & 90 & 23 & 23 & \\
\hline 31 & $\mathrm{C}$ & 74.09861 & 40.04410 & 12.40 & 14 & 4.68 & 90 & 23 & 23 & \\
\hline 31 & $\mathrm{D}$ & 73.82738 & 40.03404 & 17.96 & 18 & 4.68 & 90 & 23 & 23 & \\
\hline 31 & $\mathrm{E}$ & 73.55619 & 40.02399 & 25.07 & 22 & 4.68 & 90 & 23 & 23 & \\
\hline 32 & A & 74.61856 & 39.85689 & 6.00 & 6 & 4.68 & 90 & 23 & 23 & \\
\hline 32 & B & 74.34807 & 39.84684 & 8.40 & 10 & 4.68 & 90 & 23 & 23 & \\
\hline 32 & $\mathrm{C}$ & 74.07762 & 39.83679 & 12.40 & 14 & 4.68 & 90 & 23 & 23 & \\
\hline 32 & $\mathrm{D}$ & 73.80720 & 39.82673 & 17.96 & 18 & 4.68 & 90 & 23 & 23 & \\
\hline 32 & $\mathrm{E}$ & 73.53683 & 39.81668 & 25.07 & 22 & 4.68 & 90 & 23 & 23 & \\
\hline 33 & A & 74.59601 & 39.64958 & 6.00 & 6 & 4.68 & 90 & 23 & 23 & \\
\hline 33 & B & 74.32632 & 39.63953 & 8.40 & 10 & 4.68 & 90 & 23 & 23 & \\
\hline 33 & $\mathrm{C}$ & 74.05668 & 39.62948 & 12.40 & 14 & 4.68 & 90 & 23 & 23 & \\
\hline 33 & $\mathrm{D}$ & 73.78707 & 39.61942 & 17.96 & 18 & 4.68 & 90 & 23 & 23 & \\
\hline 33 & $\mathrm{E}$ & 73.51750 & 39.60937 & 25.07 & 22 & 4.68 & 90 & 23 & 23 & \\
\hline 34 & A & 74.57352 & 39.44227 & 6.00 & 6 & 4.68 & 90 & 23 & 23 & \\
\hline 34 & $\mathrm{~B}$ & 74.30464 & 39.43222 & 8.40 & 10 & 4.68 & 90 & 23 & 23 & \\
\hline 34 & $\mathrm{C}$ & 74.03579 & 39.42217 & 12.40 & 14 & 4.68 & 90 & 23 & 23 & \\
\hline 34 & $\mathrm{D}$ & 73.76698 & 39.41211 & 17.96 & 18 & 4.68 & 90 & 23 & 23 & \\
\hline 34 & $\mathrm{E}$ & 73.49821 & 39.40206 & 25.07 & 22 & 4.68 & 90 & 23 & 23 & \\
\hline 35 & A & 74.55111 & 39.23496 & 6.00 & 6 & 4.68 & 90 & 23 & 23 & \\
\hline
\end{tabular}




\begin{tabular}{|c|c|c|c|c|c|c|c|c|c|c|}
\hline Row & Depth & $\begin{array}{c}\text { Longitude } \\
\left({ }^{\circ} \mathrm{S}\right)\end{array}$ & $\begin{array}{c}\text { Latitude } \\
\left({ }^{\circ} \mathbf{W}\right)\end{array}$ & $\begin{array}{c}\text { Depth } \\
2\end{array}$ & Dip & Strike & Rake & Length & Width & Slip \\
\hline 35 & $\mathrm{~B}$ & 74.28301 & 39.22491 & 8.40 & 10 & 4.68 & 90 & 23 & 23 & \\
\hline 35 & $\mathrm{C}$ & 74.01496 & 39.21486 & 12.40 & 14 & 4.68 & 90 & 23 & 23 & \\
\hline 35 & $\mathrm{D}$ & 73.74694 & 39.20480 & 17.96 & 18 & 4.68 & 90 & 23 & 23 & \\
\hline 35 & $\mathrm{E}$ & 73.47896 & 39.19475 & 25.07 & 22 & 4.68 & 90 & 23 & 23 & \\
\hline 36 & $\mathrm{~A}$ & 74.26146 & 39.01760 & 6.00 & 6 & 4.68 & 90 & 23 & 23 & \\
\hline 36 & B & 73.99418 & 39.00755 & 8.40 & 10 & 4.68 & 90 & 23 & 23 & \\
\hline 36 & $\mathrm{C}$ & 74.52589 & 39.00061 & 12.40 & 14 & 4.68 & 90 & 23 & 23 & \\
\hline 36 & $\mathrm{D}$ & 73.72695 & 38.99749 & 17.96 & 18 & 4.68 & 90 & 23 & 23 & \\
\hline 36 & $\mathrm{E}$ & 73.45975 & 38.98744 & 25.07 & 22 & 4.68 & 90 & 23 & 23 & \\
\hline 37 & $\mathrm{~A}$ & 74.50649 & 38.82034 & 6.00 & 6 & 4.68 & 90 & 23 & 23 & \\
\hline 37 & B & 74.23996 & 38.81029 & 8.40 & 10 & 4.68 & 90 & 23 & 23 & \\
\hline 37 & $\mathrm{C}$ & 73.97346 & 38.80024 & 12.40 & 14 & 4.68 & 90 & 23 & 23 & \\
\hline 37 & $\mathrm{D}$ & 73.70700 & 38.79018 & 17.96 & 18 & 4.68 & 90 & 23 & 23 & \\
\hline 37 & $\mathrm{E}$ & 73.44058 & 38.78013 & 25.07 & 22 & 4.68 & 90 & 23 & 23 & \\
\hline 38 & $\mathrm{~A}$ & 74.50348 & 38.65588 & 6.00 & 6 & 4.68 & 90 & 23 & 23 & \\
\hline 38 & B & 73.95582 & 38.63091 & 8.40 & 10 & 4.68 & 90 & 23 & 23 & \\
\hline 38 & $\mathrm{C}$ & 74.22691 & 38.62952 & 12.40 & 14 & 4.68 & 90 & 23 & 23 & \\
\hline 38 & $\mathrm{D}$ & 73.67935 & 38.60454 & 17.96 & 18 & 4.68 & 90 & 23 & 23 & \\
\hline 38 & $\mathrm{E}$ & 73.40563 & 38.59206 & 25.07 & 22 & 4.68 & 90 & 23 & 23 & \\
\hline 39 & $\mathrm{~A}$ & 74.17278 & 38.44030 & 6.00 & 6 & 12.47 & 90 & 23 & 23 & \\
\hline 39 & B & 74.44316 & 38.43891 & 8.40 & 10 & 12.47 & 90 & 23 & 23 & \\
\hline 39 & $\mathrm{C}$ & 73.62675 & 38.41532 & 12.40 & 14 & 12.47 & 90 & 23 & 23 & \\
\hline 39 & $\mathrm{D}$ & 73.89703 & 38.41393 & 17.96 & 18 & 12.47 & 90 & 23 & 23 & \\
\hline 39 & $\mathrm{E}$ & 73.35110 & 38.38896 & 25.07 & 22 & 12.47 & 90 & 23 & 23 & \\
\hline 40 & A & 74.38842 & 38.24968 & 6.00 & 6 & 12.47 & 90 & 23 & 23 & \\
\hline 40 & B & 74.11339 & 38.22332 & 8.40 & 10 & 12.47 & 90 & 23 & 23 & \\
\hline 40 & $\mathrm{C}$ & 73.84111 & 38.21083 & 12.40 & 14 & 12.47 & 90 & 23 & 23 & \\
\hline 40 & $\mathrm{D}$ & 73.29939 & 38.19974 & 17.96 & 18 & 12.47 & 90 & 23 & 23 & \\
\hline 40 & $\mathrm{E}$ & 73.56888 & 38.19835 & 25.07 & 22 & 12.47 & 90 & 23 & 23 & \\
\hline 41 & A & 74.32844 & 38.03271 & 6.00 & 6 & 12.47 & 90 & 23 & 23 & \\
\hline 41 & B & 73.78803 & 38.02161 & 8.40 & 10 & 12.47 & 90 & 23 & 23 & \\
\hline 41 & $\mathrm{C}$ & 74.05687 & 38.02022 & 12.40 & 14 & 12.47 & 90 & 23 & 23 & \\
\hline 41 & $\mathrm{D}$ & 73.24511 & 37.99664 & 17.96 & 18 & 12.47 & 90 & 23 & 23 & \\
\hline 41 & $\mathrm{E}$ & 73.51386 & 37.99525 & 25.07 & 22 & 12.47 & 90 & 23 & 23 & \\
\hline 42 & A & 74.27133 & 37.82961 & 6.00 & 6 & 12.47 & 90 & 23 & 23 & \\
\hline 42 & B & 73.73240 & 37.81851 & 8.40 & 10 & 12.47 & 90 & 23 & 23 & \\
\hline
\end{tabular}




\begin{tabular}{|c|c|c|c|c|c|c|c|c|c|c|}
\hline Row & Depth & $\begin{array}{c}\text { Longitude } \\
\left({ }^{\circ} \mathbf{S}\right)\end{array}$ & $\begin{array}{c}\text { Latitude } \\
\left({ }^{\circ} \mathbf{W}\right)\end{array}$ & $\begin{array}{c}\text { Depth } \\
2 \\
\end{array}$ & Dip & Strike & Rake & Length & Width & Slip \\
\hline 42 & $\mathrm{C}$ & 74.00050 & 37.81712 & 12.40 & 14 & 12.47 & 90 & 23 & 23 & \\
\hline 42 & $\mathrm{D}$ & 73.45898 & 37.79215 & 17.96 & 18 & 12.47 & 90 & 23 & 23 & \\
\hline 42 & $\mathrm{E}$ & 73.18829 & 37.77966 & 25.07 & 22 & 12.47 & 90 & 23 & 23 & \\
\hline 43 & A & 74.21705 & 37.64039 & 6.00 & 6 & 12.47 & 90 & 23 & 23 & \\
\hline 43 & B & 73.94429 & 37.61402 & 8.40 & 10 & 12.47 & 90 & 23 & 23 & \\
\hline 43 & $\mathrm{C}$ & 73.40692 & 37.60293 & 12.40 & 14 & 12.47 & 90 & 23 & 23 & \\
\hline 43 & $\mathrm{D}$ & 73.67424 & 37.60154 & 17.96 & 18 & 12.47 & 90 & 23 & 23 & \\
\hline 43 & $\mathrm{E}$ & 73.13429 & 37.57656 & 25.07 & 22 & 12.47 & 90 & 23 & 23 & \\
\hline 44 & A & 73.89089 & 37.42480 & 6.00 & 6 & 12.47 & 90 & 23 & 23 & \\
\hline 44 & B & 74.15759 & 37.42341 & 8.40 & 10 & 12.47 & 90 & 23 & 23 & \\
\hline 44 & $\mathrm{C}$ & 73.61891 & 37.39844 & 12.40 & 14 & 12.47 & 90 & 23 & 23 & \\
\hline 44 & $\mathrm{D}$ & 73.34964 & 37.38595 & 17.96 & 18 & 12.47 & 90 & 23 & 23 & \\
\hline 44 & $\mathrm{E}$ & 73.08041 & 37.37346 & 25.07 & 22 & 12.47 & 90 & 23 & 23 & \\
\hline 45 & A & 74.10095 & 37.22031 & 6.00 & 6 & 12.47 & 90 & 23 & 23 & \\
\hline 45 & B & 73.83231 & 37.20783 & 8.40 & 10 & 12.47 & 90 & 23 & 23 & \\
\hline 45 & $\mathrm{C}$ & 73.56372 & 37.19534 & 12.40 & 14 & 12.47 & 90 & 23 & 23 & \\
\hline 45 & $\mathrm{D}$ & 73.29517 & 37.18285 & 17.96 & 18 & 12.47 & 90 & 23 & 23 & \\
\hline 45 & $\mathrm{E}$ & 73.02667 & 37.17037 & 25.07 & 22 & 12.47 & 90 & 23 & 23 & \\
\hline 46 & A & 74.04447 & 37.01722 & 6.00 & 6 & 12.47 & 90 & 23 & 23 & \\
\hline 46 & B & 73.77655 & 37.00473 & 8.40 & 10 & 12.47 & 90 & 23 & 23 & \\
\hline 46 & $\mathrm{C}$ & 73.50867 & 36.99224 & 12.40 & 14 & 12.47 & 90 & 23 & 23 & \\
\hline 46 & $\mathrm{D}$ & 73.24084 & 36.97975 & 17.96 & 18 & 12.47 & 90 & 23 & 23 & \\
\hline 46 & $\mathrm{E}$ & 72.97305 & 36.96727 & 25.07 & 22 & 12.47 & 90 & 23 & 23 & \\
\hline 47 & A & 73.98815 & 36.81412 & 6.00 & 6 & 12.47 & 90 & 23 & 23 & \\
\hline 47 & B & 73.72093 & 36.80163 & 8.40 & 10 & 12.47 & 90 & 23 & 23 & \\
\hline 47 & $\mathrm{C}$ & 73.45376 & 36.78914 & 12.40 & 14 & 12.47 & 90 & 23 & 23 & \\
\hline 47 & D & 73.18664 & 36.77666 & 17.96 & 18 & 12.47 & 90 & 23 & 23 & \\
\hline 47 & $\mathrm{E}$ & 72.91955 & 36.76417 & 25.07 & 22 & 12.47 & 90 & 23 & 23 & \\
\hline 48 & A & 73.93198 & 36.61102 & 6.00 & 6 & 12.47 & 90 & 23 & 23 & \\
\hline 48 & B & 73.66546 & 36.59853 & 8.40 & 10 & 12.47 & 90 & 23 & 23 & \\
\hline 48 & $\mathrm{C}$ & 73.39900 & 36.58604 & 12.40 & 14 & 12.47 & 90 & 23 & 23 & \\
\hline 48 & $\mathrm{D}$ & 73.13257 & 36.57356 & 17.96 & 18 & 12.47 & 90 & 23 & 23 & \\
\hline 48 & $\mathrm{E}$ & 72.86619 & 36.56107 & 25.07 & 22 & 12.47 & 90 & 23 & 23 & \\
\hline 49 & A & 73.87596 & 36.40792 & 6.00 & 6 & 12.47 & 90 & 23 & 23 & \\
\hline 49 & B & 73.61014 & 36.39543 & 8.40 & 10 & 12.47 & 90 & 23 & 23 & \\
\hline 49 & $\mathrm{C}$ & 73.34437 & 36.38294 & 12.40 & 14 & 12.47 & 90 & 23 & 23 & \\
\hline
\end{tabular}




\begin{tabular}{|c|c|c|c|c|c|c|c|c|c|c|}
\hline Row & Depth & $\begin{array}{c}\text { Longitude } \\
\left({ }^{\circ} \mathrm{S}\right)\end{array}$ & $\begin{array}{c}\text { Latitude } \\
\left({ }^{\circ} \mathbf{W}\right)\end{array}$ & $\begin{array}{c}\text { Depth } \\
2\end{array}$ & Dip & Strike & Rake & Length & Width & Slip \\
\hline 49 & $\mathrm{D}$ & 73.07863 & 36.37046 & 17.96 & 18 & 12.47 & 90 & 23 & 23 & \\
\hline 49 & $\mathrm{E}$ & 72.81294 & 36.35797 & 25.07 & 22 & 12.47 & 90 & 23 & 23 & \\
\hline 50 & $\mathrm{~A}$ & 73.82009 & 36.20482 & 6.00 & 6 & 12.47 & 90 & 23 & 23 & \\
\hline 50 & B & 73.55496 & 36.19233 & 8.40 & 10 & 12.47 & 90 & 23 & 23 & \\
\hline 50 & $\mathrm{C}$ & 73.28987 & 36.17985 & 12.40 & 14 & 12.47 & 90 & 23 & 23 & \\
\hline 50 & $\mathrm{D}$ & 73.02483 & 36.16736 & 17.96 & 18 & 12.47 & 90 & 23 & 23 & \\
\hline 50 & $\mathrm{E}$ & 72.75982 & 36.15487 & 25.07 & 22 & 12.47 & 90 & 23 & 23 & \\
\hline 51 & A & 73.76437 & 36.00172 & 6.00 & 6 & 12.47 & 90 & 23 & 23 & \\
\hline 51 & B & 73.49992 & 35.98923 & 8.40 & 10 & 12.47 & 90 & 23 & 23 & \\
\hline 51 & $\mathrm{C}$ & 73.23551 & 35.97675 & 12.40 & 14 & 12.47 & 90 & 23 & 23 & \\
\hline 51 & $\mathrm{D}$ & 72.97115 & 35.96426 & 17.96 & 18 & 12.47 & 90 & 23 & 23 & \\
\hline 51 & $\mathrm{E}$ & 72.70682 & 35.95177 & 25.07 & 22 & 12.47 & 90 & 23 & 23 & \\
\hline 52 & $\mathrm{~A}$ & 73.70879 & 35.79862 & 6.00 & 6 & 12.47 & 90 & 23 & 23 & \\
\hline 52 & B & 73.44502 & 35.78614 & 8.40 & 10 & 12.47 & 90 & 23 & 23 & \\
\hline 52 & $\mathrm{C}$ & 73.18128 & 35.77365 & 12.40 & 14 & 12.47 & 90 & 23 & 23 & \\
\hline 52 & $\mathrm{D}$ & 72.91759 & 35.76116 & 17.96 & 18 & 12.47 & 90 & 23 & 23 & \\
\hline 52 & $\mathrm{E}$ & 72.65394 & 35.74867 & 25.07 & 22 & 12.47 & 90 & 23 & 23 & \\
\hline 53 & A & 73.65336 & 35.59552 & 6.00 & 6 & 12.47 & 90 & 23 & 23 & \\
\hline 53 & B & 73.39026 & 35.58304 & 8.40 & 10 & 12.47 & 90 & 23 & 23 & \\
\hline 53 & $\mathrm{C}$ & 73.12719 & 35.57055 & 12.40 & 14 & 12.47 & 90 & 23 & 23 & \\
\hline 53 & $\mathrm{D}$ & 72.86416 & 35.55806 & 17.96 & 18 & 12.47 & 90 & 23 & 23 & \\
\hline 53 & $\mathrm{E}$ & 72.60118 & 35.54558 & 25.07 & 22 & 12.47 & 90 & 23 & 23 & \\
\hline 54 & $\mathrm{~A}$ & 73.59808 & 35.39242 & 6.00 & 6 & 12.47 & 90 & 23 & 23 & \\
\hline 54 & B & 73.33563 & 35.37994 & 8.40 & 10 & 12.47 & 90 & 23 & 23 & \\
\hline 54 & $\mathrm{C}$ & 73.07323 & 35.36745 & 12.40 & 14 & 12.47 & 90 & 23 & 23 & \\
\hline 54 & $\mathrm{D}$ & 72.81086 & 35.35496 & 17.96 & 18 & 12.47 & 90 & 23 & 23 & \\
\hline 54 & $\mathrm{E}$ & 72.54854 & 35.34248 & 25.07 & 22 & 12.47 & 90 & 23 & 23 & \\
\hline 55 & A & 73.54294 & 35.18933 & 6.00 & 6 & 12.47 & 90 & 23 & 23 & \\
\hline 55 & B & 73.28115 & 35.17684 & 8.40 & 10 & 12.47 & 90 & 23 & 23 & \\
\hline 55 & $\mathrm{C}$ & 73.01939 & 35.16435 & 12.40 & 14 & 12.47 & 90 & 23 & 23 & \\
\hline 55 & $\mathrm{D}$ & 72.75768 & 35.15186 & 17.96 & 18 & 12.47 & 90 & 23 & 23 & \\
\hline 55 & $\mathrm{E}$ & 72.49601 & 35.13938 & 25.07 & 22 & 12.47 & 90 & 23 & 23 & \\
\hline 56 & A & 73.48794 & 34.98623 & 6.00 & 6 & 12.47 & 90 & 23 & 23 & \\
\hline 56 & B & 73.22679 & 34.97374 & 8.40 & 10 & 12.47 & 90 & 23 & 23 & \\
\hline 56 & $\mathrm{C}$ & 72.96569 & 34.96125 & 12.40 & 14 & 12.47 & 90 & 23 & 23 & \\
\hline 56 & $\mathrm{D}$ & 72.70462 & 34.94877 & 17.96 & 18 & 12.47 & 90 & 23 & 23 & \\
\hline
\end{tabular}




\begin{tabular}{|c|c|c|c|c|c|c|c|c|c|c|}
\hline Row & Depth & $\begin{array}{c}\text { Longitude } \\
\left({ }^{\circ} \mathrm{S}\right)\end{array}$ & $\begin{array}{c}\text { Latitude } \\
\left({ }^{\circ} \mathbf{W}\right)\end{array}$ & $\begin{array}{c}\text { Depth } \\
2\end{array}$ & Dip & Strike & Rake & Length & Width & Slip \\
\hline 56 & $\mathrm{E}$ & 72.44360 & 34.93628 & 25.07 & 22 & 12.47 & 90 & 23 & 23 & \\
\hline 57 & A & 73.43308 & 34.78313 & 6.00 & 6 & 12.47 & 90 & 23 & 23 & \\
\hline 57 & B & 73.17257 & 34.77064 & 8.40 & 10 & 12.47 & 90 & 23 & 23 & \\
\hline 57 & $\mathrm{C}$ & 72.91211 & 34.75815 & 12.40 & 14 & 12.47 & 90 & 23 & 23 & \\
\hline 57 & $\mathrm{D}$ & 72.65168 & 34.74567 & 17.96 & 18 & 12.47 & 90 & 23 & 23 & \\
\hline 57 & $\mathrm{E}$ & 72.39130 & 34.73318 & 25.07 & 22 & 12.47 & 90 & 23 & 23 & \\
\hline 58 & $\mathrm{~A}$ & 73.37836 & 34.58003 & 6.00 & 6 & 12.47 & 90 & 23 & 23 & \\
\hline 58 & B & 73.11849 & 34.56754 & 8.40 & 10 & 12.47 & 90 & 23 & 23 & \\
\hline 58 & $\mathrm{C}$ & 72.85866 & 34.55506 & 12.40 & 14 & 12.47 & 90 & 23 & 23 & \\
\hline 58 & $\mathrm{D}$ & 72.59886 & 34.54257 & 17.96 & 18 & 12.47 & 90 & 23 & 23 & \\
\hline 58 & $\mathrm{E}$ & 72.33911 & 34.53008 & 25.07 & 22 & 12.47 & 90 & 23 & 23 & \\
\hline 59 & A & 73.32377 & 34.37693 & 6.00 & 6 & 12.47 & 90 & 23 & 23 & \\
\hline 59 & B & 73.06453 & 34.36444 & 8.40 & 10 & 12.47 & 90 & 23 & 23 & \\
\hline 59 & $\mathrm{C}$ & 72.80533 & 34.35196 & 12.40 & 14 & 12.47 & 90 & 23 & 23 & \\
\hline 59 & $\mathrm{D}$ & 72.54616 & 34.33947 & 17.96 & 18 & 12.47 & 90 & 23 & 23 & \\
\hline 59 & $\mathrm{E}$ & 72.28704 & 34.32698 & 25.07 & 22 & 12.47 & 90 & 23 & 23 & \\
\hline 60 & A & 73.26932 & 34.17383 & 6.00 & 6 & 12.47 & 90 & 23 & 23 & \\
\hline 60 & B & 73.01070 & 34.16134 & 8.40 & 10 & 12.47 & 90 & 23 & 23 & \\
\hline 60 & $\mathrm{C}$ & 72.75212 & 34.14886 & 12.40 & 14 & 12.47 & 90 & 23 & 23 & \\
\hline 60 & $\mathrm{D}$ & 72.49358 & 34.13637 & 17.96 & 18 & 12.47 & 90 & 23 & 23 & \\
\hline 60 & $E$ & 72.23507 & 34.12388 & 25.07 & 22 & 12.47 & 90 & 23 & 23 & \\
\hline 61 & A & 73.21501 & 33.97073 & 6.00 & 6 & 12.47 & 90 & 23 & 23 & \\
\hline 61 & B & 72.95701 & 33.95825 & 8.40 & 10 & 12.47 & 90 & 23 & 23 & \\
\hline 61 & $\mathrm{C}$ & 72.69904 & 33.94576 & 12.40 & 14 & 12.47 & 90 & 23 & 23 & \\
\hline 61 & $\mathrm{D}$ & 72.44111 & 33.93327 & 17.96 & 18 & 12.47 & 90 & 23 & 23 & \\
\hline 61 & $E$ & 72.18322 & 33.92078 & 25.07 & 22 & 12.47 & 90 & 23 & 23 & \\
\hline 62 & A & 73.16083 & 33.76763 & 6.00 & 6 & 12.47 & 90 & 23 & 23 & \\
\hline 62 & B & 72.90343 & 33.75515 & 8.40 & 10 & 12.47 & 90 & 23 & 23 & \\
\hline 62 & $\mathrm{C}$ & 72.64608 & 33.74266 & 12.40 & 14 & 12.47 & 90 & 23 & 23 & \\
\hline 62 & D & 72.38876 & 33.73017 & 17.96 & 18 & 12.47 & 90 & 23 & 23 & \\
\hline 62 & $\mathrm{E}$ & 72.13148 & 33.71769 & 25.07 & 22 & 12.47 & 90 & 23 & 23 & \\
\hline 63 & A & 73.10678 & 33.56453 & 6.00 & 6 & 12.47 & 90 & 23 & 23 & \\
\hline 63 & B & 72.84999 & 33.55205 & 8.40 & 10 & 12.47 & 90 & 23 & 23 & \\
\hline 63 & $\mathrm{C}$ & 72.59323 & 33.53956 & 12.40 & 14 & 12.47 & 90 & 23 & 23 & \\
\hline 63 & $\mathrm{D}$ & 72.33652 & 33.52707 & 17.96 & 18 & 12.47 & 90 & 23 & 23 & \\
\hline 63 & $\mathrm{E}$ & 72.07984 & 33.51459 & 25.07 & 22 & 12.47 & 90 & 23 & 23 & \\
\hline
\end{tabular}




\begin{tabular}{|c|c|c|c|c|c|c|c|c|c|c|}
\hline Row & Depth & $\begin{array}{c}\text { Longitude } \\
\left({ }^{\circ} \mathbf{S}\right)\end{array}$ & $\begin{array}{c}\text { Latitude } \\
\left({ }^{\circ} \mathbf{W}\right)\end{array}$ & $\begin{array}{c}\text { Depth } \\
2\end{array}$ & Dip & Strike & Rake & Length & Width & Slip \\
\hline 64 & A & 73.05286 & 33.36144 & 6.00 & 6 & 12.47 & 90 & 23 & 23 & \\
\hline 64 & B & 72.79667 & 33.34895 & 8.40 & 10 & 12.47 & 90 & 23 & 23 & \\
\hline 64 & $\mathrm{C}$ & 72.54051 & 33.33646 & 12.40 & 14 & 12.47 & 90 & 23 & 23 & \\
\hline 64 & $\mathrm{D}$ & 72.28439 & 33.32397 & 17.96 & 18 & 12.47 & 90 & 23 & 23 & \\
\hline 64 & $\mathrm{E}$ & 72.02831 & 33.31149 & 25.07 & 22 & 12.47 & 90 & 23 & 23 & \\
\hline 65 & A & 72.99907 & 33.15834 & 6.00 & 6 & 12.47 & 90 & 23 & 23 & \\
\hline 65 & B & 72.74347 & 33.14585 & 8.40 & 10 & 12.47 & 90 & 23 & 23 & \\
\hline 65 & $\mathrm{C}$ & 72.48790 & 33.13336 & 12.40 & 14 & 12.47 & 90 & 23 & 23 & \\
\hline 65 & $\mathrm{D}$ & 72.23237 & 33.12088 & 17.96 & 18 & 12.47 & 90 & 23 & 23 & \\
\hline 65 & $\mathrm{E}$ & 71.97688 & 33.10839 & 25.07 & 22 & 12.47 & 90 & 23 & 23 & \\
\hline 66 & A & 72.94541 & 32.95524 & 6.00 & 6 & 12.47 & 90 & 23 & 23 & \\
\hline 66 & B & 72.69039 & 32.94275 & 8.40 & 10 & 12.47 & 90 & 23 & 23 & \\
\hline 66 & $\mathrm{C}$ & 72.43541 & 32.93026 & 12.40 & 14 & 12.47 & 90 & 23 & 23 & \\
\hline 66 & $\mathrm{D}$ & 72.18047 & 32.91778 & 17.96 & 18 & 12.47 & 90 & 23 & 23 & \\
\hline 66 & $\mathrm{E}$ & 71.92556 & 32.90529 & 25.07 & 22 & 12.47 & 90 & 23 & 23 & \\
\hline 67 & A & 72.89187 & 32.75214 & 6.00 & 6 & 12.47 & 90 & 23 & 23 & \\
\hline 67 & B & 72.63744 & 32.73965 & 8.40 & 10 & 12.47 & 90 & 23 & 23 & \\
\hline 67 & $\mathrm{C}$ & 72.38303 & 32.72717 & 12.40 & 14 & 12.47 & 90 & 23 & 23 & \\
\hline 67 & $\mathrm{D}$ & 72.12867 & 32.71468 & 17.96 & 18 & 12.47 & 90 & 23 & 23 & \\
\hline 67 & $\mathrm{E}$ & 71.87434 & 32.70219 & 25.07 & 22 & 12.47 & 90 & 23 & 23 & \\
\hline 68 & A & 72.83846 & 32.54904 & 6.00 & 6 & 12.47 & 90 & 23 & 23 & \\
\hline 68 & B & 72.58460 & 32.53655 & 8.40 & 10 & 12.47 & 90 & 23 & 23 & \\
\hline 68 & $\mathrm{C}$ & 72.33077 & 32.52407 & 12.40 & 14 & 12.47 & 90 & 23 & 23 & \\
\hline 68 & $\mathrm{D}$ & 72.07698 & 32.51158 & 17.96 & 18 & 12.47 & 90 & 23 & 23 & \\
\hline 68 & $\mathrm{E}$ & 71.82322 & 32.49909 & 25.07 & 22 & 12.47 & 90 & 23 & 23 & \\
\hline 69 & A & 72.78517 & 32.34594 & 6.00 & 6 & 12.47 & 90 & 23 & 23 & \\
\hline 69 & B & 72.53188 & 32.33345 & 8.40 & 10 & 12.47 & 90 & 23 & 23 & \\
\hline 69 & $\mathrm{C}$ & 72.27862 & 32.32097 & 12.40 & 14 & 12.47 & 90 & 23 & 23 & \\
\hline 69 & $\mathrm{D}$ & 72.02540 & 32.30848 & 17.96 & 18 & 12.47 & 90 & 23 & 23 & \\
\hline 69 & $\mathrm{E}$ & 71.77221 & 32.29599 & 25.07 & 22 & 12.47 & 90 & 23 & 23 & \\
\hline 70 & A & 72.73201 & 32.14284 & 6.00 & 6 & 12.47 & 90 & 23 & 23 & \\
\hline 70 & $\mathrm{~B}$ & 72.47928 & 32.13036 & 8.40 & 10 & 12.47 & 90 & 23 & 23 & \\
\hline 70 & $\mathrm{C}$ & 72.22658 & 32.11787 & 12.40 & 14 & 12.47 & 90 & 23 & 23 & \\
\hline 70 & D & 71.97392 & 32.10538 & 17.96 & 18 & 12.47 & 90 & 23 & 23 & \\
\hline 70 & $\mathrm{E}$ & 71.72129 & 32.09289 & 25.07 & 22 & 12.47 & 90 & 23 & 23 & \\
\hline 71 & A & 72.67897 & 31.93974 & 6.00 & 6 & 12.47 & 90 & 23 & 23 & \\
\hline
\end{tabular}




\begin{tabular}{|c|c|c|c|c|c|c|c|c|c|c|}
\hline Row & Depth & $\begin{array}{c}\text { Longitude } \\
\left({ }^{\circ} \mathrm{S}\right)\end{array}$ & $\begin{array}{c}\text { Latitude } \\
\left({ }^{\circ} \mathbf{W}\right)\end{array}$ & $\begin{array}{c}\text { Depth } \\
2 \\
\end{array}$ & Dip & Strike & Rake & Length & Width & Slip \\
\hline 71 & B & 72.42679 & 31.92726 & 8.40 & 10 & 12.47 & 90 & 23 & 23 & \\
\hline 71 & $\mathrm{C}$ & 72.17465 & 31.91477 & 12.40 & 14 & 12.47 & 90 & 23 & 23 & \\
\hline 71 & $\mathrm{D}$ & 71.92255 & 31.90228 & 17.96 & 18 & 12.47 & 90 & 23 & 23 & \\
\hline 71 & $\mathrm{E}$ & 71.67048 & 31.88980 & 25.07 & 22 & 12.47 & 90 & 23 & 23 & \\
\hline 72 & A & 72.62605 & 31.73665 & 6.00 & 6 & 12.47 & 90 & 23 & 23 & \\
\hline 72 & B & 72.37442 & 31.72416 & 8.40 & 10 & 12.47 & 90 & 23 & 23 & \\
\hline 72 & $\mathrm{C}$ & 72.12283 & 31.71167 & 12.40 & 14 & 12.47 & 90 & 23 & 23 & \\
\hline 72 & $\mathrm{D}$ & 71.87128 & 31.69918 & 17.96 & 18 & 12.47 & 90 & 23 & 23 & \\
\hline 72 & $\mathrm{E}$ & 71.61976 & 31.68670 & 25.07 & 22 & 12.47 & 90 & 23 & 23 & \\
\hline 73 & $\mathrm{~A}$ & 72.57324 & 31.53355 & 6.00 & 6 & 12.47 & 90 & 23 & 23 & \\
\hline 73 & B & 72.32217 & 31.52106 & 8.40 & 10 & 12.47 & 90 & 23 & 23 & \\
\hline 73 & $\mathrm{C}$ & 72.07112 & 31.50857 & 12.40 & 14 & 12.47 & 90 & 23 & 23 & \\
\hline 73 & $\mathrm{D}$ & 71.82011 & 31.49609 & 17.96 & 18 & 12.47 & 90 & 23 & 23 & \\
\hline 73 & $\mathrm{E}$ & 71.56913 & 31.48360 & 25.07 & 22 & 12.47 & 90 & 23 & 23 & \\
\hline 74 & $\mathrm{~A}$ & 72.52056 & 31.33045 & 6.00 & 6 & 12.47 & 90 & 23 & 23 & \\
\hline 74 & B & 72.27002 & 31.31796 & 8.40 & 10 & 12.47 & 90 & 23 & 23 & \\
\hline 74 & $\mathrm{C}$ & 72.01952 & 31.30547 & 12.40 & 14 & 12.47 & 90 & 23 & 23 & \\
\hline 74 & $\mathrm{D}$ & 71.76905 & 31.29299 & 17.96 & 18 & 12.47 & 90 & 23 & 23 & \\
\hline 74 & $\mathrm{E}$ & 71.51861 & 31.28050 & 25.07 & 22 & 12.47 & 90 & 23 & 23 & \\
\hline 75 & A & 72.46799 & 31.12735 & 6.00 & 6 & 12.47 & 90 & 23 & 23 & \\
\hline 75 & B & 72.21799 & 31.11486 & 8.40 & 10 & 12.47 & 90 & 23 & 23 & \\
\hline 75 & $\mathrm{C}$ & 71.96802 & 31.10237 & 12.40 & 14 & 12.47 & 90 & 23 & 23 & \\
\hline 75 & $\mathrm{D}$ & 71.71808 & 31.08989 & 17.96 & 18 & 12.47 & 90 & 23 & 23 & \\
\hline 75 & $\mathrm{E}$ & 71.46818 & 31.07740 & 25.07 & 22 & 12.47 & 90 & 23 & 23 & \\
\hline 76 & A & 72.41554 & 30.92425 & 6.00 & 6 & 12.47 & 90 & 23 & 23 & \\
\hline 76 & B & 72.16607 & 30.91176 & 8.40 & 10 & 12.47 & 90 & 23 & 23 & \\
\hline 76 & $\mathrm{C}$ & 71.91663 & 30.89928 & 12.40 & 14 & 12.47 & 90 & 23 & 23 & \\
\hline 76 & $\mathrm{D}$ & 71.66722 & 30.88679 & 17.96 & 18 & 12.47 & 90 & 23 & 23 & \\
\hline 76 & $\mathrm{E}$ & 71.41784 & 30.87430 & 25.07 & 22 & 12.47 & 90 & 23 & 23 & \\
\hline
\end{tabular}




\section{APPENDIX B}

\section{Stochas tic variable slips}
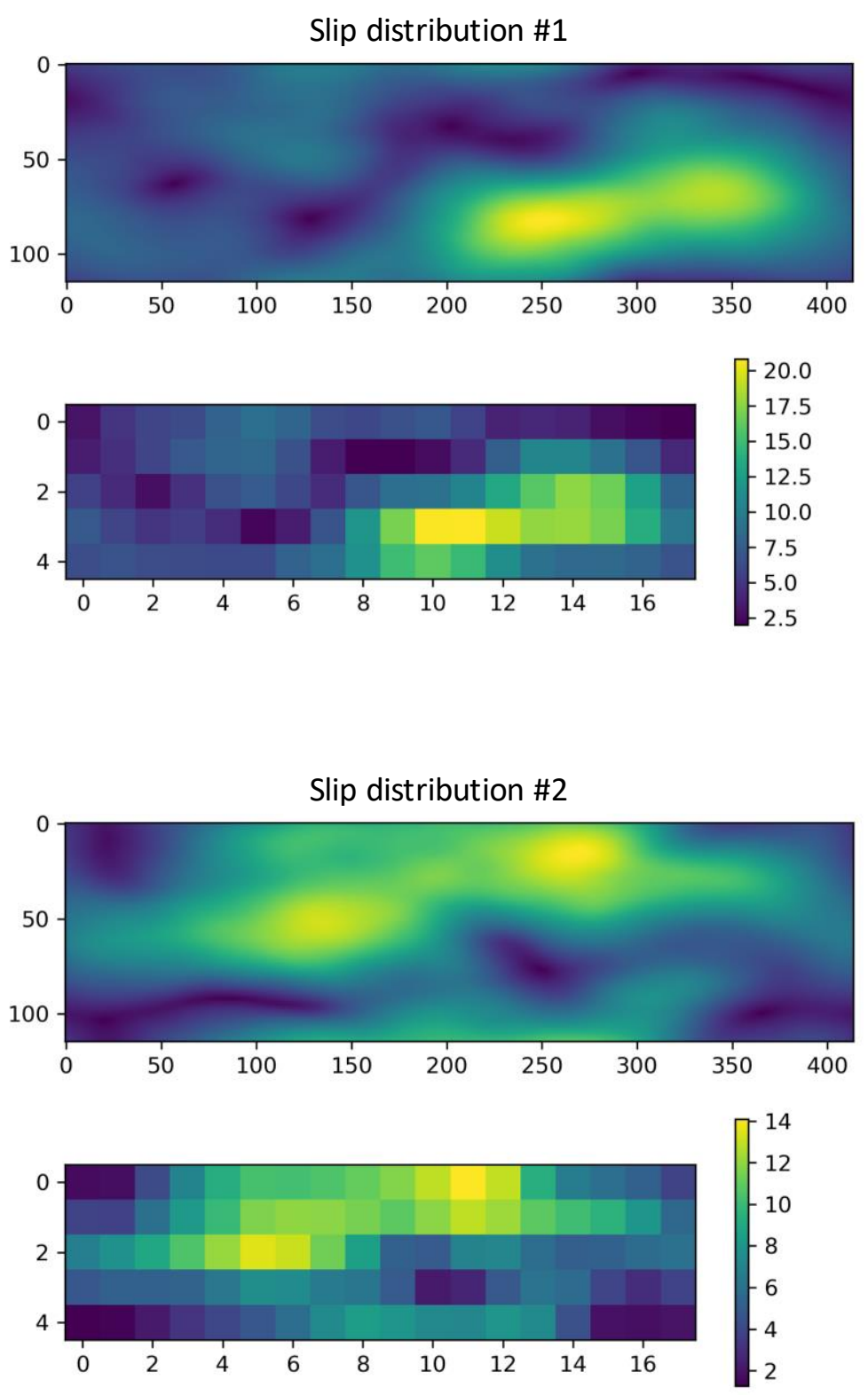

Figure B1: The three $\mathrm{M}_{\mathrm{w}} 8.7$ stochastic variable slip distributions in planar view (top) and cross-sectional view (bottom) used to generate earthquake source models. Brighter colors correspond to greater slip. 
Slip distribution \#3
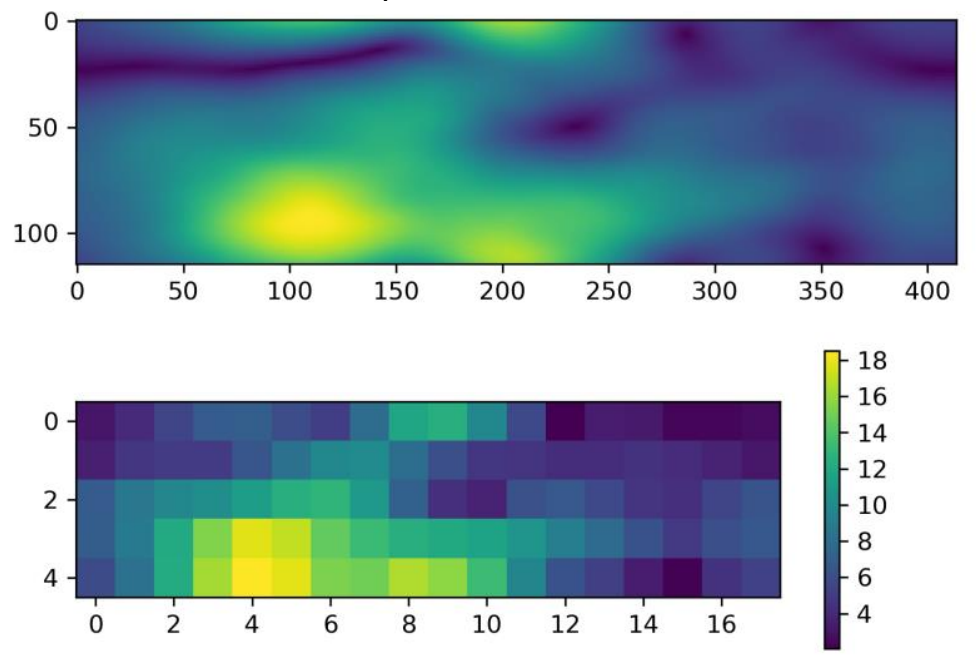

Figure B1: Continued. 

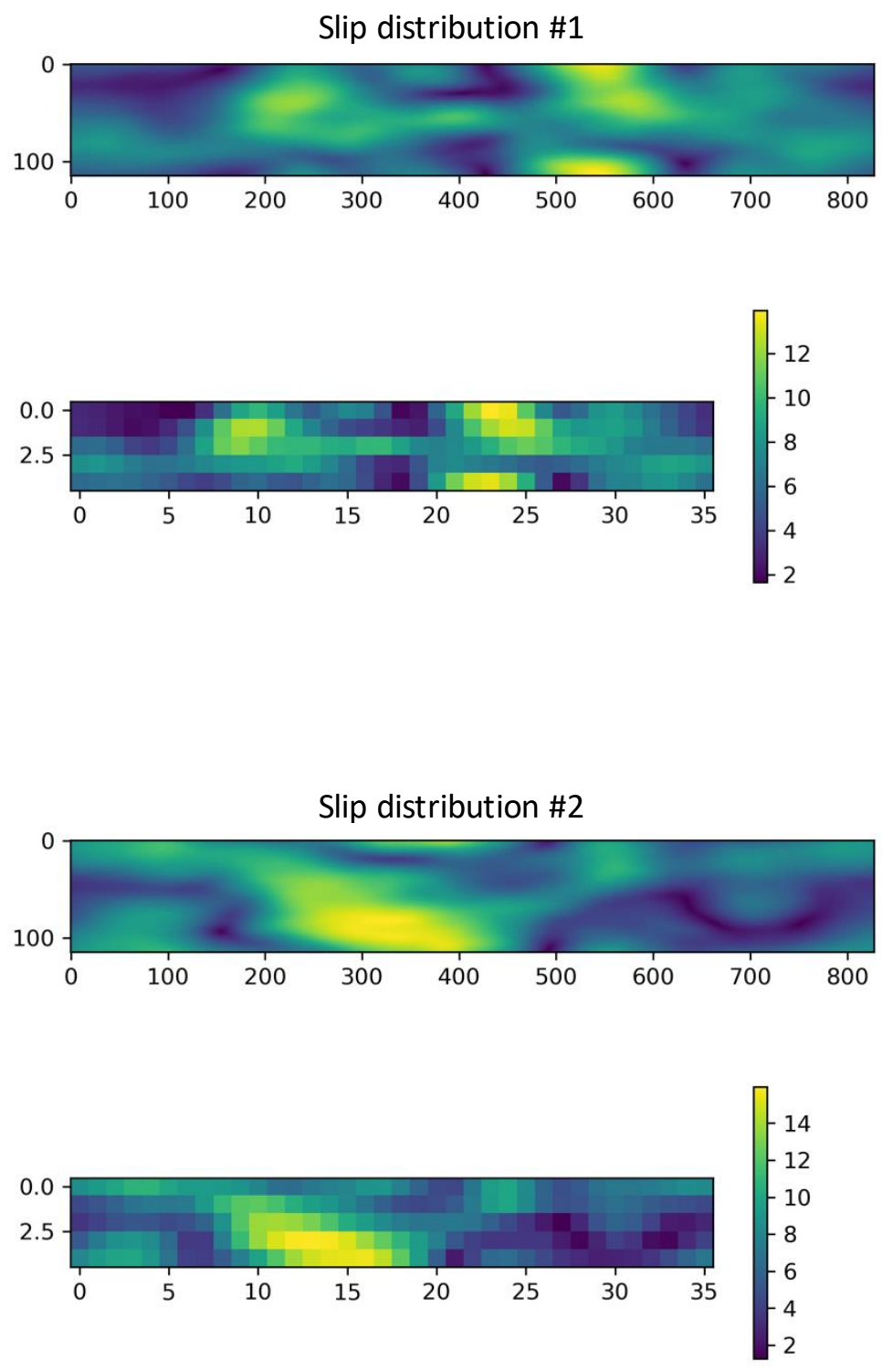

Figure B2: The three $\mathrm{M}_{\mathrm{w}} 8.9$ stochastic variable slip distributions in planar view (top) and cross-sectional view (bottom) used to generate earthquake source models. Brighter colors correspond to greater slip. 
Slip distribution \#3
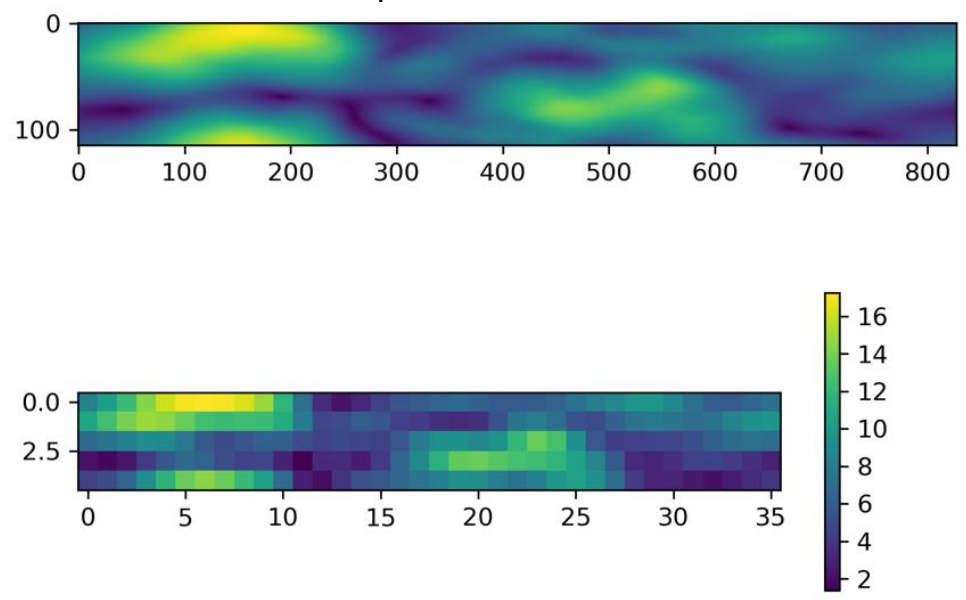

Figure B2: Continued. 

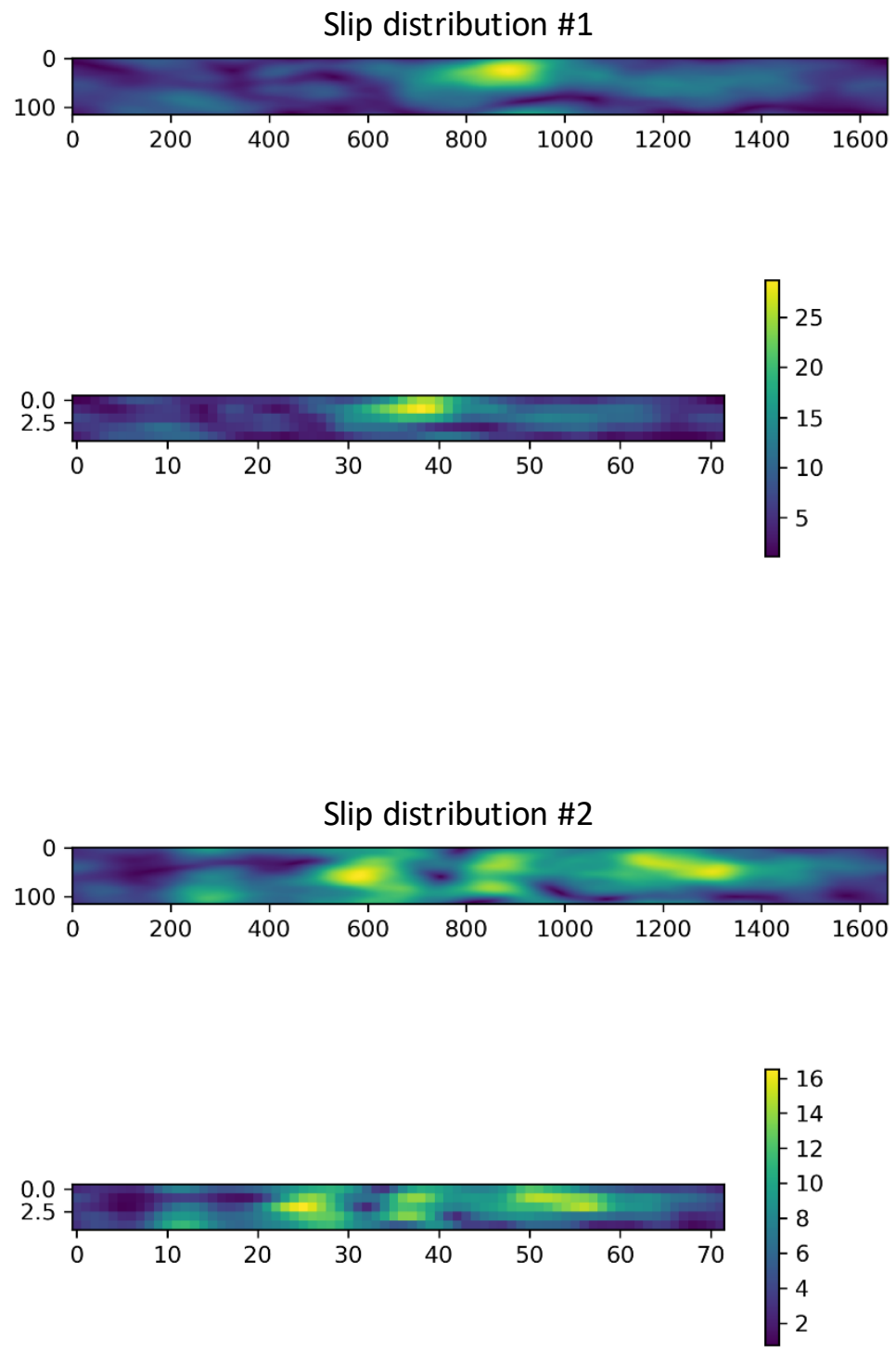

Figure B3: The ten $\mathrm{M}_{\mathrm{w}}$ 9.1 stochastic variable slip distributions in planar view (top) and cross-sectional view (bottom) used to generate earthquake source models. Brighter colors correspond to greater slip. 
Slip distribution \#3
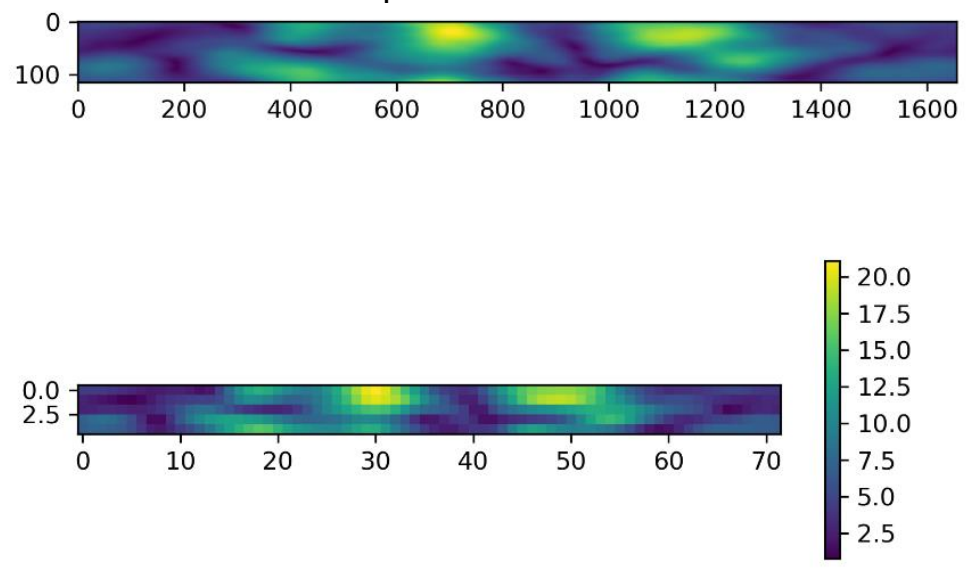

Slip distribution \#4
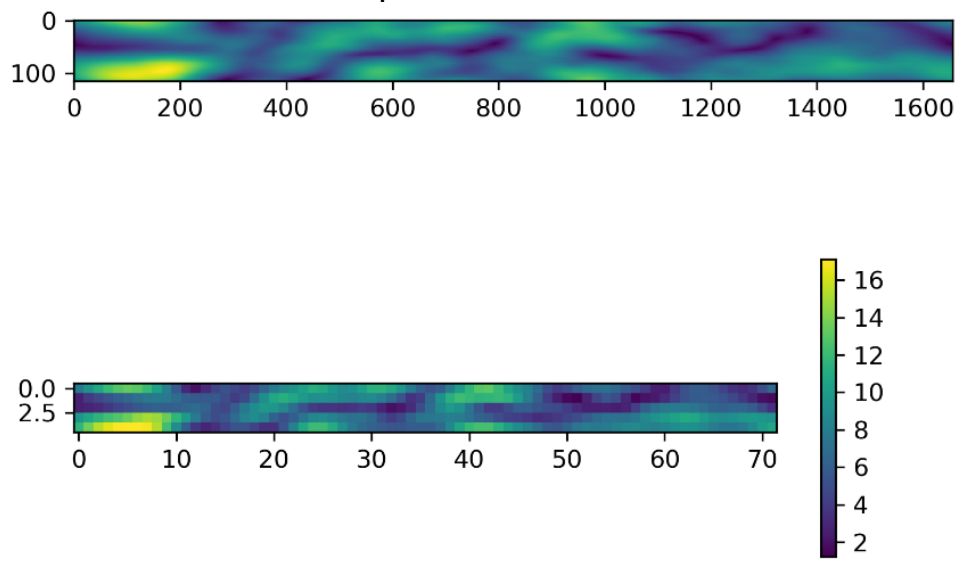

Figure B3: Continued. 

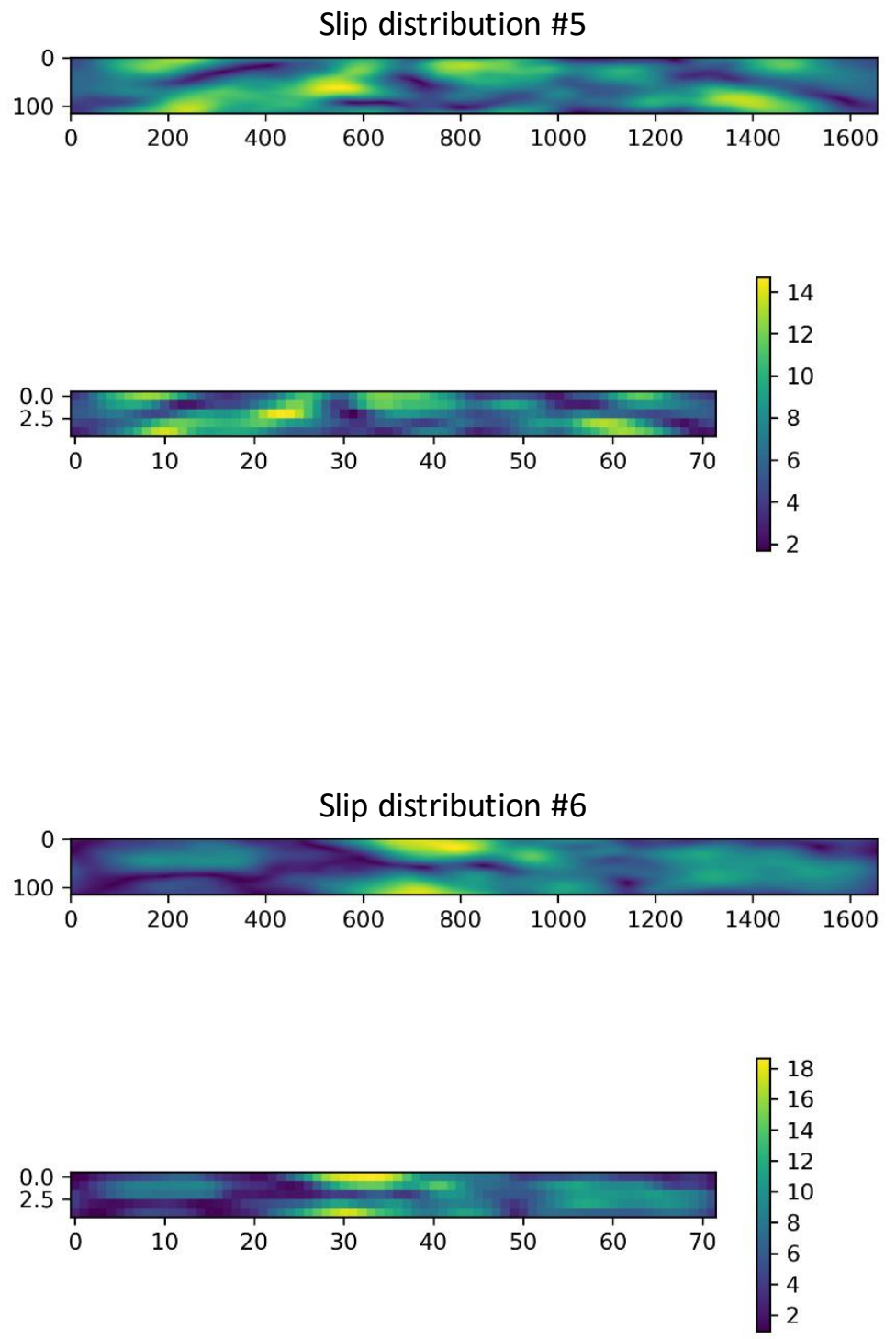

Figure B3: Continued. 

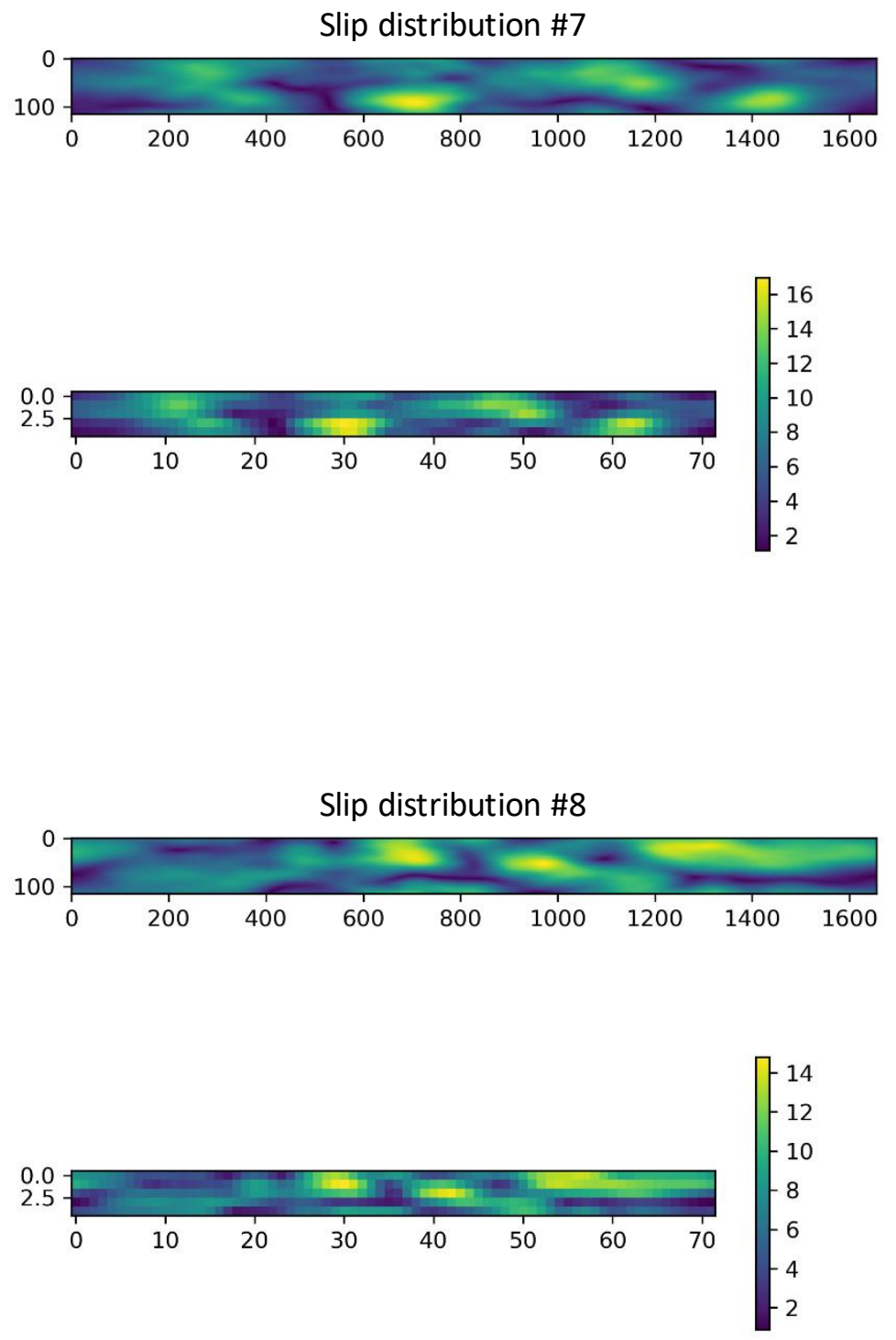

Figure B3: Continued. 

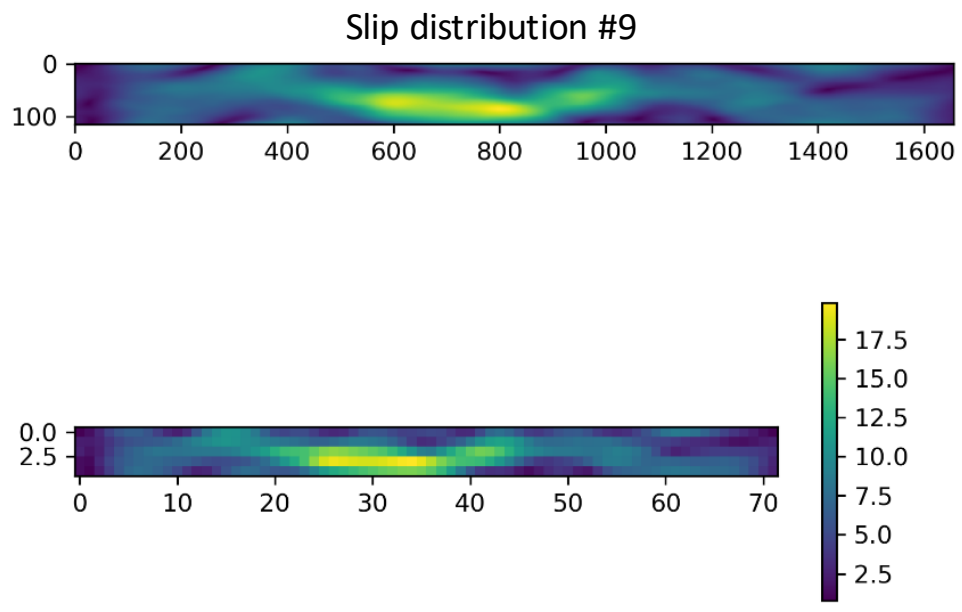

Slip distribution \#10
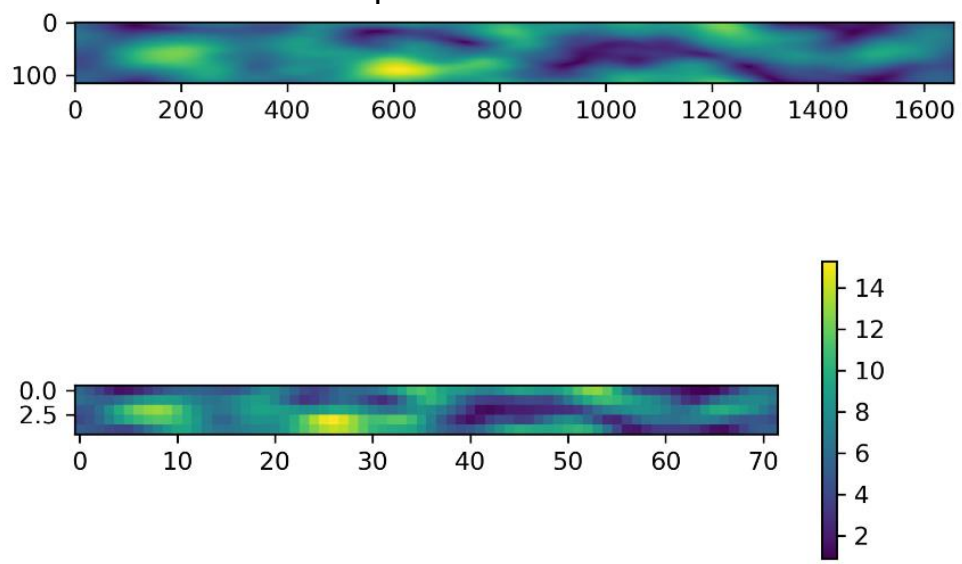

Figure B3: Continued. 

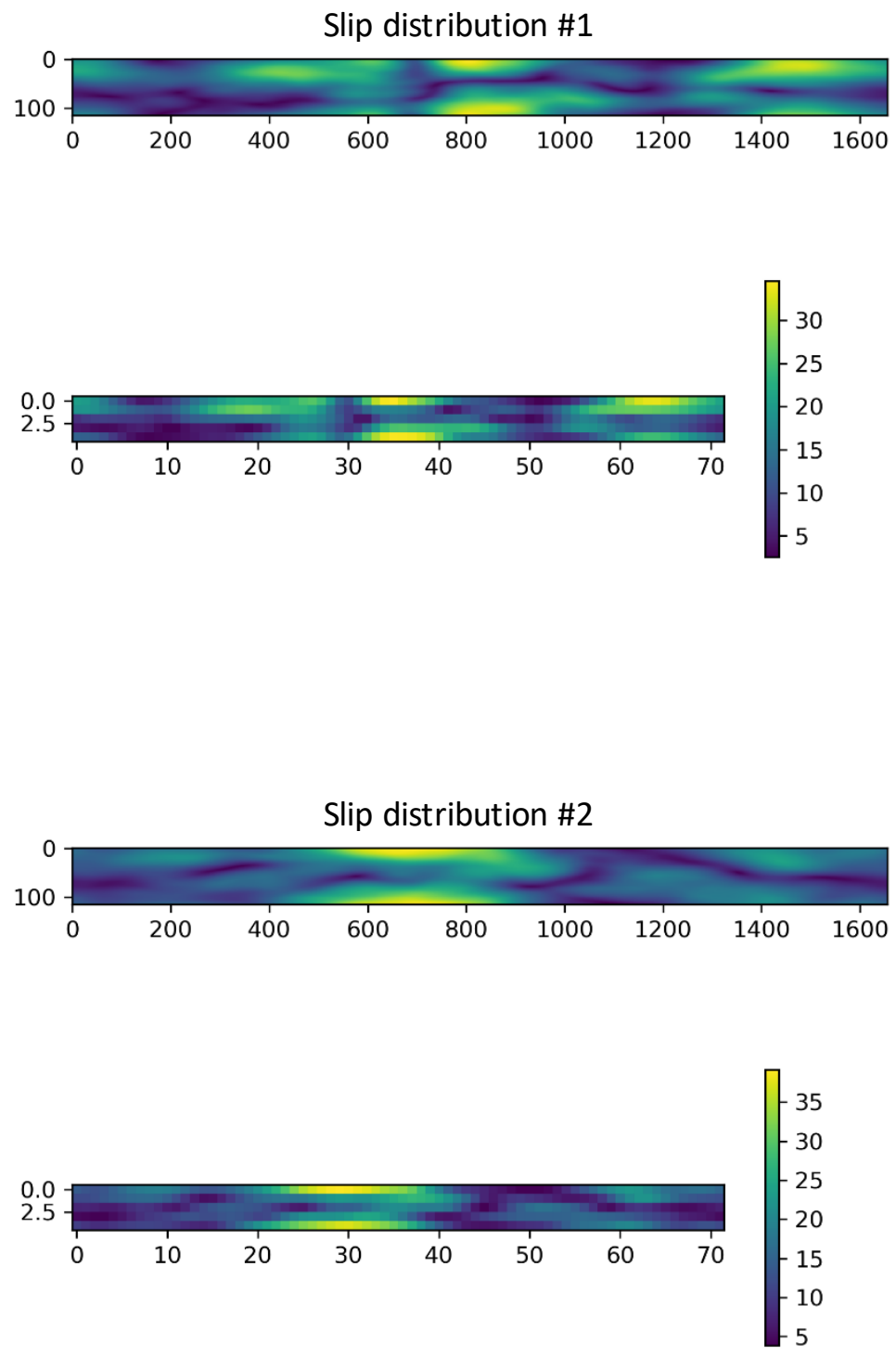

Figure B4: The ten $\mathrm{M}_{\mathrm{w}} 9.3$ stochastic variable slip distributions in planar view (top) and cross-sectional view (bottom) used to generate earthquake source models. Brighter colors correspond to greater slip. 


\section{Slip distribution \#3}
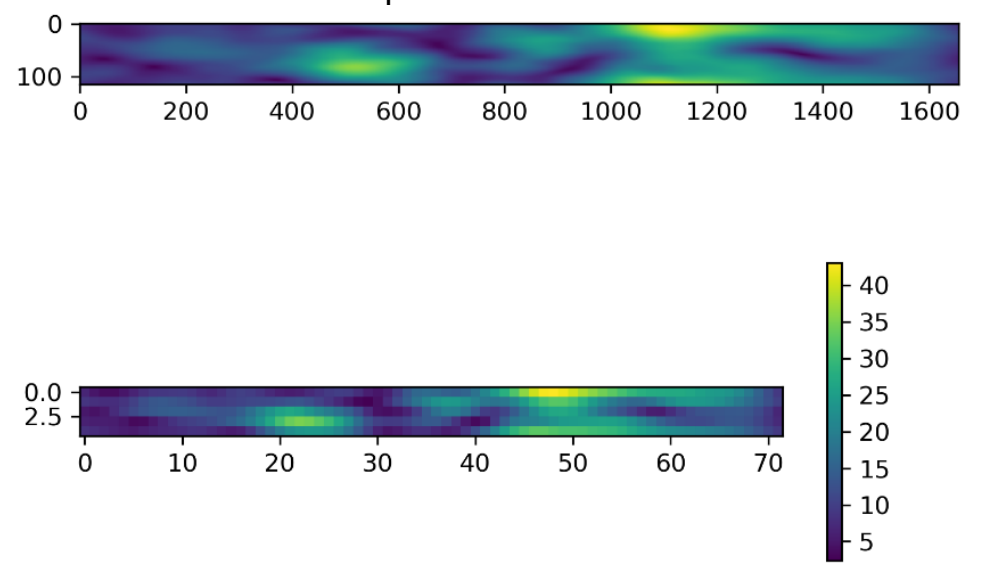

Slip distribution \#4
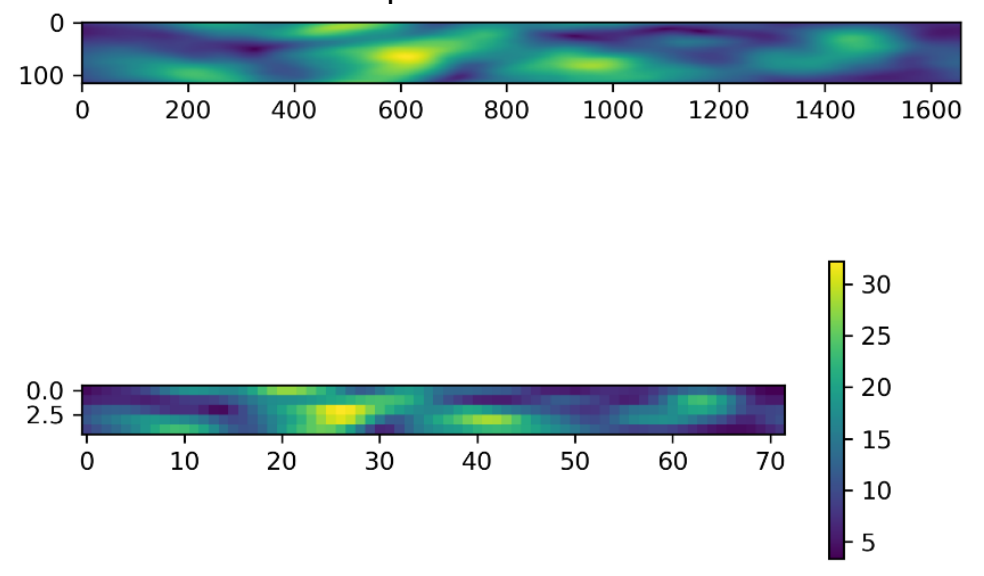

Figure B4: Continued. 
Slip distribution \#5
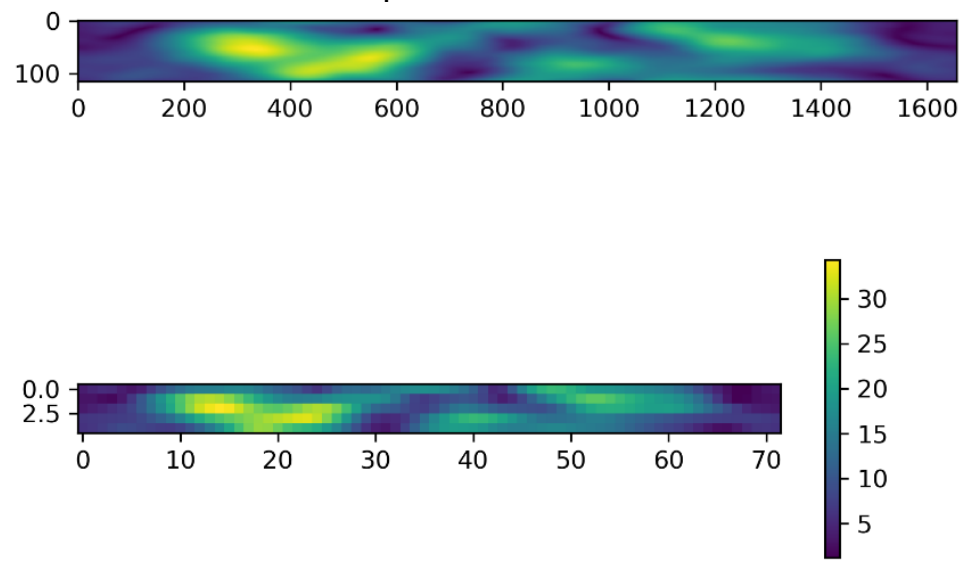

Slip distribution \#6
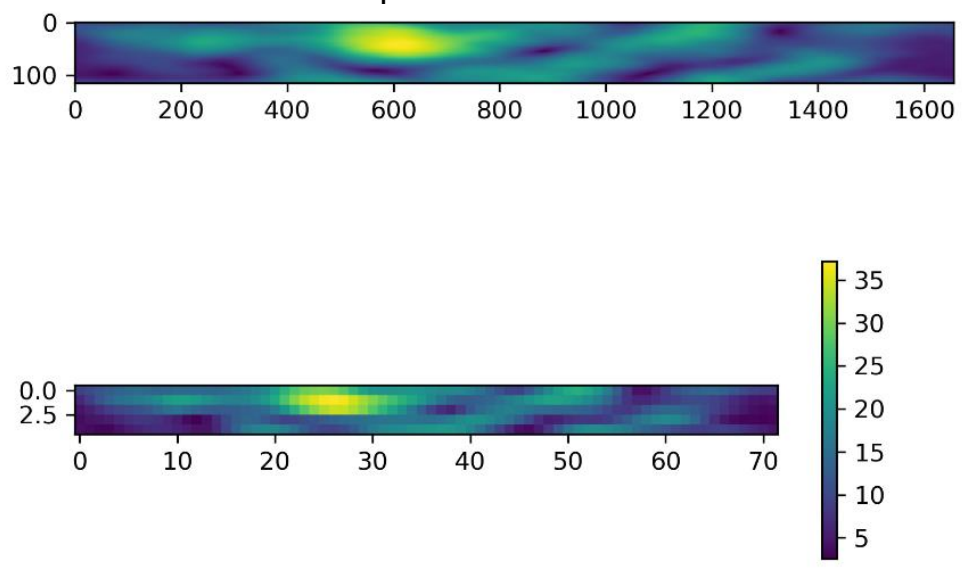

Figure B4: Continued. 

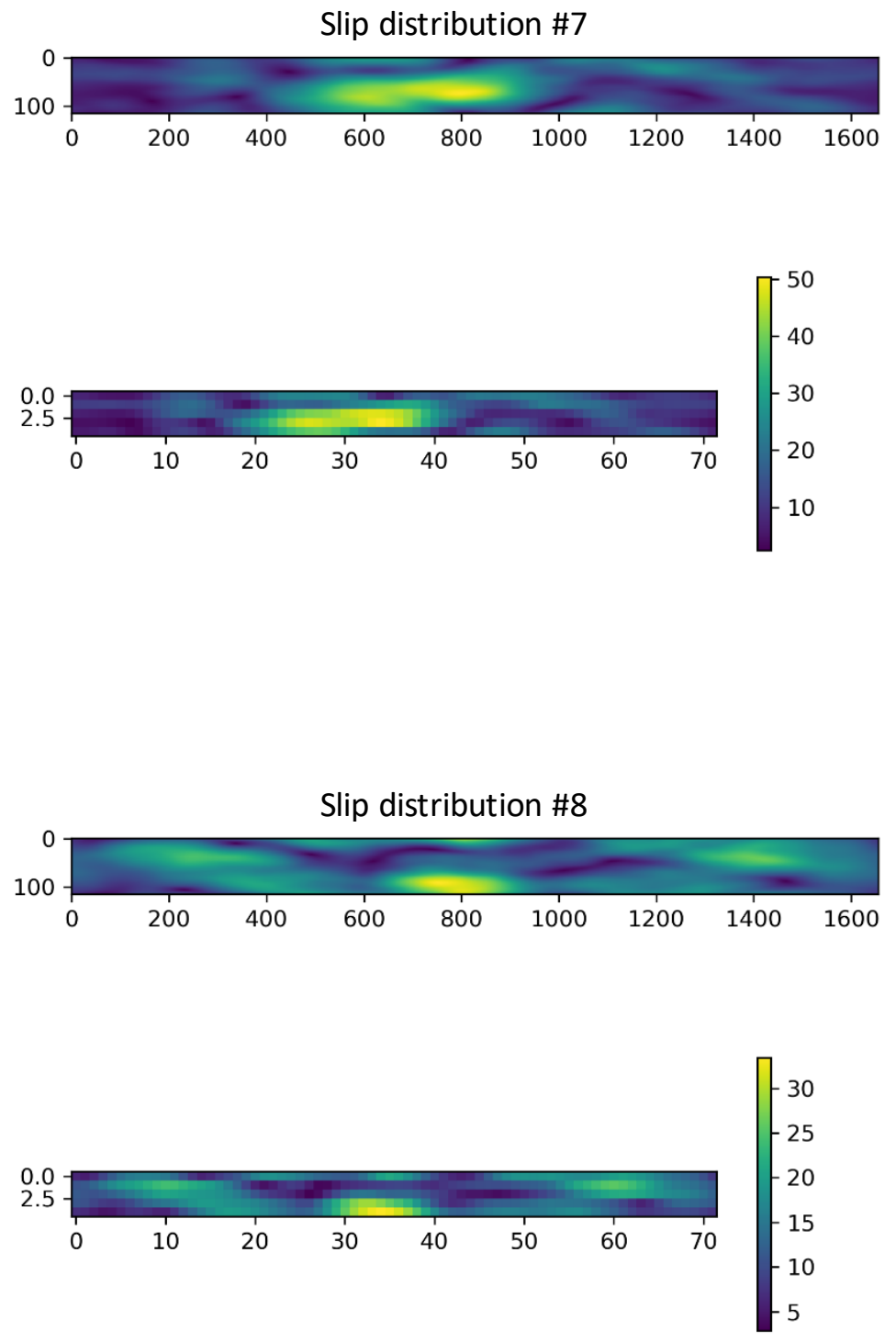

Figure B4: Continued. 

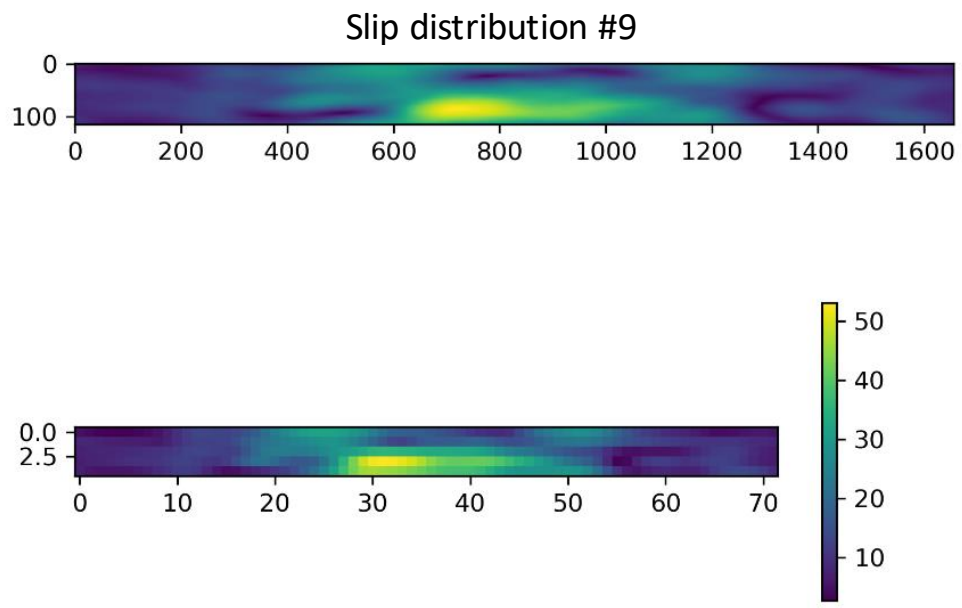

Slip distribution \#10
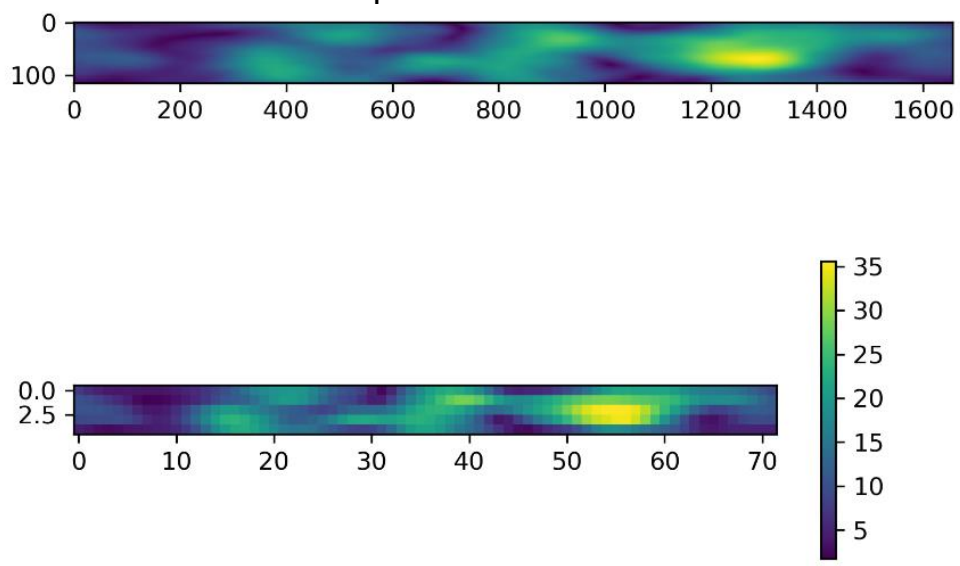

Figure B4: Continued. 

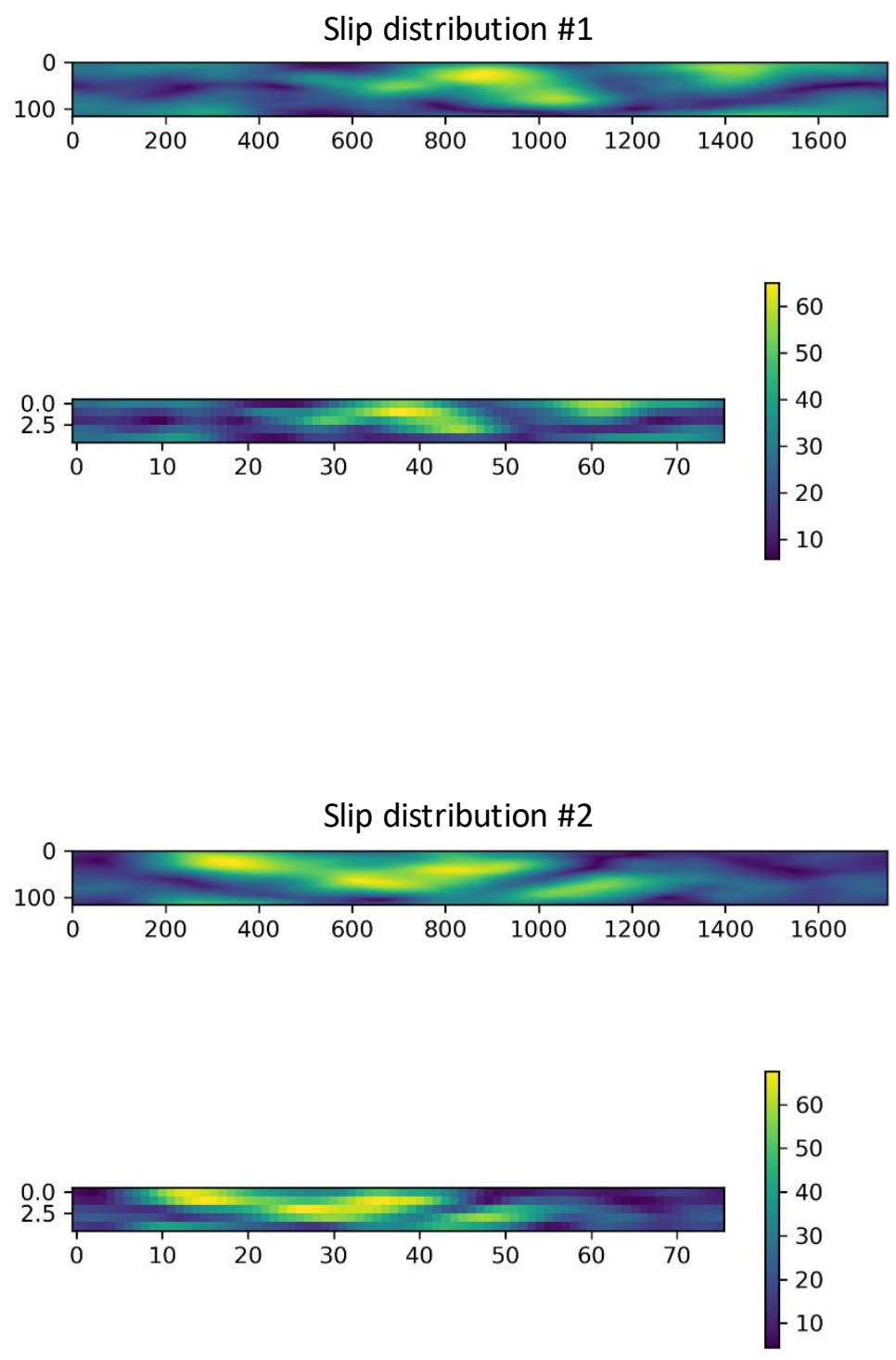

Figure B5: The ten $\mathrm{M}_{\mathrm{w}} 9.5$ stochastic variable slip distributions in planar view (top) and cross-sectional view (bottom) used to generate earthquake source models. Brighter colors correspond to greater slip. 

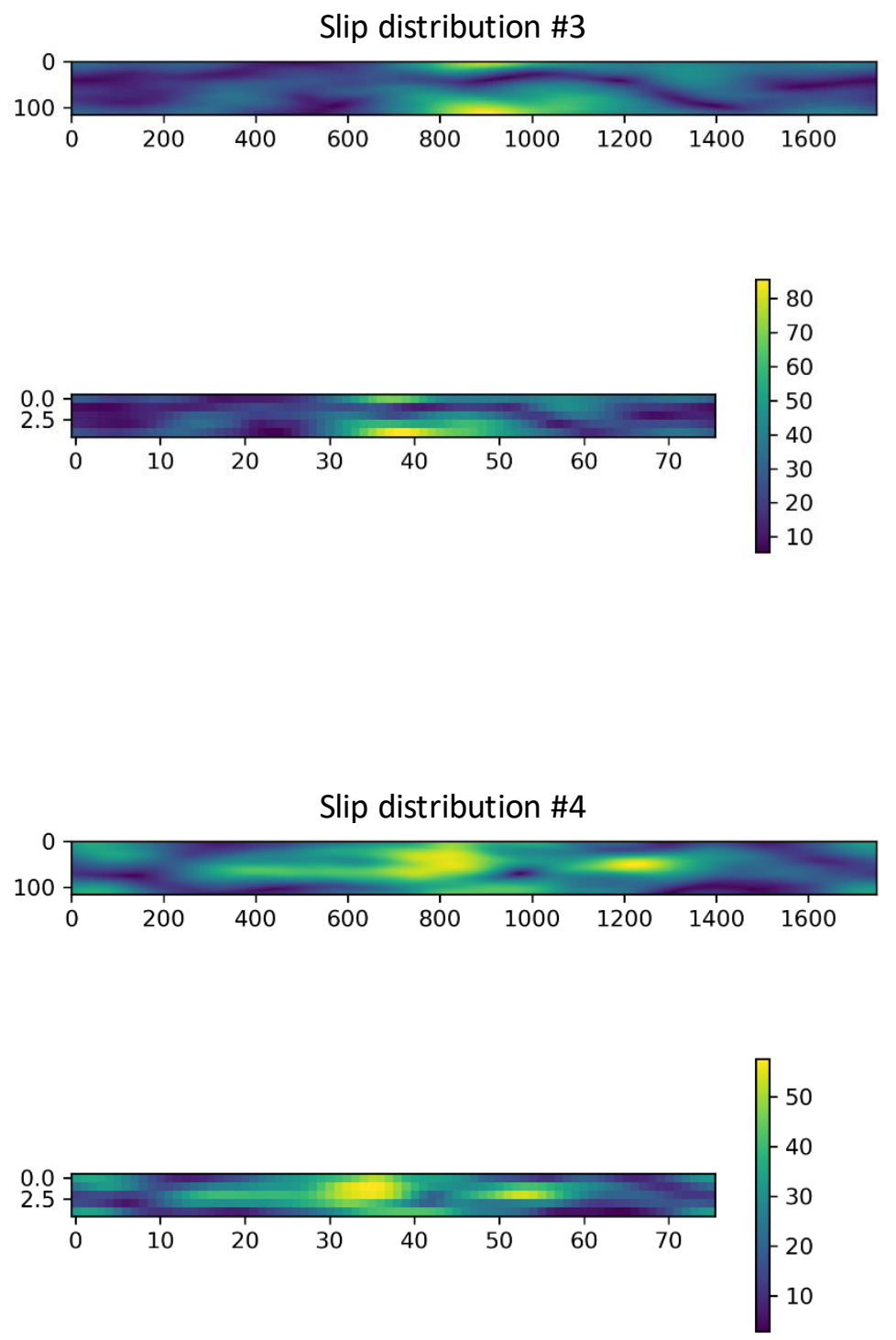

Figure B5: Continued. 

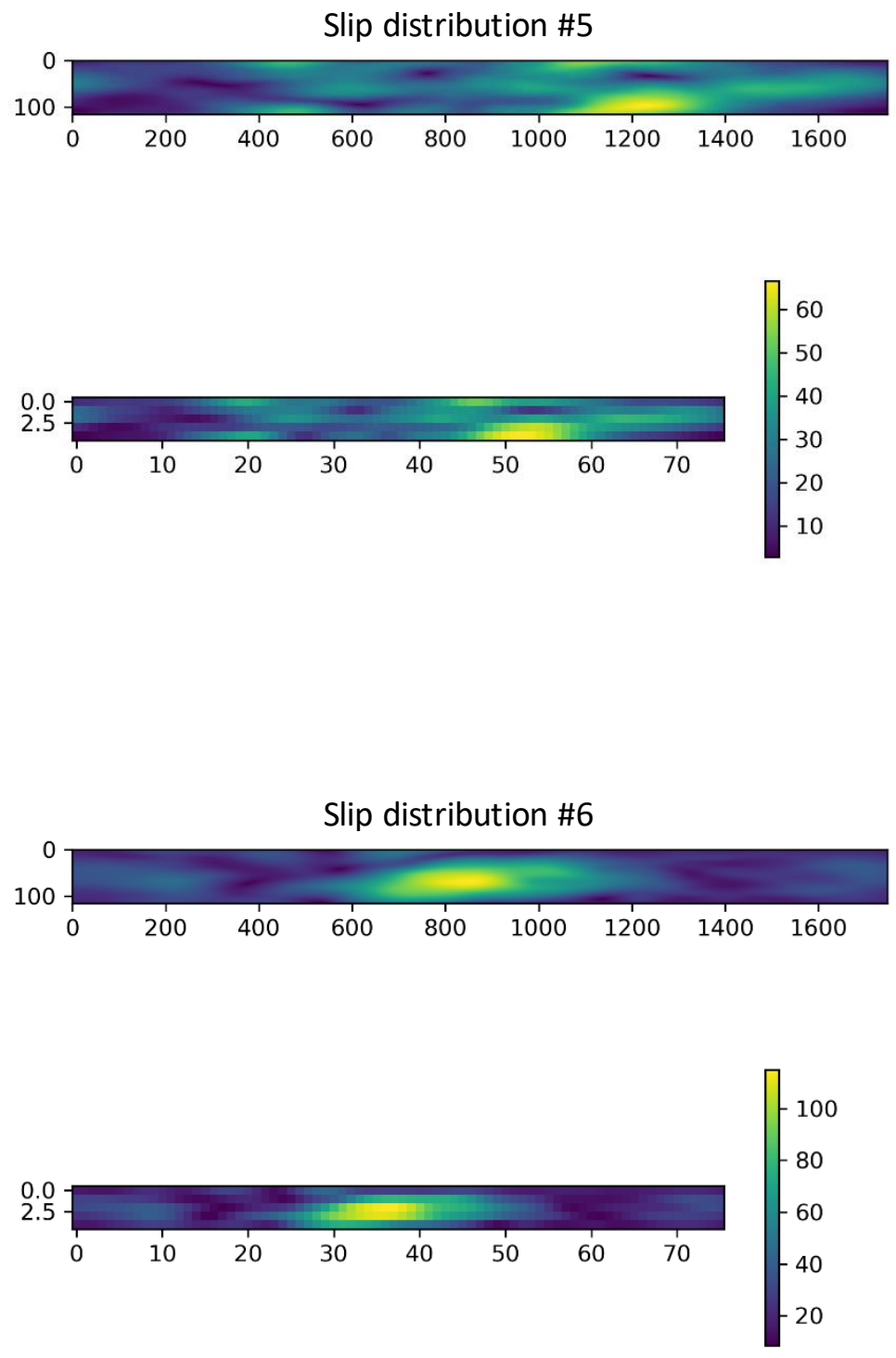

Figure B5: Continued. 

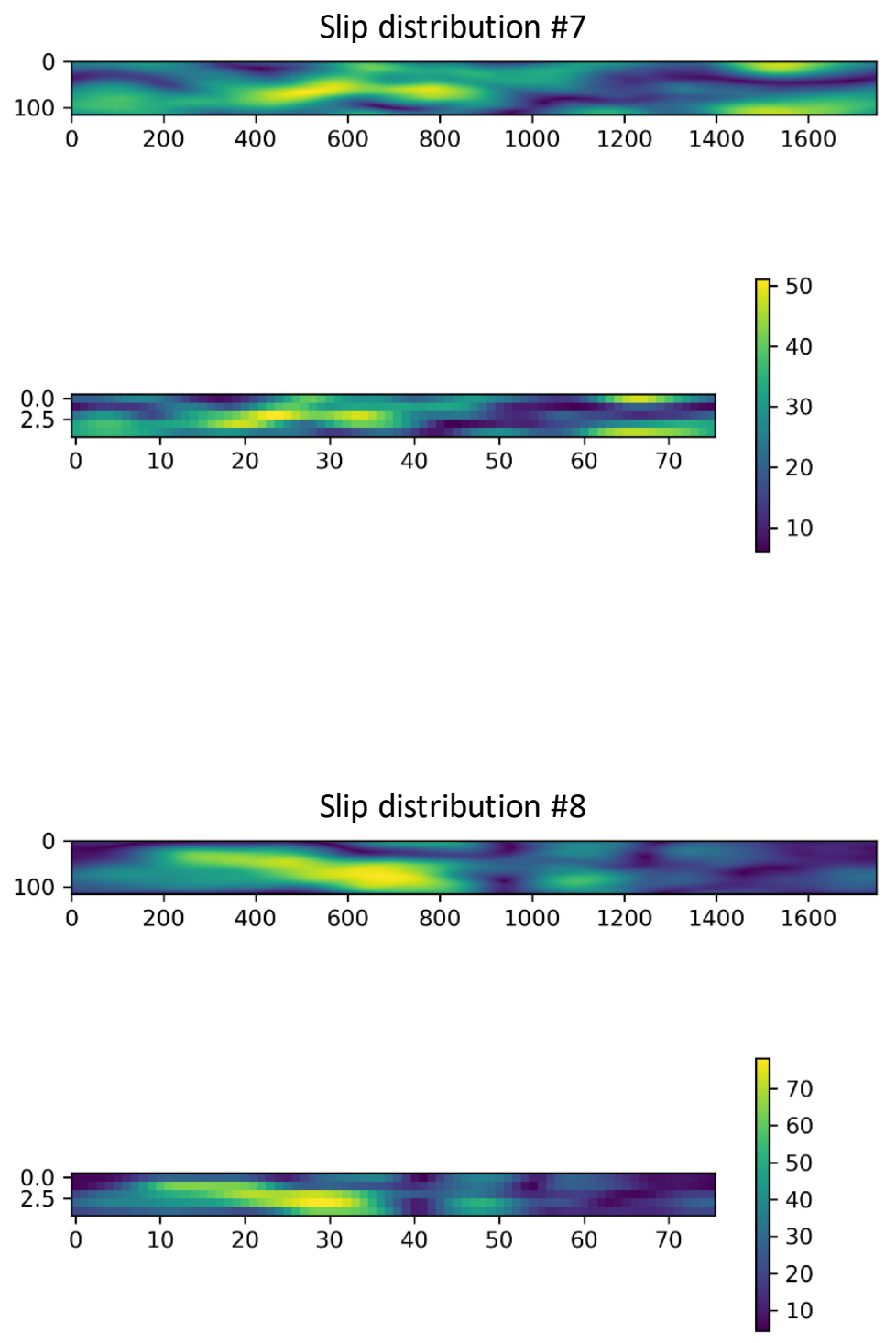

Figure B5: Continued. 

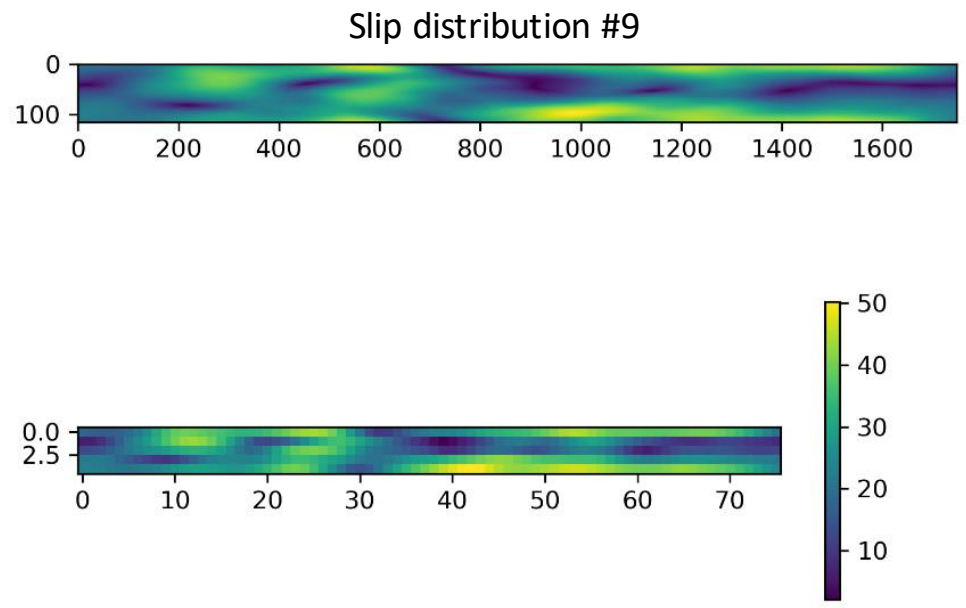

Slip distribution \#10
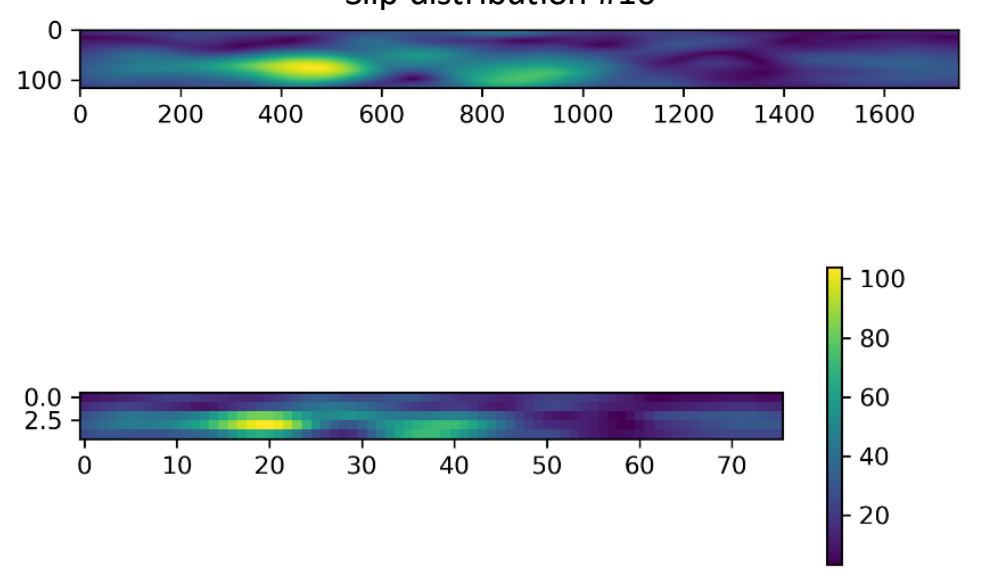

Figure B5: Continued 


\section{APPENDIX C \\ Setrun.py file for GeoClaw simulations}

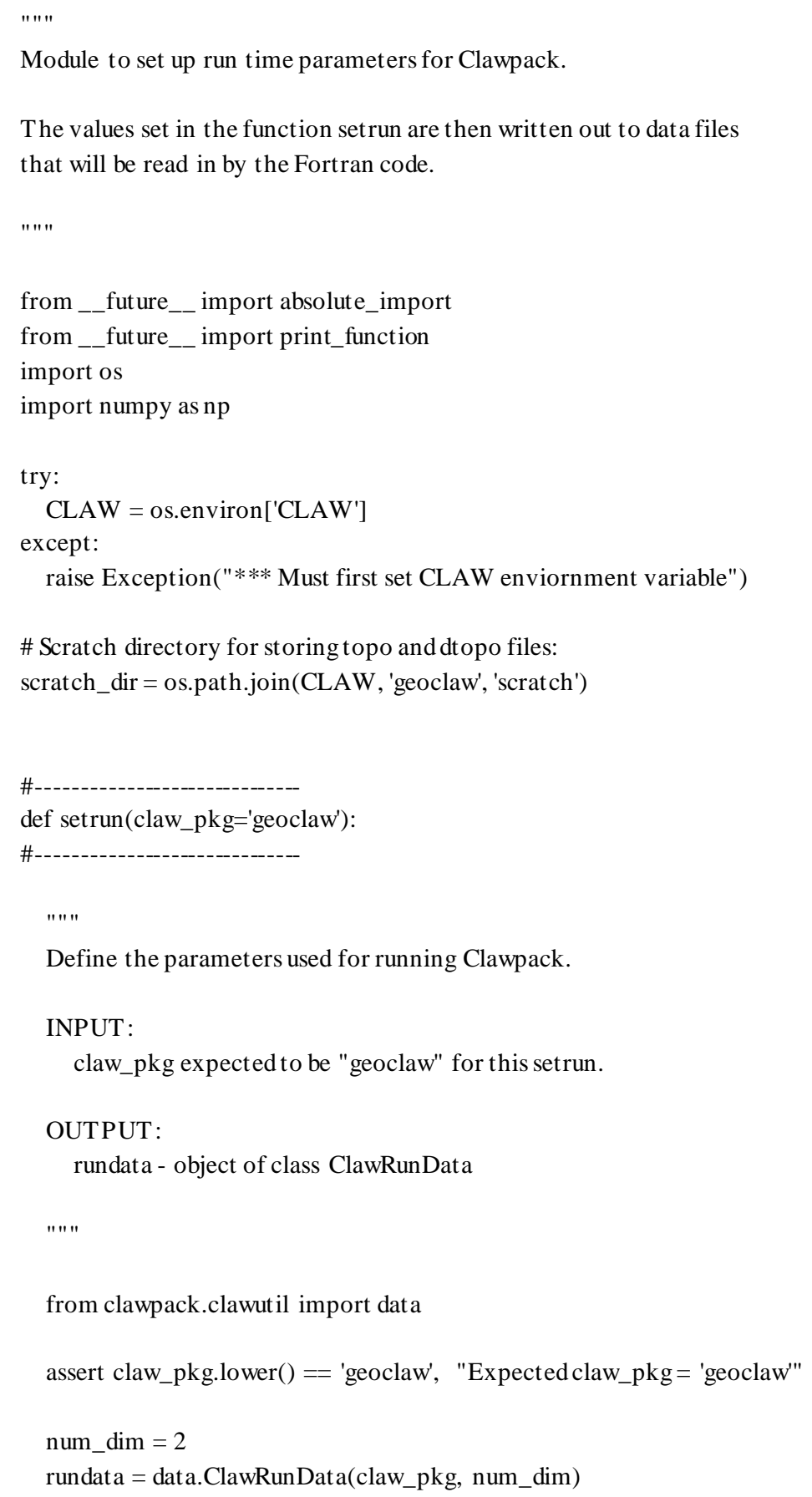




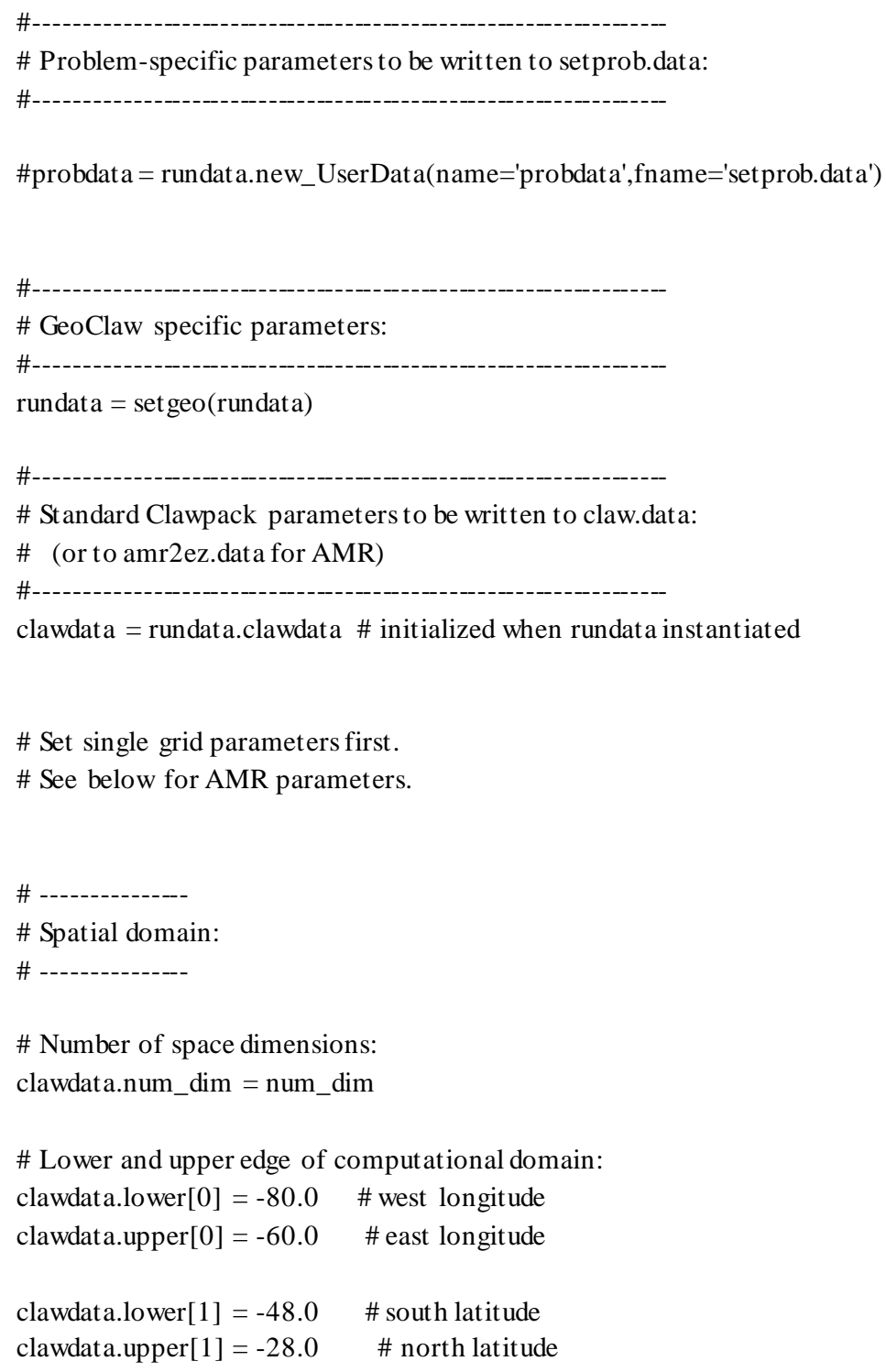

\# Number of grid cells: Coarsest grid

clawdata.num_cells[0] $=20$

clawdata.num_cells $[1]=20$

\# -

\# Size of system:

\# -------------- 
\# Number of equations in the system:

clawdata.num_eqn $=3$

\# Number of auxiliary variables in the aux array (initialized in setaux)

clawdata.num_aux $=3$

\# Index of aux array corresponding to capacity function, if there is one: clawdata.capa_index $=2$

$\#$

\# Initial time:

\# -------------

clawdata.t $0=0.0$

\# Restart from checkpoint file of a previous run?

\# If restarting, $\mathrm{t} 0$ above should be from original run, and the \# restart_file 'fort.chkNNNNN' specified below should be in \# the OUTDIR indicated in Makefile.

clawdata.restart $=$ False \# True to restart from prior results clawdata.restart_file = 'fort.chk00096' \# File to use for restart data

\# ------------

\# Output times:

\#---------------

\# Specify at what times the results should be written to fort.qfiles. \# Note that the time integration stops after the final output time. \# The solution at initial time t0 is always written in addition.

clawdata.output_style $=1$

if clawdata.output_style==1:

\# Output nout frames at equally spaced times up to tfinal:

clawdata.num_output_times $=24$

clawdata.tfinal $=4 * 3600$.

clawdata.output_t $0=$ True \# output at initial (or restart) time?

elif clawdata.output_style $==2$ :

\# Specify a list of output times.

clawdata.output_times $=[0.5,1.0]$

elif clawdata.output_style $==3$ :

\# Output every iout timesteps with a total of ntot time steps: clawdata.output_step_interval $=1$ 
clawdata.total_steps $=3$
clawdata.output_t $0=$ True

clawdata.output_format = 'ascii' \# 'ascii' or 'netcdf'

clawdata.output_q_components ='all' \# need all

clawdata.output_aux_components ='none' \# eta $=\mathrm{h}+\mathrm{B}$ is in $\mathrm{q}$

clawdata.output_aux_onlyonce $=$ False \# output aux arrays each frame

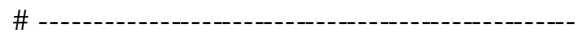

\# Verbosity of messages to screen during integration:

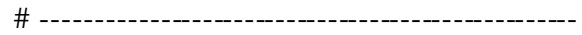

\# The current $\mathrm{t}$, dt, and cfl will be printed every time step

\# at AMR levels <= verbosity. Set verbosity $=0$ for no printing.

\# (E.g. verbosity $==2$ means print only on levels 1 and 2.)

clawdata.verbosity $=1$

\# --

\# Time stepping:

\# --------------

\# if dt_variable==1: variable time steps used based on cfl_desired,

\# if dt_variable==0: fixed time steps $\mathrm{dt}=\mathrm{dt}$ _initial will always be used. clawdata.dt_variable $=$ True

\# Initial time step for variable dt.

\# If dt_variable $==0$ then $\mathrm{dt}=\mathrm{dt} \_$initial for all steps:

clawdata.dt_initial $=0.2$

\# Max time step to be allowed if variable dt used:

clawdata.dt_max = 1 x 1099

\# Desired Courant number if variable dt used, and max to allow without \# retaking step with a smaller $\mathrm{dt}$ :

clawdata.cfl_desired $=0.75$

clawdata.cfl_max $=1.0$

\# Maximum number of time steps to allow between output times:

clawdata.steps_max $=5000$ 


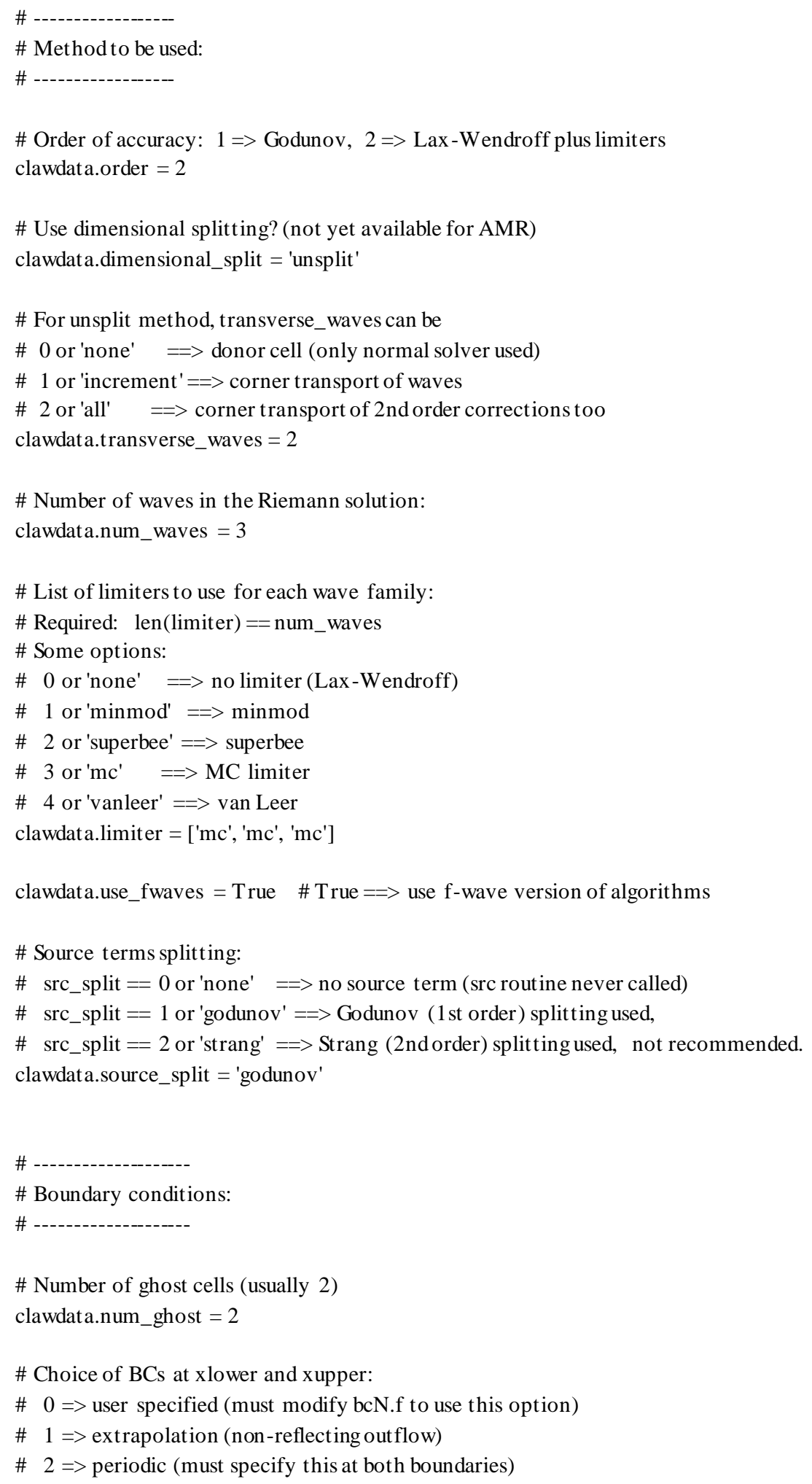


\# 3 => solid wall for systems where $\mathrm{q}(2)$ is normal velocity

clawdata.bc_lower[0] = 'extrap'
clawdata.bc_upper[0] = 'extrap'
clawdata.bc_lower[1] = 'extrap'
clawdata.bc_upper[1] = 'extrap'

\#

\# Checkpointing:

\# --------------

\# Specify when checkpoint files should be created that can be \# used to restart a computation.

clawdata.checkpt_style $=0$

if clawdata.checkpt_style $==0$ :

\# Do not checkpoint at all

pass

elif clawdata.checkpt_style $==1$ :

\# Checkpoint only at tfinal.

pass

elif clawdata.checkpt_style $==2$ :

\# Specify a list of checkpoint times.

clawdata.checkpt_times $=[0.1,0.15]$

elif clawdata.checkpt_style $==3$ :

\# Checkpoint every checkpt_interval timesteps (on Level 1)

\# and at the final time.

clawdata.checkpt_interval $=5$

\# ----------------

\# AMR parameters:

\# --------------

amrdata $=$ rundat $a \cdot$ amrdat $\mathrm{a}$

\# max number of refinement levels:

amrdata.amr_levels_max $=5$

\# List of refinement ratios at each level (length at least mxnest-1)

amrdata.refinement_ratios_x $=[3,5,4,4]$

amrdata.refinement_ratios_y $=[3,5,4,4]$

amrdata.refinement_ratios_t $=[1,1,1,1]$ 
\# Specify type of each aux variable in amrdata.auxtype.

\# This must be a list of length maux, each element of which is one of:

\# 'center', 'capacity', 'xleft', or 'yleft' (see documentation).

amrdata.aux_type $=[$ 'center','capacity','yleft']

\# Flag using refinement routine flag2refine rather than richardson error amrdata.flag_richardson $=$ False \# use Richardson?

amrdata.flag2refine $=$ True

\# steps to take on each level L between regriddings of level $\mathrm{L}+1$ :

amrdata.regrid_interval $=3$

\# width of buffer zone around flagged points:

\# (typically the same as regrid_interval so waves don't escape):

amrdata.regrid_buffer_width $=2$

\# clustering alg. cutoff for (\# flagged pts) / (total \# of cells refined)

\# (closer to $1.0=>$ more small grids may be needed to cover flagged cells)

amrdata.clustering_cutoff $=0.700000$

\# print info about each regridding up to this level:

amrdata.verbosity_regrid $=0$

\# ----- For developers -----

\# Toggle debugging print statements:

amrdata.dprint $=$ False $\quad \#$ print domain flags

amrdata.eprint $=$ False $\quad \#$ print err est flags

amrdata.edebug $=$ False $\quad \#$ even more err est flags

amrdata.gprint $=$ False $\quad$ \# grid bisection/clustering

amrdata.nprint $=$ False $\quad$ \# proper nesting output

amrdata.pprint $=$ False $\quad \#$ proj. of tagged points

amrdata.rprint $=$ False $\quad$ \# print regridding summary

amrdata.sprint $=$ False $\quad \#$ space/memory output

amrdata.tprint $=$ True \# time step reporting each level

amrdata.uprint $=$ False $\quad \#$ update/upbnd reporting

\# More AMR parameters can be set -- see the defaults in pyclaw/data.py

\# -

\# Regions:

\# -

rundata.regiondata.regions $=$ []

\# to specify regions of refinement append lines of the form

\# [minlevel,maxlevel,t 1,t2,x1,x2,y1,y2] 
rundata.regiondata.regions.append([5,5,0,1e10,-71.64871767,-71.58226600,-33.05920767,-

33.01545867])\#Valpraiso, 7

rundata.regiondata.regions.append([5,5,0,1e10,-72.44166167,-72.19453733,-35.33298667,-

35.09301133])\#Constitucion, 8

rundata.regiondata.regions.append([5,5,0,1e10,-73.16999133,-72.92790667,-36.75318200,-

36.52120900])\#Concepcion,9

rundata.regiondata.regions. append([5,5,0,1e10,-73.44002000,-73.13827667,-37.25091467,-

37.01934833])\#Arauco, 10

rundata.regiondata.regions.append([5,5,0,1e10,-73.55692967,-73.44502933,-38.09658800,-37.88187133])\# North of

Tirua, 11

rundata.regiondata.regions.append([5,5,0,1e10,-73.51092067,-73.46477000,-38.26197233,-

38.21710700])\#Quidico, 12

rundata.regiondata.regions.append([5,5,0,1e10,-73.56257800,-73.50366167,-38.361 13267,-38.31139533])\#Tirua,13 rundata.regiondata.regions.append([5,5,0,1e10,-73.88406567,-73.85073233,-38.39548133,-38.36214800])\#Isla

Mocha, 14

rundata.regiondata.regions.append([5,5,0,1e10,-73.48295400,-73.36848367,-38.80198667,-38.70124833])\#Puerto

Saavedra, 15

rundata.regiondata.regions.append([5,5,0,1e10,-73.30326267,-73.21113467,-39.44663867,--

39.11084433])\#Queule, 16

rundata.regiondata.regions. append([5,5,0,1 e10,-73.61224667,-73.38245400,-39.96052567,-

39.86720733])\#Valdivia, 17

rundata.regiondata.regions. append([5,5,0,1e10,-73.75973333,-73.72640000,-40.55210467,-

40.51877133])\#Pucotrihue, 18

rundata.regiondata.regions.append([5,5,0,1 e10,-72.97221633,-72.93888300,-41.50269067,-41.46935733])\#Puerto

Montt, 19

rundata.regiondata.regions.append([5,5,0,1e10,-73.74162267,-73.70828933,-41.64843267,-

41.61509933])\#Maullin,20

rundata.regiondata.regions.append([5,5,0,1e10,-74.06498367,-73.99647933,-42.07668667,-41.87099900])\#North

Chiloe ,21

rundata.regiondata.regions. append([5,5,0,1 e10,-74.21346667,-74.11026933,-42.87939867,-42.61832133])\#South

Chiloe, 22

rundata.regiondata.regions.append([5,5,0,1e10,-72.72587467,-72.69254133,-44.74725567,-44.71392233])\#Puerto

Aysen, 23

rundata.regiondata.regions.append([5,5,0,1e10,-72.85892967,-72.82559633,-45.41924367,-45.38591033])\#Puerto

Aysen, 24

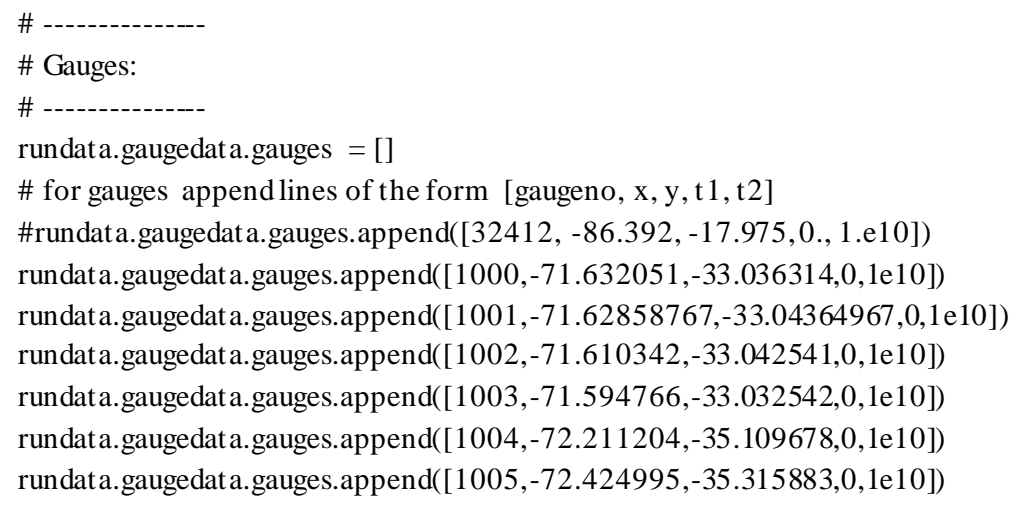


rundata.gaugedata.gauges.append([1006,-72.41962833,-35.31215333,0,1e10])

rundata.gaugedata.gauges.append([1008,-72.94457333,-36.53787567,0,1e10])

rundata.gaugedata.gauges.append([1009,-72.967076,-36.630238,0,1e10])

rundata.gaugedat a.gauges.append([1010,-73.056865,-36.63735,0,1e10])

rundata.gaugedata.gauges.append([1011,-73.10445,-36.72057333,0,1e10])

rundata.gaugedata.gauges.append([1012,-73.055614,-36.73054133,0,1e10])

rundat a.gaugedat a.gauges.append([1013,-73.15707467,-36.72637467,0,1e10])

rundata.gaugedat a.gauges.append([1014,-72.99914033,-36.72783767,0,1e10])

rundata.gaugedata.gauges.append([1022,-73.15494333,-37.036015,0,1e10])

rundata.gaugedata.gauges.append([1023,-73.42335333,-37.234248,0,1e10])

rundata.gaugedata.gauges.append([1024,-73.540263,-37.898538,0,1e10])

rundata.gaugedata.gauges.append([1025,-73.483688,-37.997792,0,1e10])

rundata.gaugedata.gauges.append([1026,-73.480821,-38.011591,0,1e10])

rundata.gaugedata.gauges.append([1027,-73.461696,-38.084088,0,1e10])

rundata.gaugedata.gauges.append([1028,-73.47727,-38.23294033,0,1e10])

rundata.gaugedata.gauges.append([1029,-73.492902,-38.24236567,0,1e10])

rundat a.gaugedat a.gauges.append([1052,-73.49333,-38.24530567,0,1e10])

rundata.gaugedata.gauges.append([1053,-73.53907833,-38.328062,0,1e10])

rundata.gaugedata.gauges.append([1054,-73.54591133,-38.344466,0,1e10])

rundata.gaugedata.gauges.append([1055,-73.870524,-38.37881467,0,1e10])

rundata.gaugedata.gauges.append([1056,-73.46712067,-38.717915,0,1e10])

rundata.gaugedata.gauges.append([1058,-73.42258433,-38.78532,0,1e10])

rundata.gaugedata.gauges.append([1059,-73.286596,-39.127511,0,1e10])

rundata.gaugedata.gauges.append([1060,-73.23602633,-39.281829,0,1e10])

rundata.gaugedata.gauges.append([1061,-73.22780133,-39.358523,0,1e10])

rundata.gaugedata.gauges.append([1062,-73.246352,-39.427001,0,1e10])

rundat a.gaugedat a.gauges.append([1066,-73.41764867,-39.883874,0,1e10])

rundata.gaugedat a.gauges.append([1067,-73.39912067,-39.89045,0,1e10])

rundata.gaugedata.gauges.append([1068,-73.59558,-39.943859,0,1e10])

rundata.gaugedata.gauges.append([1069,-73.74306667,-40.535438,0,1e10])

rundata.gaugedata.gauges.append([1070,-72.95221633,-41.486024,0,1e10])

rundata.gaugedata.gauges.append([1072,-73.724956,-41.631766,0,1e10])

rundata.gaugedata.gauges.append([1100,-74.01731267,-41.88784467,0,1e10])

rundata.gaugedat a.gauges.append([1101,-74.048317,-42.06002,0,1e10])

rundata.gaugedata.gauges.append([1102,-74.126936,-42.634988,0,1e10])

rundata.gaugedat a.gauges.append([1103,-74.1968,-42.862732,0,1e10])

rundata.gaugedata.gauges.append([1104,-72.709208,-44.72975567,0,1e10])

rundata.gaugedata.gauges.append([1105,-72.842263,-45.402577,0,1e10])

return rundata

\# end of function setrun

\#

\#-

def setgeo(rundata):

\#------------

" " "

Set GeoClaw specific runtime parameters.

For documentation see .... 


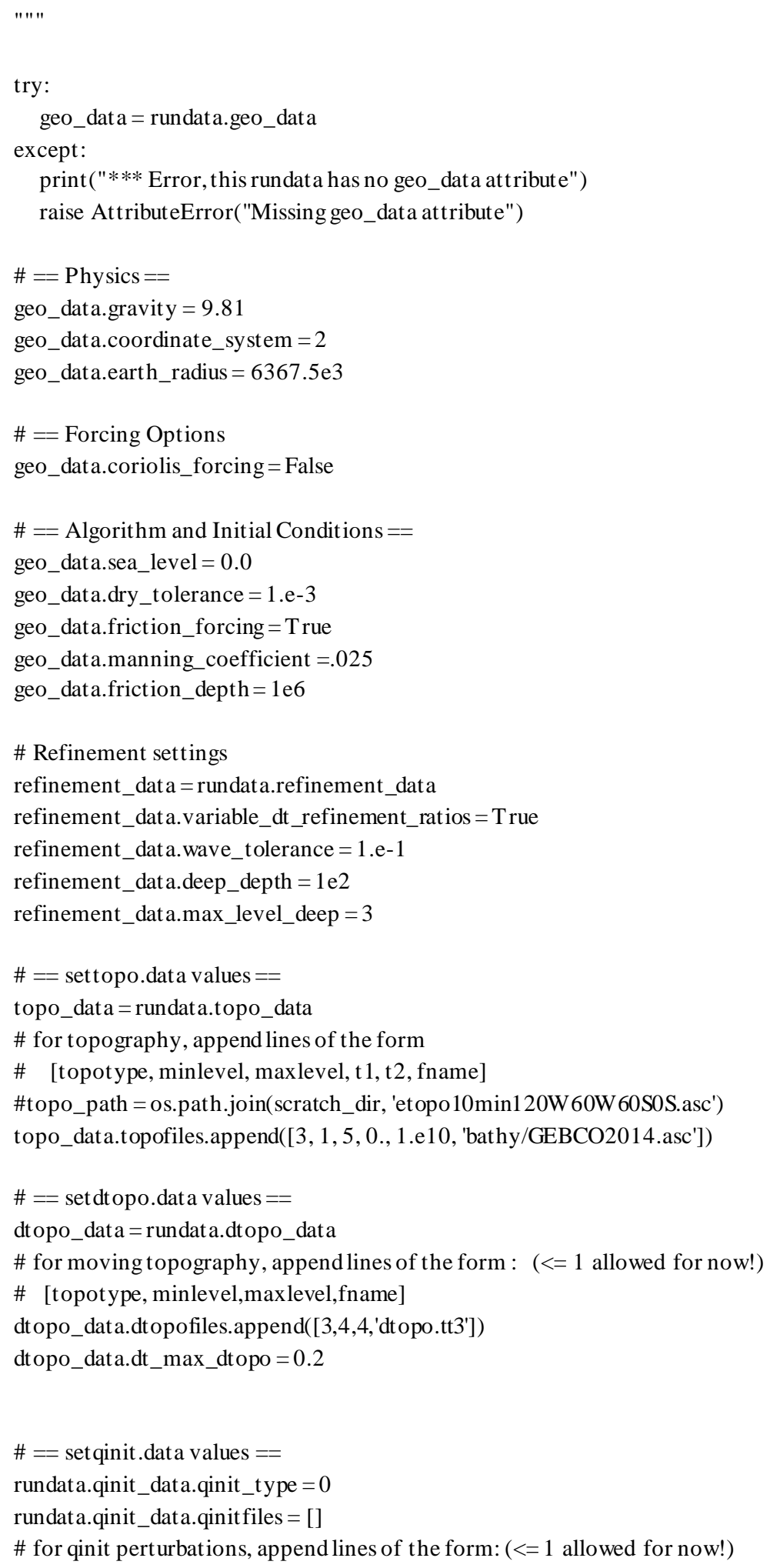


\# [minlev, maxlev, fname]

\# == setfixedgrids.data values $==$

fixed_grids = rundata.fixed_grid_data

\# for fixed grids append lines of the form

\# [t 1,t2,nout put, $\mathrm{x} 1, \mathrm{x} 2, \mathrm{y} 1, \mathrm{y} 2, \mathrm{x}$ points,ypoints, 1

\# ioutarrivaltimes,ioutsurfacemax ]

return rundata

\# end of function setgeo

\# ----------------------

if __name__=='__main__':

\# Set up run-time parameters and write all data files.

import sys

rundata $=\operatorname{setrun}(* \operatorname{sys} . \operatorname{argv}[1:])$

rundata.write() 


\section{APPENDIXD}

Tide gauge observations for AIC analysis

Table D1: The simulated tide gauges corresponding to tsunami observations used in the 1570 AIC analysis

\begin{tabular}{|c|c|c|c|c|c|c|c|c|c|c|}
\hline $\begin{array}{c}\text { Gauge } \\
\text { number }\end{array}$ & $\begin{array}{l}\text { Set run } \\
\text { longitude }\end{array}$ & $\begin{array}{l}\text { Set run } \\
\text { latitude }\end{array}$ & $\begin{array}{c}\text { Original } \\
\text { longitude }\end{array}$ & $\begin{array}{l}\text { Original } \\
\text { latitude }\end{array}$ & Type & $\begin{array}{c}\text { Inferred } \\
\text { min } \\
\text { observed } \\
\text { height }\end{array}$ & $\begin{array}{c}\text { Inferred } \\
\text { max } \\
\text { observed } \\
\text { height }\end{array}$ & $\begin{array}{l}\text { AVG } \\
\text { Height }\end{array}$ & $\begin{array}{c}\text { Standev } \\
\text { of } \\
\text { inferred } \\
\text { height }\end{array}$ & $\begin{array}{c}\text { Weighted } \\
\text { percentage } \\
\text { based on } \\
\text { standev }\end{array}$ \\
\hline 1014 & 72.99914 & 36.72784 & 72.99081 & 36.73617 & Observed & 4 & 5 & 4.5 & 0.5 & 2.00 \\
\hline 1015 & 73.16522 & 36.77093 & 73.17249 & 36.76566 & Inferred & 3 & 5 & 4 & 1 & 1.00 \\
\hline 1054 & 73.54591 & 38.34447 & $73 . \overline{-}+\overline{8} 758$ & 38.34447 & Inferred & 2 & 5 & 3.5 & 1.5 & 0.67 \\
\hline
\end{tabular}


Table D2: The simulated tide gauges corresponding to tsunami observations used in the 1575 AIC analysis

\begin{tabular}{|c|c|c|c|c|c|c|c|c|c|c|}
\hline $\begin{array}{l}\text { Gauge } \\
\text { number }\end{array}$ & $\begin{array}{l}\text { Set run } \\
\text { longitude }\end{array}$ & $\begin{array}{l}\text { Set run } \\
\text { latitude }\end{array}$ & $\begin{array}{c}\text { Original } \\
\text { longitude }\end{array}$ & $\begin{array}{l}\text { Original } \\
\text { latitude }\end{array}$ & Type & $\begin{array}{l}\text { Inferred } \\
\text { min } \\
\text { observed } \\
\text { height }\end{array}$ & $\begin{array}{c}\text { Inferred } \\
\text { max } \\
\text { observed } \\
\text { height }\end{array}$ & $\begin{array}{l}\text { AVG } \\
\text { Height }\end{array}$ & $\begin{array}{l}\text { Standev } \\
\text { of } \\
\text { inferred } \\
\text { height }\end{array}$ & $\begin{array}{c}\text { Weighted } \\
\text { percentage } \\
\text { based on } \\
\text { standev }\end{array}$ \\
\hline 1014 & 72.99914 & 36.72784 & 72.99081 & 36.73617 & Inferred & 3 & 5 & 4 & 1 & 1.00 \\
\hline 1015 & 73.16522 & 36.77093 & 73.17249 & 36.76566 & Inferred & 3 & 5 & 4 & 1 & 1.00 \\
\hline 1024 & 73.54026 & $\begin{array}{c}- \\
37.89854 \\
\end{array}$ & 73.54026 & $\begin{array}{c}- \\
37.89854 \\
\end{array}$ & Inferred & 4 & 6 & 5 & 1 & 1.00 \\
\hline 1053 & 73.53908 & $\begin{array}{c}- \\
38.32806 \\
\end{array}$ & 73.53700 & 38.32806 & Inferred & 2 & 9 & 5.5 & 3.5 & 0.29 \\
\hline 1054 & 73.54591 & 38.34447 & 73.48758 & 38.34447 & Inferred & 2 & 9 & 5.5 & 3.5 & 0.29 \\
\hline 1056 & $\begin{array}{c}- \\
73.46712 \\
\end{array}$ & $\begin{array}{c}- \\
38.71792 \\
\end{array}$ & 73.47045 & $\begin{array}{c}- \\
38.71792 \\
\end{array}$ & Inferred & 4 & 12 & 8 & 4 & 0.25 \\
\hline 1058 & 73.42258 & $\begin{array}{c}- \\
38.78532 \\
\end{array}$ & 73.42675 & $\begin{array}{c}- \\
38.78532 \\
\end{array}$ & Inferred & 4 & 12 & 8 & 4 & 0.25 \\
\hline 1066 & $\begin{array}{c}- \\
73.41765 \\
\end{array}$ & $\begin{array}{c}- \\
39.88387 \\
\end{array}$ & $\begin{array}{c}- \\
73.42598 \\
\end{array}$ & $\begin{array}{c}- \\
39.88387 \\
\end{array}$ & Inferred & 3 & 10.5 & 6.75 & 3.75 & 0.27 \\
\hline 1072 & 73.72496 & 41.63177 & 73.67817 & 41.57341 & Inferred & 4.1 & 10 & 7.05 & 2.95 & 0.34 \\
\hline 1100 & 74.01731 & 41.88784 & 74.00065 & 41.84618 & Inferred & 4 & 6 & 5 & 1 & 1.00 \\
\hline 1101 & 74.04832 & 42.06002 & 74.04832 & 42.06002 & Inferred & 7 & 10 & 8.5 & 1.5 & 0.67 \\
\hline 1102 & $\begin{array}{c}- \\
74.12694 \\
\end{array}$ & $\begin{array}{c}- \\
42.63499 \\
\end{array}$ & $\begin{array}{c}- \\
74.12694 \\
\end{array}$ & $\begin{array}{c}- \\
42.63499 \\
\end{array}$ & Inferred & 5 & 7 & 6 & 1 & 1.00 \\
\hline
\end{tabular}


Table D3: The simulated tide gauge corresponding to tsunami observations used in the 1657 AIC analysis

\begin{tabular}{|c|c|c|c|c|c|c|c|c|c|c|}
\hline $\begin{array}{l}\text { Gauge } \\
\text { number }\end{array}$ & $\begin{array}{l}\text { Set run } \\
\text { longitude }\end{array}$ & $\begin{array}{l}\text { Set run } \\
\text { latitude }\end{array}$ & $\begin{array}{c}\text { Original } \\
\text { longitude }\end{array}$ & $\begin{array}{l}\text { Original } \\
\text { latitude }\end{array}$ & Type & $\begin{array}{l}\text { Inferred } \\
\text { min } \\
\text { observed } \\
\text { height }\end{array}$ & $\begin{array}{c}\text { Inferred } \\
\text { max } \\
\text { observed } \\
\text { height }\end{array}$ & $\begin{array}{l}\text { AVG } \\
\text { Height }\end{array}$ & $\begin{array}{c}\text { Standev } \\
\text { of } \\
\text { inferred } \\
\text { height }\end{array}$ & $\begin{array}{c}\text { Weighted } \\
\text { percentage } \\
\text { based on } \\
\text { standev }\end{array}$ \\
\hline 1014 & 72.99914 & 36.72784 & 72.99081 & 36.73617 & observed & 7.5 & 8.5 & 8 & 0.5 & 2.00 \\
\hline
\end{tabular}

1730

Table D4: The simulated tide gauges corresponding to tsunami observations used in the 1730 AIC analysis

\begin{tabular}{|c|c|c|c|c|c|c|c|c|c|c|}
\hline $\begin{array}{c}\text { Gauge } \\
\text { number }\end{array}$ & $\begin{array}{l}\text { Set run } \\
\text { longitude }\end{array}$ & $\begin{array}{l}\text { Set run } \\
\text { latitude }\end{array}$ & $\begin{array}{c}\text { Original } \\
\text { longitude }\end{array}$ & $\begin{array}{l}\text { Original } \\
\text { latitude }\end{array}$ & Type & $\begin{array}{l}\text { Inferred } \\
\text { min } \\
\text { observed } \\
\text { height }\end{array}$ & $\begin{array}{l}\text { Inferred } \\
\text { max } \\
\text { observed } \\
\text { height }\end{array}$ & $\begin{array}{l}\text { AVG } \\
\text { Height }\end{array}$ & $\begin{array}{l}\text { Standev } \\
\text { of } \\
\text { inferred } \\
\text { height }\end{array}$ & $\begin{array}{l}\text { Weighted } \\
\text { percentage } \\
\text { based on } \\
\text { standev }\end{array}$ \\
\hline 1000 & 71.63205 & 33.03631 & -71.63205 & $\begin{array}{c}- \\
33.03631 \\
\end{array}$ & Observed & 8.5 & 9.5 & 9 & 0.5 & 2.00 \\
\hline 1001 & 71.62859 & 33.04365 & -71.62942 & 33.03948 & Observed & 9.5 & 10.5 & 10 & 0.5 & 2.00 \\
\hline 1003 & 71.59477 & 33.03254 & -71.60727 & 33.04879 & Observed & 8.5 & 9.5 & 9 & 0.5 & 2.00 \\
\hline 1011 & 73.10445 & 36.72057 & -73.10445 & 36.72474 & Inferred & 6 & 8 & 7 & 1 & 1.00 \\
\hline 1014 & 72.99914 & 36.72784 & -72.99081 & 36.73617 & Observed & 7.5 & 8.5 & 8 & 0.5 & 2.00 \\
\hline 1066 & 73.41765 & 39.88387 & -73.42598 & 39.88387 & Inferred & 5 & 8 & 6.5 & 1.5 & 0.67 \\
\hline 1106 & $71 . \overline{-} 9623$ & $32 . \overline{7} 5048$ & $71 . \overline{4}^{-} 55166$ & 32.75595 & Inferred & 8 & 12 & 10 & 2 & 0.50 \\
\hline
\end{tabular}


Table D5: The simulated tide gauges corresponding to tsunami observations used in the 1751 AIC analysis

\begin{tabular}{|c|c|c|c|c|c|c|c|c|c|c|}
\hline $\begin{array}{l}\text { Gauge } \\
\text { number }\end{array}$ & $\begin{array}{l}\text { Set run } \\
\text { longitude }\end{array}$ & $\begin{array}{l}\text { Set run } \\
\text { latitude }\end{array}$ & $\begin{array}{c}\text { Original } \\
\text { longitude }\end{array}$ & $\begin{array}{l}\text { Original } \\
\text { latitude }\end{array}$ & Type & $\begin{array}{c}\text { Inferred } \\
\text { min } \\
\text { observed } \\
\text { height }\end{array}$ & $\begin{array}{c}\text { Inferred } \\
\text { max } \\
\text { observed } \\
\text { height }\end{array}$ & $\begin{array}{c}\text { AVG } \\
\text { Height }\end{array}$ & $\begin{array}{l}\text { Standev } \\
\text { of } \\
\text { inferred } \\
\text { height }\end{array}$ & $\begin{array}{c}\text { Weighted } \\
\text { percentage } \\
\text { based on } \\
\text { standev }\end{array}$ \\
\hline 1008 & 72.94457 & 36.53788 & 72.93624 & 36.54621 & Observed & 3 & 4 & 3.5 & 0.5 & 2.00 \\
\hline 1014 & $\begin{array}{c}- \\
72.99914 \\
\end{array}$ & $\begin{array}{c}- \\
36.72784 \\
\end{array}$ & $\begin{array}{c}- \\
72.99081 \\
\end{array}$ & $\begin{array}{c}- \\
36.73617 \\
\end{array}$ & Observed & 9.5 & 10.5 & 10 & 0.5 & 2.00 \\
\hline 1028 & 73.47727 & 38.23294 & 73.47727 & 38.22961 & Inferred & 4 & 10 & 7 & 3 & 0.33 \\
\hline 1029 & $\begin{array}{c}- \\
73.49290 \\
\end{array}$ & 38.24237 & 73.49290 & 38.25070 & Inferred & 4 & 10 & 7 & 3 & 0.33 \\
\hline 1052 & $\begin{array}{c}- \\
73.49333 \\
\end{array}$ & 38.24531 & $\begin{array}{c}- \\
73.49333 \\
\end{array}$ & $\begin{array}{c}- \\
38.25364 \\
\end{array}$ & Inferred & 4 & 10 & 7 & 3 & 0.33 \\
\hline 1053 & $\begin{array}{c}- \\
73.53908 \\
\end{array}$ & $\begin{array}{c}- \\
38.32806 \\
\end{array}$ & $\begin{array}{c}- \\
73.53700 \\
\end{array}$ & $\begin{array}{c}- \\
38.32806 \\
\end{array}$ & Inferred & 2 & 10 & 6 & 4 & 0.25 \\
\hline 1054 & $\begin{array}{c}- \\
73.54591 \\
\end{array}$ & $\begin{array}{c}- \\
38.34447\end{array}$ & $\begin{array}{c}- \\
73.48758\end{array}$ & $\begin{array}{c}- \\
38.34447\end{array}$ & Inferred & 2 & 10 & 6 & 4 & 0.25 \\
\hline
\end{tabular}


Table D6: The simulated tide gauges corresponding to tsunami observations used in the 1822 AIC analysis

\begin{tabular}{|c|c|c|c|c|c|c|c|c|c|c|}
\hline $\begin{array}{c}\text { Gauge } \\
\text { number }\end{array}$ & $\begin{array}{c}\text { Set run } \\
\text { longitude }\end{array}$ & $\begin{array}{c}\text { Set run } \\
\text { latitude }\end{array}$ & $\begin{array}{c}\text { Original } \\
\text { longitude }\end{array}$ & $\begin{array}{c}\text { Original } \\
\text { latitude }\end{array}$ & Type & $\begin{array}{c}\text { Inferred } \\
\text { min } \\
\text { observed } \\
\text { height }\end{array}$ & $\begin{array}{c}\text { Inferred } \\
\text { max } \\
\text { observed } \\
\text { height }\end{array}$ & $\begin{array}{c}\text { AVG } \\
\text { Height }\end{array}$ & $\begin{array}{c}\text { Standev } \\
\text { of } \\
\text { inferred } \\
\text { height }\end{array}$ & $\begin{array}{c}\text { Weighted } \\
\text { percentage } \\
\text { based on } \\
\text { standev }\end{array}$ \\
\hline 1002 & 71.61034 & 33.04254 & -71.99600 & 33.04271 & Observed & 3.1 & 4.1 & 3.6 & 0.5 & 2.00 \\
\hline 1066 & $\begin{array}{c}- \\
73.41765\end{array}$ & $\begin{array}{c}- \\
39.88387\end{array}$ & -73.42598 & $\begin{array}{c}- \\
39.88387\end{array}$ & Inferred & 0.5 & 2 & 1.25 & 0.75 & 1.33 \\
\hline 1106 & 71.49623 & 32.75048 & $\begin{array}{c}\hat{\mathrm{E}}- \\
71.465166\end{array}$ & 32.75595 & Inferred & 0.5 & 2 & 1.25 & 0.75 & 1.33 \\
\hline
\end{tabular}


Table D7: The simulated tide gauges corresponding to tsunami observations used in the 1835 AIC analysis

\begin{tabular}{|c|c|c|c|c|c|c|c|c|c|c|}
\hline $\begin{array}{c}\text { Gauge } \\
\text { number }\end{array}$ & $\begin{array}{c}\text { Set run } \\
\text { longitude }\end{array}$ & $\begin{array}{c}\text { Set run } \\
\text { latitude }\end{array}$ & $\begin{array}{c}\text { Original } \\
\text { longitude }\end{array}$ & $\begin{array}{c}\text { Original } \\
\text { latitude }\end{array}$ & Type & $\begin{array}{c}\text { Inferred } \\
\text { min } \\
\text { observed } \\
\text { height }\end{array}$ & $\begin{array}{c}\text { Inferred } \\
\text { max } \\
\text { observed } \\
\text { height }\end{array}$ & $\begin{array}{c}\text { AVG } \\
\text { Height }\end{array}$ & $\begin{array}{c}\text { Standev } \\
\text { of } \\
\text { inferred } \\
\text { height }\end{array}$ & $\begin{array}{c}\text { Weighted } \\
\text { percentage } \\
\text { based on } \\
\text { standev }\end{array}$ \\
\hline 1002 & -71.61034 & -33.04254 & -71.99600 & -33.04271 & Observed & 0.1 & 1.1 & 0.5 & 0.5 & 2.00 \\
\hline 1006 & -72.41963 & -35.31215 & -72.41130 & -35.31632 & Observed & 3 & 4 & 3.5 & 0.5 & 2.00 \\
\hline 1008 & -72.94457 & -36.53788 & -72.93624 & -36.54621 & Observed & 23.5 & 24.5 & 24 & 0.5 & 2.00 \\
\hline 1009 & -72.96708 & -36.63024 & -72.96333 & -36.61774 & Observed & 3.5 & 4.5 & 4 & 0.5 & 2.00 \\
\hline 1010 & -73.05687 & -36.63735 & -73.05999 & -36.63735 & Observed & 8.5 & 9.5 & 9 & 0.5 & 2.00 \\
\hline 1011 & -73.10445 & -36.72057 & -73.10445 & -36.72474 & Observed & 8.5 & 9.5 & 9 & 0.5 & 2.00 \\
\hline 1012 & -73.05561 & -36.73054 & -73.05561 & -36.73471 & Observed & 14.5 & 15.5 & 15 & 0.5 & 2.00 \\
\hline 1013 & -73.15707 & -36.72637 & -73.16166 & -36.73471 & Inferred & 3 & 9.5 & 6.25 & 3.25 & 0.31 \\
\hline 1014 & -72.99914 & -36.72784 & -72.99081 & -36.73617 & Inferred & 3 & 9.5 & 6.25 & 3.25 & 0.31 \\
\hline 1022 & -73.15494 & -37.03602 & -73.15494 & -37.03602 & Inferred & 3 & 9 & 6 & 3 & 0.33 \\
\hline 1023 & -73.42335 & -37.23425 & -73.42752 & -37.23425 & Inferred & 3 & 8 & 5.5 & 2.5 & 0.40 \\
\hline 1028 & -73.47727 & -38.23294 & -73.47727 & -38.22961 & Inferred & 4 & 8 & 6 & 2 & 0.50 \\
\hline 1029 & -73.49290 & -38.24237 & -73.49290 & -38.25070 & Inferred & 4 & 8 & 6 & 2 & 0.50 \\
\hline 1052 & -73.49333 & -38.24531 & -73.49333 & -38.25364 & Inferred & 4 & 8 & 6 & 2 & 0.50 \\
\hline 1055 & -73.87052 & -38.37881 & -73.86740 & -38.37465 & Inferred & 6 & 8 & 7 & 1 & 1.00 \\
\hline 1066 & -73.41765 & -39.88387 & -73.42598 & -39.88387 & Inferred & 3 & 6 & 4.5 & 1.5 & 0.67 \\
\hline 1101 & -74.04832 & -42.06002 & -74.04832 & -42.06002 & inferred & 0.25 & 2 & 1.125 & 0.875 & 1.14 \\
\hline
\end{tabular}


Table D8: The simulated tide gauges corresponding to tsunami observations used in the 1837 AIC analysis

\begin{tabular}{|c|c|c|c|c|c|c|c|c|c|c|}
\hline $\begin{array}{c}\text { Gauge } \\
\text { number }\end{array}$ & $\begin{array}{c}\text { Set run } \\
\text { longitude }\end{array}$ & $\begin{array}{c}\text { Set run } \\
\text { latitude }\end{array}$ & $\begin{array}{c}\text { Original } \\
\text { longitude }\end{array}$ & $\begin{array}{c}\text { Original } \\
\text { latitude }\end{array}$ & Type & $\begin{array}{c}\text { Inferred } \\
\text { min } \\
\text { observed } \\
\text { height }\end{array}$ & $\begin{array}{c}\text { Inferred } \\
\text { max } \\
\text { observed } \\
\text { height }\end{array}$ & $\begin{array}{c}\text { AVG } \\
\text { Height }\end{array}$ & $\begin{array}{c}\text { Standev } \\
\text { of } \\
\text { inferred } \\
\text { height }\end{array}$ & $\begin{array}{c}\text { Weighted } \\
\text { percentage } \\
\text { based on } \\
\text { standev }\end{array}$ \\
\hline 1002 & -71.61034 & -33.04254 & -71.99600 & -33.04271 & Observed & 0.5 & 1.5 & 1 & 0.5 & 2.00 \\
\hline 1012 & -73.05561 & -36.73054 & -73.05561 & -36.73471 & Inferred & 3 & 5 & 4 & 1 & 1.00 \\
\hline 1067 & -73.39912 & -39.89045 & -33.39495 & -39.89045 & Observed & 1.5 & 2.5 & 2 & 0.5 & 2.00 \\
\hline 1066 & -73.41765 & -39.88387 & -73.42598 & -39.88387 & Observed & $\begin{array}{c}1.00 \mathrm{E}- \\
15\end{array}$ & $\begin{array}{c}1.00 \mathrm{E}- \\
14\end{array}$ & $\begin{array}{c}1.00 \mathrm{E}- \\
13\end{array}$ & 0.5 & 2.00 \\
\hline 1072 & -73.72496 & -41.63177 & -73.67817 & -41.57341 & Inferred & 4.1 & 10 & 7.05 & 2.95 & 0.34 \\
\hline 1100 & -74.01731 & -41.88784 & -74.00065 & -41.84618 & Inferred & 3 & 5 & 4 & 1 & 1.00 \\
\hline 1101 & -74.04832 & -42.06002 & -74.04832 & -42.06002 & Inferred & $\begin{array}{c}1.00 \mathrm{E}- \\
15\end{array}$ & $\begin{array}{c}1.00 \mathrm{E}- \\
14\end{array}$ & $\begin{array}{c}1.00 \mathrm{E}- \\
13\end{array}$ & 0.5 & 2.00 \\
\hline 1103 & -74.19680 & -42.86273 & -74.19680 & -42.86273 & Inferred & 3 & 7 & 5 & 2 & 0.50 \\
\hline
\end{tabular}

\section{1}

Table D9: The simulated tide gauge corresponding to tsunami observations used in the 1871 AIC analysis

\begin{tabular}{|c|c|c|c|c|c|c|c|c|c|c|}
\hline $\begin{array}{c}\text { Gauge } \\
\text { number }\end{array}$ & $\begin{array}{c}\text { Set run } \\
\text { longitude }\end{array}$ & $\begin{array}{c}\text { Set run } \\
\text { latitude }\end{array}$ & $\begin{array}{c}\text { Original } \\
\text { longitude }\end{array}$ & $\begin{array}{c}\text { Original } \\
\text { latitude }\end{array}$ & Type & $\begin{array}{c}\text { Inferred } \\
\text { min } \\
\text { observed } \\
\text { height }\end{array}$ & $\begin{array}{c}\text { Inferred } \\
\text { max } \\
\text { observed } \\
\text { height }\end{array}$ & $\begin{array}{c}\text { AVG } \\
\text { Height }\end{array}$ & $\begin{array}{c}\text { Standev } \\
\text { of } \\
\text { inferred } \\
\text { height }\end{array}$ & $\begin{array}{c}\text { Weighted } \\
\text { percentage } \\
\text { based on } \\
\text { standev }\end{array}$ \\
\hline 1002 & 71.61034 & 33.04254 & 71.61034 & 33.04254 & Observed & 0.5 & 1.5 & 1 & 0.5 & 2.00 \\
\hline
\end{tabular}


Table D10: The simulated tide gauge corresponding to tsunami observations used in the 1871b AIC analysis

\begin{tabular}{|c|c|c|c|c|c|c|c|c|c|c|}
\hline $\begin{array}{c}\text { Gauge } \\
\text { number }\end{array}$ & $\begin{array}{c}\text { Set run } \\
\text { longitude }\end{array}$ & $\begin{array}{c}\text { Set run } \\
\text { latitude }\end{array}$ & $\begin{array}{c}\text { Original } \\
\text { longitude }\end{array}$ & $\begin{array}{c}\text { Original } \\
\text { latitude }\end{array}$ & Type & $\begin{array}{c}\text { Inferred } \\
\text { min } \\
\text { observed } \\
\text { height }\end{array}$ & $\begin{array}{c}\text { Inferred } \\
\text { max } \\
\text { observed } \\
\text { height }\end{array}$ & $\begin{array}{c}\text { AVG } \\
\text { Height }\end{array}$ & $\begin{array}{c}\text { Standev } \\
\text { of } \\
\text { inferred } \\
\text { height }\end{array}$ & $\begin{array}{c}\text { Weighted } \\
\text { percentage } \\
\text { based on } \\
\text { standev }\end{array}$ \\
\hline 1070 & 72.95222 & 41.48602 & 72.96388 & 41.48602 & Observed & 0.5 & 1.5 & 1 & 0.5 & 2.00 \\
\hline
\end{tabular}

1898

Table D11: The simulated tide gauge corresponding to tsunami observations used in the 1898 AIC analysis

\begin{tabular}{|c|c|c|c|c|c|c|c|c|c|c|}
\hline $\begin{array}{c}\text { Gauge } \\
\text { number }\end{array}$ & $\begin{array}{c}\text { Set run } \\
\text { longitude }\end{array}$ & $\begin{array}{c}\text { Set run } \\
\text { latitude }\end{array}$ & $\begin{array}{c}\text { Original } \\
\text { longitude }\end{array}$ & $\begin{array}{c}\text { Original } \\
\text { latitude }\end{array}$ & Type & $\begin{array}{c}\text { Inferred } \\
\text { min } \\
\text { observed } \\
\text { height }\end{array}$ & $\begin{array}{c}\text { Inferred } \\
\text { max } \\
\text { observed } \\
\text { height }\end{array}$ & $\begin{array}{c}\text { AVG } \\
\text { Height }\end{array}$ & $\begin{array}{c}\text { Standev } \\
\text { of } \\
\text { inferred } \\
\text { height }\end{array}$ & $\begin{array}{c}\text { Weighted } \\
\text { percentage } \\
\text { based on } \\
\text { standev }\end{array}$ \\
\hline 1012 & 73.05561 & 36.73054 & 73.05561 & 36.73471 & Observed & 0.2 & 1.2 & 0.7 & 0.5 & 2.00 \\
\hline
\end{tabular}


Table D12: The simulated tide gauges corresponding to tsunami observations used in the 1906 AIC analysis

\begin{tabular}{|c|c|c|c|c|c|c|c|c|c|c|}
\hline $\begin{array}{c}\text { Gauge } \\
\text { number }\end{array}$ & $\begin{array}{c}\text { Set run } \\
\text { longitude }\end{array}$ & $\begin{array}{c}\text { Set run } \\
\text { latitude }\end{array}$ & $\begin{array}{c}\text { Original } \\
\text { longitude }\end{array}$ & $\begin{array}{c}\text { Original } \\
\text { latitude }\end{array}$ & Type & $\begin{array}{c}\text { Inferred } \\
\text { min } \\
\text { observed } \\
\text { height }\end{array}$ & $\begin{array}{c}\text { Inferred } \\
\text { max } \\
\text { observed } \\
\text { height }\end{array}$ & $\begin{array}{c}\text { AVG } \\
\text { Height }\end{array}$ & $\begin{array}{c}\text { Standev } \\
\text { of } \\
\text { inferred } \\
\text { height }\end{array}$ & $\begin{array}{c}\text { Weighted } \\
\text { percentage } \\
\text { based on } \\
\text { standev }\end{array}$ \\
\hline 1002 & 71.61034 & 33.04254 & 71.99600 & 33.04271 & Observed & 3.1 & 4.1 & 3.6 & 0.5 & 2.00 \\
\hline 1004 & 72.21120 & 35.10968 & 72.21120 & 35.10968 & Inferred & 0.5 & 2 & 1.25 & 0.75 & 1.33 \\
\hline 1005 & 72.42500 & 35.31588 & 72.42500 & 35.31588 & Inferred & 0.5 & 2 & 1.25 & 0.75 & 1.33 \\
\hline 1006 & 72.41963 & 35.31215 & 72.41130 & 35.31632 & Observed & 0.5 & 1.5 & 1 & 0.5 & 2.00 \\
\hline 1009 & 72.96708 & 36.63024 & 72.96333 & 36.61774 & Observed & 1 & 2 & 1.5 & 0.5 & 2.00 \\
\hline 1011 & 73.10445 & 36.72057 & 73.10445 & 36.72474 & Observed & 0.9 & 1.9 & 1.4 & 0.5 & 2.00 \\
\hline 1014 & 72.99914 & 36.72784 & 72.99081 & 36.73617 & Observed & 1 & 2 & 1.5 & 0.5 & 2.00 \\
\hline 1022 & 73.15494 & 37.03602 & 73.14661 & 37.03602 & Inferred & 0.5 & 2.5 & 1.5 & 1 & 1.00 \\
\hline 1107 & 71.51217 & 31.91211 & 71.51158 & 31.90929 & Inferred & 1 & 3 & 2 & 1 & 1.00 \\
\hline
\end{tabular}


Table D13: The simulated tide gauges corresponding to tsunami observations used in the 1920 AIC analysis

\begin{tabular}{|c|c|c|c|c|c|c|c|c|c|c|}
\hline $\begin{array}{l}\text { Gauge } \\
\text { number }\end{array}$ & $\begin{array}{l}\text { Set run } \\
\text { longitude }\end{array}$ & $\begin{array}{l}\text { Set run } \\
\text { latitude }\end{array}$ & $\begin{array}{c}\text { Original } \\
\text { longitude }\end{array}$ & $\begin{array}{l}\text { Original } \\
\text { latitude }\end{array}$ & Type & $\begin{array}{l}\text { Inferred } \\
\text { min } \\
\text { observed } \\
\text { height }\end{array}$ & $\begin{array}{c}\text { Inferred } \\
\text { max } \\
\text { observed } \\
\text { height }\end{array}$ & $\begin{array}{c}\text { AVG } \\
\text { Height }\end{array}$ & $\begin{array}{l}\text { Standev } \\
\text { of } \\
\text { inferred } \\
\text { height }\end{array}$ & $\begin{array}{c}\text { Weighted } \\
\text { percentage } \\
\text { based on } \\
\text { standev }\end{array}$ \\
\hline 1011 & $73 . \overline{10445}$ & 36.72057 & 73.10445 & 36.72474 & Observed & 0.9 & 1.9 & 1.4 & 0.5 & 2.00 \\
\hline 1025 & $\begin{array}{c}- \\
73.48369 \\
\end{array}$ & $\begin{array}{c}- \\
37.99779 \\
\end{array}$ & 73.47869 & 37.99779 & Observed & 0.9 & 1.9 & 1.4 & 0.5 & 2.00 \\
\hline 1026 & $\begin{array}{c}- \\
73.48082 \\
\end{array}$ & 38.01159 & $\begin{array}{c}- \\
73.48082 \\
\end{array}$ & 38.01159 & Observed & 0.9 & 1.9 & 1.4 & 0.5 & 2.00 \\
\hline 1027 & $\begin{array}{c}- \\
73.46170\end{array}$ & $\begin{array}{c}- \\
38.08409\end{array}$ & $\begin{array}{c}- \\
73.46170\end{array}$ & $\begin{array}{c}- \\
38.08409\end{array}$ & Observed & 0.9 & 1.9 & 1.4 & 0.5 & 2.00 \\
\hline
\end{tabular}

Table D14: The simulated tide gauges corresponding to tsunami observations used in the 1927 AIC analysis

\begin{tabular}{|c|c|c|c|c|c|c|c|c|c|c|}
\hline $\begin{array}{c}\text { Gauge } \\
\text { number }\end{array}$ & $\begin{array}{c}\text { Set run } \\
\text { longitude }\end{array}$ & $\begin{array}{c}\text { Set run } \\
\text { latitude }\end{array}$ & $\begin{array}{c}\text { Original } \\
\text { longitude }\end{array}$ & $\begin{array}{c}\text { Original } \\
\text { latitude }\end{array}$ & Type & $\begin{array}{c}\text { Inferred } \\
\text { min } \\
\text { observed } \\
\text { height }\end{array}$ & $\begin{array}{c}\text { Inferred } \\
\text { max } \\
\text { observed } \\
\text { height }\end{array}$ & $\begin{array}{c}\text { AVG } \\
\text { Height }\end{array}$ & $\begin{array}{c}\text { Standev } \\
\text { of } \\
\text { inferred } \\
\text { height }\end{array}$ & $\begin{array}{c}\text { Weighted } \\
\text { percentage } \\
\text { based on } \\
\text { standev }\end{array}$ \\
\hline 1104 & -52.70921 & 44.72976 & 72.68421 & 44.73059 & Observed & 2.3 & 3.3 & 2.8 & 0.5 & 2.00 \\
\hline 1105 & 72.84226 & 45.40258 & 72.82976 & 45.40258 & Inferred & 3 & 5 & 4 & 1 & 1.00 \\
\hline
\end{tabular}


Table D15: The simulated tide gauges corresponding to tsunami observations used in the 1928 AIC analysis

\begin{tabular}{|c|c|c|c|c|c|c|c|c|c|c|}
\hline $\begin{array}{c}\text { Gauge } \\
\text { number }\end{array}$ & $\begin{array}{c}\text { Set run } \\
\text { longitude }\end{array}$ & $\begin{array}{c}\text { Set run } \\
\text { latitude }\end{array}$ & $\begin{array}{c}\text { Original } \\
\text { longitude }\end{array}$ & $\begin{array}{c}\text { Original } \\
\text { latitude }\end{array}$ & Type & $\begin{array}{c}\text { Inferred } \\
\text { min } \\
\text { observed } \\
\text { height }\end{array}$ & $\begin{array}{c}\text { Inferred } \\
\text { max } \\
\text { observed } \\
\text { height }\end{array}$ & $\begin{array}{c}\text { AVG } \\
\text { Height }\end{array}$ & $\begin{array}{c}\text { Standev } \\
\text { of } \\
\text { inferred } \\
\text { height }\end{array}$ & $\begin{array}{c}\text { Weighted } \\
\text { percentage } \\
\text { based on } \\
\text { standev }\end{array}$ \\
\hline 1004 & 72.21120 & 35.10968 & 72.21120 & 35.10968 & inferred & 0.5 & 2.5 & 1.5 & 1 & 1.00 \\
\hline 1006 & - & - & - & - & observed & 1 & 2 & 1.5 & 0.5 & 2.00 \\
\hline
\end{tabular}

Table D16: The simulated tide gauge corresponding to tsunami observations used in the 1943 AIC analysis

\begin{tabular}{|c|c|c|c|c|c|c|c|c|c|c|}
\hline $\begin{array}{c}\text { Gauge } \\
\text { number }\end{array}$ & $\begin{array}{c}\text { Set run } \\
\text { longitude }\end{array}$ & $\begin{array}{c}\text { Set run } \\
\text { latitude }\end{array}$ & $\begin{array}{c}\text { Original } \\
\text { longitude }\end{array}$ & $\begin{array}{c}\text { Original } \\
\text { latitude }\end{array}$ & Type & $\begin{array}{c}\text { Inferred } \\
\text { min } \\
\text { observed } \\
\text { height }\end{array}$ & $\begin{array}{c}\text { Inferred } \\
\text { max } \\
\text { observed } \\
\text { height }\end{array}$ & $\begin{array}{c}\text { AVG } \\
\text { Height }\end{array}$ & $\begin{array}{c}\text { Standev } \\
\text { of } \\
\text { inferred } \\
\text { height }\end{array}$ & $\begin{array}{c}\text { Weighted } \\
\text { percentage } \\
\text { based on } \\
\text { standev }\end{array}$ \\
\hline 1107 & 71.51217 & 31.91211 & 71.51158 & 31.90929 & Observed & 0.5 & 1.5 & 1 & 0.5 & 2.00 \\
\hline
\end{tabular}




\section{0}

Table D17: The simulated tide gauges corresponding to tsunami observations used in the 1960 AIC analysis

\begin{tabular}{|c|c|c|c|c|c|c|c|c|c|c|}
\hline $\begin{array}{l}\text { Gauge } \\
\text { number }\end{array}$ & $\begin{array}{l}\text { Set run } \\
\text { longitude }\end{array}$ & $\begin{array}{l}\text { Set run } \\
\text { latitude }\end{array}$ & $\begin{array}{c}\text { Original } \\
\text { longitude }\end{array}$ & $\begin{array}{l}\text { Original } \\
\text { latitude }\end{array}$ & Type & $\begin{array}{l}\text { Inferred } \\
\text { min } \\
\text { observed } \\
\text { height }\end{array}$ & $\begin{array}{c}\text { Inferred } \\
\text { max } \\
\text { observed } \\
\text { height }\end{array}$ & $\begin{array}{l}\text { AVG } \\
\text { Height }\end{array}$ & $\begin{array}{l}\text { Standev } \\
\text { of } \\
\text { inferred } \\
\text { height }\end{array}$ & $\begin{array}{l}\text { Weighted } \\
\text { percentage } \\
\text { based on } \\
\text { standev }\end{array}$ \\
\hline 1006 & -72.41963 & -35.31215 & -72.41130 & -35.31632 & Observed & 2 & 3 & 2.5 & 0.5 & 2.00 \\
\hline 1011 & -73.10445 & -36.72057 & -73.10445 & -36.72474 & Observed & 4.6 & 5.6 & 5.1 & 0.5 & 2.00 \\
\hline 1013 & -73.15707 & -36.72637 & -73.16166 & -36.73471 & Inferred & 3 & 5 & 4 & 1 & 1.00 \\
\hline 1014 & -72.99914 & -36.72784 & -72.99081 & -36.73617 & Inferred & 3 & 5 & 4 & 1 & 1.00 \\
\hline 1015 & -73.16522 & -36.77093 & -73.17249 & -36.76566 & Inferred & 3 & 5 & 4 & 1 & 1.00 \\
\hline 1022 & -73.15494 & -37.03602 & -73.14661 & -37.03602 & Observed & 1.5 & 2.5 & 2 & 0.5 & 2.00 \\
\hline 1023 & -73.42335 & -37.23425 & -73.42752 & -37.23425 & Inferred & 3 & 5 & 4 & 1 & 1.00 \\
\hline 1024 & -73.54026 & -37.89854 & -73.54026 & -37.89854 & Inferred & 4 & 6 & 5 & 1 & 1.00 \\
\hline 1028 & -73.47727 & -38.23294 & -73.47727 & -38.22961 & Inferred & 4 & 11 & 7.5 & 3.5 & 0.29 \\
\hline 1029 & -73.49290 & -38.24237 & -73.49290 & -38.25070 & Inferred & 4 & 11 & 7.5 & 3.5 & 0.29 \\
\hline 1052 & -73.49333 & -38.24531 & -73.49333 & -38.25364 & Inferred & 4 & 11 & 7.5 & 3.5 & 0.29 \\
\hline 1053 & -73.53908 & -38.32806 & -73.53700 & -38.32806 & Inferred & 2 & 9 & 5.5 & 3.5 & 0.29 \\
\hline 1054 & -73.54591 & -38.34447 & -73.48758 & -38.34447 & Inferred & 2 & 9 & 5.5 & 3.5 & 0.29 \\
\hline 1055 & -73.87052 & -38.37881 & -73.86740 & -38.37465 & Observed & 24.5 & 25.5 & 25 & 0.5 & 2.00 \\
\hline 1056 & -73.46712 & -38.71792 & -73.47045 & -38.71792 & Observed & 11 & 12 & 11.5 & 0.5 & 2.00 \\
\hline 1058 & -73.42258 & -38.78532 & -73.42675 & -38.78532 & Observed & 11 & 12 & 11.5 & 0.5 & 2.00 \\
\hline 1059 & -73.28660 & -39.12751 & -73.28660 & -39.12751 & Inferred & 4 & 8 & 6 & 2 & 0.50 \\
\hline 1060 & -73.23603 & -39.28183 & -73.24019 & -39.28183 & Observed & 14.5 & 15.5 & 15 & 0.5 & 2.00 \\
\hline 1061 & -73.22780 & -39.35852 & -73.23197 & -39.35852 & Inferred & 6 & 8 & 7 & 1 & 1.00 \\
\hline 1062 & -73.24635 & -39.42700 & -73.24635 & -39.42700 & Inferred & 8 & 15 & 11.5 & 3.5 & 0.29 \\
\hline 1066 & -73.41765 & -39.88387 & -73.42598 & -39.88387 & Observed & 9.5 & 10.5 & 10 & 0.5 & 2.00 \\
\hline
\end{tabular}




\begin{tabular}{|c|c|c|c|c|c|c|c|c|c|c|}
\hline $\begin{array}{c}\text { Gauge } \\
\text { number }\end{array}$ & $\begin{array}{c}\text { Set run } \\
\text { longitude }\end{array}$ & $\begin{array}{c}\text { Set run } \\
\text { latitude }\end{array}$ & $\begin{array}{c}\text { Original } \\
\text { longitude }\end{array}$ & $\begin{array}{c}\text { Original } \\
\text { latitude }\end{array}$ & Type & $\begin{array}{c}\text { Inferred } \\
\text { min } \\
\text { observed } \\
\text { height }\end{array}$ & $\begin{array}{c}\text { Inferred } \\
\text { max } \\
\text { observed } \\
\text { height }\end{array}$ & $\begin{array}{c}\text { AVG } \\
\text { Height }\end{array}$ & $\begin{array}{c}\text { Standev } \\
\text { of } \\
\text { inferred } \\
\text { height }\end{array}$ & $\begin{array}{c}\text { Weighted } \\
\text { percentage } \\
\text { based on } \\
\text { standev }\end{array}$ \\
\hline 1067 & -73.39912 & -39.89045 & -33.39495 & -39.89045 & Observed & 9.5 & 10.5 & 10 & 0.5 & 2.00 \\
\hline 1068 & -73.59558 & -39.94386 & -73.59558 & -39.94386 & Inferred & 6 & 8 & 7 & 1 & 1.00 \\
\hline 1069 & -73.74307 & -40.53544 & -73.74327 & -40.53536 & Inferred & 7 & 8 & 7.5 & 0.5 & 2.00 \\
\hline 1072 & -73.72496 & -41.63177 & -73.67817 & -41.57341 & Observed & 9 & 10 & 9.5 & 0.5 & 2.00 \\
\hline 1100 & -74.01731 & -41.88784 & -74.00065 & -41.84618 & Observed & 4.5 & 5.5 & 5 & 0.5 & 2.00 \\
\hline 1101 & -74.04832 & -42.06002 & -74.04832 & -42.06002 & Inferred & 7 & 12 & 9.5 & 2.5 & 0.40 \\
\hline 1103 & -74.19680 & -42.86273 & -74.19680 & -42.86273 & Inferred & 5 & 12 & 8.5 & 3.5 & 0.29 \\
\hline 1104 & -72.70921 & -44.72976 & -72.68421 & -44.73059 & Observed & 2.3 & 3.3 & 2.8 & 0.5 & 2.00 \\
\hline 1105 & -72.84226 & -45.40258 & -72.82976 & -45.40258 & Observed & 2.5 & 3.5 & 3 & 0.5 & 2.00 \\
\hline
\end{tabular}




\section{APPENDIXE}

The following 17 figures each illustrate a specific overview of all source models in the AIC statistical analysis for a given earthquake event. Earthquake source models with lower $\Delta_{\mathrm{i}}$ values were selected by the AIC equations as better matches to a specific event within the historical record based on the observations available. 


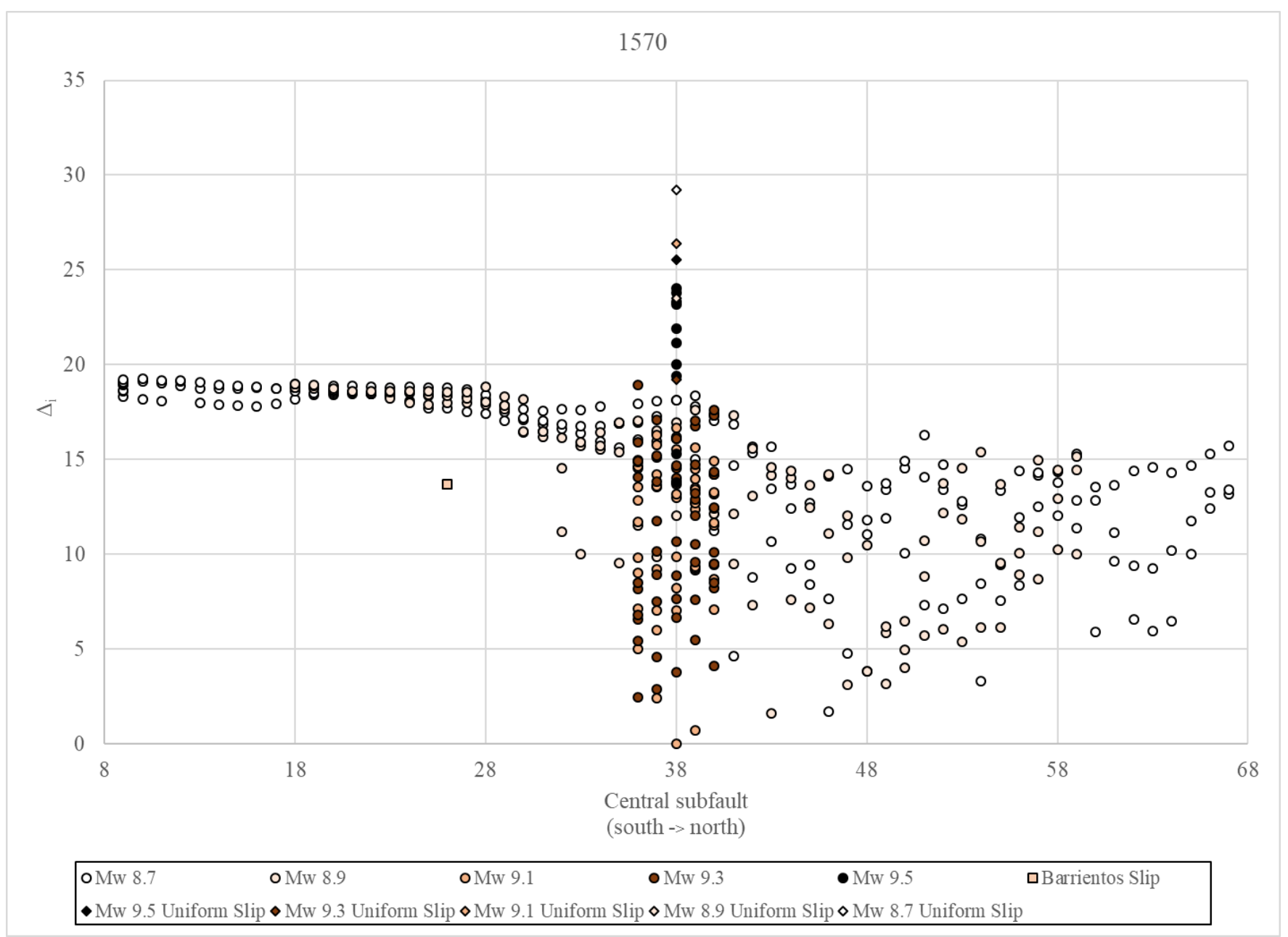

Appendix $\mathrm{E}_{1}$ : The $\Delta_{\mathrm{i}}$ versus central subfault of rupture for all tsunami simulations relative to the lowest AIC value calculated from observations of the 1570 historical tsunami. Earthquake magnitude positively correlates to darker colored data points. 


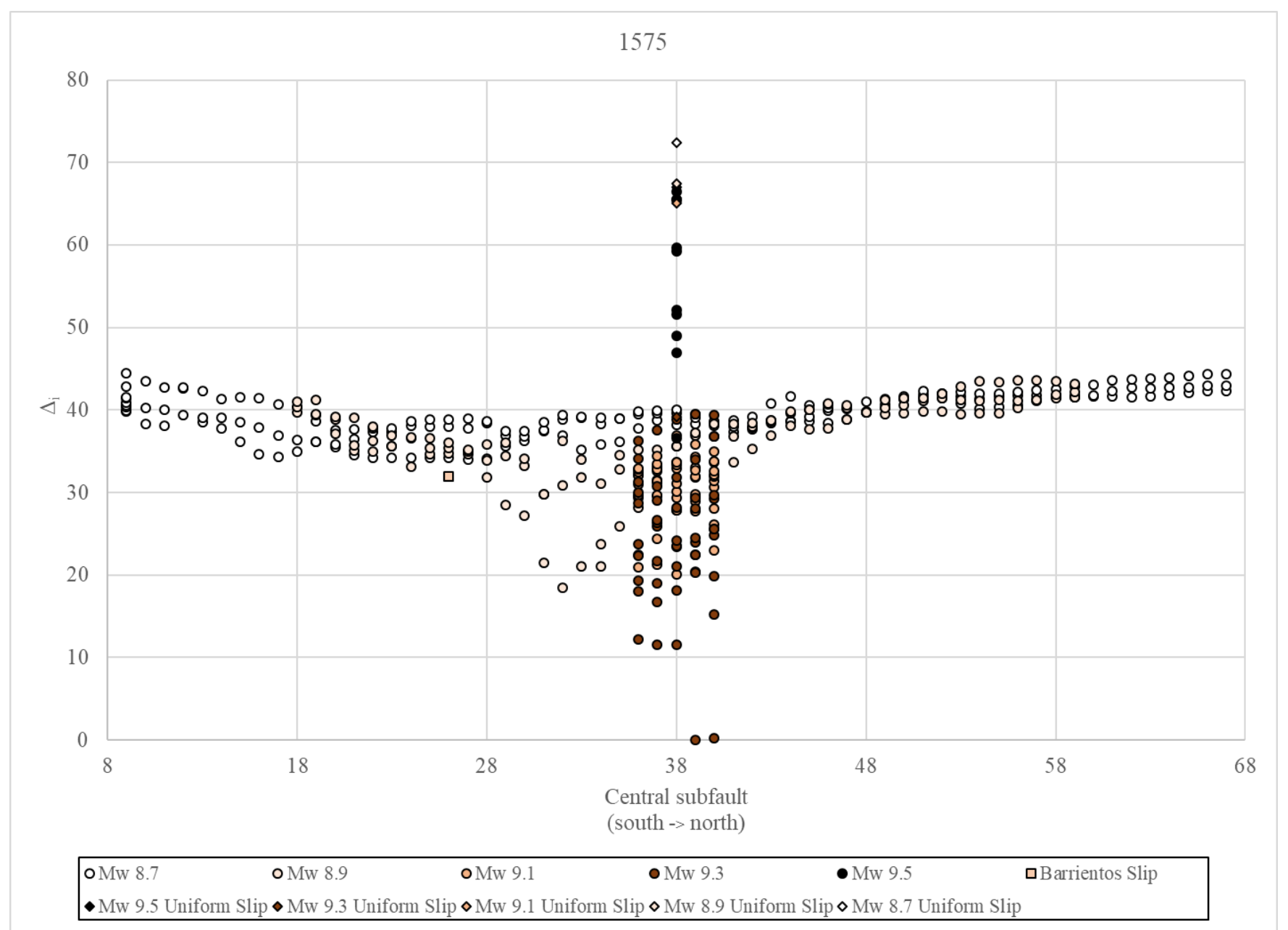

Appendix $\mathrm{E}_{2}$ : The $\Delta_{\mathrm{i}}$ versus central subfault of rupture for all tsunami simulations relative to the lowest AIC value calculated from observations of the 1575 historical tsunami. Earthquake magnitude positively correlates to darker colored data points. 


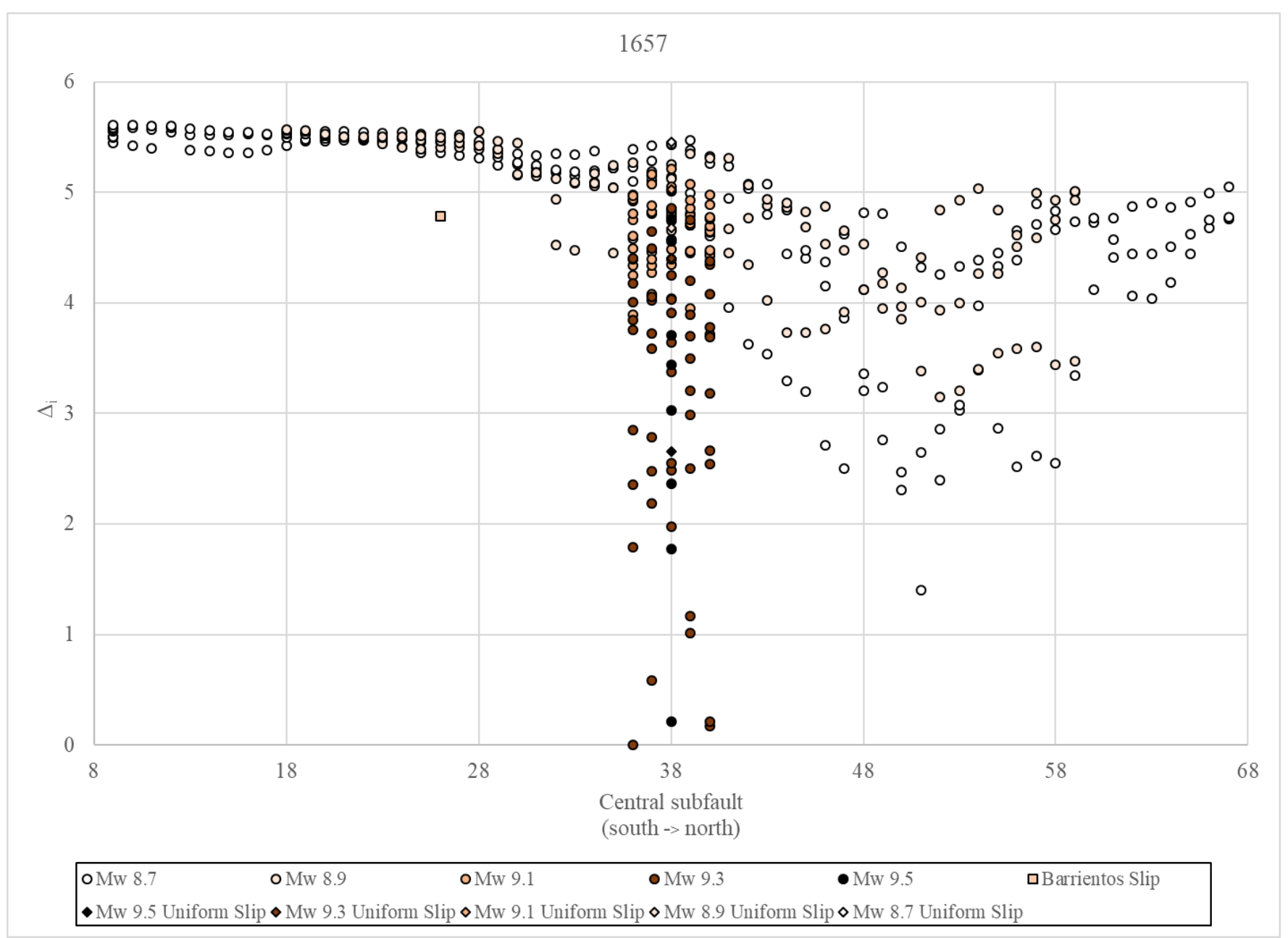

Appendix $\mathrm{E}_{3}$ : The $\Delta_{\mathrm{i}}$ versus central subfault of rupture for all tsunami simulations relative to the lowest AIC value calculated from observations of the 1657 historical tsunami. Earthquake magnitude positively correlates to darker colored data points. 


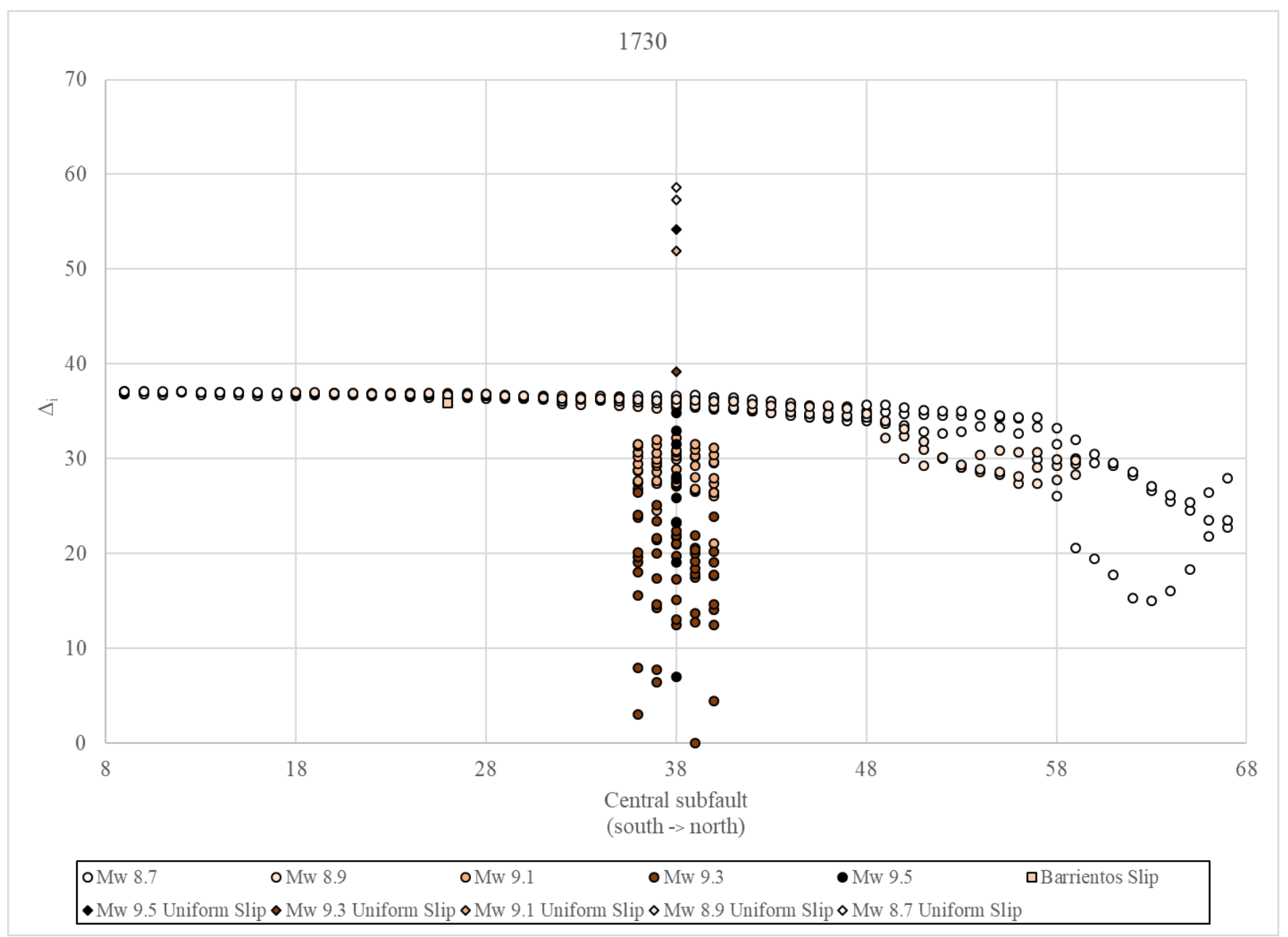

Appendix $\mathrm{E}_{4}$ : The $\Delta_{\mathrm{i}}$ versus central subfault of rupture for all tsunami simulations relative to the lowest AIC value calculated from observations of the 1730 historical tsunami. Earthquake magnitude positively correlates to darker colored data points. 


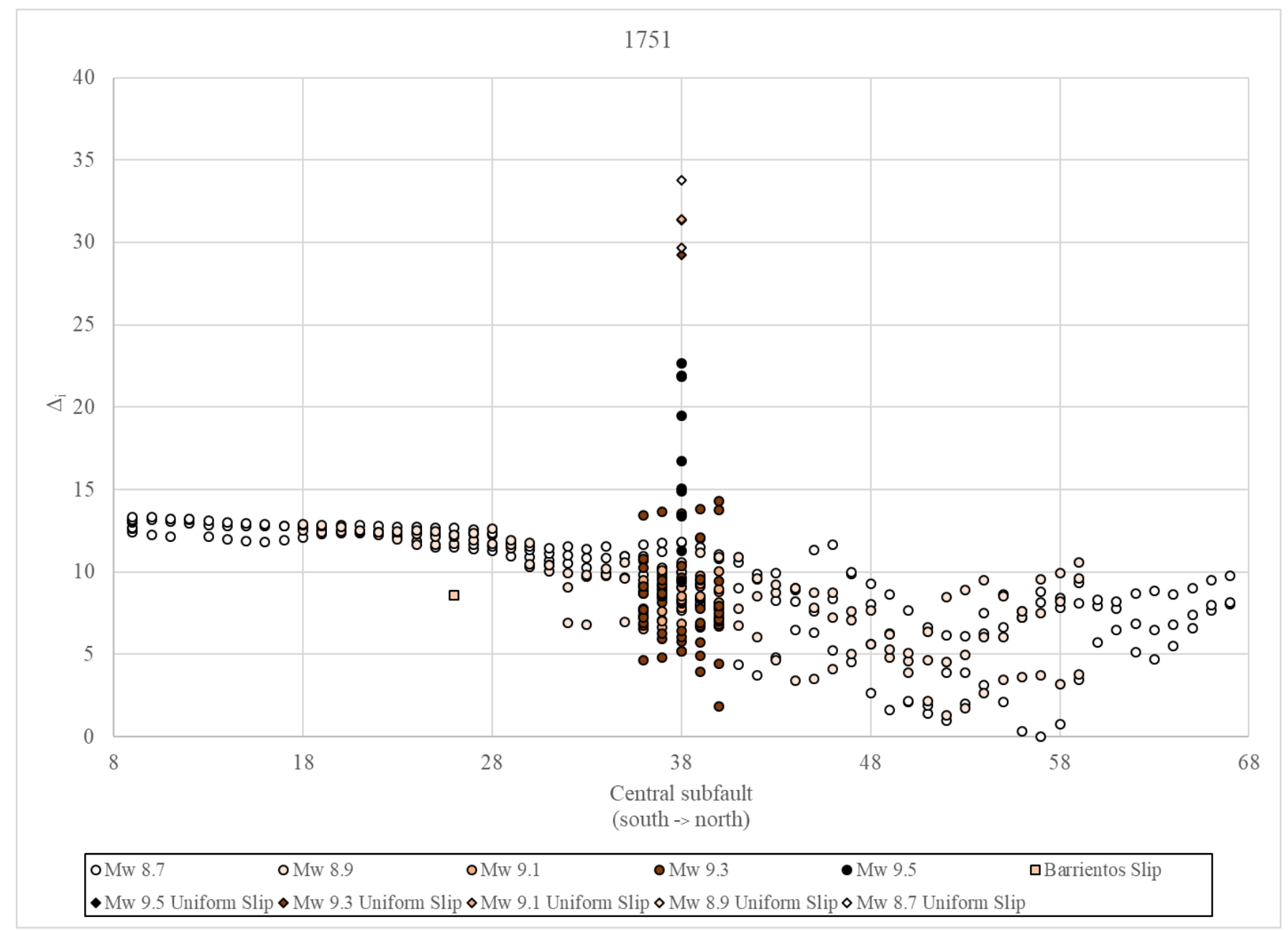

Appendix $\mathrm{E}_{5}$ : The $\Delta_{\mathrm{i}}$ versus central subfault of rupture for all tsunami simulations relative to the lowest AIC value calculated from observations of the 1751 historical tsunami. Earthquake magnitude positively correlates to darker colored data points. 


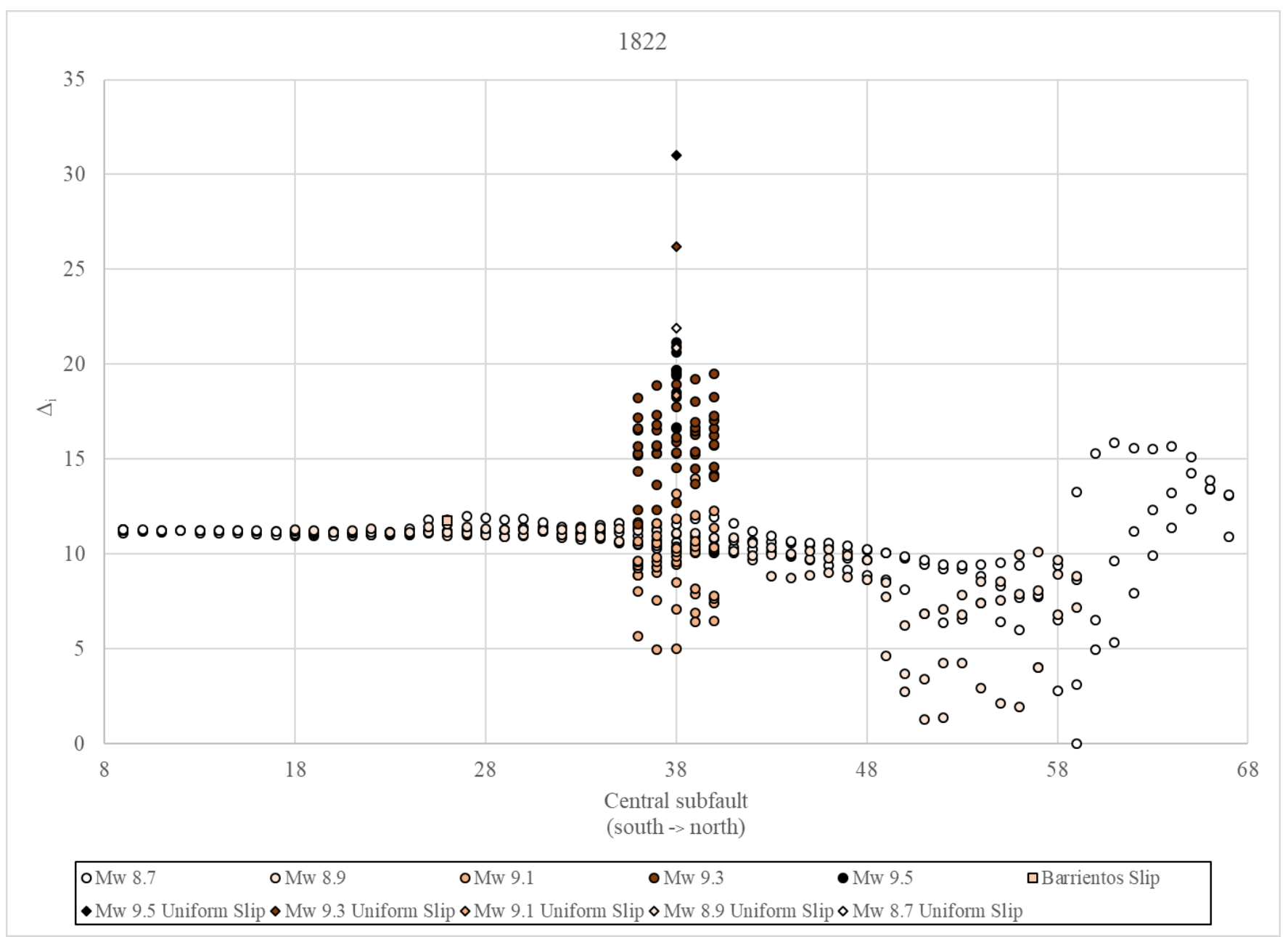

Appendix $\mathrm{E}_{6}$ : The $\Delta_{\mathrm{i}}$ versus central subfault of rupture for all tsunami simulations relative to the lowest AIC value calculated from observations of the 1822 historical tsunami. Earthquake magnitude positively correlates to darker colored data points. 


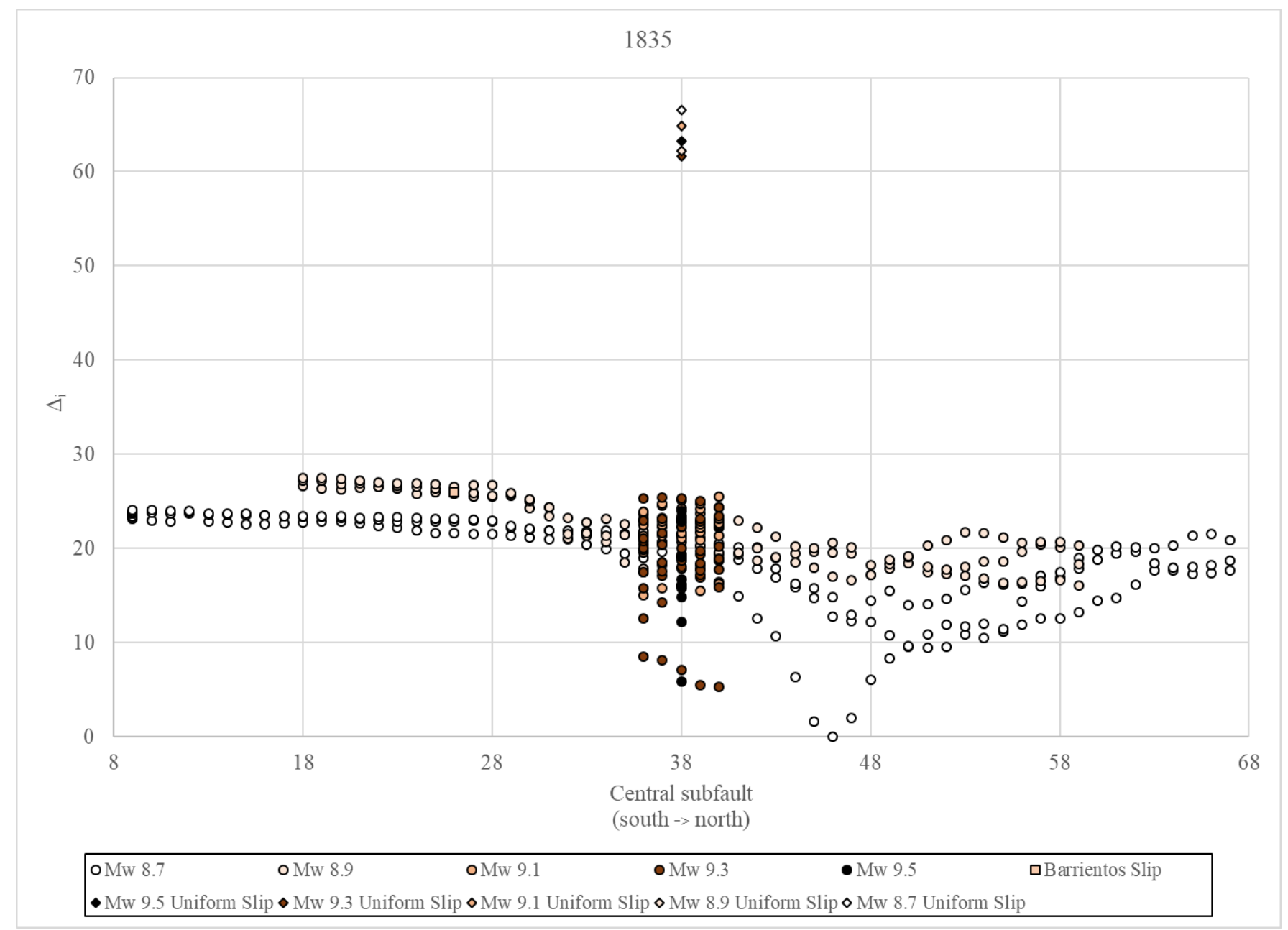

Appendix $\mathrm{E}_{7}$ : The $\Delta_{\mathrm{i}}$ versus central subfault of rupture for all tsunami simulations relative to the lowest AIC value calculated from observations of the 1835 historical tsunami. Earthquake magnitude positively correlates to darker colored data points.

212 


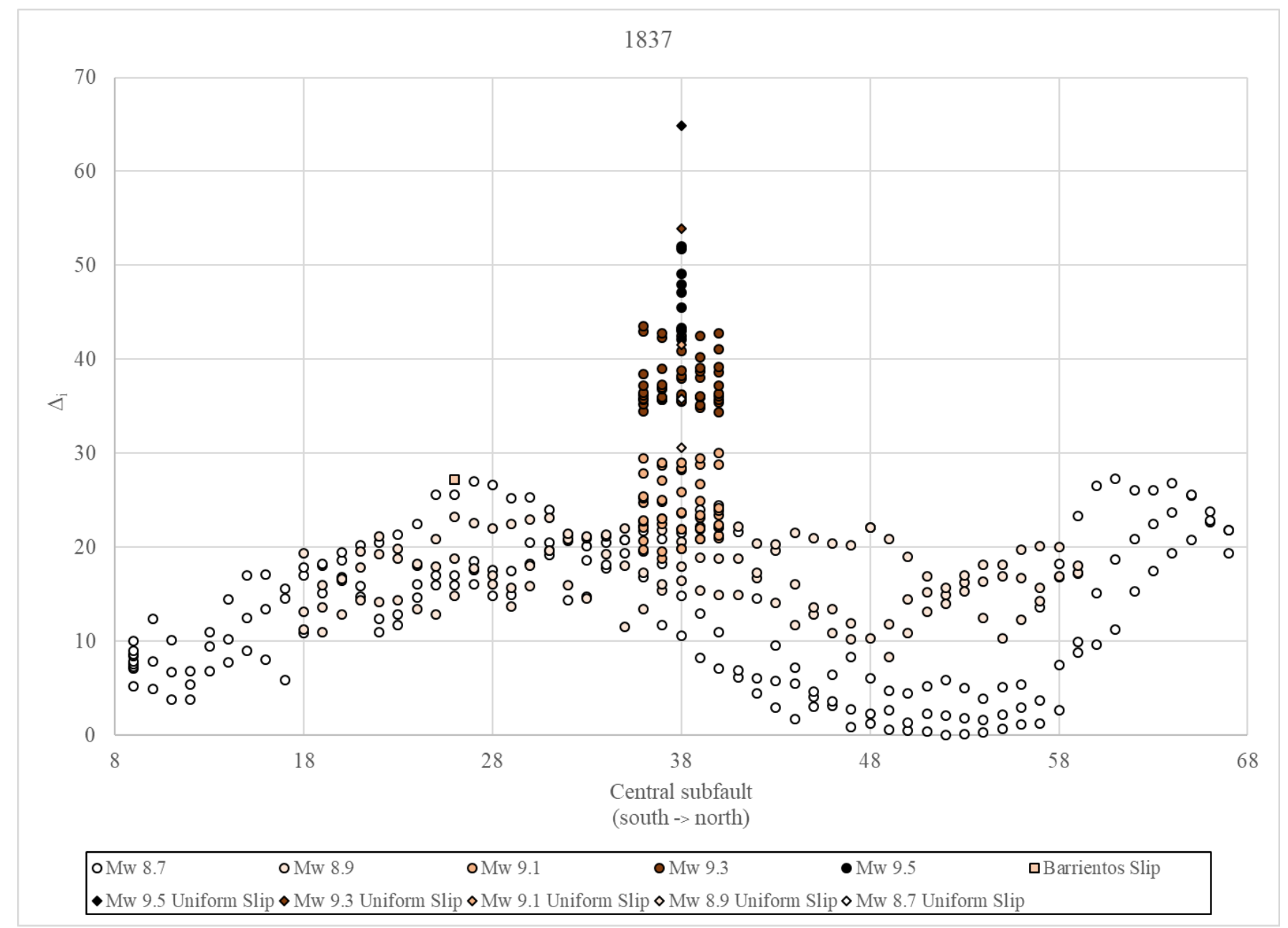

Appendix $\mathrm{E}_{8}$ : The $\Delta_{\mathrm{i}}$ versus central subfault of rupture for all tsunami simulations relative to the lowest AIC value calculated from observations of the 1835 historical tsunami. Earthquake magnitude positively correlates to darker colored data points. 


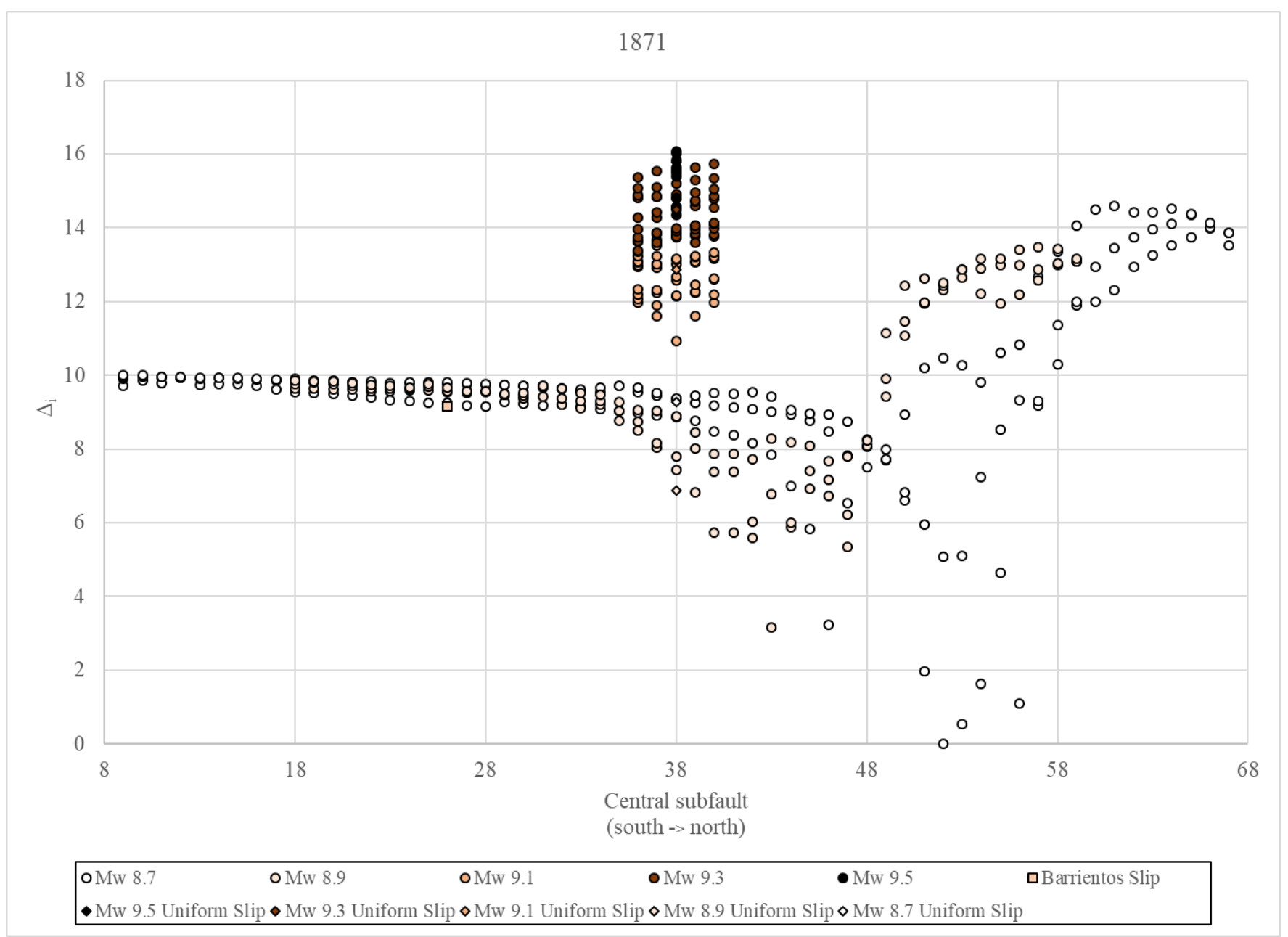

Appendix $\mathrm{E}_{9}$ : The $\Delta_{\mathrm{i}}$ versus central subfault of rupture for all tsunami simulations relative to the lowest AIC value calculated from observations of the 1871 historical tsunami. Earthquake magnitude positively correlates to darker colored data points. 


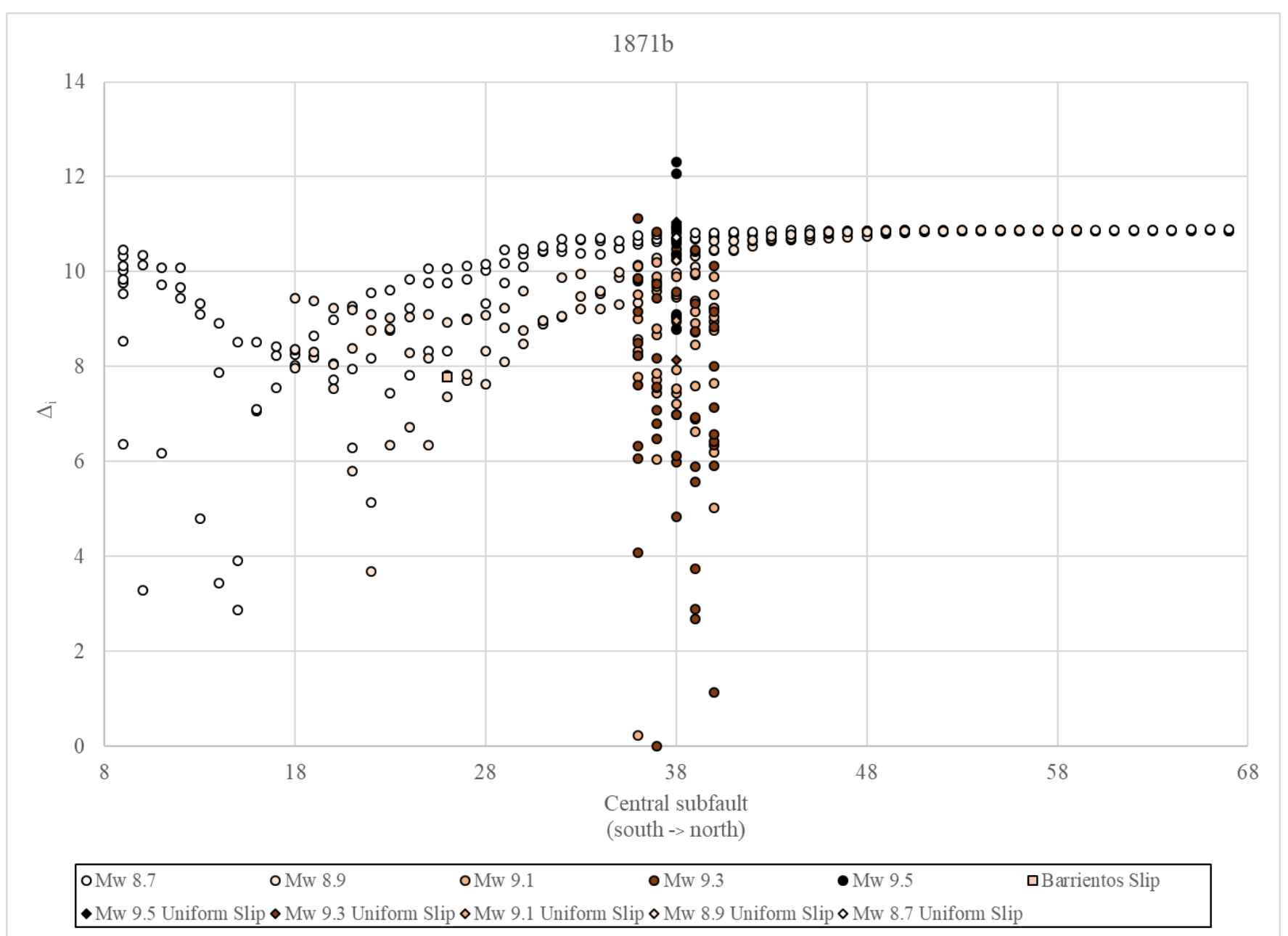

Appendix $\mathrm{E}_{10}$ : The $\Delta_{\mathrm{i}}$ versus central subfault of rupture for all tsunami simulations relative to the lowest AIC value calculated from observations of the $1871 \mathrm{~b}$ historical tsunami. Earthquake magnitude positively correlates to darker colored data points. 


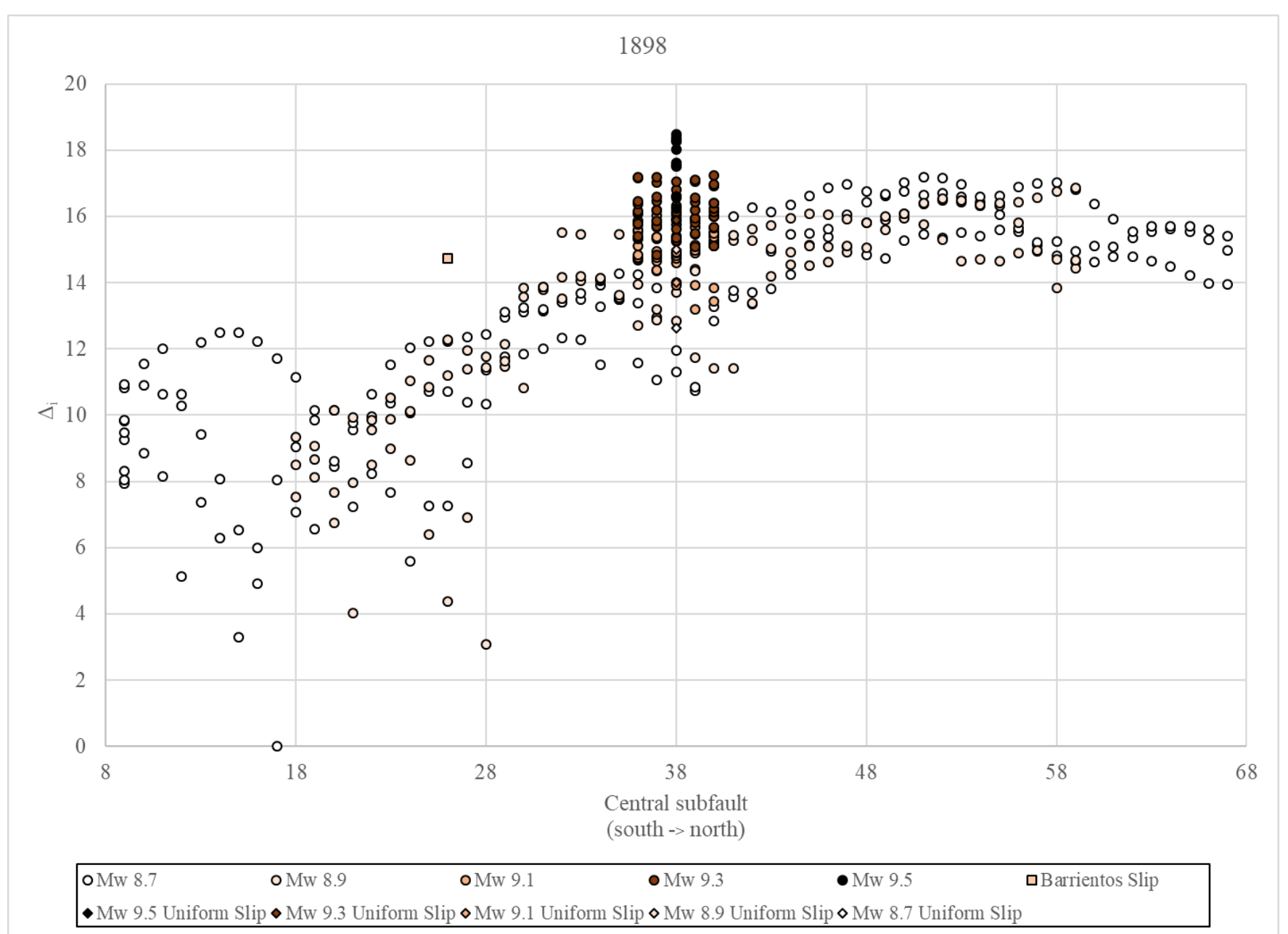

Appendix $\mathrm{E}_{11}$ : The $\Delta_{\mathrm{i}}$ versus central subfault of rupture for all tsunami simulations relative to the lowest AIC value calculated from observations of the 1898 historical tsunami. Earthquake magnitude positively correlates to darker colored data points. 


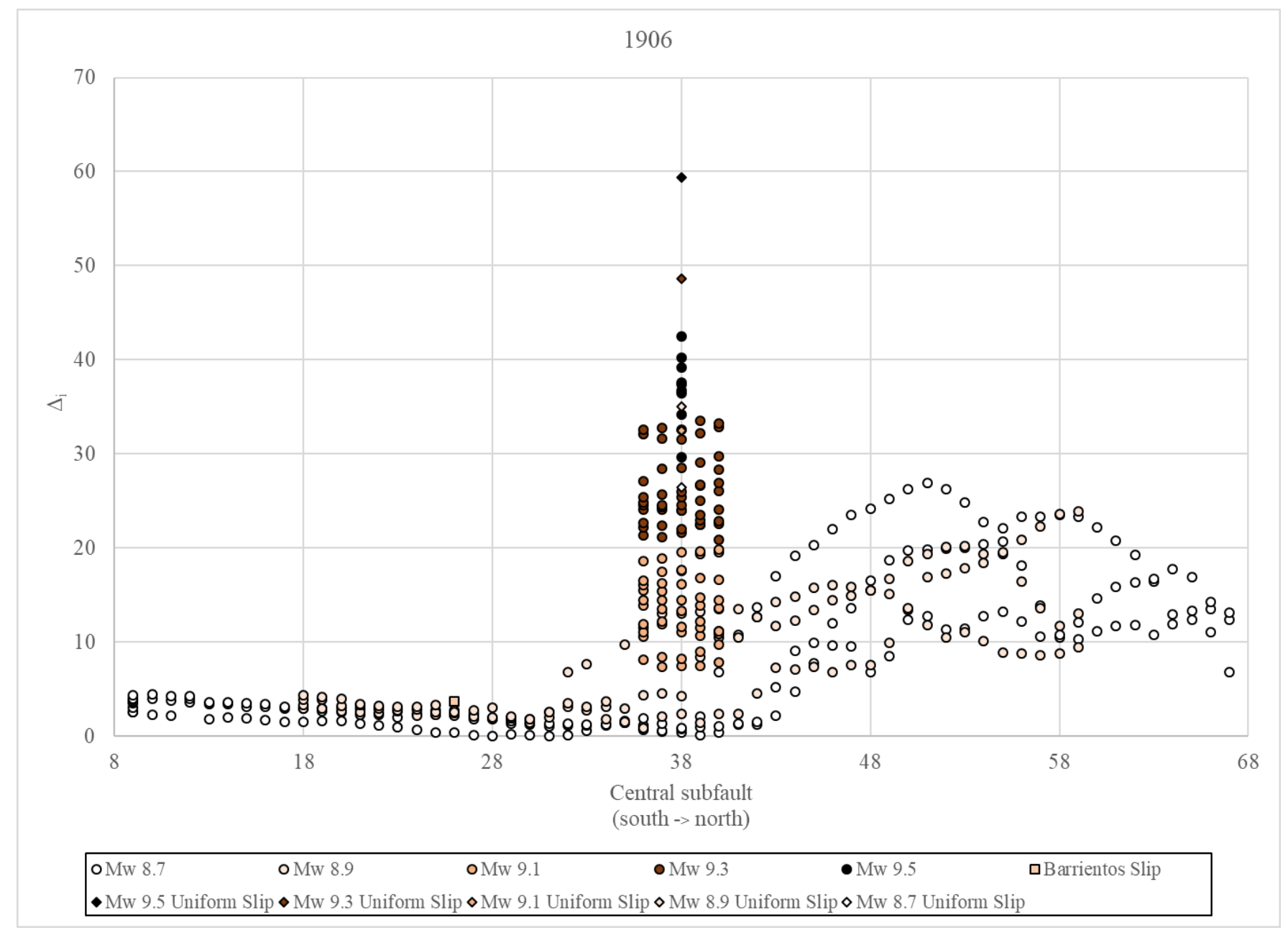

Appendix $E_{12}$ : The $\Delta_{i}$ versus central subfault of rupture for all tsunami simulations relative to the lowest AIC value calculated from observations of the 1906 historical tsunami. Earthquake magnitude positively correlates to darker colored data points. 


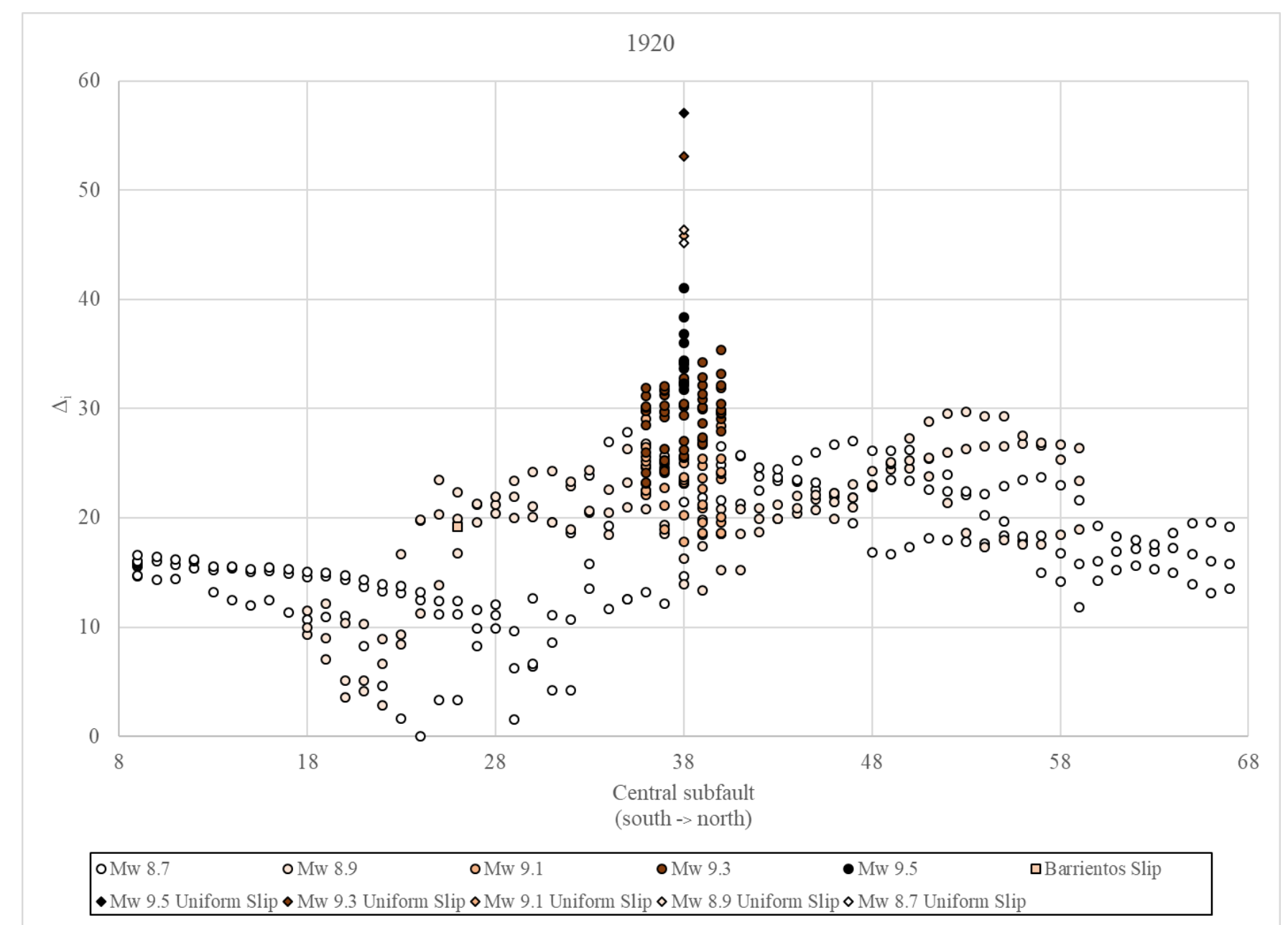

Appendix $E_{13}$ : The $\Delta_{i}$ versus central subfault of rupture for all tsunami simulations relative to the lowest AIC value calculated from observations of the 1920 historical tsunami. Earthquake magnitude positively correlates to darker colored data points 


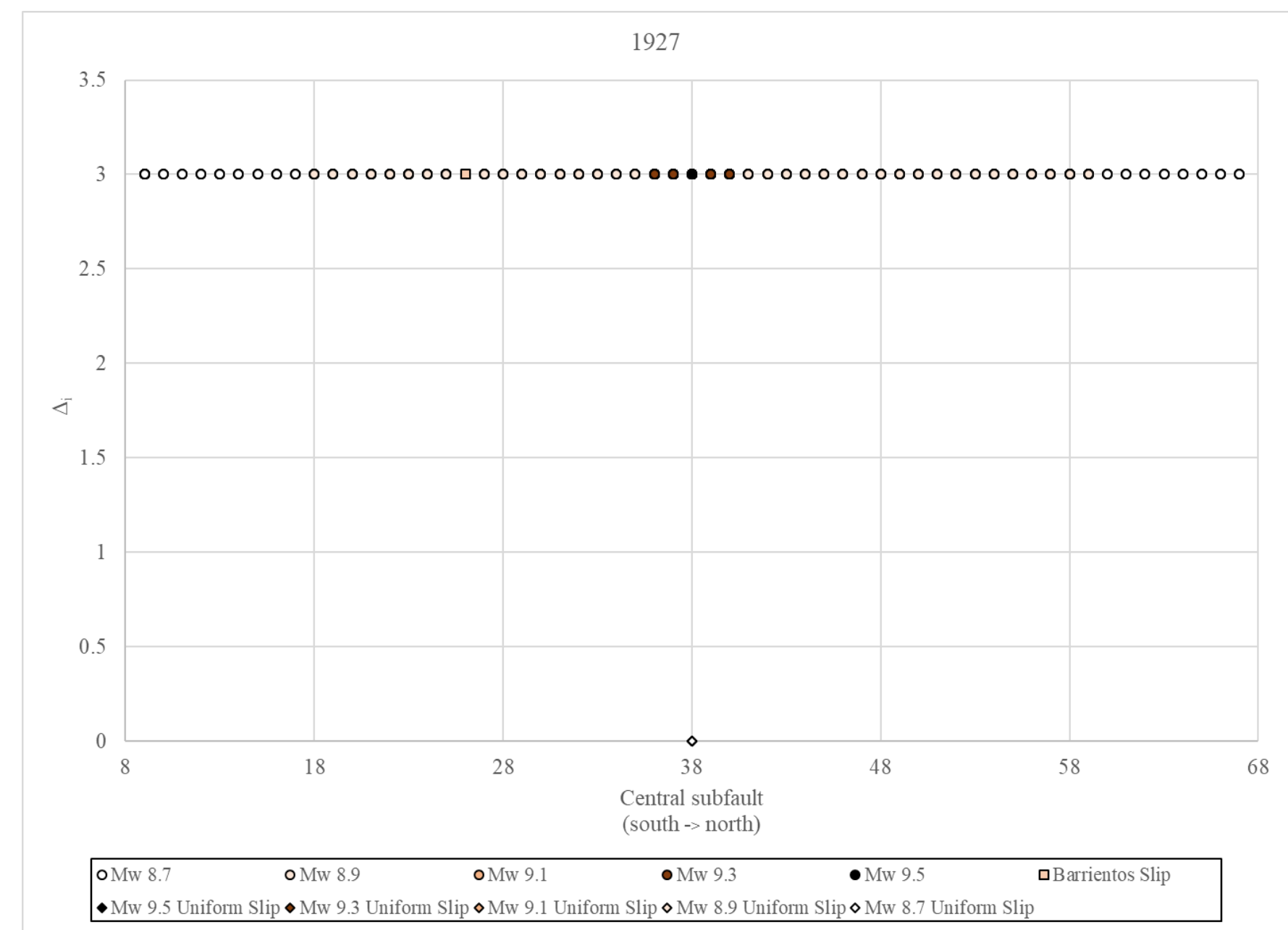

Appendix $\mathrm{E}_{14}$ : The $\Delta_{\mathrm{i}}$ versus central subfault of rupture for all tsunami simulations relative to the lowest AIC value calculated from observations of the 1927 historical tsunami. Earthquake magnitude positively correlates to darker colored data points. 


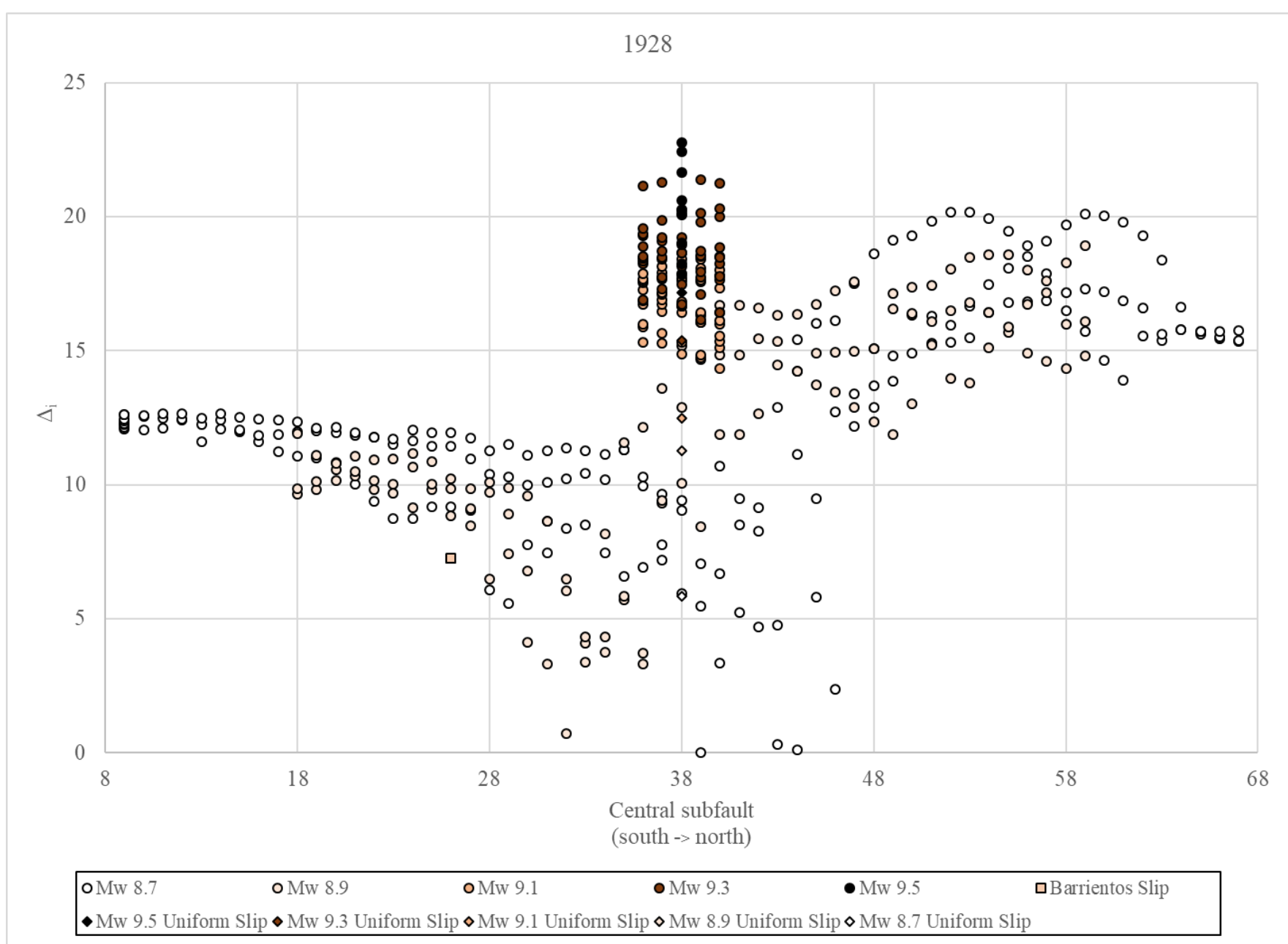

Appendix $\mathrm{E}_{15}$ : The $\Delta_{\mathrm{i}}$ versus central subfault of rupture for all tsunami simulations relative to the lowest AIC value calculated from observations of the 1928 historical tsunami. Earthquake magnitude positively correlates to darker colored data points. 


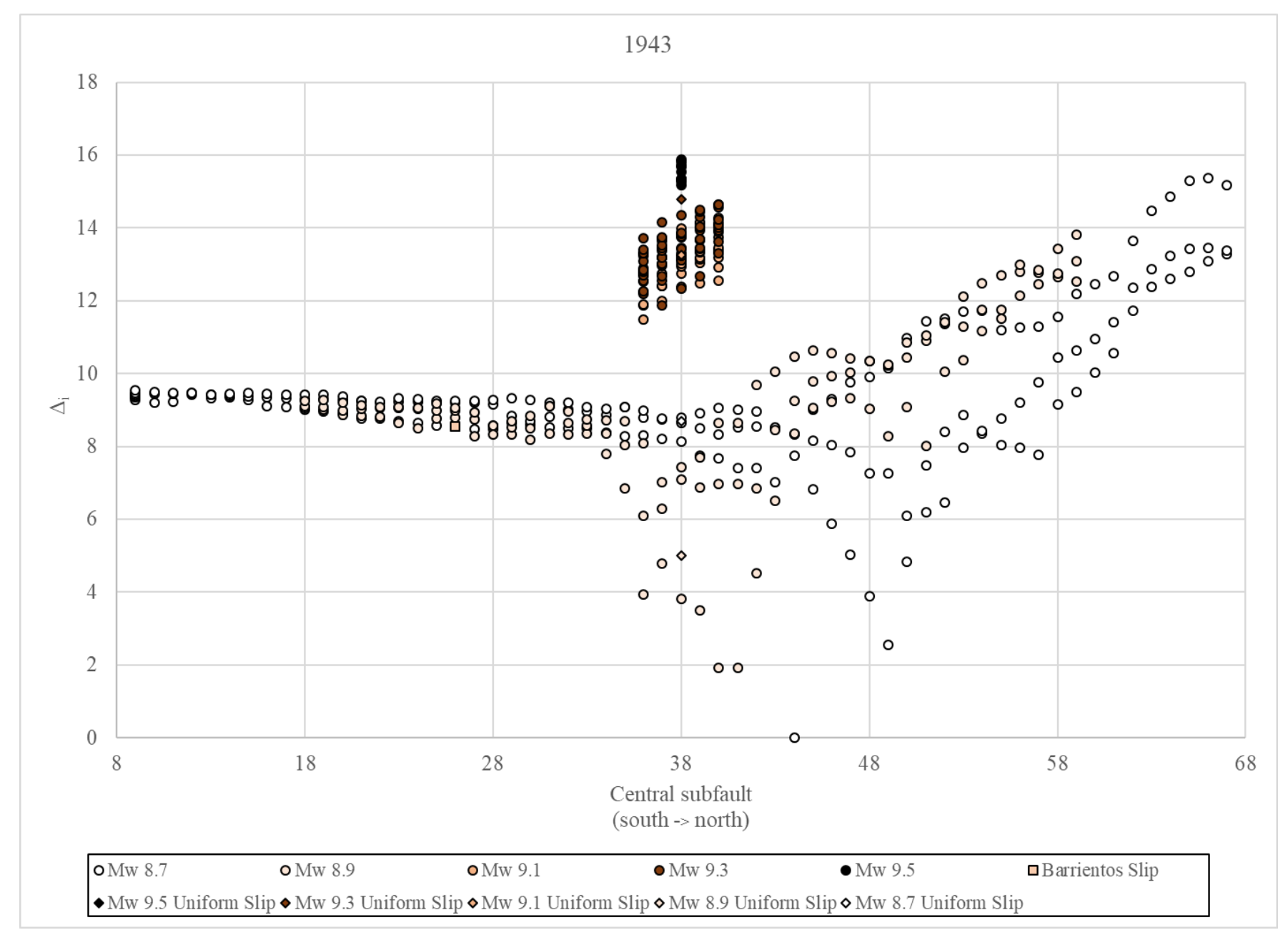

Appendix $\mathrm{E}_{16}$ : The $\Delta_{\mathrm{i}}$ versus central subfault of rupture for all tsunami simulations relative to the lowest AIC value calculated from observations of the 1943 historical tsunami. Earthquake magnitude positively correlates to darker colored data points. 


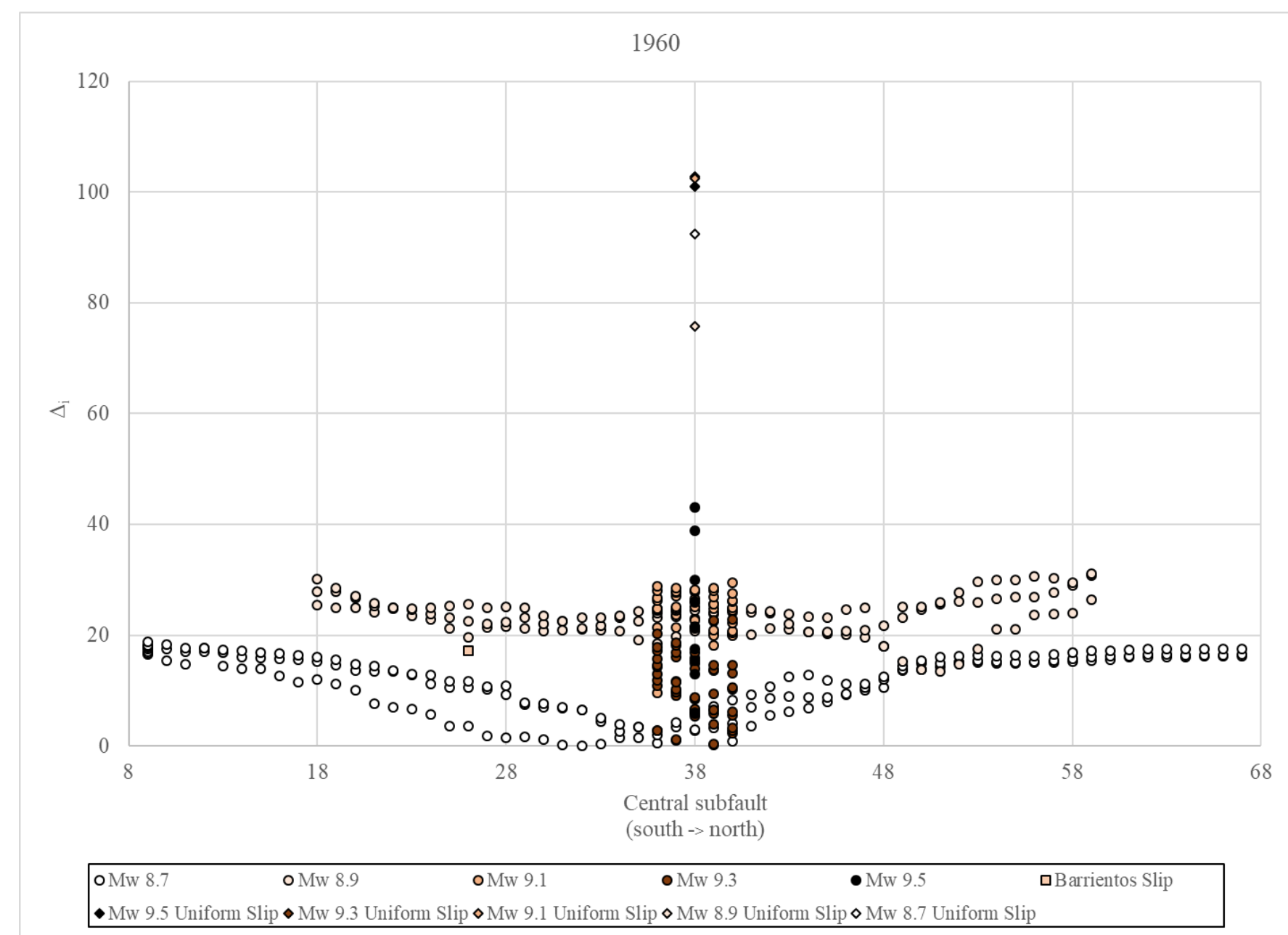

Appendix $\mathrm{E}_{17}$ : The $\Delta_{\mathrm{i}}$ versus central subfault of rupture for all tsunami simulations relative to the lowest AIC value calculated from observations of the 1960 historical tsunami. Earthquake magnitude positively correlates to darker colored data point. 